\title{
Leiding moeten zij hebben : een geschiedenis van de sociaal pedagogische zorg voor mensen met een verstandelijke handicap in Nederland tussen 1900 en 1945
}

Citation for published version (APA):

Brants, L. (2004). Leiding moeten zij hebben : een geschiedenis van de sociaal pedagogische zorg voor mensen met een verstandelijke handicap in Nederland tussen 1900 en 1945. [Doctoral Thesis, Maastricht University]. Garant. https://doi.org/10.26481/dis.20040618lb

Document status and date:

Published: 01/01/2004

DOI:

10.26481/dis.20040618lb

Document Version:

Publisher's PDF, also known as Version of record

Please check the document version of this publication:

- A submitted manuscript is the version of the article upon submission and before peer-review. There can be important differences between the submitted version and the official published version of record. People interested in the research are advised to contact the author for the final version of the publication, or visit the DOI to the publisher's website.

- The final author version and the galley proof are versions of the publication after peer review.

- The final published version features the final layout of the paper including the volume, issue and page numbers.

Link to publication

\footnotetext{
General rights rights.

- You may freely distribute the URL identifying the publication in the public portal. please follow below link for the End User Agreement:

www.umlib.nl/taverne-license

Take down policy

If you believe that this document breaches copyright please contact us at:

repository@maastrichtuniversity.nl

providing details and we will investigate your claim.
}

Copyright and moral rights for the publications made accessible in the public portal are retained by the authors and/or other copyright owners and it is a condition of accessing publications that users recognise and abide by the legal requirements associated with these

- Users may download and print one copy of any publication from the public portal for the purpose of private study or research.

- You may not further distribute the material or use it for any profit-making activity or commercial gain

If the publication is distributed under the terms of Article 25fa of the Dutch Copyright Act, indicated by the "Taverne" license above,

Download date: 26 Apr. 2023 
Leiding moeten zij hebben 
Een handelseditie van dit proefschrift is verschenen bij Garant-Uitgevers te Antwerpen/Apeldoorn ISBN: 90-441-1633-9 


\section{Leiding moeten zij hebben}

Een geschiedenis van de sociaal pedagogische zorg voor mensen met een verstandelijke handicap in Nederland tussen 1900 en 1945

\section{PROEFSCHRIFT}

ter verkrijging van de graad van doctor aan de Universiteit Maastricht, op gezag van de Rector Magnificus, Prof. mr. G.P.M.F. Mols volgens het besluit van het College van Decanen, in het openbaar te verdedigen op vrijdag 18 juni 2004 om 14.00 uur

door

Laurentius Adrianus Petrus Maria Brants 


\section{Promotor:}

Prof. dr. A.T.G. van Gennep

Beoordelingscommissie:

Prof. dr. A.P. Aldenkamp (voorzitter)

Prof. dr. H. Baartman (Vrije Universiteit Amsterdam)

Dr. H. Oosterhuis 


\section{Inhoudsopgave}

\section{Dankwoord 9}

\section{Hoofdstuk 1 Inleiding 11}

1.1 Theoretische uitgangspunten 12

1.2 Doelstelling en vraagstelling 15

1.3 Bronnen 16

1.4 Terminologie 17

1.5 Opzet 18

\section{Hoofdstuk 2 Grondslagen 1900-1917}

2.1 Begripsvorming 19

2.2 Maatschappelijke ontwikkelingen 23

2.3 Ontstaan van het Buitengewoon Lager Onderwijs 25

2.4 Eerste pogingen tot hulpverlening aan oud-leerlingen van het BLO 29

2.4.1 Patronaat 29

2.4.2 Voortgezette opleiding 32

2.4.3 Centrale Vereniging ter Behartiging van de Belangen 33 van Zwakzinnigen

2.4.4 Avondonderwijs 34

2.4.5 Aangepaste arbeid 35

Hoofdstuk 3 Keuze voor professionalisering, Amsterdam 1917-1924 39

3.1 Oud-leerlingen gevolgd 39

3.2 Het after-care rapport 40

3.3 Nazorg in Amsterdam 1921-1922 46

3.4 De nazorg als onderdeel van de geestelijke gezondheidszorg 49

3.5 De Arbeidsschool voor Geestelijk Zwakken 51

Hoofdstuk 4 Programma voor de nazorg, Haarlem 1922-1925 55

4.1 Valse start 55

4.2 Het Haarlemse nazorgrapport 57

4.2.1 Behoefte aan hulp en verzorging 57

4.2.2 Noodzaak van hulp 58

4.2.3 Oplossingen 63
A. Avondonderwijs 63
B. Maatschappelijke hulp 64
C. Verbandscommissie 66
D. Werkinrichting 66
E. Vakopleiding 67

4.3 Reacties op het rapport 68

4.4 Definitieve regeling van de Haarlemse nazorg 70 
Hoofdstuk 5 Nazorg in ontwikkeling 1925-1930 73

5.1 Maatschappelijke omstandigheden in de jaren twintig 73

5.2 Denken over zwakzinnigen 74

5.2.1 BLO en zwakzinnigheid 75

5.2.2 Sociale psychiatrie en zwakzinnigheid 77

5.2.3 Arbeidsvoorziening en zwakzinnigheid 78

5.2.4 Nazorg of internaatszorg 80

5.3 Theorie van de nazorg 85

5.4 Praktijk van de nazorg 90

5.4.1 Groei van de nazorg 90

5.4.2 Financiering van de nazorg 96

5.4.3 Maatschappelijke zorg 99

5.4.4 Werkinrichtingen 106

5.4.5 Avondverzorging 108

5.4.6 Registratie van oud-leerlingen 110

5.5 Invloed van de nazorg op het BLO 110

5.6 Onderling contact van nazorgwerkers 112

Hoofdstuk 6 Tegen de verdrukking in 1931-1940 113

6.1 Maatschappelijke ontwikkelingen 113

6.2 Opvattingen over zwakzinnigen 114

6.2.1 BLO en zwakzinnigheid 115

6.2.2 Sociale psychiatrie en zwakzinnigheid 123

6.2.3 Arbeidsvoorziening en zwakzinnigheid 125

6.2.4 Discussie: zwakzinnigheid en criminaliteit 126

6.3 Ontwikkelingen in de nazorg 131

6.3.1 Groei van de nazorg 131

6.3.2 financiering van de nazorg 134

6.3.3 Ontwikkeling van de praktijk 138

6.4 Samenwerking binnen de nazorg 139

6.5 Relatie met aanverwante hulpvormen 141

6.5.1 Nazorg en BLO 142

6.5.2 Nazorg en sociale psychiatrie 143

6.5.3 Nazorg en arbeidsbemiddeling 146

A. Plaatselijke contacten 146

B. Landelijke contacten 147

6.5.4 Nazorg en beroepskeuze 151

Hoofdstuk 7 Ondanks alles door blijven werken 1940-1945 153

7.1 Tien mei 1940 en daarna 153

7.2 Gelijkschakeling 155

7.3 Arbeidsbemiddeling 156

7.4 Arbeitseinsatz 158

7.5 Een dubieus rapport 160

7.6 Zorgen om zwakzinnigen 162 


\subsubsection{Criminaliteit 162}

7.6.2 Huize Vechtoever 163

7.6.3 Werkkamp voor debielen 164

7.7 Voogdij 167

7.8 Toenemende dreiging: Rotterdam 168

7.9 Oorlog en bevrijding: chaos en opnieuw beginnen 169

Hoofdstuk 8 Discussie en conclusie 171

8.1 Discussie 171

8.1.1 De doelgroep van de nazorg 171

8.1.2 Werkwijzen van de nazorg 173

8.1.3 Nazorg en het denken over zwakzinnigen 16

8.1.4 Nazorg en maatschappelijke ontwikkelingen 177
A. De verzuiling 177
B. Economische crisis 178
C. De bezetting 179

8.1.5 Nazorg en BLO 179

8.1.6 Nazorg en aanverwante hulpvormen 180

8.2 Conclusie: maatschappelijke integratie van oud-leerlingen van het BLO 183

Noten 188

Lijst van gebruikte afkortingen 209

Bronnen en literatuur 210

Register van personen 229

Summary 231 



\section{Dankwoord}

Toen ik in 1992 met de voorbereidende werkzaamheden van dit proefschrift begon, kon ik niet vermoeden dat het mij 12 jaar zou kosten om deze studie te voltooien. Ernstige ziektes en verschillende drukke banen zorgden voor langdurige onderbrekingen in het werk. Uiteindelijk is het er dan toch van gekomen, niet in het minst door de bereidheid van mijn promotor, prof. dr. A.T. G. van Gennep, mij ondanks alle onderbrekingen te blijven begeleiden. Ik wil hem dan ook hierbij hartelijk danken voor het geduld, de wijsheid en het inzicht waarmee hij mij al die jaren begeleid heeft. Ook prof. dr. H.E.M. Baartman wil ik hierbij speciaal vernoemen. Aanvankelijk was het de bedoeling dat hij als copromotor zou optreden, maar door de vele onderbrekingen van het onderzoekswerk is het daarvan uiteindelijk niet gekomen. Daarom ben ik erg blij, dat hij ondanks alles toch bereid was om toe te treden tot de beoordelingsommissie. De discussies met hem en de opmerkingen die hij maakte zijn voor mij erg inspirerend geweest.

Verder wil ik de overige leden van de beoordelingscommissie, prof. dr. Aldenkamp, voorzitter en dr. H. Oosterhuis bedanken voor hun bereidheid, mijn dissertatie te beoordelen.

Omdat ik deze dissertatie in betrekkelijke eenzaamheid heb geschreven - ik was immers niet verbonden aan enig wetenschappelijk instituut - wil ik hier ook de leden van de voormalige 'Studiegroep Geschiedenis van de Zwakzinnigenzorg' van het Trimbos-instituut in Utrecht bedanken, die voor mij door de jaren heen een anker zijn geweest om door te gaan met het onderzoekswerk. Vooral wil ik Inge Mans noemen, maar ook Theo Jak, Dorien Graas en Annemieke Klijn. De discussies in de werkgroep hebben mij zeer geholpen met het schrijven van dit proefschrift.

Verder wil ik alle mensen bedanken die mij hebben geholpen bij het schrijven van dit proefschrift. Allereerst de heer M. Princen, oud-directeur van de 'Stichting Jan Baptist' in Maastricht, die mij toegang verschafte tot het rijke archief van deze organisatie en verder alle medewerkers van de verschillende Rijks-, Regionale en Gemeentearchieven en bibliotheken die mij door de jaren heen geholpen hebben.

Belangrijkste steun in de jaren dat ik aan dit proefschrift heb gewerkt was mijn echtgenoot, Mart de Corte, die heel wat avonden alleen heeft moeten doorkomen als ik weer achter de computer zat. Uiteindelijk is het er dan toch van gekomen.

Ik wil deze dissertatie aan twee bijzondere personen opdragen. Allereerst aan Pier de Boer, de eerste nazorgambtenaar in Nederland en de min of meer vergeten pionier van het sociaal-pedagogisch werk in Nederland. Dit proefschrift is mede bedoeld om de aandacht te vestigen op de zeer belangrijke rol die hij op dit gebied heeft gespeeld. Mijns inziens is een belangrijk deel van zijn inzichten en ideeën nog steeds actueel voor de zorg voor mensen met een verstandelijke handicap in de maatschappij van dit moment. Daarnaast draag ik dit proefschrift op aan Kees Coolen, mijn oudoom. Geboren in 1922 behoorde 
hij tot de doelgroep van de nazorg. Toch heeft hij nooit enig contact gehad met welke organisatie voor de ondersteuning van mensen met een verstandelijke handicap dan ook. Door de inzet van zijn moeder, mijn overgrootmoeder, en zijn zuster, mijn grootmoeder, heeft hij altijd in de 'vrije maatschappij' kunnen wonen en werken, in zijn eigen bekende sociale omgeving waarin hij een geheel eigen rol speelde en dat nog steeds doet. 


\section{"Geen Amsterdamse debielen voor hun opvoeding naar de Achterhoek"}

Pier de Boer, nazorgambtenaar te Amsterdam ${ }^{1}$

De begeleiding van mensen met een verstandelijke handicap in de maatschappij, zoals die vandaag de dag door MEE, tot voor kort de Sociaal-Pedagogische Diensten (SPD's) wordt uitgevoerd, kent een lange voorgeschiedenis. Aan het begin van de twintigste eeuw werden de eerste pogingen gedaan, deze begeleiding vorm te geven. Deze pogingen waren nauw verbonden met een speciale vorm van onderwijs voor kinderen die in het gewone onderwijs niet mee konden komen.

Het Nederlandse onderwijs werd aan het einde van de negentiende eeuw steeds meer gestandaardiseerd. Een vastgestelde hoeveelheid lesstof werd klassikaal aangeboden in periodes van één jaar. Door dit leerstofjaarklassensysteem werden verschillen in de snelheid van het opnemen van de lesstof erg duidelijk gemaakt. Kinderen die hierin niet goed mee konden komen vielen in negatieve zin op. Ze werden als een last beschouwd, zowel voor hun sneller lerende klasgenootjes als voor de leerkrachten. Tot 1901 hoefde dat niet zo'n groot probleem te zijn, want tot dat jaar was het mogelijk om lastige kinderen van school te verwijderen. Maar toen op één januari 1901 de Leerplichtwet van kracht werd, verviel deze mogelijkheid en werd het probleem groter. ${ }^{2}$

$\mathrm{Al}$ aan het einde van de negentiende eeuw was deze groep kinderen geclassificeerd als achterlijk. Er werd geprobeerd voor deze groep een oplossing te verzinnen zonder hen van onderwijs uit te sluiten of het onderwijssysteem te veranderen. Dat leidde tot proeven met vormen van apart onderwijs, eerst in afzonderlijke klassen, later in speciale scholen. Zo kon het reguliere onderwijs worden ontlast en kregen achterlijke kinderen onderwijs dat zoveel mogelijk aan hun capaciteiten was aangepast. Het was de nadrukkelijke bedoeling dat zij geschikt gemaakt werden voor een zelfstandig bestaan in de maatschappij nadat zij de school hadden doorlopen. Deze nieuwe onderwijsvorm, die uiteindelijk Buitengewoon Lager Onderwijs (BLO) zou worden genoemd, sloeg aan en maakte in de eerste helft van de twintigste eeuw een stormachtige ontwikkeling door. ${ }^{3}$

De maatschappij stond aan het begin van de twintigste eeuw zeker niet positief tegenover de leerlingen van de scholen voor BLO, die uiteindelijk als zwakzinnig zouden worden geclassificeerd. Aan zwakzinnigheid, en dan ging het vooral om de lichtere vormen ervan, waren veel negatieve connotaties verbonden. Die kwamen er in het kort op neer, dat lichtzwakzinnigen door hun aard geneigd zouden zijn te vervallen tot zaken als vagebondisme, prostitutie en criminaliteit. Verder zouden zwakzinnigen, doordat zij zich sneller voortplantten dan normale mensen, bijdragen aan de degeneratie van de bevolking als geheel.

Sommigen vonden het gevaar dat van zwakzinnigen uitging zó groot, dat zij er voor pleitten hen uit de samenleving te verwijderen en in gestichten en kolonies onder te brengen, zodat zij de maatschappij geen schade meer zouden kunnen 
toebrengen. Anderen, onder hen de meeste betrokkenen bij het Buitengewoon Lager Onderwijs, vonden dat zwakzinnigheid een risico voor de samenleving inhield, maar niet in die mate dat segregatie noodzakelijk was. Met de juiste pedagogische benadering zou dat risico kunnen worden beperkt en beheerst. Aanvankelijk dacht men dat aangepast onderwijs volstond om de integratie van (licht)zwakzinnigen in de samenleving mogelijk te maken. In de praktijk, toen de eerste leerlingen het BLO gingen verlaten, bleek echter dat zij ook daarna nog hulp en steun nodig hadden om zich in de maatschappij te kunnen handhaven. Vanaf 1905 werden er pogingen ondernomen om deze hulp en steun in georganiseerd verband te bieden. Sprak men aanvankelijk nog van maatschappelijke hulp, later noemde men deze hulp nazorg $B L O$ of, nog korter, nazorg.

\subsection{Theoretische uitgangspunten}

Voor deze dissertatie hanteer ik als belangrijkste perspectief om naar de ontwikkeling van de ambulante zorg voor mensen met een lichte verstandelijke handicap te kijken het perspectief van de civilisatietheorie zoals Norbert Elias die in de jaren dertig ontwikkelde. ${ }^{4}$ Kort samengevat komt deze theorie er op neer dat in de westerse wereld vanaf de middeleeuwen een proces gaande is waarbij alledaagse lichamelijke activiteiten met betrekking tot zaken als ontlasting, eetgedrag en seksualiteit steeds verdergaand worden gereglementeerd en geprivatiseerd. Elites, aanvankelijk de adel, later ook steeds meer groepen uit de burgerij, gebruikten deze regels als een middel om zich van het gewone volk te kunnen onderscheiden. Door het voorgeschreven gedrag te vertonen konden zij laten zien dat zij tot de elite behoorden. Dat had belangrijke gevolgen. Steeds meer groepen in de samenleving gingen deze regels overnemen om zo op z'n minst de schijn te wekken dat zij tot de elite behoorden. Het gevolg was, dat de oorspronkelijke elites steeds meer en ingewikkelder regels gingen ontwikkelen, die steeds grotere delen van het leven besloegen om zich daardoor van de lagere sociale klassen te kunnen blijven onderscheiden.

In de loop van de negentiende eeuw voltrok zich een belangrijke verandering in dit civilisatieproces. In deze periode namen grotere groepen uit de burgerij de gedragsregels van de elite over, het proces 'democratiseerde' als het ware. Tegelijkertijd bleken deze nieuwe middengroepen niet langer te accepteren dat leden van de laagste sociale klassen zich aan deze regels onttrokken. Gedrag dat oorspronkelijk als wenselijk werd voorgeschreven zou uiteindelijk dwingend worden opgelegd. $^{5}$

Dit proces is goed te illustreren aan de hand van de ontwikkeling van de armenzorg. Deze was vanaf de middeleeuwen 'waardevrij' geweest: aan de ontvangers van hulp werden geen andere eisen gesteld dan dat zij arm waren en behoeftig, indachtig de uitspraak van Christus, dat de armen er altijd zouden zijn. Geven aan de armen was een manier om in het hiernamaals beter terecht te komen. Vanaf het einde van de achttiende eeuw kwam er in de progressieve burgerij steeds meer kritiek op deze manier van hulpverlening. Men vond dat er aan armen eisen moesten worden gesteld om hulp te kunnen ontvangen. Armenzorg moest gebruikt worden om hen te leren zich aan de burgerlijke gedragsregels te houden, vooral met betrekking tot arbeid. Armen moesten leren bij te dragen aan het welzijn van de 
maatschappij als geheel en verder geen aanstoot te geven. Zeker in de negentiende eeuw ontstonden er in Nederland tientallen, zoniet honderden organisaties waarin goedwillende burgers probeerden hun minder fortuinlijke medemens te verheffen naar een hoger plan. ${ }^{6}$

Belangrijk hierbij waren de veranderingen die zich in de economie voltrokken. Deze werd door de industrialisering steeds meer fabrieksmatig van aard. Daarnaast voltrok zich een verandering in de opvattingen over het verrichten van arbeid:

deze verschoof van 'taakoriëntatie' naar 'tijdoriëntatie'. Het arbeidsritme werd niet langer bepaald door de vraag of een taak voltooid was maar voorgeschreven door de klok: er moest per dag een vastgestelde hoeveelheid tijd gewerkt worden. ${ }^{7} \mathrm{Om}$ aan deze nieuwe eisen te kunnen voldoen, moesten arbeiders wél voldoende discipline opbrengen om zich aan de klok te houden en thuis een voldoende ordelijk leven leiden. Daarbij speelde het idee dat een samenleving het zich niet kon veroorloven om grote groepen ongeciviliseerde paupers te onderhouden zeker een rol. ${ }^{8} \mathrm{De}$ paupers moesten beschaafd worden, geleerd om zich aan de nieuwe arbeidsmethoden te houden en zich zonder al te veel overlast in te passen in de nieuwe dichtbevolkte industriecentra die in de loop van de negentiende eeuw ontstonden.

Tot de elites die hun moraal wilden overbrengen op de lagere standen behoorden al vrij snel na haar ontstaan aan het einde van de negentiende eeuw ook de sociaal-democratische beweging. Binnen de arbeidersklasse deed zich eveneens een proces van elitevorming voor, ${ }^{9}$ waarbij werken op geregelde tijden, in loondienst, tegen een salaris waarmee één persoon een gezin kon onderhouden, de norm was geworden. Degenen die zich aan deze norm hielden, beschouwden zich als superieur aan de mensen die hieraan niet voldeden en die door Marx al in 1848 het 'Lumpenproletariat' waren genoemd. ${ }^{10}$

Rond de overgang van de negentiende naar de twintigste eeuw leidde de toenemende zorg over mensen die zich niet aan de heersende moraal hielden tot een belangrijke omslag in het denken over de rol van de overheid. Langzaamaan ontstond het idee, dat de overheid het recht had om sociaal gewenst gedrag bij haar burgers af te dwingen. Er ontstond draagvlak voor diepgaand ingrijpen in het privéleven van sociale afwijkelingen, van mensen die zich niet konden of wilden houden aan de heersende gedragsregels. ${ }^{11}$ Het leidde tot een stelsel van regels en wetten waarmee de overheid de moraal van de burgerlijke elites dwingend kon opleggen aan degenen die er zich niet aan hielden.

In het denken over de wijze waarop dat sociaal gewenste gedrag moest worden opgelegd, tekenden zich in deze periode twee stromingen af. Aan de ene kant stonden diegenen, die vonden dat de overheid het recht moest krijgen om in te grijpen in de levens van haar burgers om door middel van (gedwongen) behandeling sociale problematiek tegen te gaan. Deze sociaalhygiënisten geloofden in de kracht van therapie. Mensen die sociaal ongewenst gedrag vertoonden zouden genezen kunnen worden. Er ontstond in Nederland, net zoals overigens in de gehele westerse wereld, een stelsel van min of meer onvrijwillige hulpverlening dat door Donzelot "la police des familles" ${ }^{12}$, de gezinspolitie, werd genoemd. Er ontstonden voor verschillende groepen afwijkelingen 'verzorgingsarrangementen' (waartoe de ambulante zorg voor mensen met een verstandelijke handicap ook gerekend kan 
worden), waarmee geprobeerd werd personen die zich niet aan de sociale regels hielden goedschiks dan wel kwaadschiks in het gareel te brengen. ${ }^{13}$

Aan de andere kant stond een deel van de burgerlijke elites, dat deze al dan niet gedwongen hulpverlening nutteloos vond. Deze eugenetici gingen er van uit, dat gedrag erfelijk bepaald was en daardoor onveranderlijk. Mensen met een slechte erfelijke aanleg waren daardoor niet vatbaar voor therapie en, erger nog, zij zouden zich sneller voortplanten dan mensen met een goede erfelijke aanleg, waardoor de 'goeden' uiteindelijk getalsmatig door de 'slechten'overvleugeld zouden worden. De enige mogelijke oplossingen die de aanhangers van de eugenetiek voor sociale problematiek zagen was, aan de ene kant, het isoleren van sociale afwijkelingen uit de samenleving om aan de bestaande problematiek een einde te maken en aan de andere kant het ingrijpen in de menselijke voortplanting om toekomstige problematiek te voorkomen.

Paradoxaal genoeg vond de eugenetiek haar oorsprong in hetzelfde vooruitgangsgeloof als het sociaalhygiënisme. Beide stromingen gingen er vanuit dat de (medische) wetenschap in staat was om oplossingen te geven voor sociale problematiek. In het geval van het sociaalhygiënisme leidde dat tot het geloof in de kracht van therapie en begeleiding, in het geval van de eugenetiek in het geloof dat door het nemen van eugenetische maatregelen sociale probleemgevallen uit de maatschappij verwijderd konden worden.

Het denken over de invloed van de erfelijkheid op sociale problematiek was aan het einde van de negentiende en het begin van de twintigste eeuw uiterst modern. Er werd in brede kring over nagedacht en de bereidwilligheid om de invloed van erfelijkheid op menselijk gedrag te accepteren was groot. In deze zin was het geloof in eugenetische principes groot. Veel minder groot was de bereidheid te geloven in de allesoverheersende macht van de erfelijkheid, waardoor elke poging om menselijk gedrag te veranderen nutteloos zou zijn. Daarvoor was de sfeer in de hulpverlenende gemeenschap, in de hoogtijdagen van het positivisme, véél te optimistisch. Er was eenvoudigweg geen ruimte voor een in hoofdzaak pessimistische theorie die geen ruimte liet voor het idee van de 'maakbaarheid van de samenleving'. En er was al helemaal weinig steun voor de maatregelen die de eugenetici voorstelden met betrekking tot het ingrijpen in de voortplanting. De overheid mocht dan wel diep ingrijpen in de privé-levens van haar burgers, ingrijpen in het recht op voortplanting was voor het overgrote deel van de hulpverlenende gemeenschap een stap te ver. Ook op politiek gebied kregen de eugenetici geen steun. Geen enkele van de door hen voorgestelde maatregelen werd in Nederland ingevoerd. Dat mag opmerkelijk heten, want in grote delen van de westerse wereld kwam het wél tot eugenetisch getinte wetgeving, onder andere in grote delen van de Verenigde Staten, de Scandinavische landen en Duitsland. Een belangrijke rol speelde daarbij de verschillende christelijke levensbeschouwelijke groepen, die in politiek opzicht een sleutelrol in Nederland speelden en ingrijpen in de menselijke voortplanting op theologische gronden afwezen.

I $\mathrm{k}$ wil het ontstaan van de ambulante zorg voor mensen met een verstandelijke handicap zien in het perspectief van de civilisatietheorie van Elias en tegen de achtergrond van het spanningsveld tussen sociaal-hygiënisme en eugenetiek. 
Aan de ambulante zorg voor mensen met een verstandelijke handicap zat zeker een disciplineringsaspect, maar het zou van eenzijdigheid getuigen om alleen dat aspect te willen zien. Bij de personen die de hulp opzetten en uitvoerden speelde zeker ook de oprechte zorg over wat er met de oud-leerlingen van het BLO zou gebeuren, als zij zonder begeleiding de maatschappij ingestuurd zouden worden. Ik ruim dan ook zeker plaats in voor de rol van individuen, die grote invloed hebben gehad op de ontwikkeling van de zorg voor oud-leerlingen van het BLO. In deze zin ben ik het eens met Anton Blok, als hij stelt dat

\begin{abstract}
"... mensen gevangen [zijn] in bredere kaders, ruimtelijke en maatschappelijke structuren, of hoe men de figuraties die mensen met elkaar vormen ook wil noemen. Maar diezelfde kaders bieden ook speelruimte - niet in het minste omdat ze zelf in beweging zijn. Voor de een is de speelruimte ongetwijfeld groter dan voor de ander, maar er zijn (...) altijd mogelijkheden voor wendbaarheid, verzet en verandering." ${ }^{14}$
\end{abstract}

In deze dissertatie zal ik nadrukkelijk ingaan op de manier waarop de betrokkenen bij de nazorg gebruik maakten van de kaders waarin zij leefden en werkten.

\title{
1.2 Doelstelling en vraagstelling
}

Het doel van dit onderzoek is om de geschiedenis van de nazorg te beschrijven, vanaf het ontstaan van het BLO aan het einde van de negentiende eeuw tot aan de bevrijding na de Duitse bezetting in 1945. De hoofdvraag is: in hoeverre droeg de nazorg bij aan de integratie van lichtzwakzinnigen in de Nederlandse samenleving? Daarbij is het in eerste instantie belangrijk vast te stellen, wat ik onder integratie versta. Daarbij ga ik uit van de doelstelling die de nazorg zichzelf stelde. Nazorgwerkers gebruikten de term 'integratie' zelf niet: zij spraken over handhaving van hun pupillen in het eigen sociale milieu, in hun eigen veilige sociale omgeving waar zij mensen kenden en zelf gekend werden: familie, buurtgenoten en collega's die het belangrijkste sociale kader vormden waarbinnen de zwakzinnige leefde. Het ging dus in eerste instantie om het behouden van een al gegeven situatie, in plaats van het bewerkstelligen van een nieuwe.

De vraag, in hoeverre nazorgwerkers hun doelstelling haalden, kan vervolgens op twee wijzen worden beantwoord. Allereerst cijfermatig: hoeveel pupillen van de nazorg konden zich in de maatschappij handhaven en hoeveel moesten in een inrichting worden opgenomen. Ten tweede kan deze vraag ook worden beantwoord door in te gaan op de manier, waarop de nazorg het denken over zwakzinnigen beïnvloedde, in hoeverre de nazorgwerkers in staat waren om de maatschappelijke kaders met betrekking tot zwakzinnigen te doen verschuiven, zoals Blok in bovenstaand citaat bedoelde.

Om deze hoofdvraag volledig te kunnen beantwoorden, stel ik ook een aantal deelvragen, die als een verbijzondering van de hoofdvraag te beschouwen zijn. Zij zijn vooral gericht op de vraag, hoe de nazorg zich ontwikkelde binnen en in wisselwerking met de toenmalige maatschappij, meer specifiek met de hulpverlenende gemeenschap daarbinnen. De eerste deelvraag is: hoe zag de doelgroep van de nazorg eruit en welke verschillende subgroepen werden hierbinnen door de nazorg onderscheiden? Ten tweede wil ik weten: welke werkwijzen hanteerde de nazorg en welke ontwikkeling deed zich daar in de loop van de tijd voor? De derde 
deelvraag luidt: hoe werd er binnen de nazorg over zwakzinnigen en zwakzinnigheid gedacht en hoe verhield zich dat tot het denken over zwakzinnigheid in het algemeen? Als vierde punt wil ik weten: hoe verhield de ontwikkeling van de nazorg zich tot de belangrijke maatschappelijke ontwikkelingen zoals die zich in de onderzoeksperiode voordeden? Ten vijfde stel ik de vraag: hoe was de bijzondere relatie tussen de nazorg en het buitengewoon onderwijs en hoe ontwikkelde deze zich gedurende de onderzoeksperiode? De zesde onderzoeksvraag luidt: wat was de verhouding van de nazorg tot andere hulpvormen die, geheel of gedeeltelijk, op hetzelfde werkterrein actief waren?

De laatste jaren is de beschrijving van de geschiedenis van de zorg voor mensen met een verstandelijke handicap langzaam op gang gekomen. De werkgroep Geschiedenis van de Zwakzinnigenzorg van het Trimbos-instituut, onder bezielende leiding van Inge Mans, was in de jaren negentig het belangrijkste uitwisselingspunt op dit gebied. Aan de werken, die in de loop der tijd door de deelnemers aan deze werkgroep zijn geschreven, heb ik veel gegevens voor mijn eigen onderzoek kunnen ontlenen. Theo Jak schreef Armen van Geest (1988) en Huizen van Barmhartigheid (1883) over de protestants-christelijke residentiële zorg in de negentiende en het begin van de twintigste eeuw. Annemieke Klijn ging in Tussen Caritas en Psychiatrie (1995) in op de ontwikkelingen in de katholiek residentiële zorg tussen 1850 en 1950. Met Zorgenkinderen op School (1996) beschreef Dorien Graas de ontwikkelingen binnen het Buitengewoon Lager Onderwijs in de eerste helft van de twintigste eeuw. Inge Mans, tenslotte, gaf in Zin der Zotheid (1998) een overzicht van de verschillende manieren waarop in de westerse cultuur vanaf de middeleeuwen tot aan het einde van de twintigste eeuw tegen zwakzinnigen is aangekeken.

\subsection{Bronnen}

Het bronnenmateriaal dat ik voor dit onderzoek heb geraadpleegd was erg divers van aard. De belangrijkste bron van materiaal was het archiefonderzoek, dat ik tussen 1992 en 2001 heb verricht in verschillende archieven. De gegevens van de diverse plaatselijke nazorginstellingen waren in hoofdzaak uit deze bron afkomstig. Het meeste archiefmateriaal over de nazorginstellingen is ondergebracht bij de gemeentearchieven van de plaatsen waarin zij actief waren.

Deze vorm van intensief onderzoek heb ik niet naar alle nazorginstellingen die vóór 1945 zijn ontstaan gedaan. Ik heb dat alleen gedaan bij de nazorginstellingen die vóór 1930 zijn opgericht of waar voor die tijd nazorgactiviteiten plaatsvonden, te weten Amsterdam, Arnhem, Breda, Delft, Dordrecht, Den Haag, Haarlem, Rotterdam,

Utrecht en Vlaardingen. De enige uitzondering hierop vormt Groningen, dat in de landelijke ontwikkeling van de nazorg slechts een marginale rol heeft gespeeld en waarover een uitstekende secundaire bron beschikbaar was. ${ }^{15}$ Van de instellingen die tussen 1930 en 1945 ontstonden heb ik er twee nader onderzocht, te weten Maastricht en Zwolle. Naast de beschikbaarheid van archiefmateriaal speelde bij de keuze van deze beide plaatsen ook de excentrische ligging in Nederland een rol, zodat ik mij een beeld van de ontwikkeling van de nazorg buiten de randstad kon vormen. 
Niet van alle nazorginstellingen is het volledige archief bewaard gebleven. In Arnhem en Rotterdam is door oorlogshandelingen veel materiaal verloren gedaan, in Breda, Den Haag en Vlaardingen is maar weinig informatie over de nazorg bewaard gebleven. In Amsterdam, Dordrecht, Haarlem, Maastricht, Utrecht en Zwolle was daarentegen veel over de nazorg terug te vinden. Daarbij moet als bijzonderheid nog worden aangetekend, dat het bijzonder rijke archiefmateriaal van de Maastrichtse nazorg nog aanwezig was bij de rechtsopvolger van de oorspronkelijke instelling, de Stichting Jan Baptist in Maastricht.

Wat betreft de landelijke samenwerking van nazorginstellingen vormde het archief van de Nederlandsche Vereeniging Nazorg Buitengewoon Onderwijs, dat in het gemeentearchief van Amsterdam is ondergebracht, een belangrijke bron. Alle notulenschriften van de vergaderingen van deze vereniging vanaf de oprichting tot aan het einde van de bezetting zijn bewaard gebleven en vormden een rijke bron van informatie.

Een andere belangrijke bron bestond uit een groot aantal artikelen in tijdschriften die met zwakzinnigen, buitengewoon lager onderwijs, psychiatrie en nazorg te maken hadden en die tussen 1900 en 1945 verschenen zijn. Ik heb alle nummers van het Tijdschrift voor Zwakzinnigenzorg, PAIS, het Tijdschrift voor Buitengewoon Onderwijs en het Tijdschrift voor R.K. BLO doorgenomen. Het ging daarbij niet alleen om inhoudelijke artikelen over zwakzinnigen en zwakzinnigheid. De wijze waarop de nazorg zich in verschillende plaatsen in het land ontwikkelde liet zich deels reconstrueren door artikeltjes in rubrieken met namen als $\mathrm{Be}$ richten en Mededeelingen, Van het Hoofdbestuur en Boek en Tijdschrift.

Van tijdschriften als de Psychiatrische en Neurologische Bladen, het Tijdschrift voor Armwezen, Maatschappelijke Hulp en Kinderbescherming en Jeugden Beroep heb ik artikelen doorgenomen als die in het overige bronnenmateriaal werden aangehaald.

Belangrijk waren verder veel afzonderlijke publicaties over zwakzinnigheid, zwakzinnigenzorg en nazorg, die tussen 1900 en 1945 verschenen zijn, in de vorm van boeken, brochures en congresverslagen. Ik heb zeer veel Nederlandse literatuur over dit onderwerp onder ogen gehad.

\subsection{Terminologie}

Ik zal in deze studie de terminologie hanteren zoals die in de periode die mijn onderzoek bestrijkt, de eerste helft van de twintigste eeuw, gebruikelijk was. Ik heb daarvoor gekozen omdat de huidige en toenmalige termen in betekenis niet geheel met elkaar overeenkomen. Aan de term zwakzinnigheid waren aan het begin van de twintigste eeuw heel andere connotaties verbonden dan aan de term mensen met een verstandelijke handicap nu. Daarom zal ik, als het om mensen met een verstandelijke handicap gaat, over zwakzinnigen spreken. Om nog preciezer te zijn zal ik, als het specifiek gaat om de doelgroep van de nazorg, vooral spreken over oudleerlingen van het $B L O$. Dat doe ik omdat er aanwijzingen zijn dat mensen die in de eerste helft van de twintigste als zwakzinnig werden geclassificeerd, nu niet meer als verstandelijk gehandicapt zouden worden beschouwd.

Ik zal ook andere destijds gebruikelijke aanduidingen uit de terminologie rondom zwakzinnigheid gebruiken. Ik zal spreken over idioten, imbecillen en de- 
bielen om mensen aan te duiden met respectievelijk een ernstige, een matige en een lichte verstandelijke handicap, omdat deze termen destijds algemeen gebruikt en geaccepteerd waren. Ook termen als geestelijk minderwaardigen, onvolwaardigen, psychopathen en krankzinnigen zullen de revue passeren.

\subsection{Opzet}

In het tweede hoofdstuk ga ik allereerst in op de begripsvorming rondom zwakzinnigheid en buitengewoon lager onderwijs bij de overgang van de negentiende naar de twintigste eeuw. Ik behandel het ontstaan van het BLO en geef een beschrijving van de vroegste pogingen om de zorg voor oud-leerlingen van het BLO vorm te geven.

Het derde hoofdstuk handelt over de ontstaansgeschiedenis van de eerste professionele nazorg in Amsterdam en de eerste jaren van haar activiteiten, van 1917 tot halverwege de jaren twintig.

In het vierde hoofdstuk ga ik in op het ontstaan van de professionele nazorg in Haarlem. Dat gebeurt aan de hand van een spraakmakend rapport uit 1924, waarop ik uitgebreid zal ingaan. Ik ga verder in op de eerste jaren dat de nazorg in deze stad bestond. Ik bestrijk in dit hoofdstuk de periode 1922-1926.

Het vijfde hoofdstuk behandelt de ontwikkeling van de nazorg in de tweede helft van de jaren twintig. Ik zal niet langer specifiek de geschiedenis van plaatselijke instellingen beschrijven, maar proberen de nazorg in een landelijk perspectief te plaatsen. Ik ga in op het denken over zwakzinnigheid in het algemeen en binnen de nazorg in het bijzonder, op de verhouding tussen nazorg en aanverwante werkvelden en op de ontwikkelingen in de praktijk van de nazorg.

Het zesde hoofdstuk gaat over de ontwikkeling van de nazorg in de jaren dertig en heeft dezelfde opzet als het vierde hoofdstuk. Hier zal ik dieper ingaan op de specifieke maatschappelijke omstandigheden in deze periode, vooral op de economische crisis. De samenwerking tussen nazorgwerkers onderling, die in deze periode vaste vorm kreeg, komt nadrukkelijk aan bod.

Het zevende hoofdstuk handelt over de nazorg ten tijde van de Duitse bezetting. Vanzelfsprekend ligt de nadruk hier vooral op de maatschappelijke omstandigheden, die ingrijpend afweken van de voorgaande periodes. Ik ga in op de vraag, welke gevolgen deze omstandigheden hadden voor het handelen van nazorgwerkers. Aan het einde ga ik nog kort in op de situatie direct na de bevrijding.

In het achtste en laatste hoofdstuk probeer ik alle opgedane kennis samen te brengen door antwoord te geven op de deelvragen. Ik sluit af met de beantwoording van de hoofdvraag van dit onderzoek. 


\section{Hoofdstuk 2 \\ Grondslagen \\ 1900-1917}

“...zal nog iets deugdelijks verricht worden, dan is het zaak, het slechte gereedschap zoo goed mogelijk te gebruiken. "

M. van Wijhe, 1902 .

Dit hoofdstuk handelt over de directe voorgeschiedenis van de nazorg. Ik beschrijf in de eerste paragraaf de manier waarop aan het einde van de negentiende eeuw het begrippenapparaat om mensen met een verstandelijke handicap aan te duiden zich ontwikkelde tot de algemeen geaccepteerde terminologie die in de eerste helft van de twintigste eeuw gehanteerd werd. In de tweede paragraaf behandel ik de maatschappelijke omstandigheden in de eerste twee decennia van de twintigste eeuw. Daarna ga ik in op het ontstaan van het Buitengewoon Lager Onderwijs (BLO) en de redenen waarom men juist voor apart onderwijs aan zwakzinnigen koos. In de vierde paragraaf ga ik in op de manier waarop men in het vroege BLO dacht over wat er met de oud-leerlingen moest gebeuren en beschrijf ik een aantal vroege pogingen om de zorg voor deze groep vorm te geven.

In dit hoofdstuk komen alle onderzoeksvragen aan de orde. De nadruk ligt vooral op de vijfde onderzoeksvraag, over de verhouding tussen buitengewoon lager onderwijs en de nazorg. In deze periode werd de grondslag voor die verhouding gelegd.

\subsection{Begripsvorming}

Het begrippenapparaat rondom zwakzinnigheid heeft in de loop der eeuwen een ontwikkeling doorgemaakt, waarbij met enige regelmaat nieuwe termen werden geïntroduceerd en oude verdwenen of een andere betekenis kregen. Rond de overgang van de negentiende naar de twintigste eeuw deed zich op dit gebied een belangrijke verschuiving voor. Gedurende het grootste deel van de negentiende eeuw was de meest gangbare term om zwakzinnigheid aan te duiden idiotie geweest. Oorspronkelijk stamt deze term uit het Grieks. Idiotes werd gebruikt om mensen zonder bestuurlijk ambt of deskundigheid aan te duiden. Bij de Romeinen duidde idiota op ongeletterdheid en onontwikkeldheid. In de middeleeuwen en de vroegmoderne tijd werd de term gebruikt om mensen aan te duiden met een zekere zwakheid van geest. ${ }^{17}$ Deze betekenis droeg de term ook nog in de negentiende eeuw. Van Koetsveld, de onderwijspionier voor zwakzinnige kinderen gebruikte de naam idiotenschool voor zijn Geneeskundig Instituut voor Minderjarige Idioten in Den Haag, dat in 1855 de deuren opende. ${ }^{18} \mathrm{Klootsema},{ }^{19}$ de directeur van de eerste zelfstandige school voor BLO in Amsterdam en de belangrijkste Nederlandse theoreticus over zwakzinnigheid aan het begin van de twintigste eeuw, omschreef de term idiotie in 1904 als volgt:

"Onder idiotie toch verstaat men een reeks van aangeboren (congenitale) of in de vroegste jeugd ontstane (infantiele) stoornissen van het verstand, welke op traumatischen of op degeneratieven bodem rusten (trauma = wonde). Men heeft alle moeite gedaan, om tot een nauwkeurige begripsbepaling van idiotie te gera- 
moeite gedaan, om tot een nauwkeurige begripsbepaling van idiotie te geraken; maar tot op heden kan men vrijelijk al deze pogingen als mislukt beschouwen. (...) Men doet dan ook wijselijk, om van de idiotie niets anders te zeggen dan dat ze een groep congenitale of infantiele verstandsstoornissen omvat, die te zamen zwevende overgangen vormen van het volkomen abnormale naar het gezonde intellect. ${ }^{20}$

Toch was in deze periode de betekenis van de term idiotie al aan het verschuiven. Het werd steeds vaker gebruikt om de ernstigste graad van een verstandelijk gebrek aan te duiden, naast imbecilliteit voor een matig verstandelijk gebrek en debiliteit voor de lichtste vorm ervan. Ook Klootsema gebruikte deze driedeling, toen hij in 1904 sprak over 'idiotie (in engere zin), imbecilliteit en debiliteit' ${ }^{21}$ De betekenis van idiotie werd door deze ontwikkeling ingeperkt en verloor uiteindelijk haar oude betekenis geheel.

Intussen was er binnen het onderwijs voor kinderen met een handicap een nieuwe term in zwang geraakt. Toen de onderwijspionier Fokke Yntes Kingma (1813-1883) in 1858 zijn Algemeene Supplementaire School in Utrecht begon, richtte hij zich op wat hij achterlijke kinderen noemde. Daarmee bedoelde hij kinderen die in het gewone onderwijs achterliepen en daardoor een probleem vormden. ${ }^{22}$ Toen het Rotterdamse schoolhoofd Daniël Köhler in 1896 een experiment startte waarbij kinderen die problemen hadden met het volgen van de lesstof op zijn gewone lagere school in een aparte klas les kregen, duidde hij deze kinderen eveneens aan als achterlijk. De vorm van onderwijs die hij begon, raakte bekend onder de naam school voor achterlijke kinderen. In 1902 onderscheidde M. van Wijhe, in een brochure van de Maatschappij tot Nut van 't Algemeen, binnen de groep achterlijken de achterblijvers met een trage hersengroei en de dommen, van wie de hersenschors van mindere kwaliteit zou zijn. Hij bracht een differentiatie binnen het begrip achterlijkheid aan, tussen enerzijds de kinderen die achterliepen maar die achterstand weer zouden kunnen inhalen en anderzijds die kinderen die hun schoolachterstand niet in zouden kunnen halen vanwege een defect aan de hersenen. $^{23}$

Juist deze meervoudige betekenis leidde ertoe dat in 1903 de term uit het ambtelijke taalgebruik werd geschrapt. De naam school voor achterlijke kinderen werd vervangen door het meer neutraal geachte Buitengewoon Lager Onderwijs. Achterlijkheid was inmiddels in de volksmond een scheldwoord geworden en veel ouders vonden het voor hun kinderen stigmatiserend, als zij naar de achterlijkenschool moesten gaan. ${ }^{24}$

De meervoudige betekenis van achterlijkheid leidde er ook toe dat in 1905 onder verantwoordelijkheid van Abraham Kuyper, de minister van binnenlandse zaken en in die functie ook verantwoordelijk voor onderwijs, de term zwakzinnigheid geïntroduceerd werd om de doelgroep van het BLO aan te duiden.

"Achterlijk kan een kind zijn, wiens hersenen zoo gezond mogelijk ontwikkeld zijn. Zwakzinnig daarentegen duidt volkomen helder op iemand, wiens zinnen niet de normale sterkte hebben zonder dat nochtans de graad van het idioot-zijn moet worden aangenomen. ${ }^{25}$

Aanvankelijk diende zwakzinnigheid alleen om de lichtere vormen van een verstandelijk gebrek aan te duiden. Maar al in de loop van de jaren 1910-1920 zou de 
term de oude betekenis van idiotie overnemen en gebruikt worden als algemene term voor alle vormen van verstandelijke handicap. Dat proces was rond 1915 al vrijwel voltooid, toen J.H. Schuurmans Stekhoven, inspecteur van het krankzinnigenwezen, er in de Psychiatrische en Neurologische Bladen voor pleitte om in de wetgeving de term idiotie door zwakzinnigheid te vervangen, omdat de populatie van de idiotengestichten niet alleen uit idioten maar ook uit imbecillen bestond. ${ }^{26}$

Aan zwakzinnigheid kleefden veel negatieve connotaties. Dat had ermee te maken dat door een deel van de hulpverlenende gemeenschap de lichtere vormen van een verstandelijk gebrek verantwoordelijk werden gehouden voor de ernstige maatschappelijke problemen van die tijd. Daarbij ging het om zaken zoals pauperisme, prostitutie, vagebondisme en criminaliteit. Zwakzinnigheid werd als Nederlandse vertaling gebruikt voor de Engelse term feeble-mindedness, dat een zéer negatieve inhoud had:

"Life was a struggle in which the feeble-minded sank to the bottom. They filled our prisons, clogged our schools, burdened our Poor Law institutions, occupied our homes for the inebriates. And what was worse, they accumulated in our slums out of contact with any institution of the State and open to exploitation by others." ${ }^{27}$

De feeble-minded, die een klein verstandelijk gebrek zouden hebben dat niet of moeilijk was vast te stellen, werden beschouwd als een bron van gevaar voor de samenleving als geheel. Ze werden als antisociaal en crimineel beschouwd en zouden deze eigenschappen in verergerde vorm aan hun kinderen doorgeven. De feeble-minded zouden zich sneller voortplanten dan normale mensen en er daardoor voor zorgen, dat de kwaliteit van de bevolking als geheel achteruit ging. ${ }^{28}$

Onderliggende gedachte bij deze negatieve houding ten opzichte van zwakzinnigen in de gehele westerse wereld was, dat de intellectuele functie het belangrijkste onderscheidende kenmerk was van de mens ten opzichte van het dier zou zijn. Mensen met een verstandelijk gebrek werden gezien als minderwaardig aan mensen met een normale of goede intellectuele functie. Er werd verondersteld dat zwakzinnigen afzakten tot de allerlaagste sociale klassen, waar zich de hierboven beschreven maatschappelijke problematiek opeenhoopte. ${ }^{29}$ Dit beeld van zwakzinnigheid leek bevestigd te worden door het proefschrift Voogdij voor Zwakzinnigen van C.J. Bartels uit 1916. Hij constateerde dat de zwakzinnige populatie van opvoedingsgestichten, waar kinderen en jongvolwassenen gedwongen geplaatst waren, vaak afkomstig was uit sociale milieus waar ontstellend slechte omstandigheden heersten en zaken als prostitutie, verwaarlozing en incest vaak voorkwamen. $^{30}$

Het was de in 1910 opgerichte Centrale Vereeniging ter Behartiging van de Belangen van Zwakzinnigen die voor verdere begripsverwarring rondom de term zwakzinnigheid zorgde. ${ }^{31}$ Deze vereniging, met onder de oprichters het puikje van de Nederlandse psychiatrie en residentiële zwakzinnigenzorg, was opgericht uit zorg over het groeiende aantal sociale afwijkelingen in Nederland. Die groei werd onder andere afgeleid uit de toename van het aantal geïnterneerden in krankzinnigengestichten: vanaf de invoering van de krankzinnigenwet in 1884 tot aan de eeuwwisseling was hun aantal bijna verdubbeld tot meer dan 8300 en in de eerste jaren van de twintigste eeuw zette deze groei door. ${ }^{32}$ Schuurmans Stekhoven 
schreef er in 1913 een artikel over in het verenigingsblad, het Tijdschrift voor Zwakzinnigenzorg, waarin hij pleitte voor een instituut dat de groei van het percentage 'psychopaten, zwakzinnigen, idioten, krankzinnigen, drankzuchtigen, misdadige elementen' nauwlettend in de gaten moest houden. ${ }^{33}$

De vereniging als geheel en verschillende auteurs die in het Tijdschrift voor Zwakzinnigenzorg publiceerden, sprongen slordig om met de wijze waarop de doelgroep omschreven werd. Zwakzinnigheid werd vaak gelijkgesteld aan psychopathie, een term die afkomstig was uit de psychiatrie en veel negatievere connotaties had dan zwakzinnigheid. ${ }^{34}$

De term psychopathie was afkomstig uit het Duitse taalgebied. Daar heeft Emil Kraepelin, de meest vooraanstaande psychiater van zijn tijd, zich nadrukkelijk met dit onderwerp beziggehouden. Hij beschouwde wat hij noemde Psychopathische Persönlichkeiten als mensen die Gesellschaftsfeindlich en Antisozial waren. Hij onderscheidde een aantal groepen psychopathen, zoals geboren criminelen, onstabielen en compulsieve leugenaars. Mensen met een intellectueel defect beschouwde hij nadrukkelijk niet als psychopathisch. ${ }^{35}$ Psychopathie werd beschouwd als een defect aan het karakter, dat vooral tot uitdrukking zou komen in een a- of antisociale instelling. ${ }^{36} \mathrm{Dr}$. Slot, directeur van de Rekkensche Inrichtingen in de Achterhoek, die zich speciaal op de zorg voor psychopathen richtten, omschreef hen als volgt:

“... menschen, die niet kunnen overzien de gevolgen hunner handelingen, telkens van het eene uiterste in het andere vallen, zich niet aan het maatschappelijk leven kunnen aanpassen en, wanneer zij anti-sociale neigingen hebben, allicht tot misdaad vervallen. ${ }^{37}$

$\mathrm{Na}$ het midden van de jaren tien werden zwakzinnigheid en psychopathie in de vakliteratuur beter van elkaar onderscheiden. A. van Voorthuijsen, de latere inspecteur bij het BLO, klaagde in 1917 over het onjuiste gebruik van de term psychopathie:

"Hierbij dient te worden opgemerkt, dat in niet-medische kringen de naam van psychopathen dikwijls wordt gebruikt voor alle mogelijke stoornissen, die bij kinderen en ook bij volwassenen voorkomen. ${ }^{38}$

Ook Klootsema maakte in 1916 een duidelijk onderscheid tussen psychopathie en zwakzinnigheid:

"Psychopathen behooren niet thuis op een school voor zwakzinnigen. Het zijn geen idioten, imbecillen of debielen. Psychopathen zijn mensen, wier secundaire geestesfunctie abnormaal is, het zijn onevenwichtige wezens, bij wie men aantreft: ideeënjacht, hysterie, vluchtigheid, paranoia e.a." ${ }^{39}$

Psychopathie zou zich in Nederland ontwikkelen tot een verzamelterm waarmee allerlei vormen van sociaal onaangepast gedrag werden aangeduid en waarvan verondersteld werd dat zij een gemeenschappelijke onderliggende oorzaak hadden. Wat die oorzaak was heeft men nooit kunnen achterhalen. Daardoor lukte het niet psychopathie afdoende te definiëren. Pogingen daartoe waren meestal niet meer dan opsommingen van verschillende soorten sociale afwijkelingen zoals bijvoorbeeld die van de psychiater Bierens de Haan uit 1925: 
2. De niet-krimineelen:
a. de prostituées
b. de verslaafden
c. de vagabondeerders
d. de verkwisters
e. de hun kinderen verwaarloozenden
f. de ontoelaatbaren
g. de in hun gezinsleven moeilijken
h. de homo-sexueelen."

Het gebruik van de term psychopathie kan worden geïnterpreteerd als een poging om sociale afwijkendheid te medicaliseren en het verschijnsel te zien als een ziekte van het betrokken individu en niet als een (deels) maatschappelijk bepaald probleem.

In Nederland bestond grote angst voor psychopathen. Het leidde ertoe dat in de jaren tien en twintig van de twintigste eeuw twee psychopathenwetten werden aangenomen, die overigens alleen informeel zo werden genoemd. In $1915 \mathrm{kwam}$ de Wet op de Voorwaardelijke Veroordeling tot stand $\mathrm{d}^{40}$, die de rechter de mogelijkheid bood een straf geheel of gedeeltelijk op te schorten om deze bij herhaling van de gepleegde feiten alsnog ten uitvoer te leggen. De opschorting kon ook worden opgelegd onder voorwaarde van geregeld contact met de reclassering. Hierdoor hoopte men het gedrag van veroordeelde psychopathen beter onder controle te kunnen houden. Langer duurde het voordat de tweede en belangrijkste psychopathenwet, de Wet op de Terbeschikkingstelling van de Regeering ${ }^{41}$ van kracht werd. Het wetsontwerp, dat het mogelijk moest maken om veroordeelde psychopathen onder dwang psychiatrisch te laten verplegen, werd al begin 1911 bij de Tweede Kamer ingediend. Na lange discussie werd deze wet in 1925 in het parlement goedgekeurd, om pas eind 1928 van kracht te worden. ${ }^{42}$

\subsection{Maatschappelijke ontwikkelingen}

In de tweede helft van de negentiende eeuw voltrok zich in Nederland een groot aantal maatschappelijke veranderingen. Belangrijkste daarvan waren de industrialisering gecombineerd met de mechanisatie van de landbouw. Hierdoor nam de werkgelegenheid op het platteland aanzienlijk af, terwijl deze in de stedelijke industriële centra enorm toenam. Dit proces kwam vanaf 1875 goed op gang en leidde ertoe dat het zwaartepunt van de bevolking in Nederland verschoof van het platteland naar de steden. Van 1870 tot 1900 groeide de bevolking van de vier grote steden met 110 procent. De middelgrote steden groeiden in deze periode met $62 \%$, op het platteland nam de bevolking in dezelfde periode met slechts $17 \%$ toe. ${ }^{43} \mathrm{De}$ helft van deze toename was toe te schrijven aan natuurlijke groei, de andere helft bestond uit binnenlandse migratie. Tegelijkertijd groeide de Nederlandse bevolking als geheel van 3,6 miljoen in 1869 naar 5,1 miljoen in $1900 .^{44}$

De bevolkingsexplosie in de steden, die moeilijk onder controle viel te houden, leidde tot veel sociale problematiek. Woon- en leefomstandigheden voor de lagere sociale klassen waren vaak ontstellend slecht, de lonen in de industrie waren laag en de werktijden lang. Kinderarbeid was een gewoon verschijnsel, omdat het voor veel gezinnen niet mogelijk was om zonder het inkomen van de kinde- 
ren te overleven. Het leidde onder andere tot het ontstaan van de eerste vakbonden, waarin men probeerde door onderlinge samenwerking de levensomstandigheden van de arbeiders te verbeteren. Allereerst waren het vooral de socialisten die zich hiermee bezighielden, later volgden ook katholieken en protestants-christelijke vakverenigingen.

Door de invloed van de vakverenigingen verbeterden de omstandigheden van de arbeiders daadwerkelijk. Het werd aan het einde van de negentiende eeuw mogelijk dat slechts één gezinslid, meestal de man, loonarbeid verrichtte om daarmee het gezin te onderhouden. Er ontwikkelde zich een arbeidsmoraal, die breed werd gedragen in de maatschappij (door liberalen, confessionelen en sociaaldemocraten) en die inhield dat arbeid naast een economische ook een intrinsieke waarde had: arbeid was in zichzelf goed en droeg bij aan de zelfverwezenlijking van de mens. In zekere zin was men pas écht mens als men arbeid kon verrichten. ${ }^{45}$

Tegelijkertijd werden de maatschappelijke regels strenger. Burgerlijke normen en waarden, vooral met betrekking tot een ordelijk gezinsleven, werden steeds dwingender aan de lagere klassen opgelegd. Deze ontwikkeling, onderdeel van het civilisatieproces, wordt ook wel burgerlijk beschavingsoffensief genoemd maar werd breder gedragen in de Nederlandse samenleving. Naast de burgerij nam ook de sociaal-democratische beweging er deel aan. ${ }^{46}$ Dat leidde er enerzijds toe dat de grenzen tussen normaal en niet-normaal duidelijker werden getrokken en anderzijds dat ingrijpen in niet-normale situaties op steeds meer instemming kon rekenen. Het werd steeds vanzelfsprekender geacht dat hulpverleners ingrepen in de privé-levens van mensen als die aan de verkeerde kant van de lijn stonden. Steeds meer werd het als een probleem beschouwd dat een dergelijk ingrijpen niet door de overheid werd gesanctioneerd. Het leidde ertoe dat er in het laatste kwart van de negentiende en het eerste kwart van de twintigste eeuw een aantal wetten tot stand kwamen, die steeds dieper ingrepen in het leven van haar burgers mogelijk maakten. Dat begon in 1874 betrekkelijk eenvoudig met het Kinderwetje van Van Houten, waarmee de kinderarbeid aan banden werd gelegd. Ook de Leerplichtwet van 1901 betekende overheidsingrijpen in gezinsverhoudingen, maar het ingrijpendst waren toch wel de Kinderwetten van 1905, waardoor het mogelijk werd om ouders, als zij hun kinderen verwaarloosden, geheel uit de ouderlijke macht te ontzetten of hen daarvan te ontheffen. ${ }^{47}$ De Zedelijkheidswetgeving van 1911 , waarin de regels met betrekking tot pornografie en homoseksualiteit werden verscherpt en abortus en het houden van een bordeel werden verboden, zijn een andere verschijningsvorm van de strenger wordende openbare moraal in het eerste kwart van de twintigste eeuw. ${ }^{48}$

Deze ontwikkeling nam in Nederland een speciale vorm aan. Dat had te maken met de bijzondere samenstelling van de bevolking. Het land werd niet beheerst door één grote sociaal-culturele groepering, maar was samengesteld uit verschillende naast elkaar bestaande levensbeschouwelijke stromingen waarvan er niet één de hegemonie had. Zij tolereerden elkaars bestaan maar stonden in relatieve geïsoleerdheid tot elkaar. Deze zuilen waren grofweg te verdelen in katholieken, protestanten, liberalen en vanaf het einde van de negentiende eeuw ook de sociaaldemocraten. Vooral de confessionele elites, de katholieken en de protestantschristelijken, probeerden deze verzuiling in stand te houden en verder te ontwikke- 
len om hun eigen machtsbasis in stand te houden. Dat deden ze onder meer door ernaar te streven zoveel mogelijk onderdelen van het (dagelijkse) leven binnen de eigen zuil te laten plaatsvinden, zodat contacten buiten de eigen kring hoogst zelden noodzakelijk waren.

Door de invoering van het algemeen kiesrecht na de Eerste Wereldoorlog hadden de confessionele elites veel invloed gekregen op landelijk niveau, ten koste van de liberalen. Deze macht werd door hen nadrukkelijk gebruikt om de eigen waarden en normen aan de gehele Nederlandse samenleving op te leggen. ${ }^{49}$ Dat gebeurde op een voor het verzuilde Nederland typische manier. Het was niet de staat zelf die rechtstreeks ingreep in de privé-levens van haar burgers. Haar rol bestond er enkel uit dit ingrijpen te legitimeren. Het werd uitgevoerd door verschillende op levensbeschouwelijke basis georganiseerde instellingen.

Vanuit liberale en socialistische kringen bestond er verzet tegen deze ontwikkeling. Hier vond men het onnodig dat er op gebieden die niets met levensbeschouwing of politieke overtuiging te maken hadden, verschillende verzuilde organisaties actief waren. Zij waren voorstanders van 'algemene' instellingen, maar hadden niet veel succes met dit streven. Gevolg ervan was, dat veel van deze algemene instellingen alleen uit liberalen en socialisten bestonden, die daardoor tot een ongemakkelijk bondgenootschap werden gedwongen.

Binnen de hulpverlening was in deze periode een proces van professionalisering gaande. In de negentiende eeuw overheerste het filantropische model, waarbij voorwaardelijke hulpverlening werd uitgevoerd door vrijwilligers uit de betere standen. Onder de nieuwe omstandigheden, waarbij ingrijpen onder verantwoordelijkheid van de overheid plaatsvond, voldeed vrijwillige hulpverlening niet langer. Er was té veel specialistische kennis voor nodig en het werk kostte té veel tijd om nog langer door vrijwilligers uitgevoerd te kunnen worden. Het verschijnsel maatschappelijk werk deed zijn intrede. Tegelijkertijd ontstonden de eerste professionele opleidingen voor deze nieuwe beroepsgroep, waarvan de eerste onder de naam opleidingsinrichting voor sociale arbeid in Amsterdam in 1899 de deuren opende..$^{50}$

\subsection{Ontstaan van het Buitengewoon Lager Onderwijs}

In 1901 werd de zesjarige leerplicht in Nederland ingevoerd. Alle kinderen tussen 6 en 12 jaar werden verplicht om onderwijs te volgen. De directe gevolgen van deze wet leken beperkt. Het betekende niet, dat in 1901 grote groepen nieuwe leerlingen de scholen binnenstroomden. Aan het einde van de negentiende eeuw was het volgen van onderwijs al vrijwel algemeen geworden. In 1895 bezocht $90 \%$ van de kinderen tot 13 jaar de school. In 1903, twee jaar na de invoering van de leerplichtwet, was dat percentage tot $95 \%$ gestegen. ${ }^{51}$ De leerplichtwet valt daarom het beste te interpreteren als een wettelijke sanctionering achteraf van een inmiddels vrijwel algemeen geworden gebruik. ${ }^{52}$

De belangrijkste verandering die de leerplichtwet met zich meebracht was dat ouders voortaan door de overheid gedwongen konden worden om hun kinderen naar school te sturen.

Voor de scholen betekende de wet dat zij niet langer de mogelijkheid hadden om lastige kinderen, die het onderwijs vertraagden of verstoorden, van school te ver- 
wijderen. M. van Wijhe, die in 1902 als één van de eersten over achterlijkheid publiceerde, gaf aan wat daarvan het gevolg was:

"En nu de nieuwe wet tot schoolgaan dwingt, kan geen moeder een stumperdje thuis houden, om het daaraan te onttrekken, indien het overigens gezond is." 53

Een belangrijke factor hierbij was, dat in de loop van de negentiende eeuw het onderwijsprogramma dat op de lagere school moest worden afgewerkt, steeds vaster was komen te liggen. Ieder jaar moest een vast omschreven hoeveelheid leerstof worden behandeld in het leerstofjaarklassensysteem ${ }^{54}$ Kinderen die niet of onvoldoende snel in dit systeem konden meekomen, gingen hierdoor opvallen. De oorzaak hiervan werd niet zozeer in het systeem gezocht, maar bij die kinderen zelf gelegd. $\mathrm{Zij}$ werden geclassificeerd als achterlijk, wat aanvankelijk niet meer of minder betekende dan dat ze achter liepen. Ze werden op drie verschillende punten als een probleem beschouwd, zoals een betrokkene bij de oprichting van het Haagse BLO in 1901 omschreef:
" $1^{\circ}$.
Er zijn voor hen zelve (achterlijke kinderen, LB) op de gewone scholen
zeer weinig gunstige resultaten te verwachten;
$2^{\circ}$. Hunne aanwezigheid werkt in de klassen belemmerend op den vooruit-
gang der andere leerlingen;
$3^{\circ}$. Hunne aanwezigheid is nadeelig voor het zenuwgestel van de onderwij-
zers, die met zoo geheel verschillende kinderen moeten werken. ${ }^{55}$

Nog voordat de leerplichtwet werd ingevoerd, in 1896, was in Rotterdam al een proef van start gegaan om het achterlijkenprobleem op te lossen. Daniël Köhler, hoofd van een school voor gewoon lager onderwijs, was in dat jaar begonnen met een aparte klas voor achterlijke kinderen die verbonden was aan zijn eigen school. Het idee hiervoor had hij opgedaan in Duitsland, waar al vanaf 1867 een stelsel van Hilfsschulen en Hilfsklassen in ontwikkeling was. Kinderen die niet in het reguliere schoolsysteem mee konden komen, kregen aangepast onderwijs in aparte klassen of scholen. ${ }^{56}$ In 1895 gebeurde dat al in 44 verschillende plaatsen. ${ }^{57}$ In dat jaar bezocht Köhler de Hilfsklassen in Braunschweig, ${ }^{58}$ die vanaf 1881 bestonden ${ }^{59}$ Hierover rapporteerde hij positief aan de Rotterdamse gemeenteraad, die er aanleiding in zag om een proef te nemen met dit Brunswijkse model. Köhler begon een bijklasse van 16 leerlingen, in 1898 gevolgd door een tweede. ${ }^{60}$ De resultaten werden als zó gunstig beschouwd, dat de bijklassen een permanent karakter kregen. Tussen 1905 en 1907 groeide hun aantal tot in totaal 8. In 1907 werden ze verzelfstandigd tot een aparte school, waarvan Köhler het hoofd werd. ${ }^{61}$

De proef met de Rotterdamse klassen werd in het land met belangstelling gevolgd. In 1899 leidde dat in Amsterdam tot de oprichting van de eerste zelfstandige Nederlandse dagschool voor achterlijke kinderen, geëxploiteerd door de $\mathrm{Ver}$ eeniging voor Spraakgebrekkige en Achterlijke Kinderen, die al in de jaren zeventig van de negentiende eeuw was opgericht door de al eerder aangehaalde F.Y. Kingma. Daarna kwamen er in meer gemeenten scholen voor achterlijke kinderen. In 1910 waren er in totaal 10, met bij elkaar 1032 leerlingen. ${ }^{62}$

Op de meeste plaatsen koos men voor zelfstandige scholen voor achterlijke kinderen en niet voor aparte klassen. Hiervoor zijn verschillende redenen aan te geven. Allereerst bestond de angst, dat de leerlingen van de bijklassen door hun 
normale schoolgenootjes gepest zouden worden vanwege hun achterlijkheid. Op een zelfstandige school zou daar geen sprake van zijn. Daarnaast vreesde men, dat in de bijklassen kinderen van een té verschillend niveau bij elkaar geplaatst zouden worden, waardoor het voor de leerkracht moeilijk zou worden om ieder op het eigen niveau les te geven. ${ }^{63}$ Verder speelde een rapport uit 1903 van de drie inspecteurs van het lager onderwijs een rol. Zij hadden in Duitsland verschillende Hilfsklassen en Hilfsschulen bezocht en kwamen in hun rapport daarover tot de conclusie dat het belangrijkste argument dat vóór bijklassen sprak niet opging: van de kinderen, die in een Hilfsklasse terechtkwamen, stroomden er maar erg weinig terug naar het reguliere onderwijs. ${ }^{64}$ Ten slotte speelde de politiek nog een rol. Minister Kuyper vreesde in 1905 dat de bijklassen door de scholen waaraan zij verbonden waren gebruikt zouden worden als vergaarbak voor alle lastige en langzame kinderen waar men in het reguliere onderwijs vanaf wilde en niet, zoals eigenlijk de bedoeling was, de toegang zou beperken tot kinderen met een gebrek. Hij ging er van uit, dat zelfstandige scholen hun toelatingscriteria strenger zouden kunnen hanteren. ${ }^{65}$

Het idee dat achterlijke kinderen het beste uit het reguliere onderwijs verwijderd konden worden om op een aparte school les te krijgen had vooral te maken met de manier waarop er binnen het onderwijs tegen zwakzinnigheid werd aangekeken. Zwakzinnigheid werd, zoals ik al in paragraaf 2.1 heb laten zien, in verband gebracht met onmaatschappelijkheid en asociaal gedrag, waarbij aanleg een belangrijke rol zou spelen. Daarbij had men vooral de lichtzwakzinnigen, de debielen op het oog, de belangrijkste doelgroep van het buitengewoon onderwijs. Daarnaast bestond het idee dat die aanleg niet tot uiting hoefde te komen als de omgeving waarin lichtzwakzinnigen verkeerden maar goed was. D. Herderschêe, schoolarts bij het Amsterdamse BLO, ${ }^{66}$ gaf dat in 1917 het duidelijkste weer:

\begin{abstract}
"Zeker heeft Goddard gelijk, wanneer hij zegt dat de zwakzinnigen potentieel dronkaards, prostituées en vagebonden zijn, maar daarom zijn ze dit nog niet actueel (...) Om de mogelijkheid tot werkelijkheid te maken, is nog iets anders noodig dan een bepaalde aanleg, en wel de invloed van bepaalde uiterlijke omstandigheden, met één woord van het milieu." ${ }^{67}$
\end{abstract}

Het geloof in die slechte aanleg had te maken met de eugenetische visie op zwakzinnigheid, volgens welke deze zou voorbestemmen tot a- en antisociaal gedrag. Die relatie kon niet bewezen worden, maar het tegendeel evenmin. Gevolg was dat men in brede kring, ook in sociaalhygiënische, uitging van de waarheid van deze visie. Door lichtzwakzinnige kinderen uit het hun vijandige milieu van de normale school te halen en hen in de beschermende omgeving van de achterlijkenschool onder te brengen, hoopte men te kunnen voorkomen dat de eventuele slechte aanleg die in hen schuilde tot ontwikkeling zou komen.

"Zij (de zwakzinnige kinderen, LB) worden in een omgeving geplaatst waar zij zich kunnen aanpassen, zoodat niet langer een niet te overbruggen kloof voor hen bestaat, die hen van hun medemenschen onderscheidt. ${ }^{n 68}$

De onderwijzers in deze nieuwe vorm van onderwijs hoopten hen op een aangepaste manier zoveel kennis en vaardigheden bij te brengen, dat zij zich na het verlaten 
van de school zelfstandig in de maatschappij zouden kunnen handhaven. Want het geloof in de kracht van de pedagogiek was onder de onderwijzers in het BLO minstens zo groot als het geloof in de slechte aanleg van zwakzinnigen.

Bij de keuze voor het aparte onderwijs voor zwakzinnigen nam men bewust de stigmatisering die daarmee samenhing op de koop toe. De redenering daarbij was dat stigmatisering in het reguliere onderwijs, voordat een kind tot het BLO was toegelaten, toch al had plaatsgevonden. Het speciale onderwijs voor zwakzinnigen probeerde de gevolgen daarvan tot aanvaardbare proporties terug te brengen, zoals G.J. van der Ploeg, hoofd van de christelijke BLO-school in Rotterdam aan het einde van de jaren twintig beschreef:

\begin{abstract}
"Uit onze eigen schooljaren herinneren we ons toch ook nog wel de 'domme' leerlingen en onze eigen kinderen hebben het in verhalen, die ze thuis doen over de school, o.a. telkens weer over dit of dat kind, dat zo erg dom is. Ze zijn reeds getekend en de plaatsing op een school voor B.O. kan er alleen maar toe meewerken, dat er nog met de beschikbare middelen van gemaakt wordt wat mogelijk is. Het teken wordt bij ons niet gegeven, maar tot de kleinste proporties teruggebracht." 69
\end{abstract}

Het reguliere onderwijs vond het BLO eveneens belangrijk, maar dan vooral als middel om van haar eigen lastige leerlingen af te komen. ${ }^{70} \mathrm{Er}$ werden veel kinderen voor plaatsing op het BLO aangemeld die lastig waren, maar geen verstandelijk gebrek hadden. Daarom beschikten alle scholen voor BLO over een toelatingscommissie, waarin in elk geval een arts was opgenomen. Een eenduidig en algemeen geaccepteerd middel om vast te stellen of een kind een verstandelijk gebrek had ontbrak vooralsnog. De selectie gebeurde op grond van volstrekt subjectieve criteria, gebaseerd op de ervaring die men inmiddels had opgedaan. ${ }^{71}$ Soms werden kinderen letterlijk naar de ogen gekeken:

"Uiterlijk komen allen vrij wel overeen: men herkent ze spoedig aan de uitdrukking der oogen, de manier van spreken, de drukke, overtollige bewegingen of iets dergelijks." 72

In 1913 probeerde de schoolarts bij het Amsterdamse BLO, D. Herderschêe, in deze situatie verandering te brengen door de Echelle Métrique de l'Intelligence, die door Binet en Simon in 1905 in Frankrijk was ontwikkeld in het Nederlands te vertalen. Deze test zou de mogelijkheid bieden om de verstandelijke vermogens van kinderen te meten. ${ }^{73}$ Herderschêe gebruikte de test aanvankelijk alleen bij de toelating tot de BLO-scholen in Amsterdam en paste ze in de loop van enkele jaren aan de Nederlandse omstandigheden aan. ${ }^{74}$ In de rest van het land moesten de scholen voor BLO wachten tot 1919, toen de Binet-Simon-Herderschêe-test werd gepubliceerd. De test zou in aangepaste vorm tot in de jaren zestig van de twintigste eeuw in gebruik blijven. ${ }^{75}$

De nieuwe maatstaf beviel goed. Betrokkenen bij het BLO waren ervan overtuigd dat door het gebruik ervan kon worden voorkomen dat niet-zwakzinnige kinderen op hun scholen werden toegelaten. De nieuwe selectiemethode leidde bij het reguliere onderwijs tot onvrede, omdat het nu niet langer mogelijk was om alle lastige leerlingen aan het BLO over te dragen, zoals in 1921 de Amsterdamse afdeling van de (sociaal-democratische) Bond van Nederlandsche Onderwijzers moest 
constateren:

\begin{abstract}
"De praktijk van de z.g. 'achterlike school' heeft [...] niet geheel voldaan, in zoverre, dat de bestaande achterlike school slechts die leerlingen van de gewone school overneemt, welke zij in wetenschappelike zin als haar speciale discipelen herkent. Er blijven nu echter op de gewone school nog kinderen, die voor de bestaande achterlike school te dom of te knap zijn, doch in ieder geval op de gewone school ook niet horen."76
\end{abstract}

De relatie tussen buitengewoon en regulier lager onderwijs was, afgezien van de spanningen over de toelating tot het BLO, niet bepaald intensief. Het BLO zag zichzelf niet zozeer als een onderdeel van het onderwijs maar beschouwde zich veel meer als deel van de zorg voor zwakzinnigen. De opdracht bij het ontstaan van het $\mathrm{BLO}$ was om een nieuwe vorm van onderwijs te ontwikkelen aangepast aan de mogelijkheden van haar populatie. Daardoor stond de inhoudelijke ontwikkeling van het BLO vrijwel geheel los van de ontwikkelingen in het gewoon lager onderwijs. In het BLO ontwikkelde men een eigen didactiek met eigen lesmateriaal, waarbij de nadruk verschoof van klassikaal naar individueel onderwijs. Contacten hierover vonden vrijwel uitsluitend binnen eigen kring plaats. ${ }^{77}$

Belangrijk voor die onderlinge contacten waren de organisaties van onderwijzers en andere betrokkenen die in het BLO werkzaam waren. In 1903 ontstond de eerste hiervan, de Vereeniging van Onderwijzers en Artsen, werkzaam aan inrichtingen voor onderwijs aan achterlijke en zenuwzwakke kinderen (in de wandeling afgekort tot $O \& A$ ), mede op initiatief van Daniël Köhler. ${ }^{78}$ De vereniging was enkele jaren de enige organisatie van betrokkenen bij het BLO in Nederland en verenigde alle gezindten in zich. Dat duurde tot 1912, toen de Vereeniging voor Christelijk Onderwijs aan achterlijke en zenuwzwakke kinderen werd opgericht, twaalf jaar later, in 1924, gevolgd door de Bond ter bevordering van het Rooms Katholiek Buitengewoon Lager Onderwijs aan zwakzinnigen. ${ }^{79}$

O\&A bleef lange tijd, ook nadat de confessionele bonden opgericht waren, het belangrijkste discussieforum over richting en inhoud die het BLO zou moeten krijgen. Centraal daarin stond het tijdschrift van de vereniging, dat aanvankelijk Tijdschrift van de Vereeniging van onderwijzers en artsen, werkzaam aan inrichtingen voor onderwijs aan achterlijke en zenuwzwakke kinderen heette, tussen 1917 en 1920 PAIS en na 1920 haar uiteindelijke naam, Tijdschrift voor Buitengewoon Onderwijs kreeg. Pas in het midden van de jaren twintig kreeg het tijdschrift van O\&A concurrentie, toen in 1925 de katholieke bond met het Tijdschrift voor R.K. Buitengewoon Onderwijs begon. Pas veel later, in 1938, kreeg ook de christelijke bond een tijdschrift, het Correspondentieblad voor Christelijk Buitengewoon Onderwijs, waarvan overigens geen vooroorlogse exemplaren bewaard zijn gebleven. $^{80}$

\title{
2.4 Eerste pogingen tot hulpverlening aan oud-leerlingen van het BLO
}

\subsubsection{Patronaat}

De negatieve ideeën die er over zwakzinnigheid bestonden leidden er binnen het BLO toe dat men zich zorgen ging maken over de vraag, wat er met haar pupillen zou gebeuren als deze eenmaal de school hadden verlaten. Dan viel het milieu weg 
dat hen had beschermd tegen de boze buitenwereld en was de kans groot dat, zonder mogelijkheden tot pedagogische correctie, hun aanleg tot verkeerd gedrag alsnog de overhand zou krijgen.

Individuele onderwijzers vonden dat er voor hen een taak op dit gebied was weggelegd. Ze zochten voor hun oud-leerlingen werk en hielden ze de eerste periode zo goed en zo kwaad als het ging in de gaten. De toestand van de oudleerlingen werd een vast onderdeel van de verslagen die de scholen voor BLO jaarlijks aan de gemeentelijke en landelijke overheden uitbrachten. Zo meldde het hoofd van de Arnhemse school voor BLO in 1911 over de twaalf leerlingen die dat jaar zijn school hadden verlaten, dat de jongens op één na vrij goed waren terechtgekomen en dat de meisjes in de huishouding werkten. ${ }^{81}$ Veel diepgaander dan dat zou deze verslaglegging niet gaan.

Er werd in brede kring nagedacht over de vraag, hoe de hulp aan oudleerlingen van het BLO vorm gegeven zou kunnen worden. Daarbij werd aanvankelijk onderbrenging in internaten en gestichten niet uitgesloten, zoals A.J. Calliber, hoofd van de christelijke school voor BLO in Rotterdam, in 1919 formuleerde:

"Zal het zwakz. onderwijs zich voldoende ontwikkelen, dan zal de regeering de oprichting van internaten moeten ter hand nemen, of wel deze flink subsidieeren. Of dit nu groote of kleine inrichtingen moeten zijn, daarover valt nog wel te praten." ${ }^{82}$

Veel betrokkenen bij het BLO vonden de grote stad een volstrekt verkeerde omgeving voor zwakzinnigen, omdat juist hier de verleiding tot het kwade het grootst zou zijn. Er werd gedacht over vormen van gezinsverpleging op het platteland, die vaak aansloten bij de al bestaande systemen van stadsbestedelingen. Dat was een vorm van zorg, waarbij armen die niet zelfstandig konden wonen en niet bij familie konden worden ondergebracht, op kosten van de gemeente in gezinnen buiten de stad werden geplaatst. Kenmerkend voor degenen die zich hiermee bezighielden was, dat het dorpsleven vaak érg geïdealiseerd voorgesteld terwijl het stadse leven alleen in inktzwarte tonen kon worden geschilderd. $^{83}$

De meeste betrokkenen van het BLO waren realistischer van aard en gingen er van uit dat de zorg voor oud-leerlingen in hun eigen sociale omgeving gegeven moest worden. Dat kostte het minste geld, terwijl de stap voor oudleerlingen en hun directe omgeving om hulp in te roepen het kleinste zou zijn. De praktijk wees bovendien uit, dat veel oud-leerlingen bij problemen al een beroep deden op hun oud-onderwijzers. ${ }^{84}$

Ook in Den Haag, waar in 1902 het BLO-onderwijs van start was gegaan, ${ }^{85}$ lag de verantwoordelijkheid voor de zorg voor de oud-leerlingen bij de onderwijzers. Hier voorzag men problemen als het aantal oud-leerlingen met de jaren zou toenemen en de belasting van de onderwijzers te groot zou worden. In 1904 werd de vereniging Zorg voor 't Achterlijke Kind opgericht, ${ }^{86}$ die zich bezighield met de praktische ondersteuning van de Haagse BLO-scholen. Dat deed ze onder andere door het uitzenden van leerlingen naar gezondheidskolonies op het platteland, het organiseren van schoolfeesten en het materieel ondersteunen van leerlingen uit arme gezinnen. In de doelstelling van deze organisa- 
tie was de zorg voor de oud-leerlingen nadrukkelijk opgenomen. ${ }^{87}$ In 1905 werd, om deze zorg concreet in te vullen, een aparte afdeling van de vereniging opgericht, die oud-leerlingen moest begeleiden bij het zoeken naar werk:

"Als onderafdeeling van de Vereeniging werd de Patroonsvereeniging opgericht. Er werd getracht, werkgevers als leden der Vereeniging te doen toetreden. Had men die maar eenmaal in voldoende hoeveelheid, dan was er meteen werkgelegenheid voor de ontslagen leerlingen." ${ }^{88}$

Het patronaat was in de negentiende eeuw een erg populaire vorm van hulpverlening geweest. Uitgangspunt daarbij was de vrijwillige hulp van goedwillende burgers, die hun minder fortuinlijke medeburgers met wijze raad en materiële hulp terzijde stonden. Het maakte onderdeel uit van de voorwaardelijke hulp, die in progressief-liberale kringen vanaf het einde van de achttiende eeuw in zwang was geraakt. In de tweede helft van de negentiende eeuw hadden in Nederland enkele patronaten de zorg op zich genomen voor ontslagen patiënten uit krankzinnigengestichten. Met geld en goede raad werden zij geholpen hun leven in de maatschappij weer vorm te geven. ${ }^{89}$ Wellicht dat deze patronaten als voorbeeld voor het Haagse BLO hebben gediend.

In het Den Haag van het begin van de twintigste eeuw bleek het erg moeilijk te zijn om voor de ondersteuning van oud-leerlingen van het BLO voldoende vrijwilligers te vinden. Het waren vooral de onderwijzeressen en onderwijzers, die men juist had willen ontlasten, die toetraden tot de patroonsvereniging. Hierdoor veranderde de feitelijke situatie amper. De weinige niet-onderwijsgevenden die wél bereid waren gevonden, bleken bovendien niet over voldoende kennis en gezag te beschikken om het werk goed te kunnen doen.

\begin{abstract}
"De patroons(essen) niet-onderwijzers zagen ten slotte het nuttelooze van hun pogingen in. De toestand werd langzamerhand weer zoo, dat de onderwijzers (essen) alleen er op aangewezen waren, om de ontslagen leerlingen te raden en te helpen en eenig toezicht op hen uit te oefenen. De patroonsvereeniging als onderdeel van 'Zorg voor het achterlijke kind' had geen reden van bestaan meer en ze werd opgeheven. ${ }^{.90}$
\end{abstract}

Deze opheffing vond in 1919 plaats. Vervolgens trad de wet van de remmende voorsprong in werking. Doordat het eerste experiment met de zorg aan oudleerlingen van het BLO mislukt was, kwam het Haagse BLO op dit gebied op achterstand te staan. Pas aan het einde van de jaren twintig groeide de aandacht voor de oud-leerlingen van het BLO weer. De gemeente liet een rapport over hun problematiek schrijven, maar pas aan het einde van de jaren dertig zou de zorg voor deze groep concreet ingevuld worden. ${ }^{91}$

Den Haag was niet de enige gemeente waarin werd geëxperimenteerd met de vrijwillige zorg voor oud-leerlingen van het BLO. In Rotterdam werd er in 1911 mee begonnen, toen de Commissie ter Behartiging der Belangen van Leerlingen en Oud-leerlingen der Buitengewone Scholen voor Lager Onderwijs werd opgericht. Eén van de doelstellingen van deze organisatie was het ondersteunen van oudleerlingen bij het zoeken naar werk. ${ }^{92}$ Financiële moeilijkheden leidden ertoe, dat in de praktijk amper hulp kon worden verleend. ${ }^{93}$ 


\title{
2.4.2 Voortgezette opleiding
}

In Rotterdam zocht men de oplossing voor het probleem van de oud-leerlingen in de verlenging van het schoolse verband. Op initiatief van Daniël Köhler waren hier in 1909 de ambachtscursussen voor zwakzinnigen tot stand gekomen, onder leiding van de onderwijzer C. de Haan:

\begin{abstract}
"Nadat we in ' 96 met het onderwijs aan zwakzinnigen waren begonnen, zagen we na 6 à 7 jaar wel in, dat dit alleen niet voldoende was om onze leerlingen in de maatschappij een bescheiden plaatsje te verschaffen. Nadat we eerst voor de jongens pogingen hadden aangewend om ze bij de stadsreiniging in een ondergeschikte betrekking geplaatst te krijgen en dit mislukt was omdat de toenmalige directeur 'menschen met intellect moest hebben', meenden we pogingen bij het Gemeentebestuur te moeten doen voor het tot stand komen van handwerkcursussen, waartoe we in 1909 verlof kregen. Voorlopig kregen we verlof tot het oprichten van een schoenmakerscursus, in 1911 gevolgd door een boekbinderscursus..." ${ }^{94}$
\end{abstract}

Het doel van deze cursussen was, om de beste mannelijke oud-leerlingen van het BLO voldoende vakkennis bij te brengen om als zelfstandig ambachtsman een bestaan op te kunnen bouwen. ${ }^{95} \mathrm{Er}$ waren twee cursussen, in boekbinden en in schoenmaken. Het was de bedoeling dat het aanbod in de loop van de tijd uitgebreid zou worden en dat het uiteindelijk tot een zelfstandige ambachtsschool voor zwakzinnigen zou komen. ${ }^{96}$

De oprichters wisten dat lang niet alle oud-leerlingen van de Rotterdamse scholen voor BLO de ambachtscursussen zouden kunnen volgen. Allereerst vielen de meisjes af. Die moesten door anderen geholpen worden:

"Velen zijn geschikt te maken voor naaister, strijkster of het behandelen der wasch; enkelen kunnen voor dienstbode worden opgeleid. ${ }^{97}$

En dan was er nog de grote groep jongens, die een te grote verstandelijke beperking had om voor de cursussen in aanmerking te komen. Ook zij waren op de hulp van anderen aangewezen:

"Natuurlijk blijft er nog een leger over van hen, waarvoor de Maatschappij geen plaats biedt. Maar als vanzelf zal ook voor dezen raad geschaft moeten worden. Een groot deel van hen, en zeker niet het minste deel, zal blijken geschikt te zijn, onder goede leiding arbeid te verrichten, en het lijdt geen twijfel, dat in de groote centra, waar deze zich ophoopen, daarvoor gelegenheid geboden zal moeten worden. Het gevolg zal wezen, dat men voor dezen werkhuizen zal oprichten, waar allerlei arbeid verricht kan worden, die door den arbeider van den tegenwoordigen tijd niet dan met tegenzin gedaan wordt. ${ }^{98}$

Zij zouden een beroep kunnen doen op de vereniging Zorg voor het Achterlijke Kind opgericht, die echter, net als de in de vorige paragraaf aangehaalde Commissie ter Behartiging der Belangen van Leerlingen en Oud-leerlingen der Buitengewone Scholen voor Lager Onderwijs door gebrek aan middelen vrijwel niet functioneerde en zich bovendien vooral richtte op de oud-leerlingen van de ambachtscursussen. ${ }^{99}$

Uiteindelijk bleek het experiment met voortgezette opleiding een doodlopende weg. Leerlingen bereikten vrijwel nooit het beoogde niveau van zelfstandig functionerend ambachtsman. In 1924 werd er onderzoek gedaan naar de 
resultaten van de cursussen. Daaruit bleek dat van de 77 onderzochte oudleerlingen er 16 in een geschoold beroep terecht waren gekomen. Van hen verdiende slechts de helft een loon dat hoog genoeg was om zichzelf en een eventueel gezin te kunnen onderhouden. En van hen was er slechts één, die werkte in het vak waarvoor hij was opgeleid. Alle andere oud-leerlingen van de ambachtscursussen werkten in een beroep waarvoor weinig of geen scholing nodig was. ${ }^{100}$ Het leidde tot de conclusie dat de ambachtscursussen niet voldeden en bovendien slechts aan een beperkt deel van de oud-leerlingen van het BLO plaats bood. Ze vonden verder geen navolging. Begin 1934 zette de gemeente Rotterdam de subsidie voor de cursussen stop en werd dit experiment definitief gestaakt. $^{101}$

\subsubsection{Centrale Vereniging ter Behartiging van de Belangen van Zwakzinni- gen}

Aan het begin van de jaren tien waren vanuit deze vereniging, waarvan ik het ontstaan in paragraaf 1.1. heb behandeld, in enkele plaatselijke afdelingen opgericht die zich op verschillende manieren met zwakzinnigen bezighielden. Daarbij koos men vaak oud-leerlingen van het BLO als concrete doelgroep.

De afdeling Dordrecht functioneerde daarbij vanaf de oprichting in 1911 feitelijk als ondersteuningsorganisatie van de plaatselijke school voor BLO ${ }^{102}$ Een van de doelen van de afdeling was,

“... steun te verleenen aan de ex-leerlingen der Buitengewone School voor Lager Onderwijs (voor Zwakzinnigen) alhier, zoodra zij die School zullen hebben verlaten

Omdat deze organisatie onafhankelijk van de landelijke vereniging functioneerde zal ik de geschiedenis van deze organisatie verder apart behandelen in de paragrafen 2.4.4 en 2.4.5.

In Groningen was op 1 maart 1913 een afdeling van de vereniging opgericht. Lid van de afdeling waren onder andere de criminoloog S. van Mesdag en de schoolarts A. van Voorthuijsen. Door geldgebrek was het de eerste jaren niet mogelijk met hulp aan de doelgroep te beginnen. ${ }^{103}$ Pas in 1915, toen de school voor BLO de deuren opende, kwam men tot daadwerkelijke activiteiten. Er werd een commissie tot het verleenen van steun aan leerlingen van de buitengewone school in het leven geroepen, die tot doel had vooral kinderen uit arme gezinnen te ondersteunen, vooral op het moment dat zij de school verlieten. ${ }^{104}$ In hoeverre deze commissie heeft gefunctioneerd en wat haar activiteiten precies waren tussen 1915 en 1929 is niet meer te achterhalen. ${ }^{105}$ In 1930 werd de afdeling verzelfstandigd tot de Vereeniging Zwakzinnigenzorg, die een werkinrichting voor zwakzinnigen oprichtte $^{106}$ en verder binnen de Nederlandse nazorg een volstrekt eigen rol zou spelen.

De Arnhemse afdeling werd in de loop van 1913 opgericht. Secretaris werd A.J. Schreuder, directeur van het medisch-pedagogische 'Klein Warnsborn' voor 'meergegoede zwakzinnigen' ${ }^{\text {107 }}$. In 1914 werd een consultatiebureau opgericht. Men besloot om de ontslagen oud-leerlingen van de school voor BLO bij dit bureau in te schrijven en zodoende een begin te maken met de registratie van 
zwakzinnigen. ${ }^{108}$ Het doel van het consultatiebureau werd aangegeven:

"... het wil een vraagbaak zijn voor allen, die met zwakzinnigen te doen hebben en daarbij moeilikheden ondervinden." ${ }^{109}$

In 1915 bezochten 33 cliënten het consultatiebureau. De helft daarvan bestond uit leerlingen en oud-leerlingen van de school voor BLO. ${ }^{110}$ In 1916 trad Fr. Visser, directeur van de J.P.Heije-Stichting, net als Klein-Warnsborn een internaat voor betergesitueerde zwakzinnigen, toe als lid. A.J. Schreuder stelde in dat jaar voor om het kaartregister van leerlingen en oud-leerlingen van het BLO uit te breiden tot een landelijk registratiesysteem. ${ }^{111}$ In totaal bezochten in 191620 personen het consultatiebureau. ${ }^{112}$ Over de verdere gang van zaken van deze Arnhemse afdeling na 1916 is niets bekend.

In Amsterdam werden in 1911 de eerste stappen gezet voor een afdeling. Hierbij was onder andere de psychiater L. Bouman betrokken. In 1913 werd begonnen met een consultatiebureau, dat één avond per week geopend was. ${ }^{113}$ Begin 1914 werd de afdeling door de gemeente erkend en kwam in aanmerking voor subsidie, maar door het uitbreken van de Eerste Wereldoorlog moest men de activiteiten tijdelijk staken. Onder de 40 cliënten waarmee men in 1914 te maken kreeg waren 2 lijders aan 'debilitas mentis' en 11 aan 'imbecillitas', verder 14 psychopathen. Men onderhield goede relaties met de gezondheidsdienst, een voorloper van de GG\&GD. ${ }^{114}$ In maart 1915 werden de activiteiten van het consultatiebureau opnieuw gestart en kreeg dat jaar nog met 43 cliënten te maken. ${ }^{115}$ Ook deze afdeling verdween na 1915 uit het zicht.

In de loop van 1917 ging de Centrale Vereeniging ter Behartiging van de Belangen van Zwakzinnigen, waarschijnlijk als gevolg van een gebrek aan middelen tijdens de Eerste Wereldoorlog, financieel ten onder. Alleen de afdelingen van de vereniging die een voldoende groot plaatselijk draagvlak hadden georganiseerd en zich verbonden hadden aan een school voor BLO bleven bestaan. Dat was met zekerheid zo in Dordrecht en Groningen, waar de afdelingen zich verzelfstandigden tot onafhankelijke rechtspersonen. In hoeverre dat ook het geval was in Arnhem is niet na te gaan, omdat de archieven van de nazorg in de Tweede Wereldoorlog verloren zijn gegaan. En ook van de Amsterdamse afdeling zijn na 1915 geen sporen meer te vinden. Uiteindelijk werd de Centrale Vereniging overgenomen door de psychiater F.S. Meijers, die ze in 1924 omvormde tot de Centrale Vereeniging ter Behartiging van de Maatschappelijke Belangen van Zenuw-en Zielszieken. ${ }^{116}$

\subsubsection{Avondonderwijs}

In het gewone lager onderwijs in Nederland bestond de mogelijkheid voor kinderen die ouder waren dan dertien jaar en dus niet langer leerplichtig, om na hun werk avondonderwijs te volgen. Zo konden zij zich, als ze dat wilden, verder ontwikkelen terwijl ze overdag werkten. In het BLO vond men, dat ook aan de oudleerlingen van het buitengewoon onderwijs een dergelijke mogelijkheid moest worden geboden. In 1912 werd hiermee een proef gestart in Den Haag, dat herhalingsonderwijs werd genoemd. ${ }^{117}$ P.H. Schreuder, het hoofd van de eerste Haagse school voor BLO, beschouwde de proef als geslaagd en het herhalingsonderwijs werd in de daaropvolgende jaren voortgezet. ${ }^{118}$ 
In Dordrecht werd in 1917 met avondonderwijs begonnen, nadat in 1916 de eerste leerlingen de school voor BLO verlaten hadden. Het afdelingsbestuur van de Centrale Vereeniging ter Behartiging van de Belangen van Zwakzinnigen gaf het hoofd van de school, A.H.D. Wepster, de vrije hand om deze zorg in te vullen. ${ }^{119} \mathrm{Hij}$ koos voor herhalingsonderwijs, waarin de nadruk vooral op de instandhouding en uitbreiding van de schoolse kennis lag. ${ }^{120}$ Het onderwijs werd zó gepland, dat oud-leerlingen op doordeweekse avonden weinig vrije tijd overhielden. $^{121}$

Ook in Haarlem werd vanaf 1918 geëxperimenteerd met herhalingsonderwijs. Oud-leerlingen van het BLO werden samengebracht met kinderen uit het reguliere onderwijs die van een vergelijkbaar intellectueel niveau zouden zijn. Dat bleek niet goed uit te pakken, tussen de beide groepen ontstonden conflicten. Vanaf 1921 werd speciaal herhalingsonderwijs alleen nog maar aan de oud-leerlingen van het BLO gegeven. ${ }^{122}$

Uiteindelijk bleek dat de nadruk op het bijbrengen van schoolse kennis niet de beste keuze was, als men tenminste zoveel mogelijk oud-leerlingen van het BLO wilde bereiken. Later in de jaren twintig zou de nadruk vooral op gezelligheid komen te liggen. Het doel van avondonderwijs, dat uiteindelijk avondverzorging zou worden genoemd, verschoof van het lesgeven naar het zoveel mogelijk beheersen van de vrije tijd van oud-leerlingen van het BLO.

Dat hing enerzijds samen met een algemene zorg in Nederland over 'de' jeugd, vooral de jeugd die niet langer de school volgde. Er was zelfs een speciale staatscommissie ingesteld om hun problematiek te onderzoeken, die in 1919 verslag uitbracht. Men constateerde dat er een groot gebrek aan vorming voor de jeugd tussen 13 en 18 jaar bestond. Het leidde ertoe, dat het jongerenwerk, georganiseerd vanuit de verschillende zuilen, een hoge vlucht nam. In 1939 waren er zo'n 250 jeugdorganisaties in Nederland met in totaal zo'n 750.000 leden. ${ }^{123}$

Anderzijds had het te maken met de angst voor de slechte aanleg van lichtzwakzinnigen. Voorkomen moest worden dat zij zich overgaven aan risicovol gedrag zoals straatslenteren, snoepen, bioscoopbezoek en andere stedelijke verleidingen waardoor ze maatschappelijk zouden kunnen afglijden. Aan deze groep moesten gecontroleerde ontspanningsmogelijkheden geboden worden, ook omdat zij vaak niet terechtkonden in het reguliere jongerenwerk.

\subsubsection{Aangepaste arbeid}

De zorg voor oud-leerlingen van het BLO was in Dordrecht aan Wepster, het hoofd der school, opgedragen. Een onderdeel daarvan bestond uit het zoeken van werk. Dat ging in de meeste gevallen goed, maar halverwege de jaren tien werd hij geconfronteerd met enkele pupillen voor wie hij geen geschikte arbeid kon vinden.

"...met vreugde kon geconstateerd worden, dat verreweg het grootste gedeelte (van de oud-leerlingen, LB) in staat bleek, zich in de maatschappij te handhaven; sommigen zeer goed, anderen minder.

Een viertal evenwel was het leven in fabriek of werkplaats te machtig. Geplaagd en onbegrepen dwaalden zij rond. 
Voor hen moest, zoo meende het bestuur der vereeniging Zwakzinnigenzorg, als het kon, toch iets gedaan worden. Te goed als zij waren om doelloos rond te loopen.

De Vereeniging vatte dan ook het plan op, hen onder toezicht eenvoudigen arbeid te laten verrichten. ${ }^{\text {"124 }}$

Wepster legde in 1917 een concreet voorstel voor aan het Dordtse afdelingsbestuur van de Centrale Vereeniging ter Behartiging van de Maatschappelijke Belangen van $Z$ wakzinnigen om aan deze oud-leerlingen arbeid te verschaffen. Dat besloot,

“...om (...) aan enkele ex-leerlingen, die feitelijk niet in de maatschappij zonder verdere hulp vooruit kunnen komen of zelfs zich maar kunnen handhaven, in het Slöjdlokaal (handenarbeidlokaal, LB) op de school onder toezicht de gelegenheid te geven eenig handwerk te verrichten, wat hun vooraf zou moeten worden geleerd en waarmee ze dan althans eenigermate in hun onderhoud zouden kunnen voorzien; bedoeld wordt: het vlechten van matten en van het matwerk in stoelen, het knoopen van netten, enz..125

In 1919 werd met een proef begonnen, waarbij twee oud-leerlingen onder toezicht biezen matten konden vlechten. Deze proef beviel goed en het afdelingsbestuur besloot om te gaan werken aan een zelfstandige werkinrichting voor oud-leerlingen van het BLO.

"De resultaten waren zoo bemoedigend, dat het Bestuur vrijheid vond, zich verder voor de zaak te interesseeren, en te trachten, een zelfstandige werkinrichting te stichten.

Waar tot nu toe buiten de gestichten in Nederland geen inrichting van dezen aard bestond, werd terecht besloten, voorloopig een proef ter nemen voor een paar jaar." ${ }^{126}$

Er werden fondsen geworven. Enkele vermogende ingezetenen van Dordrecht doneerden een bedrag, de gemeente Dordrecht stelde gratis ruimte beschikbaar en bij enkele particuliere organisaties werd subsidie aangevraagd. Eén van de organisaties die subsidie verleende was de Vereeniging Maatschappelijk Werk bij Zenuwlijden en Krankzinnigheid, die in 1917 was opgericht door de beide inspecteurs van het krankzinnigenwezen, J.H. Schuurmans Stekhoven en W.M. van der Scheer. Deze organisatie had in verschillende plaatsen in het land afdelingen opgericht voor materiële en morele steun aan psychiatrische patiënten in de maatschappij. Tegelijkertijd had deze vereniging landgoederen opgekocht om daarop kolonies te stichten waar gestichtsbewoners, die weinig hulp nodig hadden maar toch niet zelfstandig in de maatschappij kondenverblijven, relatief goedkoop ondergebracht zouden kunnen worden. ${ }^{127}$ De vereniging, die ook zwakzinnigen tot haar doelgroep rekende, vond het initiatief van Wepster zó belangrijk, dat zij een substantieel deel van de oprichtingskosten voor haar rekening nam. ${ }^{128}$ Hierdoor kon op 6 juni 1920 het externaat voor psychisch invaliden geopend worden. ${ }^{129}$

Aanvankelijk werkten er vier oud-leerlingen. In totaal zouden er tussen 1920 en 192316 personen tewerkgesteld worden.

"Aan de ouders of verzorgers der I.I. trachten wij duidelijk te maken, dat het doel onzer inrichting is aan diepstaande zwakzinnigen nuttige bezigheid en geregelden arbeid te verschaffen, met als verwijderd doel het aanleeren van een een- 
voudig vak, waardoor zij uit gestichten en van de straat gehouden worden. Ter aanmoediging ontvingen zij iedere week zakgeld, dat afhankelijk is van het geproduceerde." 130

Daarmee was de eerste werkinrichting voor oud-leerlingen van het BLO een feit geworden. De keuze hiervoor kwam deels voort uit de lange traditie van tewerkstelling van hulpbehoevenden die Nederland in 1920 al kende. Vanaf het einde van de achttiende eeuw hadden er veel werkhuizen bestaan, waar armen werkten in ruil voor onderdak en inkomen en zo moesten leren om door middel van arbeid in hun eigen onderhoud te voorzien. Probleem van de werkhuizen was echter dat zij zichzelf moesten bedruipen. Dat is geen enkel werkhuis ooit voor langere tijd gelukt, waardoor ze allemaal, na langere of kortere duur, werden opgeheven. ${ }^{131}$

Ook in de krankzinnigengestichten werden patiënten in werkplaatsen tewerkgesteld. Dat gebeurde in het kader van hun behandeling en werd arbeidstherapie genoemd. Het was niet de bedoeling, dat deze werkplaatsen kostendekkend werkten. De opbrengst van de producten werd gebruikt om de verpleegkosten omlaag te brengen, maar winst hoefde er niet gemaakt te worden.

Het vernieuwende van Wepsters aanpak bestond uit de combinatie van elementen van beide vormen van tewerkstelling: in de samenleving maar zonder kostendekkend te hoeven werken. Hij noemde zijn werkinrichting externaat, de bedoeling was dat door dagbesteding oud-leerlingen van het BLO die niet in loondienst konden werken thuis konden blijven wonen en niet naar een gesticht hoefden te worden overgebracht.

Dat laatste was meteen het belangrijkste argument waarmee de gemeente Dordrecht werd overgehaald om het project te subsidiëren. Gemeenten waren in die tijd financieel verantwoordelijk voor de kosten van het onderbrengen van armlastige bewoners in gestichten. Door de werkinrichting, zo stelde Wepster, kon de gestichtsplaatsing van oud-leerlingen van het BLO die niet tot arbeid in loondienst in staat waren worden voorkomen. Door geld aan de werkinrichting te besteden, konden daarmee de veel hogere kosten worden voorkomen. Later zouden er in veel meer plaatsen werkinrichtingen voor oud-leerlingen van het BLO gesticht worden. Het zou uitgroeien tot één van de belangrijkste onderdelen van de nazorg. 

Keuze voor professionalisering

Amsterdam 1917-1924

\begin{abstract}
"Slechts hij zal in dit werk slagen, die is bezield door hetzelfde heilig vuur dat zij zoo bewonderen in enkelen van het personeel der scholen."
\end{abstract}

After-Care rapport $1917^{132}$

In dit hoofdstuk behandel ik het ontstaan van de professionele nazorg in Amsterdam en de eerste jaren van het bestaan ervan, de periode waarin deze nieuwe vorm van zorg zich moest bewijzen.

In de eerste paragraaf ga ik in op een aantal onderzoeken die aan het begin van de jaren tien van de twintigste eeuw naar de toestand van de oud-leerlingen van het BLO werden gedaan. Daarna behandel ik in paragraaf twee het rapport uit 1917 dat de aanzet gaf tot de professionalisering van de Amsterdamse zorg voor oudleerlingen van het BLO. In de derde paragraaf bespreek ik de eerste jaren dat de professionele nazorg functioneerde. Daarna ga ik in op de wijze waarop deze zorg in het gemeentelijke apparaat werd opgenomen. Ik sluit af met het ontstaan van de Amsterdamse werkinrichting.

Bij de onderzoeksvragen komt vooral de vraag naar de werkwijzen van de nazorg aan de orde, omdat deze voor een belangrijk deel ontwikkeld werden in de eerste periode dat de professionele nazorg in Amsterdam bestond. Ook komt, vooral in de tweede paragraaf, het denken over zwakzinnigheid aan de orde. Aan het einde besteed ik aandacht aan de relatie tussen nazorg, BLO en andere hulpvormen.

\title{
3.1 Oud-leerlingen gevolgd
}

Het BLO in Amsterdam had in vergelijking met het openbare BLO in de rest van Nederland een bijzondere positie. De scholen voor BLO werden in de hoofdstad beheerd door de Vereeniging voor Spraakgebrekkige en Achterlijke Kinderen, die geheel door de gemeente Amsterdam gesubsidieerd werd. Formeel was er geen sprake van openbaar onderwijs, maar van bijzonder neutraal BLO. Door deze constructie viel het Amsterdamse BLO buiten elk wettelijk kader en kon het in alle vrijheid beslissen hoe het onderwijs aan zwakzinnige kinderen ingevuld diende te worden. ${ }^{133} \mathrm{Het}$ was wel uitdrukkelijk de bedoeling, dat de scholen voor BLO door de gemeente Amsterdam zouden worden overgenomen, als deze experimentele fase achter de rug was. Dat zou uiteindelijk in 1923 gebeuren. ${ }^{134}$

De oud-leerlingen die in Amsterdam de scholen voor BLO verlieten werden angstvallig in het oog gehouden. Aan het begin van de jaren tien werd een aantal onderzoeken uitgevoerd naar hun levensomstandigheden. Hieruit moest blijken, in hoeverre het BLO er in slaagde haar leerlingen door middel van aangepast onderwijs voor te bereiden op een zelfstandig bestaan in de maatschappij. Dat werd erg belangrijk gevonden, omdat het bestaansrecht van deze nog jonge vorm van onderwijs er van afhing.

Aanvankelijk werd er zeer positief gerapporteerd over de oud-leerlingen. J. 
Schreuder, hoofd van School 2 voor BLO, schreef in zijn verslag aan Rijk en Gemeente over 1911:

"Waar er echter voor onze oud-leerlingen reeds velen zijn, die den leeftijd van 18 jaar en ouder bereikt hebben, die de voor hen zoo gevaarlijke puberteit te boven zijn behoeft ook voor de jongeren onder hen niet zoo heel veel vrees gekoesterd te worden. Het is nu reeds gebleken, dat geschikte arbeid hen voor veel ellende behoedt." 135

Uit onderzoek, dat in dat jaar werd gehouden, bleek dat van de 85 kinderen, die vóór 1911 School 2 hadden verlaten, er 65 als geslaagd werden beschouwd. Dat hield in, dat zij in loondienst werkten. Onder de 17 oud-leerlingen die niet als geslaagd beschouwd werden, die niet in loondienst werkten, werden er vier als gevaarlijk voor de maatschappij beschouwd. ${ }^{136}$ Toen het onderzoek naar de oudleerlingen een jaar later, in 1912, herhaald werd, lag het slagingspercentage van de oud-leerlingen van School 2 nog steeds rond de tachtig procent. Van de nietgeslaagden verbleef er één in een gesticht, een ander was, als stadsbestedeling, op kosten van de gemeente in een pleeggezin op het platteland ondergebracht.

In 1912 werd er ook op School 1 onderzoek gedaan naar de oudleerlingen. Hier hadden vanaf de start van de school in 1899124 kinderen de school verlaten. Van hen werden er 24 als maatschappelijk ongeschikt beschouwd. Ook hier werd $80 \%$ van de oud-leerlingen als geslaagd beschouwd. Voor Boorsma, de directeur van deze school, leidde dat tot de conclusie dat het Buitengewoon Onderwijs zich definitief bewezen had.

"Reeds nu is dus het bewijs geleverd, dat de scholen voor het B.O. nog wat anders kunnen zijn, dan een plaats, waar het remmend element van de L.S. bijeengebracht moet worden, en dat zij in staat zijn deze misdeelde kinderen tot menschen te vormen, die in plaats van parasiteeren op de maatschappij een bescheiden plaatsje in de maatschappij waard zijn." ${ }^{\text {138 }}$

Waarschijnlijk is de wens de vader van de gedachte geweest, want een onderzoek dat het daaropvolgende jaar, in 1913, op School 3 voor het BLO werd gehouden gaf een heel wat minder positief beeld te zien. De toestand van 36 oud-leerlingen werd toen nader bekeken. Hiervan werkten er 18 in loondienst en 5 in de huishouding thuis. Deze 23 werden als geslaagd beschouwd, de overigen niet. Het slagingspercentage van $65 \%$ was aanzienlijk lager dan bij de twee andere scholen voor BLO in de voorafgaande jaren. Van de dertien oud-leerlingen die niet als geslaagd werden beschouwd, verbleven er acht in een gesticht. Vijf van hen woonden thuis maar zouden eigenlijk naar een gesticht moeten worden overgebracht. ${ }^{139}$ De oorzaak voor dit verschil werd vooral gezocht in het feit, dat School 3 in een 'sociaal zwakke wijk' stond, waardoor de meeste leerlingen uit de allerlaagste sociale klassen afkomstig waren.

\subsection{Het after-care rapport}

De problematiek van de oud-leerlingen van het BLO in Amsterdam werd in de loop van de tijd ernstiger. Om de aard en omvang ervan in kaart te brengen en mogelijke oplossingen aan te reiken, besloot de Vereeniging voor Spraakgebrekkige en Achterlijke Kinderen een commissie in te stellen die hierover rapport moest uitbren- 
gen. ${ }^{140}$ Deze commissie bestond uit drie leden. Voorzitter was K.H. Bouman, voorzitter van de vereniging en hoogleraar psychiatrie en neurologie aan de Universiteit van Amsterdam, J. Gewin, schoolarts bij het reguliere lager onderwijs en D. Herderschêe, schoolarts bij het BLO. Zij brachten in 1917 het Rapport van de Commissie tot het bestudeeren van het vraagstuk der 'Aftercare' (maatschappelijke zorg) ingesteld door het Bestuur der Vereeniging voor Spraakgebrekkige en Achterlijke Kinderen uit, dat bekend zou worden onder de kortere naam After-CareRapport. ${ }^{141}$

Uitgangspunt van de commissie was, dat het BLO zich nadrukkelijk behoorde te richten op het maatschappelijk geschikt maken van haar leerlingen.

"Voor het buitengewone onderwijs is de Maatschappelijke zelfstandigheid niet vanzelfsprekend en deze moet steeds als direct doel voor oogen gehouden worden: 'Non Scholae, sed vitae discimus' (Niet voor de school, doch voor het leven leren wij, LB). ${ }^{142}$

De commissie vond dat er na het doorlopen van de school nog een of andere vorm van zorg behoorde te zijn om zeker te stellen dat de oud-leerlingen in de maatschappij op het rechte pad zouden blijven. Dat was zowel in het belang van de maatschappij, van de school als van de betrokken oud-leerling.

"Indien de overheid of de vereeniging die de school voor buitengewoon onderwijs
in stand houdt, haar bemoeiingen uitsluitend beperkt tot den schoolleeftijd en zich
daarna niets meer aan de kinderen laat gelegen liggen, dan zal in de eerste
plaats totaal ontbreken de voor de evolutie van den schoolarbeid onmisbare er-
varing omtrent het bereiken van het gewenste maatschappelijke doel. Men kan er
echter van verzekerd zijn, dat het resultaat in dit geval niet zoo groot mogelijk zal
zijn."

De commissie gaf aan, dat oud-leerlingen van het BLO zwakker in de maatschappij stonden dan hun leeftijdsgenoten die het gewone lager onderwijs hadden gevolgd. Dat had volgens haar vooral te maken met de abnormale hersenfunctie van de leerlingen van het BLO. Dat was volgens de commissie een blijvende staat en geen geneesbare ziekte: 'Eens zwakzinnig, altijd zwakzinnig!' was haar uitgangspunt. ${ }^{144}$ Door dit gegeven zouden oud-leerlingen van het BLO niet goed opgewassen zijn tegen de maatschappelijke realiteit waarmee ze na hun schooltijd geconfronteerd werden, zeker in vergelijking met normale kinderen,

"...want, ondanks de beste opvoeding zal bij achterlijke kinderen, het aanpassingsvermogen aan nieuwe levensomstandigheden, steeds beneden het normale blijven." 145

Vervolgens beschreef de commissie hoe de zorg voor oud-leerlingen van het BLO tot dan toe was georganiseerd. Daarbij stelde de commissie vast, dat de onderwijzeressen en de onderwijzers heel veel voor hun oud-leerlingen deden en hielpen waar ze konden, maar dat dat, ondanks alle goede bedoelingen, toch niet voldoende was. ${ }^{146}$ Vooral bij het zetten van de eerste schreden op de arbeidsmarkt zou meer en betere hulp beschikbaar moeten zijn.

"Dat werkelijke hulp, verleend voor het verkrijgen van het eerste baantje, geheel onvoldoende is, kan blijken uit het feit, dat betrekkelijk weinig kinderen lang in die eerste betrekking blijven; dan staat het kind of zijn vaak eveneens abnormale ou- 
ders, weer voor dezelfde moeilijkheid als bij het verlaten der school, en wie helpt hen dan?" 147

Om te kunnen beoordelen, in hoeverre oud-leerlingen daadwerkelijk hulp nodig hadden, deed de commissie onderzoek naar 133 jongens, die minstens vijf jaar eerder een Amsterdamse school voor BLO hadden verlaten. Daarbij werd niet alleen gekeken naar de vraag, of iemand al dan niet in loondienst werkte, maar ook hoe vaak de betrokken oud-leerling van arbeidsplaats gewisseld was. Uit dit onderzoek kwam naar voren, dat van de 133 onderzochten er nog maar 27 bij hun eerste baas werkten, die in 11 van de gevallen hun eigen vader was. Alle 105 anderen waren minstens éénmaal van betrekking gewisseld.

"De reden tot verandering was ongeveer even vaak ontevredenheid van het kind of de ouders, alswel ongeschiktheid van de leerling, hetzij door onhandigheid, hetzij door brutaliteit of moeilijkheden met de medewerklieden. ${ }^{.148}$

Een deel van de oud-leerlingen deed bij problemen, of deze nu met hun werk te maken hadden of met andere zaken, een beroep op de onderwijzers van hun oude school. Meestal werden zij door het hoofd der school verder geholpen. ${ }^{149}$ Maar lang niet alle oud-leerlingen zetten deze stap en stonden er daardoor alleen voor. ${ }^{150}$

De conclusie die de commissie uit dit onderzoek trok, was dat de hulp die de onderwijzers van het BLO aan hun oud-leerlingen boden niet voldoende was. Daarom pleitte zij ervoor om een persoon aan te stellen die zich speciaal met deze zorg moest bezighouden en actief oud-leerlingen benaderde. ${ }^{151}$ De commissie vond het, in het belang van de hulpverlening, noodzakelijk dat een dergelijk persoon groot overwicht over zijn pupillen zou hebben.

" Dit overwicht van den mentor wordt niet weinig versterkt, wanneer deze den jongen man uit een of andere moeilijkheid heeft weten te helpen en daartoe bestaat al te vaak gelegenheid, wanneer diefstal, brutaliteit, een enkele maal dronkenschap, ontslag of hechtenis doet dreigen of wanneer conflicten onder dienst hen achter slot brengen." 152

Op School 1 voor BLO was een proef genomen, waarbij het schoolhoofd Boorsma zich intensief had beziggehouden met de zorg voor oud-leerlingen. Hij had er zich op toegelegd tijdig in te grijpen als het mis dreigde te gaan.

"Zoveel mogelijk worden ontslagen leerlingen direct aan werk geholpen en aan het werk gehouden. Dreigde een conflict met Justitie dan stond de heer Boorsma op de bres en vervolging werd voorkomen of voorwaardelijke invrijheidsstelling volgde. Gedroeg een kind zich te zeer onmaatschappelijk, dan werd door tijdig opnemen in een gesticht de anti-sociale daad vaak voorkomen. Ook gelukte het een onzer directeuren eenige malen, een meisje weer in het rechte spoor te leiden, toen hij bemerkte, dat het den breeden weg op dreigde te gaan enz. enz." ${ }^{153}$

De commissie vond op grond van deze ervaringen dat het onderwijzend personeel van het BLO het meest geschikt was om de zorg aan oud-leerlingen uit te voeren. Zij hadden het vertrouwen van hun pupillen en konden daardoor voldoende gezag over hen uitoefenen. Tegelijkertijd zag de commissie in dat hieraan ook bezwaren kleefden, omdat onderwijzers niet over voldoende kennis en ervaring op maatschappelijke vlak beschikten om hun oud-leerlingen goed te kunnen helpen: 
"Voor de regeling van de Maatschappelijke zorg is naast kennis van het achterlijke kind noodig: kennis van de arbeidsmarkt, vertrouwdheid met arbeidstoestanden, het voeling houden met het gezin van den leerling, met zijn werkgevers, ervaringen van de werking van verschillende maatschappelijkpaedagogische instellingen, contact met rechter en dokter en nog zoveel andere dingen. Veel tijd zal daarvoor beschikbaar moeten zijn, die eenvoudig buiten de schooluren alleen niet gevonden kan worden. ${ }^{154}$

Het opbouwen van deze specifieke kennis en ervaring achtte de commissie niet te combineren met het onderwijzerschap. Men wilde daarom dat er een ambtenaar voor de maatschappelijke zorg zou worden aangesteld, die zich uitsluitend met de zorg voor oud-leerlingen van het BLO zou bezighouden. Hij zou een salaris moeten krijgen dat gelijk stond aan dat van de directeuren van de scholen voor BLO ${ }^{155}$ Dat was belangrijk, omdat mét dat salaris ook de bijbehorende sociale status kwam, die van belang werd geacht voor het overwicht dat de ambtenaar over zijn pupillen en hun ouders moest hebben.

Aan de ambtenaar voor de maatschappelijke zorg mochten hoge eisen gesteld worden. Hij moest over een krachtige persoonlijkheid beschikken en zijn sporen hebben verdiend in het BLO-onderwijs. ${ }^{156}$ De rol van de ambtenaar werd nadrukkelijk in het verlengde van het onderwijs geplaatst. De commissie zag de maatschappelijke zorg als de kroon op het werk van de school voor BLO.

"Onderwijs is voor den zwakzinnige belangrijk, opvoeding belangrijker, 'Maatschappelijke zorg' het belangrijkst. Slechts door de 'Maatschappelijke zorg' kan het kapitaal door onderwijs en opvoeding verzameld, rentegevend worden gemaakt." ${ }^{157}$

De taak van de ambtenaar voor de maatschappelijke zorg zag de commissie als volgt:

"Hij zal door zijn voorzorgsmaatregelen de maatschappij trachten te beveiligen tegen de a- of anti-sociale daden van den zwakzinnige. Maar tevens zal hij den zwakzinnige trachten te beveiligen tegen de gevaren, die hem van de kant der maatschappij bedreigen." ${ }^{158}$

Daarbij moest nauw met de school worden samengewerkt, omdat het doel met dat van de maatschappelijke zorg samenviel:

"Het doel van school en ambtenaar is, het sociaal weerbaar maken van den zwakzinnige. Beiden zullen trachten den zwakzinnige te brengen tot een werkzaam, productief leven; als het kan in de maatschappij, als het moet in een inrichting. ${ }^{159}$

In de praktijk betekende dat, dat de ambtenaar met de scholen voor BLO alle mogelijke informatie moest uitwisselen om de overgang van de leerlingen van school naar maatschappelijke zorg zo soepel mogelijk te laten verlopen.. Ook moest de ambtenaar, al voordat een leerling de school verliet, diens sociale omgeving hebben bezocht. ${ }^{160}$

Over de wijze waarop de ambtenaar voor de maatschappelijke zorg zijn werk moest invullen werden weinig concrete aanbevelingen gedaan. De comissie beval aan, dat de ambtenaar twee avonden per week op verschillende scholen een spreekuur zou houden en dat het bestuur van de vereniging erkenning zou 
aanvragen om als reclasseringsinstelling te kunnen optreden. ${ }^{161}$ De rest werd overgelaten aan de nog aan te stellen ambtenaar. Dat maakte duidelijk dat het om een échte pioniersbaan ging.

De commissie ging in haar rapport verder in op de vraag, in hoeverre oudleerlingen van het BLO een gevaar voor de maatschappij betekenden. De commissie beschouwde zwakzinnigen als een risico voor de samenleving vanwege hun slechte aanleg, maar was tegelijkertijd overtuigd van de kracht van de pedagogiek om hen op het rechte pad te houden.

" Veel bijdragen tot het productievermogen zullen onze oud-leerlingen wel nooit, maar wat door opvoeding en maatschappelijke zorg bereikt kan worden is voor beiden als winst te beschouwen. Goddard zegt: 'The Feebleminded are potential paupers, criminals, prostitutes and drunkards." ${ }^{162}$

De auteurs van het after-care-rapport haalden enkele Engelse en Amerikaanse statistieken aan om het risico van zwakzinnigen in de maatschappij te illustreren. Hieruit zou blijken dat, gemeten met de test van Binet en Simon, de helft van de jeugdige misdadigers in die landen zwakzinnig was. ${ }^{163} \mathrm{Om}$ te kunnen beoordelen, in hoeverre oud-leerlingen van het BLO in Nederland een gevaar voor de samenleving inhielden, had de commissie een onderzoek gedaan onder 288 oud-leerlingen van de scholen 1 en 3 voor BLO. Van 202 oud-leerlingen kon de toenmalige verblijfplaats worden achterhaald (zie tabel 1).

Tabel 1

Situatie van 202 oud-leerlingen van school 1 en 3 voor het BLO te Amsterdam, $1917^{164}$

\begin{tabular}{lll}
\hline Situatie & Jongens & Meisjes \\
& $\mathbf{N}=\mathbf{1 4 5}$ & $\mathbf{N}=\mathbf{5 7}$ \\
Werkzaam in de maatschappij & 113 & 20 \\
Thuis werkzaam of gehuwd & - & 10 \\
Thuis verpleegd (later asyl & 4 & 15 \\
@istitgiven & 7 & 4 \\
Vagebondage & 2 & - \\
In gesticht & 19 & 8 \\
\hline
\end{tabular}

Uit deze cijfers komt naar voren, dat slechts twee oud-leerlingen op het slechte pad waren terechtgekomen. Dat was zó'n laag aantal en zo weinig in lijn met het beeld dat van zwakzinnigen bestond, dat de commissie zich in eerste instantie afvroeg of alle oud-leerlingen wel écht zwakzinnig waren, maar ze moest al direct vaststellen dat dat inderdaad het geval was.

Tegelijkertijd werd onderzocht, welke beroepen de 35 oud-leerlingen uitoefenden, die al langer dan 10 jaar tevoren de school hadden verlaten. Dat bleek vooral ongeschoolde arbeid te zijn in uiteenlopende vakken, van tramconducteur tot dienstmeisje en van lithograaf tot los werkman. ${ }^{165}$ 1

De vraag is, waarom de commissie koos voor een vorm van hulp aan oudleerlingen van het BLO waarbij het uitgangspunt was dat zij in de maatschappij konden blijven wonen. Van twee leden van de commissie, K.H. Bouman en Herderschêe, is bekend dat zij zich aangetrokken voelden tot het eugenetisch gedach- 
tegoed, dat in deze tijd ook extremer aanhangers vond. T. Bruijn, een Amsterdams schoolhoofd uit het reguliere lager onderwijs, verwoordde dat in PAIS, het blad van O\&A, in 1917:

"Als het zand der zee is hun zaad, waaruit voortkomt een heirleger van misdadigers en prostiuées. En ongeacht het moreele kwaad zijn ze een verderf voor ons ras en kosten ze aan de gemeenschap enorme kapitalen, die voor deze arme misdeelden zelf veel doelmatiger en economischer kunnen worden aangewend. ${ }^{.166}$

Het wantrouwen ten opzichte van zwakzinnigen, en daaruit voortvloeiend ten opzichte van de oud-leerlingen van het BLO, werd door de commissie in grote lijnen gedeeld, maar minder zwaar ingeschat dan Bruijn deed. $\mathrm{Zij}$ had immers uit eigen onderzoek, misschien tegen wil en dank, moeten vaststellen dat het merendeel van de oud-leerlingen van het BLO het redelijk redde in de maatschappij. Daarom wees zij segregatie van alle zwakzinnigen op grond van het enkele feit van hun zwakzinnigheid af. Commissielid Herderschêe verwoordde dat in zijn reactie op Bruijn in 1917 zó:

"Hoewel overtuigd van de zeer groote beteekenis van de erfelijkheid voor het
ontstaan der zwakzinnigheid, geloof ik niet, dat de wetenschap ons reeds thans
het recht geeft tot het aanbevelen van een dergelijke vrijheidsbeperkingen voor
alle zwakzinnigen."

De commissie geloofde vooralsnog in de kracht van de pedagogiek als belangrijk tegenwicht voor de invloed van de erfelijkheid. De pedagogiek zou in staat zijn om zwakzinnigen op het juiste pad te brengen en te houden. Op school gebeurde dat door de onderwijzers, later in de samenleving nam de ambtenaar voor de maatschappelijke zorg die rol over. Die moest volgens Herderschêe overigens niet al te goed van vertrouwen zijn ten opzichte van zijn pupillen. Het ging in de maatschappelijke zorg volgens hem vooral om 'toezicht, toezicht en nog eens toezicht!',

De keuze van de commissie voor de professionalisering van de zorg voor oudleerlingen van het BLO had in concrete zin vooral met twee zaken te maken. Als eerste met de overbelasting van de onderwijzers die deze zorg er vrijwillig bij deden. Ten tweede door de slechte ervaringen die in Den Haag waren opgedaan met patronaatszorg. Daarnaast past deze keuze in de ontwikkeling waarbij de Nederlandse hulpverlening zich in de eerste decennia van de twintigste eeuw steeds verder specialiseerde en professionaliseerde. De voorzitter van de commissie, K.H. Bouman, was in 1909 betrokken geweest bij de oprichting van het eerste consultatiebureau voor alcoholisten, waarin professionele hulpverleners, waaronder een sociaal pedagoog, samenwerkten om mensen van hun alcoholverslaving af te helpen ${ }^{169}$ In Amsterdam was men juist in deze periode begonnen met de professionalisering van de ambulante zorg voor psychiatrische patiënten. In het jaar van het verschijnen van het After-Care-Rapport, 1917, was de psychiater F.S. Meijers door de gemeentelijke gezondheidsdienst aangesteld als psychiatrisch-neurologisch adviseur. Zijn taak was het om gestichtsplaatsingen van psychisch gestoorden zoveel mogelijk te voorkomen en zo de kosten van hun verzorging voor de gemeente Amsterdam omlaag te brengen. ${ }^{170} \mathrm{Na}$ het einde van de Eerste Wereldoorlog opende 
hij een spreekuur voor zenuw- en zielszieken, eveneens onder auspciciën van de GG\&GD. ${ }^{171}$

Belangrijkste nieuwe element in het voorstel dat de commissie uitbracht was de expliciete opdracht aan de nieuw aan te stellen ambtenaar om zélf actief op zoek te gaan naar cliënten en niet te wachten totdat deze zich uit zichzelf aanmeldden. Tot dan toe waren in de ambulante hulpverlening consultatiebureaus het belangrijkste instrument geweest om mensen die hulp nodig hadden te bereiken. Kenmerk van een consultatiebureau was, dat de hulpzoekende er zelf naar toe moest komen. De ambtenaar voor de maatschappelijke zorg moest contact houden met alle kinderen die de scholen voor BLO verlieten. Zo kon hij zelf beoordelen of een oud-leerling hulp nodig had of niet. Het initiatief werd bij de hulpverlener gelegd.

Naar aanleiding van het rapport besloot het bestuur van de Vereeniging voor Spraakgebrekkige en Achterlijke Kinderen om een ambtenaar voor de maatschappelijke zorg aan te stellen. De gemeente Amsterdam kon echter, vanwege financiële problemen, hiervoor tot 1920 geen middelen aan de vereniging beschikbaar stellen. In dat jaar werd de Haarlemse BLO-onderwijzer Nagtzaam aangesteld. Hij werd echter ziek en moest zijn functie neerleggen. Er kwam een nieuwe sollicitatieprocedure, die in 1921 leidde tot de aanstelling van de Amsterdamse BLO-onderwijzer Pier de Boer. Hij begon in juni 1921 met zijn werkzaamheden.

Het Amsterdamse experiment met professionele maatschappelijke zorg werd in BLO-kringen met grote belangstelling gevolgd. A. van Voorthuijsen, de in 1921 aangestelde Inspecteur voor het BLO, schreef erover in zijn eerste verslag dat hij aan de regering over zijn activiteiten uitbracht:

"De proef, die te Amsterdam wordt genomen, lijkt mij belangrijk. Voor alle deelen van het B.O. wordt de behoefte aan een goede nazorg gevoeld. Tot nu toe heeft men langs twee wegen getracht het vraagstuk tot oplossing te brengen. Men heeft gemeend, de Nazorg geheel te kunnen overlaten aan de onderwijzers en voorts zijn er pogingen aangewend om de Nazorg op te dragen aan verschillende belangstellenden, die als patroon de belangen der kinderen moesten behartigen. Het zal thans blijken, of de zorg, die de kinderen noodig hebben, niet op de beste wijze verleend kan worden door een ambtenaar die zijn volle werkkracht aan dezen arbeid kan wijden. ${ }^{172}$

\subsection{Nazorg in Amsterdam 1921-1922}

De benoeming van Pier de Boer als ambtenaar voor de maatschappelijke zorg was niet helemaal onomstreden. Hij was overtuigd sociaal-democraat en dat riep kennelijk weerstanden op. De directeur van school 2 voor BLO haalde dit onderwerp aan in een aanbevelingsbrief die hij aan de sollicitatiecommissie zond en gaf aan, dat hij niet verwachtte dat dit problemen zou geven:

"...[er] zou twijfel kunnen bestaan wat betreft de geschiktheid van de Heer de Boer. Het is over deze kwestie, dat ik nog al eens met hem gesproken heb. Ik stelde hem o.a. de vraag, of hij als sociaal-democraat de geschikte man zou kunnen zijn, om met werkgevers te onderhandelen (...) Hij kent het achterlijke kind en beseft dus ten volle, dat hier geen sprake kan zijn van eischen stellen. Hij begrijpt, dat het vaak een gunst zal zijn, wanneer werkgevers besluiten onze kinderen in dienst te nemen. In de zeer vele gevallen, dat hij ontslagen leerlingen 
hielp plaatsen, is mij dan ook steeds gebleken, dat deze zorg hem met grote gerustheid kon worden worden toevertrouwd. ${ }^{.173}$

De opvattingen van De Boer over zwakzinnigheid weken niet wezenlijk af van de meningen die hierover algemeen in het BLO voorkwamen. Ook hij werd heen en weer geslingerd tussen de angst voor de slechte aanleg van zwakzinnigen en het geloof in de kracht van de pedagogiek. Net zoals de After-Care-commissie vond hij daarom dat een voortdurend toezicht op zwakzinnigen noodzakelijk was, zodat er snel ingegrepen kon worden als het mis mocht gaan.

"leder onzer kan vaak met zekerheid zeggen, dat voor tal van onevenwichtige en degeneratieve naturen deze steun (van de onderwijzers in het BLO, LB) onvoldoende zou zijn; dat deze zwakzinnigen op een leeftijd en in omstandigheden dat ze hulp en leiding het slechtst konden ontberen, zouden vallen en moreel zouden verongelukken; dat ze door hun gebrekkigen aanleg en hun anti-sociale eigenschappen zonder voortdurende steun niet zouden kunnen slagen. ${ }^{174}$

De Boer maakte direct een vliegende start. Hij begon in juni 1921 met zijn werk en kreeg dat jaar nog de verantwoordelijkheid over 220 pupillen. Slechts een kleine minderheid, 32 in totaal, bestond uit kinderen die in die periode de scholen voor $\mathrm{BLO}$ hadden verlaten. ${ }^{175}$ Alle anderen hadden het BLO in eerdere jaren verlaten. Zijzelf of mensen in hun directe omgeving hadden de hulp van de ambtenaar voor de maatschappelijke zorg ingeroepen. De redenen daarvoor liepen uiteen:

"... misdragingen thuis, aanraking met politie of justitie, werkloosheid, dreigend ontslag, verzoek om hulp voor plaatsing, sociale onbruikbaarheid, gestichtsverzorging enz..."176

De Boer maakte het zichzelf bij de uitvoering van zijn werk zeker niet gemakkelijk. Hij stelde dat de ambtenaar voor de maatschappelijke zorg de contacten met zijn pupillen alléén diende te onderhouden. Alleen voor de administratie zou een hulpkracht kunnen worden aangesteld. Hij meende dat de ambtenaar voor de maatschappelijke zorg hierdoor het grootst mogelijke overwicht over zijn pupillen zou kunnen verkrijgen.

De Boer volgde de aanwijzingen in het After-Care-rapport over inrichting van zijn werk op. Hij hield in de avonduren op verschillende scholen voor BLO spreekuur. Hij overlegde met onderwijzers over de leerlingen die de school gingen verlaten en als het eenmaal zover was, zocht hij werk voor hen.

In het eerste halfjaar van zijn werkzaamheden ontwikkelde hij een begin van methodiek om zijn pupillen te begeleiden. Die hield in, dat hij na plaatsing in werk regelmatig op bezoek ging bij de pupil, diens ouders en de werkgever, om te voorkomen dat de pupil voortijdig ontslagen zou worden. Hij achtte dit regelmatige toezicht in de eerste twee jaar na plaatsing bij een werkgever noodzakelijk. Daarna maakte hij een schifting tussen diegenen die nog maar weinig hulp nodig hadden en diegenen voor wie intensieve begeleiding nodig bleef. $^{178}$

Het zoeken naar arbeidsplaatsen ging De Boer goed af. In 1921 plaatste hij 48 pupillen in totaal 61 maal in werk. ${ }^{179}$ Net als Wepster in Dordrecht kreeg ook hij te maken met pupillen voor wie het niet mogelijk bleek om arbeid in loondienst te vinden. 
"Een belangrijke groep, die door de 'Nazorg' zal moeten worden geholpen, zijn de sociaal ongeschikten. Het zijn die zwakzinnigen, waarvan bij het van school gaan met vrij groote zekerheid kan gezegd worden, dat zij op de, in onze maatschappij daarvoor aangegeven, wijze zich nooit een plaats zullen veroveren, die hen als volwassenen in staat zal stellen, in hun eigen onderhoud te voorzien. ${ }^{180}$

Hij meende, dat als er voor deze groep niets gedaan werd, de samenleving voor grote problemen geplaatst zou worden. Uiteindelijk zou gestichtsplaatsing voor de meesten van hen onvermijdelijk worden, waardoor de gemeenschap op hoge kosten zou worden gejaagd. ${ }^{181}$ De Boer onderscheidde twee verschillende groepen binnen deze sociaal ongeschikten.

"Behalve de imbecillen, die om hun zeer gebrekkige verstandelijke ontwikkeling tot deze groep behooren, moeten ook vaak zwakzinnigen met iets hoogerstaand intellect bij de sociaal ongeschikten worden ingedeeld, of om gebrekkige lichamelijke ontwikkeling of door hopelooze onhandigheid of door karakterafwijkingen. ${ }^{182}$

Voor beide groepen vond De Boer het erg belangrijk dat zij de gelegenheid kregen om arbeid te verrichten. De therapeutische waarde hiervan was in zijn ogen zó groot, dat het de gestichtsplaatsing van veel sociaal ongeschikte oud-leerlingen van het BLO erdoor zou kunnen worden voorkomen.

"In zeer vele gevallen zou de aanleiding tot gestichtsverzorging vervallen, indien aan deze zwakzinnigen werk kon worden verschaft, waarbij zij productief waren. De regelmatige arbeid waarop dan de zwakzinnige zijn gedachten zou concentreeren, zal, naast eenig geldelijk voordeel, ook een zeer weldadigen invloed uitoefenen op het karakter en den omgang met deze misdeelden minder moeilijk maken. ${ }^{183}$

Daarom pleitte hij al vroeg voor de oprichting van een werkinrichting voor zwakzinnigen in Amsterdam, zoals die al in Dordrecht bestond.

In het jaar 1922, het eerste volledige jaar dat De Boer als ambtenaar voor de maatschappelijke zorg actief was, werkte hij zijn methodiek verder uit. Hij ontwikkelde speciale formulieren om de informatievoorziening over zijn pupillen te standaardiseren. De onderwijzers van het BLO én de schoolarts moesten deze invullen op het moment dat een leerling de school verliet. De Boer vulde de informatie verder aan, waarbij naast de schoolse prestaties van de oud-leerlingen ook zaken als hun sociale omgeving, karakter, handigheid en dergelijke aan de orde kwamen. ${ }^{184}$

Aan de hand van deze gegevens bepaalde De Boer welke hulp hij voor de betrokken oud-leerling noodzakelijk achtte. Daarvoor hanteerde hij de term "bruikbaarheid', in de zin van geschiktheid voor arbeid in loondienst. Voor de mate van bruikbaarheid waren volgens hem ook invloeden van buitenaf op de leerling van belang. Daarbij ging het om zaken die De Boer omschreef als 'slecht milieu, slechte gewoonten, onbetrouwbaarheid - oneerlijkheid enz. ${ }^{185}$ Deze beoordeling leidde tot een indeling van oud-leerlingen naar hun mate van arbeidsgeschiktheid. Over het jaar 1922 zag deze beoordeling er zó uit (zie tabel 2): 
Tabel 2

Mate van geschiktheid voor de arbeidsmarkt van nazorgpupillen Amsterdam $1922^{186}$

Aantal $(\mathrm{N}=72)$

Geschikt

43

Twijfelachtig

21

Ongeschikt

8

Voor degenen die geschikt voor arbeid zouden kunnen zijn (de categorieën 'geschikt' en 'twijfelachtig'), bestond de volgende begeleidingsfase uit het zoeken van een arbeidsplaats. De Boer wist hiervoor in korte tijd een netwerk op te bouwen van werkgevers, vooral in het kleinbedrijf, die bereid waren om oud-leerlingen van het BLO in dienst te nemen. Voor vrijwel alle kinderen die in bovengenoemde categorieën vielen, 62 in totaal, lukte dat, terwijl juist in deze periode Nederland werd getroffen door een korte maar hevige economische crisis. ${ }^{187} \mathrm{Zij}$ werden, zoals tabel 3 laat zien, in verschillende vormen van bedrijvigheid geplaatst.

\section{Tabel 3}

Plaatsing van nazorgpupillen in het bedrijfsleven, nazorg Amsterdam $1922^{188}$

\begin{tabular}{ll}
\hline & aantal $(\mathrm{N}=62)$ \\
Ambachtelijk bedrijf & 37 \\
Fabrieksarbeid & 14 \\
Thuis & 5 \\
Ongeschikt & 6 \\
\hline
\end{tabular}

Over de twee eerste jaren van zijn werkzaamheden schreef De Boer uitgebreide verslagen. Ze waren bedoeld om het bestaansrecht van zijn werk aan te tonen. Daarin slaagde hij. Hij liet zien dat er onder oud-leerlingen van het BLO grote behoefte bestond aan ondersteuning, niet alleen bij het zoeken naar een eerste baan, maar ook in de periode die daarop volgde. Hij toonde aan dat het goed mogelijk was om oud-leerlingen daarin te ondersteunen maar gaf ook aan waarin zijn hulp tekortschoot. Dat laatste betrof vooral de oud-leerlingen die niet tot arbeid in loondienst in staat waren. Voor deze groep wenste hij de oprichting van een werkinrichting.

De verslagen maakten in elk geval indruk op de inspecteur van het BLO, A. van Voorthuijsen. In 1923, toen het Amsterdamse BLO door de Vereeniging voor Spraakgebrekkige en Achterlijke Kinderen aan de gemeente werd overgedragen, stelde hij het werk van De Boer ten voorbeeld aan het BLO in het hele land.

"Als later mogelijk het Rijk de nazorg nog eens zal regelen, dan zal stellig daarbij het voorbeeld van Amsterdam gevolgd worden." ${ }^{189}$

\subsection{De nazorg als onderdeel van de geestelijke gezondheidszorg}

De positie van de ambtenaar voor de maatschappelijke zorg was na de eerste twee jaar van zijn werkzaamheden nog allerminst zeker. Bij de overdracht van de scholen voor BLO aan de gemeente Amsterdam was De Boer bij de Vereniging voor Spraakgebrekkige en Achterlijke Kinderen achtergebleven. Binnen de gemeentelij- 
ke organisatie bestond namelijk onenigheid over de vraag waar de nazorg zou moeten worden ondergebracht. Dat had te maken met een conflict tussen twee rivaliserende gemeentelijke diensten, die elk hun werkveld zoveel mogelijk probeerden uit te breiden: het Bureau voor Beroepskeuze dat onder leiding stond van de oudonderwijzer E.J. van Det ${ }^{190}$ en de in 1923 ontstane Gemeentelijke Geneeskundige en Gezondheidsdienst (GG\&GD), de samenvoeging van de Geneeskundige-en de Gezondheidsdienst, onder leiding van de energieke bedrijfsarts Louis Heijermans. ${ }^{191}$ Beide diensten aasden op de nazorg, die zij allebei als natuurlijk onderdeel van hun werk zagen. Van Det als onderdeel van de beroepskeuze, die volgens hem voor zwakzinnigen niet wezenlijk afweek van de normalen, Heijermans als onderdeel van de zorg voor geestelijk abnormalen, zoals deze door Meijers in zijn spreekuur voor zenuw- en zielszieken werd uitgevoerd.

Herderschêe, als schoolarts bij het BLO en medeauteur van het After-CareRapport op gemeentelijk niveau niet zonder invloed, pleitte voor onderbrenging bij de GG\&GD. Hij schreef hierover in 1923 een amicebriefje aan Heijermans:

"Nu bestaat het gevaar, dat bij de overname (...) deze zonder meer die after-care onderbrengen bij de afdeeling voor de beroepskeus. En dat is volkomen fout (...) Mij dunkt èn medische dienst aan de scholen èn aftercare behooren bij den geneeskundigen dienst en liefst bij de onderafdeeling van Meyers, want ook in mijn werk heb ik veel meer contact noodig met dien dienst, waaronder toch al onze pupillen behooren..."

Heijermans wist het pleit uiteindelijk in het voordeel van de GG\&GD te beslechten. Op 18 december 1923 werd De Boer bij deze dienst aangesteld, als onderdeel van de psychiatrische dienst van F.S. Meijers. Belangrijke overweging voor deze keuze waren de grote overeenkomsten die er tussen beide werkvormen bestonden. Allebei waren ze er in eerste instantie op gericht om gestichtsverpleging van hun cliënten te voorkomen. En men veronderstelde een grote overeenkomst tussen beide doelgroepen, zwakzinnigen en krankzinnigen. Ze behoorden beiden tot de geestelijk abnormalen en werden allebei gezien als een risico voor de maatschappij, dat zoveel mogelijk beperkt diende te worden. Zwakzinnigen werden nadrukkelijk, zoals Herderschêe zo duidelijk verwoordde, tot het werkveld van de psychiatrie gerekend.

In het jaar 1923, toen nog niet duidelijk was bij welke dienst de nazorg zou worden ondergebracht, schreef De Boer een rapport aan de gemeentē Amsterdam over de taken van zijn werk en de manier waarop deze ingevuld moesten worden. Hierin omschreef hij de belangrijkste taak van de nazorg als de

\section{"geestelijke, moreele en sociale verzorging van de van de scholen ontslagen zwakzinnigen,"193}

Bij de invulling van deze taak, die hierboven al is behandeld, stelde De Boer 'controle en leiding, ${ }^{194}$ centraal in de manier waarop hij met pupillen én hun ouders wenste om te gaan. Nieuw in dit rapport was het voorstel om in Amsterdam een vorm van avondverzorging voor oud-leerlingen van het $\mathrm{BLO}$ in te voeren. Hierdoor zou de controle en leiding van nazorgpupillen tot de avonduren kunnen worden uitgebreid. De Boer vond een nuttige avondbesteding erg belangrijk, om te voor- 
komen dat zijn pupillen op het slechte pad zouden raken, terwijl hij tegelijkertijd moest constateren dat het voor zwakzinnigen erg moeilijk was om aansluiting te vinden bij reguliere jeugd- en jongerenverenigingen. ${ }^{195}$

\subsection{De Arbeidsschool voor Geestelijk Zwakken}

Tijdens dezelfde overgangsperiode in 1923 schreef De Boer ook een rapport voor de gemeente waarin hij zijn eerdere pleidooi voor een werkinrichting voor oudleerlingen van het BLO verder uiteenzette. Onder zijn pupillen waren er in dat jaar 23 die voor plaatsing op een dergelijke inrichting in aanmerking zouden kwamen

"De meeste dezer kinderen zijn den geheelen dag thuis, komen alleen op straat onder toezicht, zoodat de ouders den geheelen dag met de onmiddellijke zorg zijn belast; anderen brengen een belangrijk deel van hun tijd door op straat zonder toezicht, waardoor ze een straattype worden." ${ }^{196}$

Een aantal van deze kinderen had een eenvoudig baantje, maar verdiende te weinig om er in eigen onderhoud van te kunnen voorzien. De ouders vonden dat meestal van ondergeschikt belang.

"Gewaardeerd wordt hierbij niet zoozeer 'hij verdient' als wel het feit dat de kinderen voor korter of langer tijd buitenshuis ergens onder dak zijn." ${ }^{197}$

Zolang deze kinderen nog thuis konden wonen, was het probleem beperkt van aard. Maar als later de ouders de verzorging niet meer aan zouden kunnen of zouden overlijden, zou voor deze groep gestichtsverpleging onvermijdelijk worden. Een werkinrichting zou dat kunnen voorkomen. ${ }^{198}$ Het was in de optiek van De Boer een tweesnijdend zwaard. De gemeente kon bezuinigen op de kosten van gestichtsverpleging en de betrokkenen hoefden niet, vaak tegen hun zin, uit hun eigen sociale omgeving gehaald te worden. De Boer stelde daarom voor om een dergelijke inrichting op te zetten, in eerste instantie voor twaalf jongens. Die zouden werken onder de directe leiding van een werkmeester. De Boer wilde zelf de algehele leiding op zich nemen. ${ }^{199}$ Samen met Herderschêe had De Boer zich al georiënteerd op de manier waarop een dergelijke werkinrichting kon worden opgezet. Ze hadden een Haarlemse werkinrichting voor zwakzinnigen, die in 1922 enkele maanden actief was geweest, bezocht. ${ }^{200} \mathrm{Ze}$ hadden er gezien dat het vlechten van kokosmatten, het fabriceren van borstels en het matten van stoelen geschikte arbeid vormden voor mannelijke oud-leerlingen van het BLO. ${ }^{201}$

Voor meisjes vond De Boer een werkinrichting voorlopig niet nodig. Hij veronderstelde dat de meesten van hen thuis in de huishouding konden worden ingezet. Bovendien gaf hij aan er geen idee van te hebben, welk werk voor vrouwelijke oud-leerlingen van het BLO geschikt zou kunnen zijn. ${ }^{202}$

De gemeente Amsterdam ging niet op het voorstel van De Boer in. Er kwam geen gemeentelijke werkinrichting voor oud-leerlingen van het BLO. Daarop nam De Boer samen met F.S. Meijers het initiatief om een werkinrichting op particuliere basis op te richten. Daarbij gingen zij voortvarend te werk. De Arbeidsschool voor Geestelijk Zwakken opende op 1 juni 1924 de deuren. ${ }^{203}$ Organisatorisch was de inrichting ondergebracht bij de Wilhelmina Vereeniging, die onder controle van F.S. Meijers stond. ${ }^{204}$ Deze vereniging was in 1897 ontstaan om de opleiding van verpleegsters in de psychiatrie te verzorgen, maar werd door Meijers 
voor zijn eigen doelstellingen gebruikt. ${ }^{205}$ De werkinrichting werd ondergebracht in het hoofdkantoor van de vereniging, het Wilhelminahuis aan de Prinsengracht. Pier de Boer werd aangesteld als directeur. Voor de dagelijkse leiding werd een werkmeester aangenomen. Er konden achttien jongens terecht. ${ }^{206}$ Medio 1925, toen de Wilhelmina Vereniging financiële moeilijkheden kreeg, nam de Centrale Vereeniging ter Behartiging van de Maatschappelijke Belangen van Zemuw- en Zielszieken, waarin F.S. Meijers eveneens een centrale rol speelde, de werkinrichting over. ${ }^{207}$

Over de toelating tot de werkinrichting besliste F.S. Meijers in zijn functie van hoofd van de psychiatrische afdeling van de Amsterdamse GG\&GD. De belangrijkste doelgroep bestond uit oud-leerlingen van het BLO die niet of onvoldoende tot arbeid in loondienst in staat waren, maar er waren ook twee plaatsen gereserveerd voor psychopathen. ${ }^{208}$ Dat bleek geen gelukkige keuze, omdat de laatsten voor veel onrust onder de andere tewerkgestelden veroorzaakten. In 1926 was men met deze combinatie alweer gestopt. ${ }^{209}$

De werkinrichting had de beschikking over 2 lokalen. Er werden borstels, kokosmatten en pantoffels gemaakt. De inrichting werd nadrukkelijk gezien als orgaan van de nazorg:

"Het nut van de arbeidsschool is in hoofdzaak daarin gelegen, dat zij maatschappelijke geschiktheid tracht te kweken bij die zwakzinnigen, welke anders in inrichtingen zouden moeten verpleegd worden. ${ }^{210}$

De kosten bedroegen per pupil per jaar fl. 250,- ( $€ 113,-)$. In principe moesten de ouders van de betrokken pupillen dat bedrag zelf betalen. ${ }^{211}$ Veel mensen konden dat niet, daarom vroeg De Boer bij de directeur van de Geneeskundige Dienst, Heijermans, een subsidie van fl. 200,- (€91,-) per pupil per jaar aan. ${ }^{212}$ Heijermans adviseerde de betrokken wethouder deze subsidie te verlenen. ${ }^{213}$ Het college van Burgemeester en Wethouders nam het advies over, met dien verstande dat er een bovengrens in de subsidiëring werd gesteld van fl. $2400,-(€ 1091,-)$ per jaar. ${ }^{214}$ Amper een half jaar later, in juli 1925, bleek dat voor veel ouders ook de eigen bijdrage van fl. 50,- ( $€ 23,-)$ niet konden betalen. Daarom besloot de gemeente de subsidie op te trekken tot fl. $250,-(€ 113,-)$ per pupil per jaar. ${ }^{215}$

De Arbeidsschool voor Geestelijk Zwakken richtte zich in de eerste jaren van haar bestaan vooral op debiele oud-leerlingen van het BLO met gedrags- en karaktermoeilijkheden, die daardoor niet of zeer moeilijk in het bedrijfsleven terechtkonden. Over wat er met de imbecille oud-leerlingen moest gebeuren bestonden grote meningsverschillen tussen de betrokkenen bij het Amsterdamse BLO en de medici van de geneeskundige dienst.

Imbecillen volgden in Amsterdam onderwijs in aparte klassen van het $\mathrm{BLO}$, de zogenaamde bezinkingsklassen. ${ }^{216}$ De lessen die ze er kregen waren eenvoudiger dan in het BLO voor debielen. Ze bleven vaak langer op school dan op grond van de leerplichtwet noodzakelijk was, omdat er voor hen na het verlaten van de school geen dagbesteding beschikbaar was. Om hierin verandering te brengen, stelden in 1925 enkele schoolhoofden uit het BLO aan de gemeente Amsterdam voor, om voor deze groep een aparte werkinrichting te beginnen. Deze zou aan de scholen voor BLO verbonden zijn. Zo zouden de tewerkgestelden onder pedagogisch toezicht kunnen blijven staan. 
Van medische zijde werd er bij de geneeskundige dienst tegen een dergelijke opzet ernstig bezwaar gemaakt. De directeur van de dienst, Heijermans, organiseerde er een conferentie over, waarbij hij alle betrokkenen bij deze problematiek bijeenbracht: de hoofden van de scholen voor BLO, Pier de Boer, F.S. Meijers en D. Herderschêe. De medici, Meijers en Herderschêe, stelden dat de imbecillen op de arbeidsschool voor geestelijk zwakken geplaatst moesten worden. Deze zou voor dat doel moeten worden uitgebreid. Ze vonden dat de band tussen imbecil en school moest worden doorgesneden.

"Wij bemoeien ons (...) met de opvoeding van de geestelijk minderwaardigen en indien deze kinderen volwassen menschen worden, kunnen zij ze op de school toch niet houden. Wij missen echter de moed om deze ouderen reeds in de Maatschappij te plaatsen en daarom juist is er behoefte aan een werkinrichting. een soort overgang tusschen school en de maatschappij.".217

De Boer koos in dit conflict de kant van het BLO. Hij vond dat imbecillen zo lang mogelijk onder pedagogisch toezicht moesten blijven, om te voorkomen dat ze naar een gesticht zouden moeten worden overgebracht.

"De heer De BOER zegt, dat er op het oogenblik nog te veel kinderen naar buiten gaan (d.w.z. naar gestichten en pleeggezinnen buiten de stad, LB) en het streven moet zijn om ze in Amsterdam te houden, zoodat de Gemeente zelf de beschikking over haar materiaal houdt." 218

Het was uiteindelijk Heijermans die de knoop doorhakte. Hij vond het ongewenst, dat het BLO invloed zou krijgen op de zorg voor haar oud-leerlingen. Die zorg was opgedragen aan de GG\&GD en dat moest zo blijven. Net als Herderschêe en Meijers vond hij dat imbecille kinderen door het BLO losgelaten moesten worden. Het beste moment daarvoor, stelde hij, lag bij het bereiken van de leerplichtige leeftijd. ${ }^{219}$ Daarom adviseerde hij aan het College van Burgemeester en Wethouders om met de Wilhelminavereniging te gaan onderhandelen over de plaatsing van oud-leerlingen van de bezinkingsklassen op de werkinrichting. ${ }^{220}$ Dat zou uiteindelijk in 1927 gebeuren, toen de werkinrichting de beschikking kreeg over een groter gebouw en kon uitbreiden. 



\section{Hoofdstuk 4 \\ Programma voor de nazorg Haarlem 1922-1925}

"De tijd dat de zwakzinnige voorbeschikt was tot de maatschappelijke ondergang, tot prostitutie, alcoholisme, vagebondage en gevangenis is voorbij."

Haarlems nazorgrapport, $1924^{221}$

In dit hoofdstuk behandel ik het ontstaan van de nazorg in Haarlem. Hier werd, net als in Amsterdam, voor professionalisering van de zorg voor oud-leerlingen van het BLO gekozen. De aanleiding hiervoor was een rapport dat het belang van de Haarlemse omstandigheden verre oversteeg en bepalend werd voor de invulling van de nazorg in heel Nederland.

In de eerste paragraaf ga ik in op de voorgeschiedenis van de Haarlemse nazorg, die aanleiding gaf tot het schrijven van het nazorgrapport. De tweede paragraaf is geheel gewijd aan dat rapport en de reacties die het opriep. Ik sluit dit hoofdstuk af met de wijze waarop de Haarlemse nazorg in de praktijk werd vormgegeven.

In dit hoofdstuk ligt de nadruk vooral op de onderzoeksvragen die met de inhoud van het nazorgwerk te maken hebben. Ik ga in op de vraag, wat de doelgroep van de nazorg was, welke werkwijzen de nazorg hanteerde en, in wat mindere mate, hoe er binnen de nazorg over zwakzinnigheid werd gedacht.

\subsection{Valse start}

In Haarlem stelde de plaatselijke afdeling van de Vereniging van Onderwijzers en Artsen (O\&A) in de zomer van 1922 aan het gemeentebestuur voor om, naar Amsterdams voorbeeld, een ambtenaar voor de nazorg aan te stellen. ${ }^{222}$ Vooral het hoofd van de openbare school voor BLO, S. Hiemstra, was een groot voorstander van een goed georganiseerde hulp voor zijn oud-leerlingen. Daarbij moesten volgens hem de volgende aspecten aan bod komen:

\footnotetext{
"ten eerste de z.z. aan het werk houden;

ten tweede aparte zorg voor z.z. die biezondere leiding vereischen, en die stammen uit slechte omgeving, in aanraking komen met de rechterlijke macht: plaatsing in gezinnen, patronaatswezen etc.;

ten derde het formeeren van een inrichting voor productieven arbeid, welke inrichting tevens een toevlucht zij voor werklooze z.z., voor hen, die vaak van patroon wisselen en licht arbeidsschuw worden. Natuurlijk gaat hieraan vooraf, het opsporen van arbeidsmogelijkheden. ${ }^{\text {223 }}$
}

Het Haarlemse gemeentebestuur wees in eerste instantie het verzoek van O\&A af. Het stelde zich op het standpunt dat er in de stad al voldoende aan nazorg voor oud-leerlingen van het BLO werd gedaan, waarbij het in het bijzonder wees op het herhalingsonderwijs dat aan deze groep werd gegeven. ${ }^{224}$

\footnotetext{
" Zij (het college van B\&W, LB) hebben voor achterlijke kinderen een ruime gelegenheid opengesteld om herhalingsonderwijs te ontvangen en bieden meer aan
} 
dan eenige wet of besluit van hen eischt. Behalve dat wordt de vereeniging 'Volksonderwijs' gesubsidieerd met f. 700 ( $€ 318,-$, LB) voor het houden van ontspanningsavonden, die dan ook als nazorg mogen worden beschouwd. Een particuliere vereeniging geeft gelegenheid eenige eenvoudige vakken te leeren en de onderwijzers zorgen zooveel als in hun vermogen is om hun leerlingen geplaatst te krijgen." 225

In dezelfde periode was de Spaarnestichting, de Haarlemse afdeling van de Vereniging Maatschappelijk Werk bij Zenuwlijden en Krankzinnigheid, die in 1917 ook al betrokken was geweest bij het ontstaan van de Dordtse werkinrichting (zie paragraaf 2.4.5), bezig met het opzetten van een Arbeidsschool voor zwakzinnigen. De stichting kreeg daarvoor van de gemeente Haarlem een subsidie voor het jaar 1922. In september van dat jaar opende deze arbeidsschool de deuren. In 1924 keek J.H. Schuurmans Stekhoven, de voorzitter van de landelijke vereniging, hierop terug:

"Twee jaar geleden heeft de Spaarne-stichting te Haarlem (een spruit van de vereeniging Maatschappelijk Werk bij zenuwlijden en krankzinnigheid) zich verdienstelijk gemaakt door in het Proveniershuis voor oud-leerlingen van het buitengewoon onderwijs een werkgelegenheid (of arbeidsschool) te openen, waar deze leerlingen boender- en borstelmaken, mattenvlechten en ook stoelenmatten zouden kunnen leeren. De kosten waren tot einde 1922 gedekt, maar ook voor het jaar 1923 meende men op hulp van de gemeente te mogen rekenen"226

Schuurmans Stekhoven verbaasde zich over het verzoek van O\&A om een ambtenaar voor de nazorg in Haarlem aan te stellen. Hij beschouwde dat als een vorm van concurrentie voor de werkinrichting. ${ }^{227}$

De gemeenteraad van Haarlem was het niet eens met de beslissing van het college van burgemeester en wethouders om geen nazorgambtenaar aan te stellen. Men wilde op z'n minst dat het nazorgvraagstuk nader werd onderzocht. In de zomer van 1922 nam de raad een motie aan, waarin werd voorgesteld om

"... eene Commissie in te stellen, teneinde te onderzoeken, wat te Haarlem kan geschieden voor de nazorg van de oud-leerlingen der Buitengewone School voor Lager Onderwijs." 228

Deze commissie, onder voorzitterschap van de Amsterdamse nazorgambtenaar Pier de Boer, die lang in het Haarlemse BLO had gewerkt, werd op 1 januari 1923 geïnstalleerd en zou in de loop van 1924 verslag uitbrengen. ${ }^{229}$

Niet iedereen in het BLO was overtuigd van het belang van de aanstelling van een nazorgambtenaar. C. Visser, onderwijzer aan het openbare Haarlemse BLO, schreef er in de zomer van 1922 een artikel over in de Haarlemsche Courant, onder de titel Een Ambtenaar Onnoodig. Hierin stelde hij dat een werkinrichting, naast het avondonderwijs, voldoende was om de oud-leerlingen van het BLO te ondersteunen. Zijn stelling was, dat vooral de imbecillen veel aandacht nodig hadden en dat daar met een werkinrichting voldoende in werd voorzien. ${ }^{230} \mathrm{Hij}$ vreesde dat een ambtenaar niet genoeg te doen zou hebben in een middelgrote stad als Haarlem. ${ }^{231}$ Volgens hem waren de onderwijzers van het BLO het meeste geschikt om het nazorgwerk te doen, omdat zij elke oud-pupil van hen goed kenden en dus wisten hoe ermee om te gaan. 
"leder zwakzinnig kind is een individu op zichzelf, dat men in zijn goede en slechte kwaliteiten, in zijn bijzondere neigingen en begeerten, in zijn bekwaamheden en gebreken, slechts na langdurigen dagelijkschen omgang leert kennen en begrijpen. Daarom is de beste nazorger voor een oud-leerling de onderwijzer, die hem een aantal jaren in zijn klasse had." ${ }^{232}$

Voor de werkinrichting van de Spaarnestichting kreeg het aannemen van deze motie een dramatisch vervolg. De gemeente Haarlem besloot, om lopende het onderzoek naar de nazorg alle subsidies voor bestaande vormen van nazorg stop te zetten. Voor 1923 kreeg de Spaarnestichting geen geld meer en werd daardoor gedwongen de werkinrichting, vijf maanden na de opening, alweer te sluiten.

\subsection{Het Haarlemse nazorgrapport}

De Comissie-De Boer, die officieel de Commissie voor de Nazorg bij het Buitengewoon Onderwijs te Haarlem heette, bestond uit leden van de Haarlemse afdelingen van alle onderwijzersorganisaties (algemeen-liberaal, socialistisch, christelijk en rooms-katholiek) en van O\&A. De commissie formuleerde als uitwerking van de opdracht die ze van de gemeenteraad had gekregen, om te onderzoeken wat er in Haarlem kon gebeuren voor de nazorg van de oud-leerlingen van het BLO, een drietal onderzoeksvragen:

"1ste.

$\mathrm{Na}$ te gaan of Zwakzinnige Oud-leerlingen hulp en verzorging noodig hebben.

2 de.

3 de. Of die hulp en verzorging hun wordt gegeven. Zoo niet, hoe daarin voorzien moet worden.".233

Aan de hand van deze drie vragen zal ik de inhoud van het rapport verder behandelen.

\subsubsection{Behoefte aan hulp en verzorging}

Om de eerste onderzoeksvraag te kunnen beantwoorden stelde de commissie een onderzoek in naar de levensomstandigheden van alle oud-leerlingen van het Haarlemse BLO. Dat waren er in totaal 235. Van hen konden er 174 teruggevonden worden. Zij werden bij het onderzoek betrokken.

In het onderzoek kwamen aspecten aan de orde als de lichamelijke en psychische toestand en het milieu waarin oud-leerlingen verkeerden, om in te kunnen gaan op de kwaliteit van hun levensomstandigheden. Verder wilde de commissie weten, hoe hun loopbaan in het bedrijfsleven was geweest en in welke mate ze arbeidsgeschikt waren. Dit om te kunnen nagaan in hoeverre er onder oudleerlingen van het BLO behoefte aan hulp bestond. Ook wilde de commissie weten waar de oorzaken van de hulpbehoefte te zoeken waren: op lichamelijk, geestelijk of maatschappelijk gebied. ${ }^{234}$

De informatie over de oud-leerlingen werd verzameld door middel van vragenlijsten. Er werden verschillende uitvoeringen van gemaakt, voor BLOscholen, ouders en werkgevers van de oud-leerlingen. Aan de scholen werden algemene gegevens gevraagd als duur van het schoolbezoek, mate van schoolverzuim en dergelijke, maar er werd ook geïnformeerd naar het karakter van betrokken oud-leerling. ${ }^{235}$ De vragenlijst voor de ouders bevatte vragen over de werkgever, het gedrag thuis en buitenshuis, de verhouding met het andere geslacht, contacten 
met justitie en politie, eventuele gestichtsopname, prostitutie, drankmisbruik en of men ooit de hulp van de school had ingeroepen. Tevens werd het huiselijk milieu beoordeeld door degene die de vragenlijst had afgenomen. ${ }^{236}$ De laatste vragenlijst was voor werkgevers bestemd en bevatte vragen over de lichamelijke kracht van de oud-leerling, de werklust, aandacht, orde en regel, vorderingen in het werk, de verhouding tot de collega's en tot de leidinggevenden. ${ }^{237}$

Naar aanleiding van deze gegevens stelde de commissie van elke oudleerling afzonderlijk vast of diens toestand al dan niet als bevredigend kon worden aangemerkt. De commissie

"... had daarbij uitsluitend het oog op de materieele, geestelijke en moreele verzorging op het oogenblik van onderzoek. De feitelijke toestand dus wat de algeheele verzorging betrof, zonder de physische of psychische toestand van individu-zelf als uitgangspunt te nemen."${ }^{.23}$

Daarbij speelden gezinsomstandigheden, als 'armoede, drankzucht, ontucht of andere slechte milieuomstandigheden ${ }^{239}$ een rol, maar ook

"...de onmogelijkheid om remmend op verkeerde eigenschappen van de(n) betrokken zwakzinnige te werken of hem op te heffen uit zijn toestand van lichamelijke of geestelijke achteruitgang...240

De commissie kwam tot de conclusie, dat de toestand van 80 van de 174 oudleerlingen als bevredigend kon worden beschouwd.

"De huiselijke verzorging dezer zwakzinnigen liet nl op dit oogenblik niet of weinig te wenschen over. Ze waren geplaatst in een milieu, dat voor hen zonder gevaar geacht moet worden: voeding en kleeding waren voldoende. ${ }^{\text {241 }}$

Over dertien oud-leerlingen werd geen oordeel gegeven, van 61 oud-leerlingen werd vastgesteld dat hun toestand onbevredigend was.

\subsubsection{Noodzaak van hulp}

Vervolgens stapte de commissie over op de vraag of er onder oud-leerlingen behoefte aan hulp bestond, nu of in de toekomst, en of deze hulp noodzakelijk was of gewenst. ${ }^{242} \mathrm{Om}$ op deze vraag een antwoord te kunnen geven onderzocht de commissie allereerst of oud-leerlingen al dan niet in staat waren om arbeid in loondienst te verrichten. Dat leidde tot de volgende cijfers (zie tabel 4):

\section{Tabel 4}

Arbeidsgeschiktheid van 154 oud-leerlingen te Haarlem $1923^{243}$

\begin{tabular}{lll}
\hline & Meisjes & Jongens \\
& $\mathrm{N}=\mathbf{5 0}$ & $\mathrm{N}=104$ \\
geschikt voor loondienst & 32 & 89 \\
ongeschikt voor loondienst & 18 & 15 \\
\hline
\end{tabular}

Van de 121 oud-leerlingen die geschikt werden geacht voor werk onderzocht de commissie wat zij in werkelijkheid deden (zie tabel 5).

Voor de oud-leerlingen die in loondienst werkten, bekeek de commissie en daarin ging zij verder dan in eerdere onderzoeken was gebeurd - de hoogte van 
het loon dat werd verdiend. Aan de hand daarvan probeerde de commissie te bepalen of een oud-leerling in staat was om in het eigen onderhoud te voorzien. Daarbij hanteerde de commissie een ondergrens van fl. $15,-(€ 6,80)$ per week. Dat was gebaseerd op de gedachte, dat voor kost en inwoning 10 gulden $(€ 4,54)$ volstond en dat voor kleding en andere zaken 5 gulden $(€ 2,30)$ per week extra nodig was. ${ }^{244}$ Géén van de meisjes haalde deze ondergrens, zij verdienden tussen fl.1,75 $(€ 0,80)$ en fl.10,- $(€ 4,54)$ per week. ${ }^{245}$ Voor de jongens lag de situatie iets gunstiger, zoals de cijfers van 59 van de 67 werkende jongens aangeven in tabel 6.

\section{Tabel 5}

Werkzaamheden van 121 oud-leerlingen van het BLO te Haarlem $1923^{246}$

\begin{tabular}{lll}
\hline & Meisjes & Jongens \\
& $\mathbf{N}=\mathbf{3 2}$ & $\mathbf{N}=\mathbf{8 9}$ \\
In loondienst & 19 & 67 \\
Werkloos & 5 & 14 \\
Thuis & 6 & 3 \\
Gehuwd & 2 & 5 \\
\hline
\end{tabular}

\section{Tabel 6}

Loonniveau werkende jongens oud-leerlingen Haarlem 1922-1923 ${ }^{247}$

\begin{tabular}{ll}
\hline Hoogte van het weekloon & aantal $(\mathrm{N}=59)$ \\
Tot fl. 5,- $(€ 2,30)$ & 13 \\
Fl. 5,01 - fl. 10,- $(€ 4,54)$ & 20 \\
Fl. 10,01 - fl. 15,- $(€ 6,82)$ & 10 \\
Fl. 15,01 - fl. 20,- $(€ 9,09)$ & 8 \\
Fl. 20,01 - fl. 25,- $(€ 11,36)$ & 5 \\
Meer dan fl. 25,- $(€ 11,36)$ & 3 \\
\hline
\end{tabular}

Slechts 16 jongens verdienden meer dan het minimumbedrag van fl. $15,-(€ 6,80)$ dat de commissie had vastgesteld en van hen verdiende de helft een loon dat op of boven het toen geldende normale niveau lag. De minimumweeklonen voor ongeschoolde arbeiders in de metaal- en houtindustrie bedroegen in 1922-1923 bij een werkweek van 45 uur iets meer dan fl.25,- $(€ 11,36){ }^{248}$

Met dit deel van haar onderzoek toonde de commissie aan, dat het niet genoeg was om alleen de vraag of oud-leerlingen al dan niet loondienst verrichtten in ogenschouw te nemen om te kunnen beoordelen of zij al dan niet hulp nodig hadden. Ook de hoogte van het loon was belangrijk, vooral om vast te kunnen stellen of oud-leerlingen, die nog bij hun ouders woonden, zich in de toekomst zelfstandig staande zouden kunnen houden.

Dit alles vond de commissie nog niet voldoende om gefundeerd vast te kunnen stellen of oud-leerlingen hulp nodig zouden hebben, nu of in de toekomst. $\mathrm{Zij}$ onderzocht daarom ook op welke wijze oud-leerlingen bij hun werkgever functioneerden. 
"Behalve de loongegevens waren ook van belang (...) de mededeelingen van de werkgevers over de in hun dienst staande zwakzinnigen. Meermalen bleek hoe de factor "medelijden" bij het in dienst houden een belangrijke rol speelt en vaak de doorslag gaf in de plaats van de bruikbaarheid, waardoor naturlijk de bestaansonzekerheid veel groter is." 249

Met behulp van de gegevens over arbeidsgeschiktheid, loonniveau en functioneren bij de werkgever samen stelde de commissie een overzicht samen van de (mogelijke) noodzaak van hulp aan oud-leerlingen van het BLO in Haarlem. Daarbij werden de gegevens van 142 oud-leerlingen betrokken, zoals is te zien in tabel 7.

\section{Tabel 7}

Noodzaak van hulp aan oud-leerlingen te Haarlem $1923^{250}$

\begin{tabular}{llll}
\hline $\mathbf{N}=142$ & hulp noodzakelijk & hulp gewenst & hulp onnodig \\
Hulp nu nodig & 54 & 26 & 31 \\
Hulp in de & 17 & 14 & 0 \\
toekomst nodig & & & \\
\hline
\end{tabular}

De commissie vond hulp direct noodzakelijk voor alle imbecille oud-leerlingen, waarvan het verstandelijk niveau zó laag was dat zij niet in staat waren in loondienst te werken. Ook werd hulp direct noodzakelijk geacht voor die debiele oudleerlingen, die door hun gedrag en achtergrond niet in een reguliere baan geplaatst konden worden. Dezelfde overwegingen golden voor degenen, voor wie hulp gewenst werd geacht. Hun omstandigheden werden door de commissie als minder urgent beschouwd.

Oud-leerlingen, voor wie hulp in de toekomst noodzakelijk geacht werd, verkeerden volgens de commissie in redelijk beschermde omstandigheden. Hulp voor deze groep was pas noodzakelijk, als die bescherming zou wegvallen. Het ging hier onder andere om oud-leerlingen die bij hun ouders verbleven en in loondienst werkten maar niet voldoende verdienden om in eigen onderhoud te voorzien. Dezelfde overwegingen golden voor de oud-leerlingen, voor wie de commissie in de toekomst hulp gewenst achtte, met het verschil dat hun omstandigheden beter waren waardoor hulp minder hard nodig zou zijn. ${ }^{251}$

Aan de hand van deze gegevens stelde de commissie dat er in 1923 in Haarlem een potentiële klantenkring voor de nazorg bestond yan in totaal 112 oudleerlingen van de school voor BLO, waarvan er 80 direct hulp nodig hadden en er voor 32 hulp op termijn werd voorzien. ${ }^{252}$

"Voortgezette zwakzinnigenzorg is noodzakelijk, in tal van gevallen zal hulp moeten worden verleend. Waarin die hulp zal kunnen of moeten bestaan, kan een nadere beschouwing der afzonderlijke gevallen slechts duidelijk maken. ${ }^{.253}$

Om te kunnen bepalen wat voor hulp oud-leerlingen van het BLO nodig hadden, ontwikkelde de commissie een classificatie aan de hand van de problematiek die speelde. Dit leidde tot een verdeling in vijf groepen:

"In Groep A uit hoofde van: bijna geheele arbeidsongeschiktheid. In Groep B uit hoofde van: belangrijk verminderde arbeidsgeschiktheid. In Groep C uit hoofde van: het milieu. 
In Groep D uit hoofde van: karakter en gedragsfouten.

In groep $\mathrm{E}$ uit hoofde van : anti-sociale eigenschappen of aard der werkzaamheden." 254

De commissie paste deze classificatie toe op de Haarlemse oud-leerlingen van het BLO (zie tabel 8).

\section{Tabel 8}

Classificatie van oud-leerlingen in Haarlem naar aanleiding van oorzaak van de hulpvraag $1923^{255}$

\begin{tabular}{llll}
\hline Groep & hulp nu & $\begin{array}{l}\text { hulp in de } \\
\text { toekomst }\end{array}$ & Totaal \\
A arbeidsongeschikt & 17 & 7 & 24 \\
B verminderd arbeidsgeschikt & 28 & 13 & 41 \\
C slecht milieu & 37 & 5 & 42 \\
D karakter-en gedragsfouten & 33 & 10 & 43 \\
E antisociale eigenschappen & 9 & 3 & 12 \\
\hline
\end{tabular}

De groepen A en B, de arbeidsongeschikten en de verminderd arbeidsgeschikten, werden nader bekeken. Van deze oud-leerlingen werd onderzocht waarom ze niet of verminderd in staat waren om te werken. Daaruit bleek, dat imbecilliteit, lichamelijke gebreken en psychische afwijkingen daarin een ongeveer gelijk aandeel hadden. Imbecillen waren voor het merendeel in het geheel niet tot arbeid in staat. Oud-leerlingen met lichamelijke en psychische gebreken waren over het algemeen verminderd arbeidsgeschikt. ${ }^{256}$

Van elke categorie oud-leerlingen schetste de commissie het toekomstperspectief zoals dat volgens haar eruit zou zien als er geen hulp werd geboden. Ook gaf men aan hoe de hulp eruit moest zien als men ze in de maatschappij wilde handhaven.

Over groep A, de oud-leerlingen die niet tot arbeid in staat waren, was de commissie erg pessimistisch.

Hun verstandelijk peil is te laag, dan dat zij in een gewone werkplaats tusschen normaal personeel zouden kunnen verblijven. Zij zijn door hun onhandigheid niet in staat, behalve bij langdurig en systematisch onderricht misschien, eenvoudige handgrepen voor een vak te leeren. Enkele zijn daarbij nog teruggezet door lichamelijke gebrekkigheid, terwijl bij één oud-leerling met vrij veel arbeidsgeschiktheid het zenuwleven dermate gestoord is, dat van plaatsing in een gewone werkplaats geen sprake kan zijn.

Deze kinderen zullen na korter of langer tijd, indien niet op een of andere wijze in hun behoefte aan arbeid wordt voorzien, op gestichtsverzorging aangewezen zijn. Niet alleen, omdat voor enkele dezer leerlingen het zwerven langs de straat tot ingrijpen van de gemeenschap aanleiding zou moeten zijn, maar ook, omdat het verzorgen thuis van deze zwakzinnigen onmogelijk of bijna onmogelijk wordt, indien zij niet door werk een behoorlijke dagverdeeling hebben. ${ }^{257}$

De commissie stelde, dat aan leden van deze groep een zinvolle dagbesteding geboden moest worden om te voorkomen dat zij op den duur in een gesticht moesten worden geplaatst. 
Van groep B, de verminderd arbeidsgeschikten, stelde de commissie dat het voor een deel van deze groep mogelijk was om in loondienst te werken. Mocht dat geen haalbare kaart zijn, dan was de kans groot dat ze afhankelijk zouden worden van de armenzorg of in een gesticht geplaatst moesten worden. Volgens de commissie moest

"..getracht worden, ondanks mindere geschiktheid een milieu te vinden, waar zij op den duur een meer of minder belangrijk deel van hun onderhoudskosten zelf kunnen verdienen. Getracht moet worden hen in hun werkplaats te handhaven, zoodat zij in het bedrijf opgroeien en er op den langen duur gehouden kunnen worden. Het zijn alleen zwakzinnigen waarvan de productiviteit, als er geen hulp wordt verstrekt, tot een minimum beperkt blijtt; een groep, die een maal volwassen en niet meer in hun huiselijk milieu, op de hulp van openbare kassen of van de liefdadigheid zijn aangewezen." ${ }^{258}$

Tegen verminderd loon en met intensieve begeleiding zou deze groep min of meer zelfstandig kunnen functioneren.

Groep C, waarvoor de bron van problemen vooral in het 'milieu' lag, het gezin van herkomst en de sociale omgeving daar direct omheen, was volgens de commissie moeilijk te helpen. Er was vaak sprake van verwaarlozing en ingrijpen op grond van de kinderwetten mocht hier zeker niet uitgesloten worden.

"Het milieu is soms van dien aard dat alleen zeer ingrijpende maatregelen zullen kunnen helpen. Niet vergeten mag worden, dat in bepaalde gevallen achterlijkheid van de kinderen een van de ouders geërfde zwakzinnigheid is. In die gevallen is van een invloed ten goede door het milieu op het kind uitgeoefend, geen sprake. Voor de kinderen van deze groep is invloed van buiten op het milieu en zeker op den oud-leerling noodig om hem maatschappelijk "veilig" te houden. Ook hier komt de hulp, ten opzichte van de plaatsing naar voren, omdat regelmatige arbeid in een goede omgeving een sterk tegenwicht tegen de verkeerde invloed uit het milieu kan zijn." ${ }^{259}$

Intensieve begeleiding, in combinatie met een goede arbeidsplaats, zouden volgens de commissie kunnen helpen om volledige ontsporing tegen te gaan. Gezinsvoogdij en ontheffing of ontzetting uit de ouderlijke macht waren maatregelen waartoe overgegaan moest worden als dat nodig was.

De oud-leerlingen uit groep D, met karakter- en gedragsfouten, liepen ook groot risico om geheel te ontsporen en uiteindelijk in een gesticht terecht te komen.

"In de vierde groep (GROEP D) (...) komen de leerlingen voor, die door karaktereigenschappen in de werkplaats zoowel als thuis, aanstoot geven en daarvoor aan maatschappelijke bruikbaarheid aanmerkelijk inboeten; die bovendien door hun slechte aanleg en gedragsfouten gemakkelijk door anderen meegetroond worden.

Toezicht op, contact met en daardoor invloed op deze zwakzinnigen is noodzakelijk, om hen maatschappelijk geschikt te doen worden en te houden. ${ }^{260}$

Voor deze groep was vooral veel toezicht nodig. Mocht het misgaan, dan moest er direct worden ingegrepen om erger te voorkomen.

In groep $\mathrm{E}$ waren de oud-leerlingen ondergebracht met een bijzonder ernstige vorm van karakter- en gedragsfouten. Zij waren antisociaal en liepen daardoor 
een bijzonder grote kans om crimineel te worden.

"In de vijfde groep (...) zijn oud-leerlingen genoteerd, waarvoor op grond van antisociale eigenschappen streng toezicht noodzakelijk is, of aan wie op grond van het werk, waarin zij niet mogen blijven, hulp geboden moet worden.

De karakterfouten zijn in deze gevallen van dien aard, dat de oud-leerlingen daardoor onmaatschappelijk dreigen te worden. Hieronder komen eenige crimineele zwakzinnigen voor en anderen voor wie groote kans bestaat het te worden." ${ }^{261}$

Om te voorkomen dat deze groep inderdaad naar de criminaliteit zou afglijden, was een bijzonder intensieve vorm van toezicht noodzakelijk, in combinatie met snel ingrijpen bij problemen.

\subsubsection{Oplossingen}

Nu de toestand van de Haarlemse oud-leerlingen van het BLO geïnventariseerd was en de commissie had vastgesteld wat voor hulp aan welke categorie oudleerlingen gegeven moest worden, kwam zij nu toe aan de vraag, hoe die hulp concreet ingevuld moest worden. De commissie stelde voor, de zorg aan oudleerlingen van het BLO in vier verschillende vormen te verlenen, te weten avondonderwijs, maatschappelijke hulp, een verbandscommissie en een werkinrichting. Ook ging de commissie in op de vraag, of een vakopleiding voor oudleerlingen van het $\mathrm{BLO}$ zinvol was.

\section{A. Avondonderwijs}

Als eerste stelde de commissie Nazorg in den vorm van Avondonderwijs voor, zoals deze al in Haarlem bestond. Daarbij wilde de commissie dat de nadruk werd verschoven van het bijbrengen van schoolse kennis naar gezelligheid en het uitoefenen van pedagogisch toezicht. ${ }^{262}$ De commissie koos nadrukkelijk voor de lijn van het inmiddels overleden schoolhoofd Hiemstra. Het avondonderwijs moest, anders dan in het reguliere onderwijs, niet gericht zijn op het vermeerderen van kennis, maar een rustpunt bieden in de harde wereld.

"De waarde van deze avondcursus als opvoedend en leidend instituut voor de oud-leerlingen is zeer groot. Meer nog dan het opgroeiende normale kind heeft de zwakzinnige, die vaak onbegrepen op de werkplaats tusschen zijn kameraads (?) leeft, die zijn plaats daar moeilijk weet te vinden, daar bijkans steeds zich, terecht of ten onrechte, het mikpunt voelt van spotternijen en plagerijen, die meestal de zedelijke remmen mist om zich tegen zijn booze opwellingen en neigingen te verzetten, meer nog dan de normale heeft de zwakzinnige de opwekking noodig, die uitgaat van het verkeer met gelijkgezinden en gelijkaangelegden, onder leiding van hun goedgezinde onderwijzers, die hun vertrouwen hebben, op een plaats, waar voor hen veel aangename herinneringen verbonden zijn, n.I. de school. ${ }^{.263}$

De drempel tot het avondonderwijs moest zo laag mogelijk zijn. De rol van het onderwijzend personeel was erg belangrijk om een veilige en vertrouwde sfeer te creëren. ${ }^{264}$

De commissie ging maar beperkt in op de vraag, hoe het avondonderwijs precies moest worden ingevuld. Dat moesten de onderwijzers zélf gaandeweg ontwikkelen aan de hand van de praktijk. ${ }^{265}$ Wel gaf de commissie enkele aanwijzin- 
gen over de vorm van het onderwijs. Het zou minstens twee avonden per week moeten worden gegeven. Eén avond moest dan besteed worden aan scholing en nuttige zaken als koken, strijken, naaien, timmeren en tekenen. Het expliciete doel was, hiermee de nazorgpupillen te oefenen in deze handelingen en daardoor hun zelfvertrouwen op te bouwen.

"Hier produceeren ze iets. Ze voelen in staat te zijn, om wat voort te brengen en juist dat geeft hen de kracht, om voort te gaan en tevens steun om in het dagelijksch leven vol te houden." 266

De tweede avond moest worden ingevuld als een ontspanningsavond, met de nadruk op gezelligheid, waarin de onderwijzer een vertrouwensband met zijn pupillen zou kunnen opbouwen.

"Dan is de gelegenheid er voor den onderwijzer, om nader tot zijn leerlingen te komen en menig vertrouwelijk gesprek vindt er dan plaats." ${ }^{267}$

Bij toelating tot het avondonderwijs zouden imbecillen voorrang moeten krijgen, omdat zij het hardste steun en leiding nodig zouden hebben. Van de debielen werd verondersteld, dat de meesten van hen overdag werkten en daardoor voldoende afleiding hadden.

\section{B. Maatschappelijke hulp}

Het tweede onderdeel van de nazorg dat door de commissie werd genoemd was het regelmatig toezicht en maatschappelijke hulp, het kernstuk van de nazorg voor oud-leerlingen van het BLO. Het doel ervan was tweeledig:

"Systematisch zal moeten worden getracht de maatschappij tegen de zwakzinnigen en de zwakzinnigen tegen zichzelf te beveiligen."

Naar aanleiding van de inhoudelijke kritiek, die C. Visser in 1922 op de aanstelling van een nazorgambtenaar had gehad, behandelde de commissie allereerst uitgebreid de vraag, welke achtergrond zo'n ambtenaar zou moeten hebben. De commissie was het met Visser eens, dat de onderwijzer, die een kind meerdere jaren in de klas had gehad, de meest geschikte persoon was om nazorg te verlenen. ${ }^{269}$ De commissie stelde dat in middelgrote gemeente in de eerste jaren na de opening van de school de BLO-onderwijzers het meest geschikt waren voor deze taak. Maar in grotere steden en na langere tijd ging het aantal oud-leerlingen de draagkracht van de onderwijzers te boven. Dan kwam de hulpverlening aan de oud-leerlingen in het gedrang.

"Wisseling en vertrek van leerkrachten zou voor belangrijke groepen zwakzinni-
gen de Nazorg kunnen doen ophouden; toevallige plaatsing in bepaalde klassen
zouden enkele leerkrachten overmatig kunnen belasten, waarvan slechte of hal-
ve Nazorg het gevolg zou zijn; leerkrachten, die voor dit werk zich zelf minder
geschikt of minder geroepen zouden gevoelen, zouden toch daarmede worden
belast. Versnippering en verspilling van tijd en moeite en weinig zekerheid van
goede behartiging van de 'Nazorg' zouden uit deze regeling voortvloeien."

De commissie stelde daarom voor om de nazorg zoveel mogelijk in één hand te houden, zodat het overzicht over alle oud-leerlingen in een plaats behouden bleef en er meer deskundigheid en ervaring zou kunnen worden opgebouwd: 
“... ongetwijfeld zal de veelvuldige ervaring van de Nazorg ten goede komen en wat van nog meer belang is: steeds zal de zwakzinnige bij den zelfden persoon om hulp en steun moeten komen, wat zonder twijfel het opvoedende karakter en den invloed van deze persoonlijke omgang ten goede moet komen. ${ }^{271}$

Deze persoon moest wel deskundig zijn op het gebied van zwakzinnigheid en op de hoogte zijn van de gang van zaken op de scholen voor BLO.

De taken die deze persoon zou moeten uitvoeren, waren veelvuldig. De hand van Pier de Boer in de beschrijving ervan is duidelijk, ze vormen een uitwerking van zijn werkwijze zoals hij die in Amsterdam had ontwikkeld. Centraal stond het begeleiden van oud-leerlingen tijdens de eerste periode na het verlaten van de school, waarin intensief contact nodig was met de oud-leerling, diens ouders en de werkgever. ${ }^{272}$

Tijdens deze periode kon de nazorgambtenaar beoordelen hoe de verhoudingen in de thuissituatie van de oud-leerling waren. Hij kon ouders helpen beter om te gaan met hun kind, maar ook, als dat echt nodig was, ingrijpen en de kinderbescherming inschakelen.

"In vele gevallen zal toezicht en vermaning voor individu en milieu onvoldoende zijn, en alleen met behulp van wettelijke macht (...) een behoorlijk resultaat te bereiken zijn. ${ }^{273}$

Mocht het voor een oud-leerling, om wat voor reden dan ook, niet meer mogelijk zijn om bij de ouders te blijven wonen, dan zou de ambtenaar voor een andere woonomgeving moeten zorgen. ${ }^{274}$

Verder moest de ambtenaar voor de nazorg er voor zorgen, dat mannelijke oud-leerlingen werden vrijgesteld van militaire dienst. Bij aanraking van een oudleerling met justitie of politie moest hij ingrijpen. ${ }^{275}$

Voor het eerst werd er ook speciale aandacht besteed aan de meisjes, die tot dan toe in de nazorg vrijwel buiten beschouwing waren gebleven. De commissie vond dat het de voorkeur verdiende, hen te plaatsen in betrekkingen waarin ze huishoudelijke arbeid moesten verrichten. Tewerkstelling op een fabriek, in een grote, onoverzichtelijke arbeidssituatie, werd ten zeerste afgeraden.

"De Commissie meent, dat bij voorkeur vrouwelijke oud-leerlingen in het huisgezin als dag-en dienstmeisje te werk gesteld moeten worden.

Indien de kinderen daarbij worden geplaatst in een behoorlijke omgeving, dan is de waarschijnlijkheid, dat de kinderen in hun eigen onderhoud kunnen voorzien, het grootst. Werken in fabriek of werkplaats, (en dan in den regel in de groote groep) brengt voor onze onevenwichtigen te groote gevaren mede. Een systematische voorbereiding voor huishoudelijk werk is daarom voor de zwakzinnige meisjes ten zeerste gewenscht. ${ }^{276}$

Grote nadruk legde de commissie op de taak van de ambtenaar om verwijdering van oud-leerlingen van het BLO uit de maatschappij te voorkomen. Plaatsingen in gestichten moesten worden voorkomen, maar de ambtenaar moest ook bevorderen dat oud-leerlingen uit gestichten terug in de maatschappij werden geplaatst. De nazorgambtenaar had ook een taak bij ontslag van oud-leerlingen van het BLO uit gevangenis of gesticht bij voorwaardelijke veroordelingen. ${ }^{277}$ 


\section{Verbandscommissie}

Om de nazorg zo effectief mogelijk te laten zijn, pleitte de commissie De Boer voor samenwerking met patronaten en andere verenigingen. De nazorgambtenaar moest contact zoeken met de jeugdorganisaties van de verschillende levensbeschouwingen om een netwerk te vormen, dat gericht moest zijn op die oud-leerlingen die het avondonderwijs niet of niet meer bezochten:

"Voor deze oud-leerlingen zou een 'tehuis' (...) waar zij hun gelijkberechtigden zouden ontmoeten en tevens een doelmatige en aangename ontspanning zouden kunnen vinden, een zegen zijn. ${ }^{278}$

De commissie stelde voor om samenwerking te zoeken met de in Haarlem actieve jeugd- en jongerenorganisaties.

"De zes jongenspatronaten, de zes meisjespatronaten en de drie Sint-Josephgezellenvereenigingen der Roomsch-Katholieken, de Gereformeerde en Christelijkgereformeerde Knapen- en Jongelingsvereenigingen, het Jongensgilde en andere vereenigingen. ${ }^{279}$

Er zou een Verbandscommissie moeten worden opgericht om de problemen rondom zwakzinnigen samen te bespreken en op te lossen.

\section{Werkinrichting}

Belangrijk onderdeel van de nazorg achtte de commissie een werkinrichting voor de maatschappelijk ongeschikte zwakzinnige oud-leerlingen. $\mathrm{Zij}$ pleitte voor de heroprichting van een werkplaats zoals die van de Spaarnestichting.

"De werkinrichting bedoelt (...) te zijn een inrichting, die op sociaal-ongeschikte oud-leerlingen der school voor Buitengewoon Onderwijs een opvoedende invloed wil uitoefenen door hen regelmatige arbeid te verschaffen., ${ }^{280}$

Tot deze sociaal ongeschikte oud-leerlingen behoorden de geheel arbeidsongeschikten uit groep A en enkele belangrijk verminderd arbeidsgeschikten uit groep B. Voor de toelating mocht de productiviteit van een oud-leerling geen rol spelen, eerder het ontbreken ervan.

Winst maken mocht volgens de commissie geen doelstelling zijn. Zij ging ervan uit, dat een werkinrichting altijd extra geld nodig zou hebben, afkomstig van de overheid of particulieren. ${ }^{281}$

De commissie legde de prioriteit bij een werkinrichting voor jongens, omdat zij eerder gevaar liepen om tot a- of antisociaal gedrag te vervallen.

"De leeftijd, het voorbeeld en den omgang met anderen beginnen verlangens in hun wakker te roepen: zij beginnen eischen te stellen (rooken, bioscoop, kleeding) en kennen als zwakzinnigen maat noch redelijkheid.

Een doorloopend toezicht, zooals dit eigenlijk noodig is, kan in den regel niet worden uitgeoefend, zoodat de met de zorg belaste ouders in voortdurende vrees leven voor ongelukken, slechte connecties, politie aanraking enz. ${ }^{282}$

Meisjes liepen volgens de commissie op dit gebied een kleiner risico. Daarnaast vond de commissie gestichtsopname voor meisjes een minder groot probleem.

"...deze kinderen [worden] thuis gemakkelijker bezig gehouden, terwijl zij, doordat zij op huiswerk zijn aangewezen, ook minder gemakkelijk hun fortuin op 
straat zoeken. Daarbij komt nog, dat voor die meisjes, waarbij aanpassen in de huiselijke omgeving onmogelijk blijkt en langs de straat loopen gewoonte wordt, eerder in haar eigen belang overgegaan wordt tot gesloten (gestichts)verzorging, met het oog op sexueele handelingen of conflicten." ${ }^{283}$

Op termijn werd een werkinrichting voor meisjes noodzakelijk geacht, als er meer vrouwelijke oud-leerlingen zouden zijn.

Het belangrijkste doel van deze werkinrichting moest het tegengaan van gestichtsopnamen zijn. De heilzame werking van arbeid, de gunstige invloed van de afwisseling van inspanning en rust en het hebben van een nuttige dagbesteding konden dat volgens de commissie bewerkstelligen. ${ }^{284}$ Als een oud-leerling niet naar een inrichting hoefde, was dat allereerst in het belang van de betrokkene zelf:

"Met verwijdering uit de maatschappij grijpen wij zeer diep in het leven ook van den abnormale, want een groot deel van het maatschappelijk en familieleven wordt daarmede voor het individu onbereikbaar. ${ }^{\circ 285}$

Het was ook in het belang van de maatschappij als geheel. De kosten van gestichtsverpleging gingen erdoor omlaag, tegelijkertijd droegen oud-leerlingen door hun arbeid bij aan de welvaart van de samenleving als geheel.

Het was niet de bedoeling, dat de werkinrichting het karakter zou krijgen van een arbeidsschool. Het was inmiddels duidelijk, waarschijnlijk op grond van de ervaringen die in Amsterdam waren opgedaan, dat vrijwel alle tewerkgestelden op een werkinrichting niet naar het bedrijfsleven zouden doorstromen. De werkinrichting moest permanente arbeidsplaatsen bieden.

De commissie stelde, dat de arbeid die op een werkinrichting verricht werd aan een aantal voorwaarden moest voldoen. Het moest inspanning vergen, eenvoudig zijn en fouten moesten makkelijk hersteld kunnen worden. Daarnaast moest er voor het eindproduct een markt bestaan. Activiteiten als kokosmatten vlechten en borstels maken voldeden volgens de commissie aan deze criteria.

Op het punt van de beloning stelde de commissie zich op het standpunt, dat er een vorm van financiële prikkeling voor de tewerkgestelden moest bestaan.

"..op het punt van hun "verdiende loon" zijn de zwakzinnigen minstens even gevoelig als de normalen en als prikkel tot ingespannen arbeid is deze uitkeering van groot belang. ${ }^{286}$

De commissie adviseerde de Haarlemse gemeenteraad tenslotte, een werkinrichting door het particulier initiatief te laten exploiteren, omdat deze flexibeler zou kunnen opereren dan een gemeentelijke dienst. ${ }^{287}$

\section{E. Vakopleiding}

Ten slotte ging de commissie nadrukkelijk in op de vraag of een vakopleiding voor oud-leerlingen van het BLO zin had. Daarbij bracht de commissie een scheiding aan tussen jongens en meisjes. Met betrekking tot de jongens deed de commissie onderzoek naar de oud-leerlingen van de Rotterdamse ambachtscursussen, door mij al in paragraaf 1.3.2 aangehaald. Daaruit kwam naar voren dat vrijwel geen van hen werkte in het vak waarvoor ze waren opgeleid en dat hun lonen vaak vér onder het normaal gangbare lagen. De commissie concludeerde hieruit, dat oud-leerlingen van het BLO slechts bij zéér hoge uitzondering geschikt te maken waren voor ge- 
schoolde vakarbeid. ${ }^{288}$

"Zij kunnen zonder groot risico van mislukken niet zelfstandig handelen: bij opdrachten, die een dieper doordenken of grooter zelfstandigheid bij de uitvoering vereischen zijn zij zonder uitzondering ongeschikt. ${ }^{289}$

Om deze stelling verder te onderbouwen deed de commissie onderzoek naar de vraag, in welke beroepen mannelijke oud-leerlingen van het BLO het beste functioneerden. Dat bleek vooral ongeschoolde fabrieksarbeid te zijn. Toch vond de commissie fabrieksarbeid ongewenst:

"... over het algemeen is deze arbeid te afmattend, terwijl vele onzer leerlingen juist aan aandachtsstoornissen lijden..." ${ }^{290}$

Verder stond men huiverig tegenover fabrieksarbeid vanwege de grootte van de schaal waarop er arbeid werd verricht en de daardoor moeilijk controleerbare relaties met collega's op de werkvloer.

"In den regel worden zij (de oud-leerlingen, LB) het mikpunt van grappen en spotternijen (....) Prikkelbare naturen kunnen daarom niet in dit werk ondergebracht worden....

De commissie vond daarom vooral ongeschoolde arbeid in een kleinschalige omgeving het meeste geschikt. Jongens die daarin werkten functioneerden over het algemeen goed. De commissie vond daarom een vakopleiding voor mannelijke oud-leerlingen van het BLO overbodig. Belangrijkste argument daarbij was dat geschoolde arbeid voor vrijwel alle oud-leerlingen té hoog gegrepen was. Slechts een enkeling was ervoor geschikt, die kon volgens de commissie daarom beter in het reguliere ambachtsonderwijs geplaatst worden en daar een aangepast lesprogramma krijgen. ${ }^{292}$

Voor meisjes vond de commissie een voortgezette opleiding wél noodzakelijk. Het ging voor hen niet om een opleiding tot het verrichten van geschoolde arbeid, maar om het aanleren van huishoudelijk werk. De commissie veronderstelde dat het merendeel van de meisjes daarin terecht zou komen.

Voortgezet huishoud-en kookonderwijs lijkt de Commissie voor bijna alle meisjes noodzakelijk; niet het minst ook voor die vrouwelijke leerlingen, die (nog) niet bij een vreemde in huishoudelijk werk kunnen worden geplaatst. ${ }^{.293}$

Alle meisjes van de scholen voor BLO kwamen ervoor in aanmerking.

\subsection{Reacties op het rapport}

Het rapport van de Commissie-De Boer, dat bekend werd onder de naam Haarlems Nazorgrapport, riep veel reacties op. Het was tot op dat moment het meest diepgravende rapport over de zorg voor oud-leerlingen van het BLO, zowel voor wat betreft het onderzoek naar hun leefomstandigheden en hun behoefte aan hulp, alsook naar de manier, waarop die hulp ingericht zou kunnen worden. Met het rapport had De Boer een programma voor de nazorg ontwikkeld dat het Haarlemse verre oversteeg en de ontwikkeling van de nazorg in Nederland in belangrijke mate zou beïnvloeden.

Schuurmans Stekhoven, de inspecteur van het krankzinnigenwezen die de 
noodzaak van het aanstellen van een nazorgambtenaar had betwijfeld, had het moeilijk met het rapport. In een reactie uit 1924 bleef hij sceptisch over het nut van een ambtenaar voor de nazorg.

"Het rapport zoude, dunkt mij, aan beteekenis nog gewonnen hebben, wanneer de hoofdvraag, waar het om ging, op den voorgrond was gesteld. Die hoofdvraag was niet: is voortgezette zwakzinnigenzorg noodig? (...)

De hoofdvraag was eigenlijk: is het noodig, dat voor de belangen der oud-leerlingen van de buitengewone school een ambtenaar wordt aangesteld?"294

Hij vond dat de onderwijzers van het BLO het meest geschikt waren om de nazorg uit te voeren, waarbij een verbandscommissie kon dienen om de grootste probleemgevallen verder te helpen.

"Dat de onderwijzer van de buitengewone school niet zooveel kan doen als hij gaarne zou willen, heeft de Commissie wel duidelijk gemaakt, maar dat niet van andere zijde, door patronaten en andere vereenigingen, welke de Commissie met den ambtenaar wil laten samenwerken, in een stad als Haarlem voorloopig voldoende gezorgd zoude kunnen worden voor aanvulling, waar de onderwijzer te kort schiet, heeft de Commissie, dunkt mij, niet op overtuigende wijze aangetoond. ${ }^{295}$

Toch moest Schuurmans Stekhoven toegeven, dat het rapport degelijk was onderbouwd en een goede basis voor de ontwikkeling van de zorg voor oud-leerlingen van het BLO vormde. Hij sloot zijn commentaar af met een min of meer waarderend woord voor de schrijvers van het rapport op het punt van de noodzaak van een werkinrichting.

"Afgezien van godsdienstige en zedelijke factoren, welke bij elke bemoeienis met menschen een belangrijke rol moet spelen, is bij de zorg voor zwakzinnigen arbeid numero één.

We willen hopen, dat Haarlem spoedig weder in het bezit is van een arbeidsschool, welke zich verheugen mag in de levendige belangstelling en den krachtigen steun van den Raad dier gemeente. ${ }^{296}$

A. van Voorthuijsen, de inspecteur van het BLO, schreef een maart 1925 een artikel dat heel wat positiever van toon was. Hij beschouwde het rapport als een belangrijke leidraad voor de ontwikkeling van de zwakzinnigenzorg in heel Nederland.

\begin{abstract}
"Hoewel wij in de verste verte nog niet zoover zijn, dat van de enigszins voldoende zwakzinnigenzorg kan worden gesproken, teekent zich toch zoo langzamerhand de lijn af, die wij bij het nemen van maatregelen hebben te volgen. De indruk, dat dit inderdaad zoo is, wordt versterkt door de lezing van het rapport, dat is uitgebracht, door de Commissie, ingesteld door den Gemeenteraad van Haarlem, ten einde te onderzoeken wat te Haarlem kan geschieden voor de nazorg van de oud-leerlingen der school voor buitengewoon lager onderwijs. ${ }^{.297}$
\end{abstract}

Het belangrijkste inhoudelijke meningsverschil dat hij met de schrijvers van het rapport had, ging over het belang van een vakopleiding voor zwakzinnigen. Daar was hij een voorstander van. Hij vond dat de commissie het aantal oud-leerlingen van het BLO dat daarvoor in aanmerking kon komen onderschatte. ${ }^{298}$ Dat vormde echter geen belemmering voor hem om de grote waarde van het rapport voor het 
BLO en de nazorg te erkennen:

"De lezing van het rapport, dat ongetwijfeld voor het grootste gedeelte is opgesteld door den heer P. de Boer, Voorzitter der Commissie en tevens Ambtenaar voor de nazorg te Amsterdam, kan worden aanbevolen aan ieder, die met het zwakzinnigen-vraagstuk in aanraking komt. Het leert ons, dat hulp voor de oudleerlingen der scholen voor zwakzinnigen noodig is en het wijst ons den weg naar de middelen, die het normale gedeelte der samenleving in het belang van de geestelijk minderwaardigen in haar midden heeft aan te wenden. ${ }^{299}$

Het Haarlemse nazorgrapport was veelomvattend. Het bevatte een onderzoek naar de levensomstandigheden van oud-leerlingen van het BLO, een inventarisatie van de problemen waarmee zij te maken kregen en een classificatie van oud-leerlingen, waarin zowel aandacht was voor hun persoonlijke problematiek als hun geschiktheid om in de maatschappij te functioneren. Verder beschreef het een aantal middelen, die voor de nazorg ingezet zouden kunnen worden, waarvan de belangrijkste waren: een nazorgambtenaar, een werkinrichting, avondverzorging en overleg met verschillende jeugd- en jongerenorganisaties.

\subsection{Definitieve regeling van de Haarlemse nazorg}

Op 4 februari 1924 bracht de commissie De Boer haar nazorgrapport uit. Op 8 oktober 1924 werd het rapport door de Gemeenteraad integraal overgenomen. In de tussenliggende periode organiseerde E.P. Schuyt, onderwijzer aan het BLO en medeopsteller van het rapport, de avondverzorging waarvan hij vervolgens zelf het hoofd werd. $^{300}$

Dezelfde Schuyt werd op 4 maart 1925 aangesteld als Ambtenaar voor de Nazorg, in tijdelijke dienst tot 1 november 1925. In deze periode moest hij de Haarlemse nazorg opstarten. Hij kreeg daarbij de opdracht om over de verschillende aspecten ervan een vijftal rapporten te schrijven, aan de hand waarvan de Gemeenteraad zou besluiten over de definitieve regeling van de nazorg in de stad. ${ }^{301}$

Deze rapporten verschenen in de loop van 1925 . Ze waren vooral een verdere inhoudelijke en praktische uitwerking van het nazorgrapport. Het eerste rapport ging over de wijze, waarop de ambtenaar voor de nazorg de gegevens van zijn pupillen moest vastleggen en bijhouden. Het handelde over de wijze waarop verschillende kaarten moesten worden ingevuld en bijgehouden en opgeslagen in verschillende archieven. ${ }^{302}$

In het tweede rapport behandelde Schuyt de organisatie en invulling van de Verbandscommissie. Deze werd medio 1925 opgericht en kende in totaal 17 deelnemende organisaties van alle mogelijke gezindten. Schuyt omschreef het doel van de commissie, in aanvulling op wat in het nazorgrapport was vermeld,

\section{"... om met en naast den Ambtenaar de paedagogische-zedeliike en godsdien- stige Nazorg te behartigen. ${ }^{-303}$}

Tot plenaire bijeenkomsten zou het nooit komen. De nazorgambtenaar nam met een deelnemende organisatie contact op, als daarvoor met betrekking tot een nazorgpupil concrete aanleiding bestond. ${ }^{304}$ Veel stelde de Verbandscommissie hierdoor niet voor; ze was vooral te beschouwen als een onderdeel van het netwerk van de nazorgambtenaar dat hij inzette bij de maatschappelijke zorg aan zijn pupillen. 
Het derde rapport was een verslag van Schuyt's werkzaamheden voor de Haarlemsche Werkinrichting, die in juli 1925 openging en, in tegenstelling tot de aanbevelingen van het nazorgrapport, was opgezet als een gemeentelijke instelling. ${ }^{305}$ De gemeente besloot deze, na vergelijking met de subsidiëring van de Dordtse werkinrichting, een budget van fl.2000,- $(€ 850,-)$ per jaar mee te geven. ${ }^{306}$

In het vierde rapport ging Schuyt in op de huishoudcursus voor onhandige en maatschappelijk ongeschikte meisjes, die in 1926 van start zou gaan. ${ }^{307}$ Deze cursus was tijdelijk van aard, omdat in het BLO voor meisjes meer aandacht zou komen voor de praktijk van de huishoudelijke arbeid.

Het laatste rapport ging over subnormalen, kinderen uit het gewoon lager onderwijs die daar slecht presteerden en daarom voor nazorg in aanmerking kwamen Schuyt stelde vast, dat er in Haarlem een aanzienlijke groep van deze kinderen bestond en dat een deel van hen, net zoals de oud-leerlingen van het BLO, eveneens behoefte had aan steun in de maatschappij na het verlaten van de school. ${ }^{308}$

Deze vijf rapporten, die samen een verslag van werkzaamheden van Schuyt gedurende zijn tijdelijke aanstellingen vormden, leidden ertoe dat de gemeenteraad op 29 oktober 1925 de nazorg in Haarlem definitief regelde. Men besloot,
"In het leven te roepen eenen tak van dienst, de nazorg voor zwakzinnigen in de- ze gemeente, zoowel meisjes als jongens, ten doel hebbend; (daaronder te ver- staan, - nevens de leerlingen en oud-leerlingen der openbare en bijzonder scho- len voor buitengewoon lager onderwijs, - de kinderen, die de lagere school we- gens zwakte van geestvermogens van uit de $5 \mathrm{e}$ of een lagere klasse verlaten hebben, z.g. 'subnormalen');:"309

Alle aanbevelingen uit het rapport van de commissie De Boer en de deelrapporten van Schuyt werden overgenomen. B\&W gaf Schuyt verder de opdracht, de nazorg te verzorgen

"... ten aanzien van hen, die niet direct tot de zwakzinnigen of subnormalen gerekend kunnen worden, en toch steun behoeven (bijv. de psychopathen). ${ }^{31}$

Hiermee was de doelgroep van de Haarlemse nazorg groter dan alleen de oudleerlingen van het BLO en omvatte ook een groep, waarvoor in Amsterdam F.S. Meijers verantwoordelijk was. Er zijn echter geen aanwijzingen dat Schuyt zijn zorgen ook daadwerkelijk naar deze groep uitbreidde. 

"Wij zitten met de nazorg in een trekschuit en wij roepen tot de mannen, als De Boer, Frantsen en Wepster, om toch vooral niet te hard te trekken, daar ongelukken zullen gebeuren, als de vaart van het schip te hoog wordt opgevoerd. "

A. van Voorthuijsen, $1929^{31}$

In dit hoofdstuk behandel ik de ontwikkeling van de nazorg in de tweede helft van de jaren twintig. Daarbij probeer ik de ontwikkelingen in het gehele land weer te geven zonder me op één specifieke nazorginstelling te concentreren.

$\mathrm{lk}$ begin met de maatschappelijke omstandigheden van de jaren twintig, waarbij ik bijzondere aandacht besteed aan de gevolgen van de afloop van de schoolstrijd voor het BLO. Daarna ga ik in op de ontwikkelingen in het denken over zwakzinnigheid bij achtereenvolgens het BLO, de sociale psychiatrie, de arbeidsvoorziening en de residentiële zwakzinnigenzorg, allemaal zorgsoorten waarmee de nazorg in meer of mindere mate te maken had. Vervolgens behandel ik de ontwikkeling van dat denken binnen de nazorg zelf.

Daarna ga ik in op de praktijk van de nazorg zoals deze zich in de jaren twintig ontwikkelde. Ik behandel de groei ervan, de financiering en de inhoudelijke en praktische ontwikkeling van de centrale onderdelen van de nazorg: maatschappelijke zorg, werkinrichtingen en avondverzorging. Ik ga apart in op de registratie van de gegevens van oud-leerlingen. Ik sluit af met een beschrijving van de onderlinge contacten die nazorgwerkers in deze periode hadden.

In dit hoofdstuk komen alle onderzoeksvragen aan de orde.

\subsection{Maatschappelijke omstandigheden in de jaren twintig}

In 1920 kwam de schoolstrijd tot een einde met de gelijkstelling van de financiering tussen openbaar en bijzonder onderwijs, in de vorm van de pacificatiewet. ${ }^{312}$ Daarmee was het belangrijkste strijdpunt van de verzuiling door de confessionele partijen gewonnen en kon het bijzonder onderwijs zich gaan ontwikkelen. Dat gold ook voor het bijzonder buitengewoon onderwijs. In 1920 waren er in totaal 7 bijzondere scholen voor BLO in Nederland, ${ }^{313}$ in 1921 waren dat er al 13 om in de loop van de jaren twintig verder toe te nemen tot 37 in $1929 .{ }^{314}$ De naam Buitengewoon Onderwijs werd, samenhangend met de invoering van de pacificatiewet, op 21 december officieel bij Koninklijk Besluit vastgesteld. ${ }^{315}$ Tegelijkertijd kwam er een apart Ministerie van Onderwijs. ${ }^{316}$

Een ander gevolg van de pacificatiewet was dat er voor het BLO op 1 januari 1921 een eigen inspecteur werd aangesteld. De keuze viel op de arts A. van Voorthuijsen. Deze voormalige schoolarts was al in 1915 betrokken geweest bij de oprichting van de Groningse afdeling van de Centrale Vereniging ter Behartiging van de Belangen van Zwakzinnigen en was enkele jaren hoofdredacteur geweest van PAIS, het blad van O\&A zoals dat rond de Eerste Wereldoorlog heette. Anders 
dan de overige inspecteurs van het lager onderwijs, die vooral moesten controleren of scholen zich hielden aan de voorgeschreven regelgeving, kreeg de inspecteur van het BLO de opdracht om de regering te adviseren over de wijze waarop het buitengewoon onderwijs ingericht zou moeten worden. ${ }^{317}$ Hierdoor had hij een relatief vrije rol, die hij onder andere benutte voor het promoten van het BLO en, daarmee samenhangend, de nazorg. Van Voorthuijsen was voorstander van een meer omvattende zorg voor zwakzinnigen dan onderwijs alleen: hij wilde dat zwakzinnigen hun gehele leven, van de wieg tot het graf, begeleid en in de gaten gehouden zouden worden. Dat betekende onder andere dat hij zich regelmatig intensief met de nazorg bemoeide. ${ }^{318}$

In de jaren twintig zette de verzuiling in Nederland verder door. Daarbij leken zich nu ook de liberalen en sociaal-democraten aan te sluiten. Er ontstonden allerlei organisaties, zoals de omroepen, van specifiek socialistische of liberale signatuur. Daarbij conformeerden de sociaal-democraten zich, na de mislukte revolutiepoging van Troelstra in 1918, definitief aan het politieke systeem van de parlementaire democratie. De sociaal-democratie werd langzaam tot een geaccepteerde maatschappelijke stroming die zich, net als de confessionelen, steeds meer als een gesloten gemeenschap ging gedragen. Ook zij probeerde de normen en waarden die haar elite inmiddels had gevormd op te leggen aan lagere sociale klassen. In deze periode ontwikkelden de sociaal-democraten een eigen hulpverleningsprogramma, dat niet zozeer de nadruk op liefdadigheid legde maar waarin veel meer kernbegrippen als 'opvoeding' en 'genezing' een rol speelden. ${ }^{319}$ Doordat de sociaaldemocraten in de grote steden in het westen van het land bestuursverantwoordelijkheid kregen, konden zij dit programma ook daadwerkelijk uitvoeren. Zo waren in Amsterdam, dat al vanaf 1914 een socialistische wethouder kende, ${ }^{320}$ zeer veel betrokkenen bij de nazorg sociaal-democratisch: naast De Boer ging het daarbij onder andere om F.S. Meijers, de directeur van de GG\&GD Heijermans en de schoolarts bij het BLO D. Herderschêe.

De regeringsmacht op landelijk niveau bleef gedurende de gehele jaren twintig in handen van confessionelen en conservatieve liberalen. De katholieken waren daarbij steevast de grootste partij. ${ }^{321}$ Economisch gezien ging het in de jaren twintig niet buitengewoon slecht - of goed - met Nederland. In de zomer van 1923 kreeg men te maken met een depressie, gevolgd door een periode van herstel die in 1925 voltooid was. Daarna begon een gestage groei van de economische bedrijvigheid, die tot aan het einde van de jaren twintig zou duren. ${ }^{322}$

\subsection{Denken over zwakzinnigen}

In de tweede helft van de jaren twintig groeide de belangstelling voor zwakzinnigen en zwakzinnigheid buiten de kaders van BLO en residentiële zwakzinnigenzorg. Dat was vooral het geval bij de sociale psychiatrie en de arbeidsvoorziening. Deze belangstelling kwam voort uit het feit, dat deze disciplines in de praktijk van hun dagelijks werk met mensen die als zwakzinnig werden geclassificeerd te maken kregen. Ik zal in deze paragraaf ingaan op de opvattingen die bij het BLO, de sociale psychiatrie, de arbeidsvoorziening en de residentiële zwakzinnigenzorg bestonden en de relatie die zij tot de nazorg hadden. 


\subsubsection{BLO en zwakzinnigheid}

Voor de jonge nazorg was het BLO het belangrijkste referentiekader voor het denken over zwakzinnigheid. De definitie van zwakzinnigheid die Herderschêe had ontwikkeld werd zowel door BLO als nazorg algemeen aanvaard:

"... wij noemen een kind zwakzinnig, indien het, op grond van zijn gebrekkigen verstandelijken aanleg, onder geen omstandigheden in staat zal zijn, het einddoel van het gewone lager onderwijs te bereiken, ${ }^{, 323}$

Het ging om een relatieve definiëring, die mede afhankelijk was van de wijze waarop het onderwijs werd ingevuld: veranderde het einddoel, dan veranderde ook de grens tussen zwakzinnigheid en normaliteit. ${ }^{324}$ Een zelfde relativiteit vinden we in de definitie die voor volwassen zwakzinnigen werd gebruikt en die door Van Voorthuijsen in 1926 werd verwoord:

"Voor de maatschappij luidt de definitie (...) dat men volwassenen zwakzinnig moet noemen, wanneer zij ten gevolge van intelligentiedefecten zonder hulp van buiten niet in staat zijn in eigen levensonderhoud te voorzien." ${ }^{325}$

Als de maatschappelijke omstandigheden veranderden en daardoor ook de eisen die de maatschappij stelde aan haar leden, kon het aantal volwassen zwakzinnigen toenemen of juist dalen.

Het eugenetische gedachtegoed, dat uitging van een voorbestemdheid van zwakzinnigen tot a- of antisociaal gedrag, was in deze periode springlevend en gold als vooruitstrevend. Vooral de artsen Herderschêe en Van Voorthuijsen voelden zich door deze stroming aangesproken, maar zij pleitten niet voor eugenetische maatregelen tegen zwakzinnigen. Het geloof in de pedagogiek en de mogelijkheden van het sociaalhygiënisme had bij hen nog de overhand, net zoals bij de meeste andere betrokkenen bij het BLO. In deze periode begon er aandacht te ontstaan voor de rol van omgevingsfactoren op het gedrag van zwakzinnigen. Zo stelde A.J. Schreuder, de voorzitter van de Christelijke vereniging voor Buitengewoon Onderwijs in 1930 dat erfelijkheid niet langer een kwestie was van 'Prädestination' maar van 'Prädisposition' en dat de omgeving een veel grotere rol speelde bij het al dan niet tot ontwikkeling komen van een slechte aanleg dan tot dan toe was gedacht. $^{326}$

Daarbij bleef er wel een algemeen wantrouwen ten opzichte van zwakzinnigen bestaan. Zij behoorden onder strenge controle te staan, om bij het minste teken van ontsporing in te kunnen grijpen. In de woorden van Herderschêe zag deze opvatting er ongeveer als volgt uit:

\footnotetext{
"Misschien wordt wel de belangrijkste groep van zwakzinnigen gevormd door hen, wier aanleg, niet als bij normalen, allerlei schadelijke invloed ongestraft kan ondergaan, maar die, onder goede omstandigheden tot normale menschen kan doen opgroeien. Ook deze groep eischt dus krachtige sociaal-hygiënische maatregelen om die schadelijke invloeden te bestrijden. ${ }^{327}$
}

Daarbij maakte hij zich grote zorgen over de vraag, wat er zou gebeuren als de sociale omstandigheden ernstig verslechterden.

"Maar de abnormale aanleg zal blijven bestaan en wanneer in minder rustige tijden door oorlog of revolutie, de samenleving zou worden omgewoeld, dan zal 
misschien heel wat degeneratie naar boven komen, om den chaos te vermeerderen." ${ }^{328}$

Binnen het $\mathrm{BLO}$ bestond de overtuiging dat oud-leerlingen na het verlaten van de school verdere hulp en zorg nodig hadden. Veel BLO-onderwijzers verleenden die zorg aan hun oud-leerlingen en kenden daardoor de praktijk van dat werk. Er werd dan ook hard meegedacht over de invulling van de nazorg, dat binnen het BLO algemeen werd beschouwd als het sluitstuk van het onderwijs.

"Nazorg (...) dient een voortbouwen te zijn op de verkregen resultaten door de dagscholen ..." ${ }^{329}$

Daarbij was men er zich van bewust, dat de inhoud van het BLO-onderwijs van invloed was op de kans van slagen van haar leerlingen in de maatschappij:

"De zwakzinnigen moeten opgeleid worden met het doel productieven arbeid te kunnen leveren; de eenvoudigste arbeid heeft voor hen, evenals voor de maatschappij, een groote waarde. Het eenig mogelijke werk dat zwakzinnigen kunnen verrichten is handwerk. Het voornaamste van het onderwijs aan zwakzinnigen is niet het opstapelen van groote hoeveelheden kennis, maar het bijbrengen van arbeidslust. Het handwerk moet als toekomstig levensdoel worden gekozen." ${ }^{330}$

Daarmee was overigens niet iedereen het eens. Zo pleitte BLO-onderwijzer G.M. Grootenboer uit Amsterdam in 1927 ervoor, niet alleen aan de arbeidsgeschiktheid van BLO-leerlingen te werken:

"... we moeten onze leerlingen iets trachten mee te geven, waaraan ze in hun vrijen tijd eenige vreugde kunnen hebben. En dit is vooral een dringend vraagstuk voor de jongens in de groote steden. Maar al te vaak hooren we, dat oudleerlingen thuis het leven voor zichzelf en voor de huisgenooten verre van aangenaam maken, zoo erg soms, dat de ouders ten einde raad onze hulp komen inroepen of pogingen doen, om hun kind in een gesticht geplaatst te krijgen. Zoo ergens, dan is het in die gevallen: Ledigheid is des duivels oorkussen." ${ }^{331}$

De basishouding ten opzichte van zwakzinnigen zoals hierboven beschreven was bij de verschillende levensbeschouwelijke stromingen binnen het BLO hetzelfde. Er bestonden nuanceverschillen, die vooral betrekking hadden op de plaats die de godsdienst in het leven van zwakzinnigen behoorde in te nemen. Vooral de katholieken hadden hierover uitgesproken meningen:

"De Roomsche liefdadigheid geeft haar geld niet en vooral ook de religieuze congregaties geven hare beste krachten ook niet, om daardoor alleen te bereiken, dat hare pupillen den kost verdienen zonder met den strafrechter in aanraking te komen. Onze minimum-eisch moet zijn, dat de oud-verpleegde als roomsch mensch eene plaats in de maatschappij inneemt. Onze opvoeding is mislukt, als de oud-verpleegde de godsdienstige plichten verzuimt, al neemt hij dan nog zoo'n goede positie in de Maatschappij in. ${ }^{\text {"332 }}$

God had de zwakzinnigen geschapen en zij moesten daarom volgens de betrokkenen bij het katholieke BLO de kans krijgen om hun ziel zalig te maken en zo in de hemel te komen. ${ }^{333}$

In de weinige artikelen over het BLO die van protestants-christelijke kant bewaard zijn gebleven, legden vertegenwoordigers van deze stroming vooral de nadruk op de belangen van degenen, die zorg aan hulpbehoevenden verleenden: 
"Daarom heeft de menschenwereld tot taak en tot plicht het kleine, zwakke, minderwaardige bij te staan, te helpen en te verheffen. En deze hulp is voor de wereld niet een verlies, maar een winst. Zij is ontwikkelings-kracht, kracht die haar verfijnt, verdiept, opstuwt. ${ }^{334}$

\subsubsection{Sociale psychiatrie en zwakzinnigheid}

De oorsprong van de belangstelling voor zwakzinnigen in kringen van de sociale psychiatrie had te maken met de angst die binnen de psychiatrie als geheel bestond voor de toename van het aantal mensen met psychische afwijkingen. Men zag dat als een teken van een achteruitgang van de kwaliteit van de bevolking als geheel. Zwakzinnigheid werd als één van die psychische afwijkingen beschouwd. De angst voor degeneratie had in de jaren tien al geleid tot de oprichting van de Centrale Vereeniging ter Behartiging van de Belangen van Zwakzinnigen ${ }^{335}$ en bleef bestaan, ook na de ondergang van deze vereniging. K.H. Bouman, één van de schrijvers van het Amsterdamse After-Care-rapport, deelde deze bezorgdheid.

"Het aantal geestelijk onevenwichtigen en invaliden neemt toe en het steeds toenemen van deze minder goede elementen zal op den duur de draagkracht der valide bevolking te boven gaan. ${ }^{336}$

Om dit gevaar te bezweren was in 1924 de Nederlandsche Vereeniging ter bevordering der Geestelijke Volksgezondheid opgericht, met naast K.H. Bouman onder andere A. van Voorthuijsen en F.S. Meijers als initiatiefnemers. Onder de leden van deze vereniging bestond grote bezorgdheid over de toename van het aantal zwakzinnigen. Met hun predispositie tot criminaliteit, alcoholisme, landloperij en prostitutie zouden zij een grote belasting voor de samenleving vormen. ${ }^{337}$ Vooral de lichtzwakzinnigen werden als een probleem beschouwd, omdat zij in de moderne, jachtige stedelijke samenleving extra gevaar liepen om af te glijden. Zij vormden daarom één van de doelgroepen van de nieuwe vereniging.

De toename van het aantal mensen met psychische afwijkingen had voor de grotere gemeenten, waaronder Amsterdam en Rotterdam, ernstige financiële gevolgen. $\mathrm{Zij}$ werden geconfronteerd met een toename van het aantal mensen dat op kosten van de gemeente in gestichten moest worden ondergebracht. Zo besteedde de gemeente Amsterdam in het jaar $1900 \mathrm{fl} .26 .000$,- $(€ 11.818,-)$ aan de gestichtsverpleging van haar armlastige burgers. In 1917 was dat bedrag verviervoudigd tot fl. 107.400,- $(€ 48.818,-) .{ }^{338}$ In Rotterdam waren aan het einde van 1908 in totaal 723 mensen op kosten van de gemeente in gestichten ondergebracht. Aan het einde van 1918 was hun aantal gegroeid tot 1047 , op 31 december 1925 ging het om in totaal 1564 personen. ${ }^{339}$

Deze oplopende kostenpost leidde ertoe, dat er bij een aantal gemeenten draagvlak ontstond om op dit gebied in te grijpen. Het leidde tot het ontstaan van de sociale psychiatrie, gefinancierd door gemeenten, die zich in eerste instantie richtte op het voorkomen en terugdraaien van gestichtsplaatsingen. In dit licht moet de aanstelling van F.S. Meijers in 1917 bij de Amsterdamse geneeskundige dienst beschouwd worden: hij kreeg de opdracht om gestichtsopnamen beter te controleren dan tot dan toe gebruikelijk. ${ }^{340}$ Rotterdam had het iets eenvoudiger, omdat deze stad over een eigen krankzinnigengesticht beschikte, Maasoord in Poortugaal. De geneesheer-directeur hiervan, de psychiater J.H. Pameyer, begon in 1926 met een 
buitendienst van dit gesticht. Het doel was om geestelijk abnormalen die daartoe in staat waren, buiten de inrichting, in Rotterdam zelf, te verzorgen. Hierdoor konden gestichtsplaatsingen worden voorkomen of in tijdsduur bekort. ${ }^{341}$ In de eerste maanden van 1926 konden met behulp van de buitendienst in totaal 72 patiënten met succes vanuit Maasoord naar Rotterdam worden teruggeplaatst. ${ }^{342}$

Meijers had lang niet zoveel succes als zijn Rotterdamse collega. Het aantal gestichtsopnames bleef in de loop van de jaren twintig stijgen. Daarom benoemde B\&W in 1926 een commissie, onder voorzitterschap van de directeur van de GG\&GD, L. Heijermans. Zij moest de oorzaken van de stijging van de uitgaven aan de verpleging van zenuwzieken, krankzinnigen en maatschappelijk ongeschikten onderzoeken. ${ }^{343}$ De conclusie was dat Meijers niet voldoende tijd besteedde aan de controles voorafgaand aan een opname. Daarom kreeg hij er in 1931 een collega bij, de psychiater A. Querido, die hem in 1933 bij zijn pensionering zou opvolgen. ${ }^{344}$

\subsubsection{Arbeidsvoorziening en zwakzinnigheid}

Aan het begin van de twintigste eeuw waren in enkele steden in Nederland Arbeidsbeurzen opgericht, waar vraag en aanbod op de arbeidsmarkt op elkaar afgestemd zouden moeten worden. In Amsterdam was vanaf 1913 W.F. Detiger directeur van de gemeentelijke arbeidsbeurs. Hij was een van de eersten die zich vanuit het gezichtspunt van de arbeidsbemiddeling bezighield met mensen die vanwege een gebrek verminderde toegang tot de arbeidsmarkt hadden. In 1920 introduceerde hij de term maatschappelijk mindergeschikten om deze groep aan te duiden. Hij omschreef deze groep als:

"... degenen die uithoofde van lichaams-, geestes of zielsgebreken niet ten volle mede kunnen concurreeren op de arbeidsmarkt. De felle wedstrijd op die markt tusschen de volkomen valiede werkkrachten brengt van zelfsprekend hen, die niet voor honderd procent geschikt zijn achterop." 345

Ook zwakzinnigen behoorden tot de maatschappelijk mindergeschikten. Door deze term te introduceren kon Detiger een onderscheid maken tussen degenen die niet konden werken en degenen die dat niet wilden. Het was nadrukkelijk zijn bedoeling, maatschappelijk mindergeschikten een betere behandeling te geven dan de werkonwilligen.

"Thans is de maatschappelijk mindergeschikte overgeleverd aan armenzorg en liefdadigheid en staat in hetzelfde gelid als de arbeidsschuwe, de dronkaard, de arbeidsonwillige, de vagebond. Hij staat op éen lijn met de werkelijke paria's. En voor zoover hij door de zorg van een of ander particuliere organisatie apart wordt gesteund draagt die steun voor hem het karakter van een liefdadigheid en is die steun maar al te vaak onvoldoende. ${ }^{.346}$

Detiger wilde dat de arbeidsbeurzen zich ook op deze groep zouden richten om voor hen passend werk te vinden. Hij vond dat iedereen die wilde werken daartoe ook de gelegenheid behoorde te krijgen.

"Ten slotte (...) eischt de positie van den maatschappelijk mindergeschikte als lid der arbeidende gemeenschap, zijn plaats op de arbeidsmarkt de afzonderlijke aandacht, zoonoodig een opzettelijke verzorging. Voorop sta, dat de maatschap- 
pelijk mindergeschikten recht hebben op belangstelling en steun der gemeenschap, omdat ook hun werkloosheid aan maatschappelijke oorzaken is toe te schrijven." 347

Nederland liep hierin ten opzichte van de omliggende landen achter. Dat had te maken met de neutraliteit van ons land tijdens de Eerste Wereldoorlog. Hierdoor hadden we hier niet te maken met grote aantallen oorlogsinvaliden die in vredestijd weer aan het werk geholpen moesten worden. In vrijwel alle omringende landen werden bedrijven bijvoorbeeld verplicht om een bepaald percentage oorlogsinvaliden in dienst te hebben. In Duitsland bestond die verplichting ook voor blinden en slachtoffers van arbeidsongevallen. ${ }^{348}$

Om ook in Nederland een begin te maken met de hulp aan maatschappelijk mindergeschikten, begon de Amsterdamse arbeidsbeurs in 1925 een afdeling $B i j$ zondere Bemiddeling. Deze stelde zich ten dienste van

"...personen, die tengevolge van psychische gebreken of van andere omstandigheden niet als volkomen valide arbeidskrachten beschouwd kunnen worden." ${ }^{349}$

Er werd in 1927 een ambtenares aangesteld die nauw samenwerkte met de GG \& GD voor vooral psychotechnisch en medisch onderzoek. ${ }^{350}$ Een apart onderdeel van deze afdeling hield zich bezig met jongeren onder 18 jaar en richtte zich ook op zwakzinnigen. Daarmee kwam de arbeidsbeurs in het vaarwater van de nazorg van De Boer. Dat zal waarschijnlijk ook de reden zijn geweest dat deze afdeling onder direct toezicht van Detiger stond. In de praktijk viel het met de concurrentie tussen deze twee gemeentelijke diensten erg mee. Het zwaartepunt van de afdeling Bijzondere Bemiddeling lag bij cliënten met een lichamelijke problematiek. ${ }^{351}$ In 1930 zou ook de Haagse gemeentelijke arbeidsbeurs met een afdeling voor bijzondere bemiddeling beginnen. ${ }^{352}$

In 1927 stond Detiger mede aan de wieg van de Nederlandsche Vereeniging tot Bevordering van den Arbeid voor Onvolwaardige Arbeidskrachten (AVO), die ernaar streefde overal in het land voor onvolwaardige arbeidskrachten, zoals maatschappelijk mindergeschikten inmiddels werden genoemd, passend werk te scheppen. ${ }^{353}$ Uitdrukkelijk doel was al bestaande of nog te vormen initiatieven op dit gebied, te bundelen en onder één vlag te brengen:

\begin{abstract}
"Centrale organisatie schept de mogelijkheid, de technische en commercieele leiding aan betere krachten op te dragen, de outillage der werkplaatsen aan hoogere eischen te doen beantwoorden, en tenslotte de organisatie van produktie en afzet meer rendabel te maken, omdat het aantal beschikbare arbeidskrachten grooter is en de verschillende typen van beperkt-arbeidsgeschikten elkaar in hun werk kunnen aanvullen. ${ }^{.354}$
\end{abstract}

De AVO had voor wat betreft de nazorg voor oud-leerlingen van het BLO vooral belangstelling voor de werkinrichtingen. Die beschouwde zij als een onderdeel van haar werkveld. De AVO zou deze graag onder haar invloedssfeer brengen, temeer omdat de werkinrichtingen voor zwakzinnigen een substantieel deel uitmaakten van alle werkinrichtingen voor onvolwaardigen samen: in 1929 waren er in totaal 20 van deze werkinrichtingen, waarvan 6 voor zwakzinnigen. ${ }^{355}$

Eén van de eerste activiteiten van de AVO was het organiseren van een 
groots opgezet congres, dat in 1928 werd gehouden. Vrijwel alle deskundigen op het gebied van de zorg voor mensen met een gebrek in Nederland en enkelen uit het buitenland werden hier bij elkaar gebracht - met uitzondering van het BLO, dat daarover zeer verbolgen was ${ }^{356}$. Op het meerdaagse congres werden tientallen inleidingen gegeven over uiteenlopende onderwerpen als sociale wetgeving, gehandicaptenzorg en aangepaste arbeid, met daarna gelegenheid tot discussie. Zowel De Boer als Wepster verzorgden zo'n inleiding. Het congres, met daaraan gekoppeld een tentoonstelling in het Stedelijk Museum, werd geopend door prins Hendrik en kreeg veel aandacht in de pers. Het zorgde ervoor dat de speciale arbeidsvoorziening voor mensen met een gebrek brede maatschappelijke aandacht kreeg en het onderwerp op de politieke agenda geplaatst werd. In het hele land werden afdelingen van de AVO opgericht en de regering besloot een staatscommissie in te stellen, die tot taak kreeg het vraagstuk van de onvolwaardige arbeidskrachten te bestuderen en met adviezen te komen voor landelijk beleid op dit gebied. De commissie zou ruim de tijd nemen en pas tien jaar later met haar eindrapport komen. ${ }^{357}$

In het kader van de geschiedenis van de nazorg was de terminologie zoals de AVO die hanteerde van belang. Men sprak er over onvolwaardige arbeidskrachten, waarmee duidelijk werd gemaakt dat het om mensen ging die problemen hadden op de arbeidsmarkt. Het begrip werd echter al snel afgekort tot onvolwaardigen. Dat leidde tot verwarring, omdat met dit begrip mensen werden aangeduid die op allerlei sociaal en maatschappelijk gebied problemen hadden en niet alleen op de arbeidsmarkt beperkt in hun mogelijkheden waren.

Binnen het begrip onvolwaardigheid zoals de AVO dat hanteerde, werd een onderscheid gemaakt tussen lichamelijk en geestelijk onvolwaardigen, waarbij geestelijke onvolwaardigheid als een groter probleem werd beschouwd dan de lichamelijke .

"De beteekenis van den arbeidenden mensch wordt bepaald door geest en lichaam. Wat aan het lichamelijke te kort komt, kan door den geest meer dan vergoed worden. De geest dwingt het lichaam tot gehoorzaamheid. Waar de geest defect is, kan een volwaardig lichaam dat defect niet vergoeden. ${ }^{\text {.358 }}$

Zwakzinnigen werden beschouwd als geestelijk onvolwaardigen zoals ook psychopathen en krankzinnigen.

\subsubsection{Nazorg of internaatszorg}

Aan het einde van de jaren twintig raakten nazorg en de kleinschalige residentiële zwakzinnigenzorg met elkaar in discussie. Dat gebeurde zowel schriftelijk in enkele vaktijdschriften als mondeling op een tweetal congressen. In deze discussies stond de vraag centraal, waar zwakzinnigen het beste konden worden ondergebracht: in de vrije maatschappij of in de beschermende omgeving van een gesticht of internaat.

De zelfstandige residentiële zwakzinnigenzorg was in deze periode nog relatief jong: pas dertig jaar tevoren, in 1891, was het eerste geneeskundig gesticht voor idioten geopend, het protestants-christelijke 's-Heeren Loo in Ermelo. Tevoren warem zwakzinnigen die niet zelfstandig konden wonen vooral in krankzinnigengestichten ondergebracht. In 1900 werden de eerste zwakzinnigeninternaten 
gesticht, Wilhelmina in Zeist en Heimerstein in Rhenen, in 1905 gevolgd door Klein Warnsborn in Arnhem. Later zouden er nog enkele andere internaten volgen. Er werden alleen kinderen verpleegd die in staat waren een vorm van (BLO-) onderwijs te volgen. De meesten van hen waren afkomstig uit de betere standen, omdat de verpleegprijzen voor de meeste gemeenten te hoog waren. De ouders betaalden deze in de meeste gevallen zelf. ${ }^{359}$ Internaten als het katholieke Huize Assisië in Udenhout, in 1904 opgericht en het protestants-christelijke Groot Emaus in Ermelo, dat uit 1907 stamde, waren grootschaliger en konden daardoor lagere verpleegprijzen in rekening brengen. Daardoor kregen zij veel kinderen uit de lagere sociale milieus binnen, die er op kosten van de gemeente verpleegd werden. Vooral voor deze instellingen betekende de nazorg concurrentie, maar gek genoeg namen betrokkenen uit deze instellingen geen deel aan de discussie met de nazorg.

De meest extreme mening over de plaats van zwakzinnigen in de samenleving werd in 1926 geventileerd in het Tijdschrift voor RKBLO. Hier stelde een anonieme schrijver, aangeduid met de initialen H.E., dat het BLO een gevaarlijk experiment was. Zwakzinnigen vormden volgens hem een gevaar voor de samenleving, of ze nu op school hadden gezeten of niet. Hij vond het 't veiligste als ze in werkkolonies op het platteland zouden worden ondergebracht. ${ }^{360} \mathrm{Hij}$ haalde niet nader aangeduide Duitse cijfers aan waaruit zou blijken dat $60 \%$ van de debielen na het verlaten van de Hilfsschule maatschappelijk mislukte. Verder stelde hij dat de zwakzinnigheid van 60 tot $70 \%$ van de debielen terug te voeren was op 'erfelijke zenuwziekte der ouders'. ${ }^{361} \mathrm{Hij}$ stelde, dat deze ouders niet in staat waren hun kinderen fatsoenlijk op te voeden. ${ }^{362}$ Daarom vond hij dat de overheid het recht moest krijgen om deze kinderen bij hun ouders weg te halen. Ze moesten dan een gestichtsopvoeding krijgen, die in zijn ogen kwalitatief beter was dan opvoeding in het eigen gezin.
"Als de ouders in hun dwaze liefde (egoïsme, tijdelijk voordeel of natuurlijk ge- noegen, in 't bezit van kinderen gelegen) met hun debiele hersenen niet inzien, dat 't noodzakelijk is voor 't geluk van 't kind, dan heeft de overheid het recht en den plicht in 't belang der maatschappij, die ouders te dwingen hun kind voor ' $n$ tijd af te staan. ${ }^{363}$

Binnen het confessionele BLO werd fel op de standpunten van H.E. gereageerd. Men vond, dat deze de gunstige invloed van het BLO op zwakzinnige kinderen té zeer onderschatte. ${ }^{364}$ A.J. Calliber, christelijk schoolhoofd uit Amsterdam, was het oneens met de stelling van H.E. dat gestichtsopvoeding te prefereren was boven een opvoeding in het gezin. Hij vond dat elk kind er recht op had om in het eigen gezin, bij de eigen ouders, op te groeien. ${ }^{365}$ Th. Willemsen, hoofd van de R.K. school voor BLO in Rotterdam, deelde die mening en ging nog een stapje verder: de overheid diende volgens hem uiterst terughoudend te zijn bij het ingrijpen in een opvoedingssituatie:

"Of deze (de ouders van een zwakzinnige, LB) bemiddeld zijn of arm - intelligent of dom - godsdienstig practiseerend of niet - paedagogisch bekwaam of ondeskundig, doet allemaal voor ons niet ter zake: zoolang er geen sprake van is, dat zij hun kinderen verwaarloozen, heeft niemand het recht ze hen te ontnemen. ${ }^{366}$ 
Op twee achtereenvolgende congressen, het Paedagogisch Congres van 1926 en het AVO-congres van 1928, beide in Amsterdam, gingen vertegenwoordigers van de nazorg en de kleinschalige residentiële zwakzinnigenzorg rechtstreeks met elkaar in debat.

Op het Paedagogisch Congres van 1926 hield Pier de Boer een lezing onder de titel Nazorg voor het Abnormale Kind ${ }^{367}$. Hierin zette hij onder andere zijn visie op gestichtsverzorging van zwakzinnigen uiteen. Hij vond deze alleen verantwoord als opname een therapeutisch belang had. Het moest in zijn opvatting dienen om een gedragsverandering tot stand te brengen en diende een beperkte periode te duren.

"Gestichtsverzorging vonden wij nergens als doel verdedigd. Wel als middel; en dan zouden wij kunnen aangeven, dat gestichtsverzorging wordt opgelegd, om den abnormale na en door een bijzondere verzorging het leven in een gewoon milieu weer mogelijk te maken, of, wat hetzelfde is, den normale mogelijk te maken, den abnormale weer in zijn milieu toe te laten." ${ }^{368}$

De Boer vroeg zich af, of de Nederlandse gestichtsverzorging wel op dit doel was ingesteld. Hij meende van niet:

"Beantwoordt de gestichtsverzorging, zooals wij die hier kennen, aan de noodige eischen om hieraan te voldoen? Zal de abnormale door de gestichtsverzorging belangrijk verbeteren en is de kans, dat de normale de(n) abnormale in zijn milieu weer kan toelaten na eenigen tijd gestichtsverzorging vergroot? Voor een belangrijk aantal abnormalen is dit uiterst riskant. ${ }^{n 69}$

Hij stelde, dat het gesticht voor zwakzinnigen niet de meest geschikte plaats was om te leren leven in de maatschappij. Zijn stelling was:

" Niet door het gesticht, maar door het leven leeren wij." ${ }^{370}$

Hij wees erop, dat zwakzinnigen die de lagere school op een internaat bezochten, bij terugkeer in de maatschappij als ze meerderjarig waren geworden, een belangrijk nadeel hadden ten opzichte van hun leeftijdsgenoten die het onderwijs in de samenleving hadden gevolgd.

"Het mag voor de tegenwoordige jeugd normaal worden genoemd dat zij op 14-, 15- of 16-jarigen leeftijd in vrije aanraking komen met het sociale leven en daarin hare ervaringen opdoet. ledere moedwillige beperking van deze aanraking wreekt zich door mindere omgangsgeschiktheid, minstens door het scheppen van een moeilijke overgangsperiode." 371

"Hoe moet het dan zijn voor zwakzinnigen en andere abnormalen, waarover wij hier spreken. Zij zijn juist uit de maatschappij verwijderd, omdat zij niet tegen de moeilijkheden opgewassen waren, omdat zij niet tegen de verleiding bestand waren, omdat zij te weinig aanpassingsvermogen hadden. Is het redelijk te verwachten, dat zich in deze individuen een tegenwicht vormt, als zij niet dagelijks de moeilijkheden ervaren? En is het te verdedigen, deze abnormalen na eenige (soms vele) jaren gestichtsverzorging zoo'n kans met zooveel risico's te geven om in het leven te slagen of terug te vallen? ${ }^{\text {n372 }}$

Samengevat stelde De Boer, dat gestichtsopvoeding voor zwakzinnigen te enen male ongeschikt was: 
"Gestichtsverzorging belemmert den omgang met 'het leven'. Juist voor de groote bevolkingscentra is het vraagstuk der abnormalenverzorging klemmend, maar tee-kent zich de tegenstelling tusschen de gestichtsverzorging en de toch als doel gestelde latere vrije verzorging scherp af. Omgang en verhoudingen in gesticht en het gewone leven verschillen zeer..." ${ }^{373}$

Een ander bezwaar dat De Boer tegen gestichtsverzorging had, was dat er doorgaans pas toe werd overgegaan als er al veel in het leven van het betrokken kind was misgegaan, waardoor het aanzienlijk moeilijker werd om goed te kunnen helpen.

Gestichtsverzorging is een zeer ingrijpende maatregel, in den regel zal er mee worden gewacht, tot de noodzakelijkheid van verwijdering uit de maatschappij duidelijk spreekt en dus worden pas maatregelen genomen, als in den regel veel kostbare tijd is verloren gegaan. ${ }^{374}$

De vertegenwoordigers van de kleinschalige residentiële zwakzinnigenzorg waren het, zoals te verwachten viel, niet eens met deze opvattingen. $\mathrm{Zij}$ voerden niet het bezwaar aan dat zwakzinnigen een gevaar vormden voor de samenleving, zoals H.E. dat in het Tijdschrift voor RKBLO had gedaan. Zij legden er de nadruk op, dat het in het belang van zwakzinnigen zélf was om in een beschermende omgeving te worden ondergebracht. De heer André, directeur van zwakzinnigeninternaat Heimerstein in Rheden, ${ }^{375}$ verweet in de discussie die op deze lezing volgde De Boer dat hij geen rekening hield met het wezen van de zwakzinnige:

"M.i. legt hij er niet genoeg den nadruk op, dat het verstandelijk minderwaardig zijn, het minder goed kunnen leeren, minder vlug iets begrijpen slechts één uiting der zwakzinnigheid is. Het verstandelijk defect is een uiting van het geheele defecte wezen der zwakzinnigen. Een zwakzinnige is niet een normale op verkleinde schaal, maar in zijn wezen anders dan de normale., ${ }^{376}$

Volgens André richtte de samenleving zich alleen op de normalen. Daardoor werd het voor zwakzinnigen steeds moeilijker om zich in de samenleving te handhaven. Het was daarom in hun belang, hen tegen die samenleving in bescherming te nemen:

"De maatschappij is ingesteld op het normale, en hoe meer de maatschappelijke verhoudingen zich toespitsen, hoe meer de maatschappij het abnormale zal uitstooten. (...) Niet als doel voorop stellen, dat de zwakzinnige een plaats in een hem vijandige, afwerende en afstootende maatschappij moet innemen (...) M.I. moet voor die zwakzinnigen een maatschappij gevormd worden, die voor hen en op hen ingericht is, internaten of kolonies, waar ieder zijn plaats en voor hem geschikt werk heeft." ${ }^{377}$

De Boer was het hiermee niet eens. Hij stelde, dat instellingen als BLO en nazorg aantoonden, dat er in de maatschappij juist een tegengestelde beweging was waar te nemen, die het voor zwakzinnigen mogelijk makkte om in de samenleving te blijven functioneren.

"Onjuist acht ik de stelling, dat, hoe meer zich de maatschappelijke verhoudingen toespitsen, hoe meer de maatschappij de abnormale zal uitstooten. Integendeel; wij zien juist in de maatschappij de organen ontstaan, die moeten dienen, 
om dat, wat dreigt onder te gaan, te beschermen en te verzorgen, ook als het afwijkt van het normale." ${ }^{378}$

Twee jaar later, tijdens het AVO-congres van 1928, deden vertegenwoordigers van de zwakzinnigeninternaten een poging om de discussie voort te zetten. Ook hier hield De Boer een inleiding onder de titel De zorg voor Achterlijken naar hun Opleiding. ${ }^{379} \mathrm{Hij}$ sprak vooral over de werkwijze van de nazorgambtenaar. Zijn bezwaren tegen gestichtsopvoeding waren sinds 1926 niet wezenlijk veranderd.

"Geplaatst en opgeleid in een internaat missen zij de practische aanraking met het sociale milieu, waarin zij zich later moeten aanpassen. ${ }^{380}$

André, die opnieuw aanwezig was, vond inmiddels dat niet langer álle zwakzinnigen in een gesticht of internaat moesten worden ondergebracht, maar alleen diegenen die niet in staat waren om arbeid in loondienst te verrichten.

" $\mathrm{Er}$ is dus een aantal zwakzinnigen, die voor loondienst weinig of niet geschikt zijn, die altijd groote moeilijkheden in de maatschappij zullen geven, die door hun geheel defecte wezen in de maatschappij geen plaats kunnen vinden. Spreker ziet voor hen slechts één weg. Schept voor hen een kleine maatschappij waarin zij passen." 381

Hij gebruikte een nieuw argument dat vóór gestichtsverzorging pleitte. Hij stelde dat in gestichten de arbeidsproductiviteit tot grote hoogte kon worden opgestuwd, hoger dan in de vrije maatschappij. ${ }^{382} \mathrm{~J}$. Denneboom, directeur van zwakzinnigeninternaat S.S. Rudelsheimstichting in Hilversum, was het hiermee eens en gaf aan, hoe de praktijk er op zijn internaat uitzag:

"Arbeidsgeschiktheid toch kan in gestichten zeer hoog opgevoerd worden. De kinderen kunnen den geheelen dag bezig gehouden worden (...). Speciaal kunnen de meisjes ingewijd en voortdurend geoefend worden in alle huishoudelijke bezigheden. Zelfs kleine jongens werken buiten de schooluren in tuin en bosch; groote jongens hebben bovendien een volledige werkplaats met werkbanken en gereedschap te hunner beschikking. In welk gezin treft men dat aan? Onze ondervinding is, dat onze verpleegden steeds arbeiden en dat zelfs in hun speeltijd doen. Het internaat geeft een groote mate van arbeidsgeschiktheid. ${ }^{383}$

Hij bestreed de stelling van De Boer, dat zwakzinnigen in internaten té weinig contact hadden met de hen omringende maatschappij:

"Aanpassingsvermogen wordt evenzeer verkregen en is ook vooral in kleine inrichtingen in groote plattelandsgemeenten gemakkelijk in de hand te werken. Wanneer de verpleegden dadelijk na het verlaten der internaatsschool geplaatst worden in particuliere werkplaatsen en er voldoende contact tusschen patroon en internaatsleiders is, kan een goede opleiding verkregen worden in nauw contact met de maatschappij. ${ }^{384}$

Denneboom stelde, dat opvoeding in een internaat beter was dan het BLO, omdat alleen in een internaat de gehele dagbesteding van zwakzinnigen kon worden gecontroleerd. Op het BLO kon dat alleen maar tijdens de lesuren.

"Meerdere Hoofden van Buitengewone Scholen hebben bij een bezoek aan ons internaat tot mij gezegd: 'Ik benijd U: aan onzen arbeid wordt zooveel verknoeid door het milieu, waarin onze leerlingen buiten de school verkeeren: Uw werk ondervindt die nadeelen niet. Heerlijke samenwerking tusschen school- en inter- 
naatspersoneel, hoe mooi wordt die verkregen en welke vruchten werpt zij af! Veel onzer verpleegden zouden thans reeds lang in een Rijksopvoedingsgesticht geplaatst zijn, als zij niet bij ons waren en wat zou er dan van het aanpassingsvermogen terecht zijn gekomen? ${ }^{385}$

De Boer reageerde amper op deze nieuwe argumenten van de voorstanders van gestichtsverzorging voor zwakzinnigen. Hij voegde alleen Denneboom toe, dat hij internaatsverzorging van jonge kinderen niet alleen afwees vanwege de problemen die ze bij terugkeer in huiselijk milieu ondervonden, maar ook en vooral vanwege de moeilijkheden die ze kregen met hun directe sociale omgeving buiten het gezin. $^{386}$

Nazorg en internaatswezen zouden het niet eens worden, daarvoor liepen hun belangen en hun houding ten opzichte van zwakzinnigheid té ver uiteen. Aan het einde van de jaren twintig verloor de discussie haar scherpte, om vervolgens geheel uit te doven. Op inhoudelijk gebied kwam men elkaar na 1928 niet meer tegen. Internaatswezen en nazorg functioneerden in vrijwel geheel gescheiden circuits, met eigen organisaties en tijdschriften. Van een uitwisseling van ideeën was er hierdoor geen sprake meer. Ook in de praktijk had men weinig met elkaar te maken. Elke hulpvorm had zo zijn eigen doelgroep. De zwakzinnigeninternaten hadden vooral te maken met kinderen uit de betere sociale klassen, nazorgwerkers met kinderen uit de lagere sociale klassen, voor wie een verblijf in de duurdere zwakzinnigeninternaten niet was weggelegd. Nazorg en internaatswezen bleken in hun praktijk elkaar amper concurrentie aan te doen. Zwakzinnigengestichten en nazorg hadden veel meer met elkaar te maken, maar hadden beide belang bij een goede relatie. Nazorgwerkers waren, ondanks de concurrentie die zij de gestichten aandeden, de belangrijkste plaatsers van zwakzinnigen in de gestichten. En zij wilden de relatie met de gestichten goed houden om bewoners die daarvoor in aanmerking kwamen in de maatschappij te kunnen terugplaatsen. ${ }^{387}$

\subsection{Theorie van de nazorg}

Het is enigszins gewaagd om te spreken over de 'theorie van de nazorg', want als er één ding was, waaraan de nazorgwerkers een hekel hadden dan was het getheoretiseer. Aan de discussies over de aard van zwakzinnigheid en de wijze waarop de zwakzinnigenzorg idealiter zou moeten worden ingericht, namen zij amper deel. De discussie over internaatszorg of nazorg uit de vorige paragraaf was de enige inhoudelijke discussie waaraan, voor zover ik kon nagaan, nazorgwerkers actief deelnamen. Alleen als de praktijk van de nazorg aan bod kwam, mengden de nazorgwerkers zich in het debat. Dat was in vrijwel alle gevallen Pier de Boer, die in deze periode de vruchtbaarste auteur was op het gebied van de nazorg. Hij legde altijd de nadruk op het belang van kennis van de praktijk. Voor hem was ervaringskennis in het werken met oud-leerlingen van het BLO het belangrijkste onderscheidende kenmerk ten opzichte van andere hulpvormen, zoals de psychiatrie en de arbeidsbemiddeling.

Toch hadden nazorgwerkers, zoals uit de vorige paragraaf blijkt, een onderliggende visie op zwakzinnigheid die bepalend was voor hun handelen. De nazorg gebruikte, voortkomend uit die onderliggende visie, een aantal verschillende classificatiewijzen van zwakzinnigen en zwakzinnigheid die van belang waren voor 
de praktijk van het nazorgwerk.

Allereerst deelden nazorgwerkers de algemene overtuiging die binnen het BLO heerste, dat zwakzinnigen een risico vormden en daarom in de maatschappij begeleiding nodig hadden om niet tot een last voor de samenleving te vervallen.

"De Nazorg heeft tot doel, de leerlingen, die de school voor Buitengewoon Onderwijs verlaten hebben en die dus niet meer dagelijks onder de paedagogische leiding van hun onderwijzers staan, in hun moeilijken strijd om het bestaan te helpen en ze voor te lichten. Wordt hun deze hulp niet geboden, dan zullen velen van hen na tallooze teleurstellingen, mislukken en ten laste der samenleving komen, omdat ze dan als maatschappelijk ongeschikten in gestichten moeten worden opgenomen. Met voldoende steun en voorlichting zal het mogelijk blijken, dat ongeveer $75 \%$ zich een geheel of gedeeltelijk zelfstandig bestaan in de maatschappij verovert. ${ }^{388}$

De definitie van zwakzinnigheid die nazorgwerkers hanteerden waren dezelfde als die in het BLO gebruikelijk waren. Op dit punt bestond er geen enkel verschil van mening en de omschrijving van Herderschêe werd zonder meer overgenomen. Net als in het BLO beschouwden ook de nazorgwerkers de test van Binet en Simon, in de bewerking van Herderschêe, als de belangrijkste maatstaf om te bepalen of een kind al dan niet zwakzinnig was. Dat leidde er toe, dat in de opvatting van de nazorgwerkers ál hun pupillen zwakzinnig waren, anders zouden ze niet op het BLO terecht zijn gekomen.

Volgens nazorgwerkers verschilden zwakzinnigen niet wezenlijk van normale mensen, zoals wel in kringen van de zwakzinnigeninternaten werd beweerd. $\mathrm{Zij}$ hadden dezelfde wensen en verlangens en mochten daarom niet zondermeer in internaten worden ondergebracht, zoals De Boer in 1926 stelde:

"De zwakzinnige waardeert den vrijen omgang in de maatschappij even goed als de normale; hij waardeert ook zijn 'milieu', in den ruimsten zin genomen, en verlangt even goed als de normale naar zijn 'thuis'. Alleen uit hij het op een afwijkende manier." ${ }^{389}$

Deze opvatting betekende niet, dat nazorgwerkers er vanuit gingen dat zwakzinnigen zich als normale mensen gedroegen. Hun zwakzinnigheid, die volgens de meeste nazorgwerkers veroorzaakt werd door erfelijke aanleg, leidde tot problemen op sociaal gebied. Hierdoor liepen zwakzinnigen het risico om, bij het ontbreken van adequate begeleiding, te ontsporen. Vooral De Boer heeft zich nadrukkelijk beziggehouden met het in kaart brengen van deze sociale problematiek. Centraal in De Boers opvatting stonden de gebrekkige doel- en gevolgvoorstellingen van zwakzinnigen, waardoor hun oordeelsvermogen zou zijn aangetast.

"De doel- en gevolgvoorstellingen zijn of niet, of in geringe mate aanwezig om aan het denken inhoud te geven. Zij denken daardoor vaak verkeerd, oordeelen vaak verkeerd door hun gebrekkig inzicht over de verhoudingen, waarin zij geplaatst zijn. ${ }^{3}{ }^{390}$

Dit gebrekkige oordeelsvermogen kon bij zwakzinnigen leiden tot karakter-en omgangsfouten, die hun sociale functioneren ernstig konden verstoren. De Boer onderscheidde hierin drie hoofdvormen, te weten een egocentrische aanleg, het 
ontbreken van vooroverweging en verhoogde suggestibiliteit. ${ }^{391}$ Elk van deze drie karakter- en omgangsfouten droegen ertoe bij, dat zwakzinnigen dissociaal waren, een term die De Boer van Klootsema had overgenomen. ${ }^{392}$

Gevolg van de egocentrische aanleg was, dat zwakzinnigen een slecht inzicht hadden in sociale verhoudingen. Ze hadden volgens De Boer de neiging om hun eigen rol en aandeel daarin te overschatten, waardoor ze in conflict met hun omgeving konden komen.

"Thuis komen conflicten voor, omdat zij zich achtergesteld voelen bij andere huisgenooten. Oppervlakkig en scheef zien zij, omdat zij een zeer onvolledig beeld hebben van het geheel, hun bescheiden aandeel in het bedrij; zien zij niet in, waarom precies de voorgeschreven werkmethode gevolgd moet worden, vóór het ongeval er is. ${ }^{\text {.393 }}$

Het ontbreken van vooroverweging leidde tot impulsief handelen zonder van tevoren na te denken over de gevolgen ervan. Ook dit kon volgens De Boer ernstige gevolgen hebben:

"Zij zijn vaak impulsief, handelen in hun eerste opwelling, zonder verder na te denken. Voor een deel zal ook dit het gevolg zijn van de gebrekkige voorstellingen, die de ervaring van vroegere feiten heeft achtergelaten en door gebrekkige associatie.."394

De verhoogde suggestibiliteit ten slotte hield volgens De Boer in, dat zwakzinnigen makkelijk van alles wijs te maken was. Ze waren daardoor door mensen met kwade bedoelingen tot allerlei handelingen over te halen. Hierdoor konden zwakzinnigen in ernstige problemen geraken:

"Sterke suggestibiliteit maakt den imbecil vaak tot een willoos werktuig in handen van anderen. Voor vele voor loondienst geschikte zwakzinnigen is deze eigenaardigheid vaak een bron van leed, omdat meermalen normale werkkrachten niet kunnen laten deze stumpers er 'tusschen' te nemen, door hen alle mogelijke of liever onmogelijke dingen wijs te maken." ${ }^{395}$

Deze drie karakter- en omgangsfouten hadden volgens De Boer tot gevolg, dat zwakzinnigen vaak een onvoldoend aanpassingsvermogen aan hun sociale omgeving hadden, waardoor ze zwakker in het leven stonden dan normale mensen.

"Zij moeten het leven in en het leven door zonder (sterk ontwikkeld) verantwoordelijkheidsgevoel, met geringen aanleg voor beroepsontwikkeling en dus steeds de mindere in den levensstrijd in vergelijking met den normale." ${ }^{396}$

Dit aspect van zwakzinnigheid was er de oorzaak van dat zwakzinnigen een risico voor de maatschappij vormden.

"Wat thuis niet gevonden wordt, zoeken ze buitenshuis en daar staat de z.z. jeugd aan velerlei gevaren bloot: straatschenderij, diefstal, drankmisbruik, prostitutie enz. Vaak worden z.z. door hun geringe weerstandsvermogen en hun groote suggestibiliteit door minderwaardige individuen misbruikt tot het volvoeren van hun wandaden. De z.z. loopen daarbij tegen de lamp en de opzetters van het misdrijf blijven buiten schot." ${ }^{397}$

De belangrijkste taak van de nazorg was volgens De Boer het beschermen van 
zwakzinnigen tegen deze aspecten van hun karakter en de risico's die er in de maatschappij voor hen bestonden zo veel mogelijk te beperken. Daarbij gold het volgende uitgangspunt:

"Voor de Nazorg zou het opschrift van deze bijdrage moeten zijn: Behoud van de z.z. in het huisgezin en daardoor in zijn sociaal milieu. ${ }^{398}$

Om dit belangrijkste doel van de nazorg te bereiken, hanteerden de nazorgwerkers verschillende classificaties van zwakzinnigheid tegelijkertijd, elk met een eigen specifiek doel in de dagelijkse praktijk van het nazorgwerk.

Allereerst was de mate van de verstandelijke beperktheid van belang. Hierbij gebruikte men de driedeling debiel - imbecil - idioot, waarvan ik de ontstaansgeschiedenis al in paragraaf 1.1 heb behandeld. Nazorgwerkers hadden alléén te maken met debielen en imbecillen. De nazorgpupillen die als debiel werden geclassificeerd werden in staat geacht tot het verrichten van eenvoudige arbeid in loondienst. Voor hen werd in vrijwel alle gevallen werk gezocht. Uitzondering hierop vormden degenen, die met aanvullende problematiek te maken hadden, zoals te weinig handigheid, een langzaam reactievermogen, ernstige aandachtsfouten, lichamelijke afwijkingen en ernstige karakter-en omgangsfouten. Zij kwamen in aanmerking voor een plaats op de werkinrichting. ${ }^{399}$ Imbecillen, degenen die op een bezinkingsklas of speciale imbecillenschool hadden gezeten, werden door hun matig verstandelijke gebrek niet in staat geacht in loondienst te werken. $\mathrm{Zij}$ werden in principe allemaal op de werkinrichting geplaatst. ${ }^{400}$

Een andere classificatie van zwakzinnigen was overgenomen van de Duitse psychiater Scholz, die in zijn Anomale Kinder (1922)een onderscheid had gemaakt tussen apathische (passieve) en eretische (drukke) zwakzinnigen. ${ }^{401}$ Apathische zwakzinnigen hadden een gelijkmatige stemming en leverden daardoor weinig problemen op:

"Zonder eenigen twijfel levert de apatische zwakzinnige in huisgezin en maatschappij den minsten last. Het is het type, dat alle ervaringen kan ondergaan zonder te veranderen, dat onaandoenlijk voortgaat of niet voortgaat met hem opgedragen werk, al naar zijn gedisponeerdheid met zich meebrengt... ${ }^{402}$

Eretische zwakzinnigen echter konden door hun wisselende stemmingen en drukke gedrag wél problemen geven. $\mathrm{Zij}$ liepen een groter risico in de maatschappij dan de apathische zwakzinnigen.

"... de onrustige zwakzinnigen, die zich op school doen kennen als beweeglijk, ongedurig, vol bewegingsdrang. En ook al brengt de zelfbeheersching in den loop der jaren eenige verbetering vooral in de lichamelijke ongedurigheid, de geestelijke ongedurigheid blijft een groot struikelblok voor hen." ${ }^{403}$

Aan hun verzorging moest extra aandacht worden besteed. Zo moesten zij volgens De Boer bij voorkeur niet in grote, onoverzichtelijke arbeidssituaties worden geplaatst. Fabrieksarbeid werd voor hen niet geschikt geacht.

"De eretische debiel hoort in een fabriek of werkplaats met een groot personeel niet thuis, omdat hij dan bijna doorloopend moeilijkheden oplevert." ${ }^{404}$ 
Dit extra risico betekende niet, dat ze niet in de maatschappij konden worden geplaatst. Voorwaarde was wél, dat zij intensief werden begeleid.

De belangrijkste classificatiewijze die nazorgwerkers gebruikten was gekoppeld aan de verschillende vormen van problematiek die zij bij hun pupillen onderscheidden en was direct gerelateerd aan hun arbeidsgeschiktheid De eerste aanzet hiertoe had De Boer al gegeven in zijn eerste twee praktijkjaren in Amsterdam (zie paragraaf 2.3) en was door hem verder uitgewerkt in het Haarlems nazorgrapport van 1924:

"In Groep A. uit hoofde van: bijna geheele arbeidsongeschiktheid.

In Groep B. uit hoofde van: belangrijk verminderde arbeidsongeschiktheid.

In Groep C. uit hoofde van: het milieu.

In Groep D. uit hoofde van: karakter en gedragsfouten.

In Groep E. uit hoofde van: anti-sociale eigenschappen of aard der werkzaamheden." 405

J.J.C. van der Wouden, de Delftse nazorgwerker, bracht deze vijf categorieën in 1927 terug tot drie. Daarbij stelde hij de mate van bruikbaarheid voor de maatschappij centraal. Hij sprak over bruikbaren, minder bruikbaren en onbruikbaren. Het sociaal functioneren van de nazorgpupil stond in deze classificatie centraal. ${ }^{406}$
"De taak voor de maatschappelijk bruikbaren is niet zwaar. In het algemeen kun- nen deze zich zonder hulp handhaven.
De groep maatschappelijk minder bruikbaren vraagt (...) veel werk. Men wil met deze patiënten - door het aanwijzen en plaatsen in een gewenschten werkkring, het bijleggen van conflicten, het wegnemen van moeilijkheden in hun omgeving, het remmen der ongebreidelde gevoelens in hun puberteitsjaren, het geven van leiding bij hun moreele en godsdienstige opvoeding, enz. - een nauw contact zien te krijgen tusschen hen en de vereeniging.
De hier uiteengezette steun, hulp en leiding zullen voor de gemeenschap een fi- nancieel voordeel opleveren en zullen uit een moreel en materieel oogpunt van belang zijn voor de maatschappelijk minder bruikbaren." ${ }^{407}$

De Boer werkte deze driedeling in 1928 verder uit. Daarbij stelde hij de vraag centraal, in hoeverre nazorgpupillen in staat konden worden geacht om in hun levensonderhoud te voorzien.

"A. die (zwakzinnigen, LB), welke nooit in hun eigen onderhoud leeren voorzien; een gedeelte van hen is nog wel geschikt om in loondienst eenvoudig werk te verrichten (...).

B. van wie het twijfelachtig is, of zij geheel voor zichzelf leeren zorgen, maar die toch in ieder geval voor loondienst bruikbaar zijn, (...).

C. van wie vaststaat, dat zij in hun eigen onderhoud zullen leeren voorzien. Een gedeelte van hen gaat zonder groot onderscheid te maken met den normale door het leven. (....). ${ }^{.408}$

De mate van arbeidsgeschiktheid kwam in de loop van de jaren twintig steeds meer centraal te staan. Het werk van de nazorg richtte zich er vooral op, die geschiktheid zo groot mogelijk te maken. Daarbij werd de term arbeidsgeschiktheid gebruikt als synoniem van het veel bredere 'maatschappelijke geschiktheid'. Dat had te maken met de grote waarde die aan arbeid werd gehecht. Ten eerste konden oud-leerlingen 
zich door arbeid een materiële basis voor verblijf in de samenleving verwerven. Ten tweede had arbeid een zeer heilzame werking op oud-leerlingen van het BLO: het zou hen socialer maken en in deze zin hun verblijf in de maatschappij eveneens mogelijk maken. Zonder arbeid was er, in meerdere opzichten, alleen het perspectief van het gesticht. De nazorg was het in dit opzicht geheel eens met de opvatting van F.S. Meijers over het belang van arbeid voor geestelijk onvolwaardigen:

"Men begrijpt thans dat arbeid, een onmisbare levensvoorwaarde voor den geestelijk gezonde, den geestelijk zieke niet mag onthouden worden. ${ }^{409}$

\subsection{Praktijk van de nazorg}

\subsubsection{Groei van de nazorg}

$\mathrm{Na}$ het ontstaan van de nazorg in Amsterdam en Haarlem kwamen er tot $1930 \mathrm{nog}$ professionele nazorginstellingen bij in Vlaardingen, Delft, Utrecht, Arnhem en Breda terwijl er daarnaast werkinrichtingen voor oud-leerlingen van het BLO werden opgericht in Schiedam en Groningen. In Den Haag en Rotterdam kwam de invulling van de nazorg ter sprake, zonder dat er daadwerkelijk actie werd ondernomen.

In Arnhem en Vlaardingen werd een nazorgambtenaar in gemeentelijke dienst aangesteld, in Arnhem voltijds, in Vlaardingen in deeltijd. ${ }^{410}$ In Delft, Utrecht en Breda kwamen nazorgambtenaren in dienst van een particuliere organisatie. Dat was in al deze gevallen de ondersteuningsorganisatie van de plaatselijke school voor BLO. Deze organisaties ontvingen gemeentelijke subsidie voor het nazorgwerk. Alleen de Bredase nazorg wees uit principe overheidssubsidie af. Vergeleken met de toename van het aantal BLO-scholen, van 32 in 1922 tot 73 in 1929, bleef de nazorg met tien organisaties in 1929 hierbij vér achter.

In Vlaardingen werd al in 1919 de grondslag gelegd voor de nazorg, toen bij de opening van de openbare school voor BLO de vereniging Zorg voor het Achterlijke Kind werd opgericht.

"De vereeniging: Zorg voor het Achterlijke kind is gevestigd te Vlaardingen en stelt zich ten doel de belangen te behartigen van leerlingen en oud-leerlingen der buitengewone scholen voor lager onderwijs te Vlaardingen.

(...) Zij tracht dit doel te bereiken:

a. Door het verleenen van steun, raad en medewerking bij het kiezen van een beroep voor leerlingen van de buitengewone scholen voor lager onderwijs;

b. Door steunverleening bij het uitzenden van leerlingen naar een gezond heidskolonie;

c. Door in het algemeen op te treden in het belang der leerlingen en oudleerlingen van de scholen voor buitengewoon lager onderwijs. ${ }^{.411}$

Pas in 1923 werd het noodzakelijk die nazorg in de praktijk te brengen toen de eerste leerlingen de school voor BLO verlieten. ${ }^{412}$ Het toen pas benoemde schoolhoofd Herman Frantsen zette zich hiervoor in. Hij voerde het nazorgwerk uit en begon met het inzamelen van geld om een werkinrichting voor jongens te kunnen beginnen. Daarbij zocht en vond hij steun van onder andere het koninklijk huis en de vrijmetselarij. Ook organiseerde hij een loterij, met kostbare hoofdprijzen als een bouwkavel en een auto. ${ }^{413}$ Het benodigde geld kwam binnen en in 1926 ging de 
Vlaardingse werkinrichting van start. ${ }^{414}$ Twee jaar later, in 1928, kwam er een werkinrichting voor meisjes bij, ${ }^{415}$ de eerste in haar soort in Nederland. Ze werd weefkamer genoemd. ${ }^{416}$ Er werkten eerst 4 , later 6 meisjes. ${ }^{417}$ In 1928 werd Frantsen door de gemeente Vlaardingen aangesteld als Leider van de Nazorg, een functie die hij in deeltijd uitoefende naast dat van schoolhoofd. Zijn salaris bedroeg fl. 1000 ,- ( $€ 455,-)$ per jaar. ${ }^{418}$ In oktober van dat jaar ging het avondonderwijs van start, eveneens onder verantwoordelijkheid van Frantsen. ${ }^{419}$

In Delft ontstond de nazorg door een initiatief van J.J.C. van der Wouden, onderwijzer aan het BLO en Ambtenaar voor de Kinderwetten van de vereniging Pro Juventute, een kinderbeschermingsinstelling die zich richtte op kinderen die met politie en justitie in aanraking waren geweest. Hij had een Rapport inzake de nazorg voor zwakzinnigen en lichamelijk gebrekkigen geschreven, dat niet bewaard is gebleven. Het vormde de aanleiding voor een groep notabelen, waaronder de gemeentesecretaris en de wethouder van onderwijs, om een comité op te richten dat zich ten doel stelde om in Delft een nazorginstelling op te richten.

Van der Wouden werd secretaris van dit nazorgcomité, dat onder voorzitterschap van de wethouder stond. In het bestuur waren onder andere een dominee en een pastoor opgenomen, om duidelijk te maken dat het de bedoeling was om BLO-leerlingen van alle gezindten te bedienen. ${ }^{420}$ De activiteiten van het nazorgcomité leidden op 12 oktober 1926 tot de oprichting van de Vereeniging 'Nazorg'. Op de oprichtingsbijeenkomst hield Pier de Boer een rede. ${ }^{421}$

De statuten van de nieuwe vereniging gaven aan op welke doelgroep zij zich richtte en welke middelen zij dacht te gaan gebruiken:

"Art. 2

De Vereeniging stelt zich ten doel als bemiddelares op te treden tot het verleenen van steun, hulp of leiding aan onderstaande personen, wonende te Delft en omstreken:

a. psychisch minderwaardigen, tevens maatschappelijk onbruikbaren;

b. psychisch minderwaardigen, tevens maatschappelijk minder bruikbaren;

c. lichamelijk gebrekkigen, tevens maatschappelijk onbruikbaren.

Art. 3

Zij tracht dit doel te bereiken door:

a. de in art. 2 bedoelde personen, hun ouders of verzorgers, zoo noodig met raad en daad ter zijde te staan;

b. de in art. 2 bedoelde personen behulpzaam te zijn in het zoeken naar een voor hen passende betrekking of bij hun opleiding voor eenig vak of beroep;

c. het bevorderen hunner intellectueele, moreele en godsdienstige ontwikke ling;

d. het stichten en in stand houden eener werkinrichting;

e. andere wettige middelen, die aan het doel bevorderlijk kunnen zijn. ${ }^{422}$

Er was voor een brede doelgroep gekozen, aangeduid als 'psychisch minderwaardigen', waaronder ook psychiatrische patiënten konden vallen. Ook lichamelijk gebrekkigen werden in de statuten genoemd, maar in de praktijk beperkte men zich tot slechts één groep, namelijk de oud-leerlingen van het Delftse BLO.

Aan het einde van 1927 kende de gemeente Delft de vereniging subsidie 
toe. De zaken werden voortvarend aangepakt en op 16 januari 1928 werd de Delftse werkinrichting voor jongens geopend. Er zouden binnen korte tijd 23 oudleerlingen tewerkgesteld worden. ${ }^{43}$ In februari 1928 werd Van Der Wouden door de vereniging aangesteld als voltijds nazorgambtenaar. Het eerste jaar van zijn werkzaamheden beperkte hij zich tot de gang van zaken op de werkinrichting en het organiseren van het avondonderwijs. Met de inhoud van dat onderwijs hoefde hij zich niet te bemoeien. De verantwoordelijkheid daarvoor lag bij de hoofden van de beide scholen voor BLO, één openbare en één katholieke, zodat het levensbeschouwelijke karakter van de avondverzorging gegarandeerd was. De vereniging zorgde alleen voor de financiering. ${ }^{424}$

Bij het ontstaan van de Utrechtse nazorg speelde de inspecteur voor het BLO Van Voorthuijsen een prominente rol. Hij hechtte er kennelijk grote waarde aan, dat in de stad waarin zijn inspectie kantoor hield aan nazorg voor oud-leerlingen van het BLO werd gedaan. Dat had waarschijnlijk te maken met de wijze waarop Van Voorthuijsen tegen zwakzinnigenzorg in het algemeen en nazorg in het bijzonder aankeek. Hij legde in verschillende artikelen die in de loop van de jaren twintig verschenen de nadruk op het belang van een samenhangende zwakzinnigenzorg, die zwakzinnigen van de wieg tot het graf in de gaten hield en zo het risico dat zwakzinnigen voor de samenleving betekenden zoveel mogelijk beperkten. ${ }^{425}$

Begin 1927 vergaderde een Commissie van Voorbereiding over de oprich-

ting

"... eener Vereeniging, welke zich ten doel stelt te voorzien in verschillende behoeften van leerlingen en oud-leerlingen der school voor buitengewoon onderwijs te Utrecht ${ }^{\text {4226 }}$

Van Voorthuijsen zette op deze bijeenkomst zijn persoonlijke visie op de Utrechtse nazorg uiteen. Hij wilde dat de nazorg aan het particulier initiatief zou worden overgelaten. In zijn opinie zouden zowel leerlingen als oud-leerlingen van het BLO tot de doelgroep moeten behoren. De organisatie zou zich, naast de nazorg, ook moeten bezighouden met de ondersteuning van de scholen voor BLO zoals dat in die jaren gebruikelijk was: ze zou moeten zorgen voor de uitzending van kinderen naar gezondheidskolonies, schoolfeesten organiseren en kinderen uit armlastige gezinnen ondersteunen. ${ }^{427}$ Ook zou de vereniging een taak moeten hebben bij het plaatsen van leerlingen op internaten. ${ }^{428}$ Verder pleitte hij voor de aanstelling van een nazorgambtenaar ${ }^{429}$ en de oprichting van een werkinrichting voor de oudleerlingen van de bezinkingsklassen, in eerste instantie alleen voor jongens.

Tot daadwerkelijke activiteiten zou het voorlopig niet komen. Er werd alleen een onderzoek gedaan naar de vraag, of er behoefte bestond aan een werkinrichting. Hieruit bleek dat er 6 mannen en 5 vrouwen waren die voor plaatsing op zo'n inrichting in aanmerking kwamen. ${ }^{430}$ In 1928 bezocht een delegatie van het bestuur de Vlaardingse werkinrichting om zich te oriënteren op de wijze waarop zoiets moest worden aangepakt. Er werd een Fonds voor de Werkinrichting opgericht, dat geld inzamelde. ${ }^{431}$ Het zou tot 1930 duren voordat de werkinrichting $\mathrm{Ar}$ beidsvreugde kon worden geopend. Er werkten in eerste instantie 7 jongens. ${ }^{42}$ De gemeente Utrecht droeg fl. 1000,- ( $€ 455,-)$ bij voor de eerste inrichting en fl. 200,- 
( $€ 91,-)$ per jaar per pupil die er op advies van de GG\&GD werd geplaatst. ${ }^{433}$ Een ambtenaar voor de nazorg zat er voorlopig niet in. De zorg voor de oud-leerlingen bleef in Utrecht een taak van het onderwijzend personeel van het BLO.

In Schiedam werd op 8 juli 1928 de vereniging Zwakzinnigenzorg opgericht, die zich richtte op de leerlingen en oud-leerlingen van de school voor $\mathrm{BLO}{ }^{434} \mathrm{Al}$ heel snel ging men over tot de stichting van een werkinrichting voor jongens, die op 3 september 1928 opende. ${ }^{435}$ De provincie Zuid-Holland verleende hiervoor, zoals in Dordrecht, Vlaardingen en Delft een subsidie. ${ }^{436}$ In 1931 werkten er 9 jongens. ${ }^{437}$ Andere nazorgactiviteiten vonden in Schiedam in deze periode niet plaats.

In Arnhem ontstond de Nazorg op initiatief van de plaatselijke afdeling van O\&A. Op 24 november 1927 hield P.G. Schreuder, directeur van huize 'Zonneschijn' (voorheen 'Klein Warnsborn') en betrokken bij het ontstaan van het BLO in Den Haag (zijn broer, P.H. Schreuder volgde hem op als hoofd van de eerste BLOschool daar) een inleiding over de 'maatschappelijke taak en maatschappelijk doel der scholen voor zwakzinnigen' aan de hand van de Haarlemse nazorgrapporten. ${ }^{438}$ Het leidde tot een discussie over de invulling van de nazorg waarbij men het niet eens werd over de vraag, hoe dat zou moeten gebeuren. Wel vond men het belangrijk dat de band tussen school en oud-leerling gehandhaafd bleef,

"...d.i. de kinderen zoolang mogelijk te brengen in een gezond milieu onder paedagogische leiding en de leerlingen te behoeden voor de gevaren van de straat. ${ }^{439}$

Verder besloot men om een adres aan de Arnhemse gemeenteraad te richten, om deze voor te lichten over de nazorg. ${ }^{440}$ Dat had kennelijk succes, want de regeling van de nazorg kwam in februari 1928 tot stand.

"Het stelsel van Dordrecht werd als voorbeeld genomen. Er komt een ambtenaar, die zijn geheele vrije tijd aan dit werk zal wijden. ${ }^{\text {.441 }}$

H. Werkhoven, afkomstig uit het gewoon lager onderwijs, werd door de gemeente als nazorgambtenaar aangesteld, eerst tijdelijk, in 1929 definitief. Werkhoven kreeg toen ook een voltijds aanstelling. ${ }^{442}$ De avondverzorging werd in 1929 gemeentelijk geregeld, ${ }^{443}$ en een werkinrichting op het landgoed 'Presikhaaf' startte in $1930 .{ }^{444}$ Werkhoven werd tot directeur benoemd. Hij was de eerste in Nederland, die tuinarbeid in het pakket van de werkinrichting opnam. ${ }^{445}$

De ontstaansgeschiedenis van de Bredase nazorg was erg gecompliceerd. De aanzet ertoe lag bij de start van de buitendienst van het katholieke krankzinnigengesticht Huize Voorburg in Vught. Deze buitendienst hield wekelijks spreekuren in de grootste Brabantse steden, waaronder Breda. ${ }^{446}$ Eén van de taken van deze spreekuren was het 'zoeken van passende arbeid voor geestelijk onvolwaardigen'. ${ }^{447} \mathrm{Bij}$ het BLO in Breda leidde dit tot de conclusie dat er iets aan nazorg voor haar leerlingen gedaan moest worden om te voorkomen dat dezen in handen van de psychiatrie zouden vallen. Onder het motto 'if you can't beat them, join them' werd er nadrukkelijk samenwerking gezocht met de buitendienst van Voorburg. De Stichting Nazorg werd opgericht door de Broeders van Huybergen, die de Bredase 
BLO-school voor jongens exploiteerden. ${ }^{448}$ De secretaris van deze stichting, Th. J. Potters, directeur van de Bredase meisjesschool voor BLO en het daaraan verbonden internaat Sint-Rosa zocht namens de stichting aansluiting bij het Consultatiebureau voor Zenuw-en Zielszieken van de buitendienst van Huize Voorburg. ${ }^{449} \mathrm{Hij}$ startte een Paedagogisch Consultatiebureau, 'onder medische en psychiatrische controle', dat zich bezighield met de keuring van kandidaat-leerlingen voor de scholen voor BLO en oud-leerlingen testte op arbeidsgeschiktheid en mate van maatschappelijke aanpassing. Het concrete nazorgwerk werd ondergebracht in de nazorgcentrale. Potters was er de ambtenaar voor de maatschappelijke zorg. ${ }^{450}$ Doel van de stichting Nazorg was de

"Bescherming van geestelijk- en lichamelijk onvolwaardigen."

Voor het bereiken van de doelstellingen had men zich zes deeltaken gesteld:

"1. Het verlenen van maatschappelijk-geestelijk-morele bijstand.

2. Het geven van paedagogische adviezen voor moeilijk-opvoedbare kinderen.

3. Het steunen bij plaatsing in internaten en kosthuizen.

4. Het oprichten en instandhouden van werkinrichtingen.

5. Het bevorderen van onderwijs-en ontspanningcursussen.

6. Patronage in de ruimste zin. ${ }^{.452}$

De nazorg in Groningen kende een lange voorgeschiedenis, die ik voor een deel al heb behandeld in paragraaf 1.3.3. De oorsprongen lagen in de jaren tien van de twintigste eeuw, met de oprichting van een plaatselijke afdeling van de Centrale Vereeniging ter Behartiging van de Belangen van Zwakzinnigen, waarbij onder andere Van Voorthuijsen betrokken was. Van echte activiteiten was pas sprake aan het einde van de jaren twintig. De afdeling was toen inmiddels verzelfstandigd tot de vereniging Zwakzinnigenzorg. Op 1 mei 1929 opende een werkinrichting voor jongens de deuren, mede dankzij een gemeentelijke subsidie van fl. 3000,- ( $€$ $1364,-) .{ }^{453}$ De vereniging hield zich afzijdig van landelijke ontwikkelingen op nazorggebied. ${ }^{454}$

In de loop van de jaren twintig werden er verder nog initiatieven genomen om tot nazorg te komen in Assen, Alkmaar, Apeldoorn, Dieren, Gouda, Hilversum, Rheden en Velp. Tot een daadwerkelijke invulling van de zorg voôr oud-leerlingen van het BLO kwam het in deze plaatsen gedurende de jaren twintig niet.

De twee steden waar de eerste experimenten met vormen van nazorg waren genomen, Den Haag en Rotterdam, ontbreken bij deze 'tweede golf' van nazorginstellingen. Dat had in beide gevallen, zoals al eerder aangegeven, te maken met de wet van de remmende voorsprong.

In Rotterdam bestonden de ambachtscursussen voor zwakzinnigen en er werd vanaf 1919 avondonderwijs verzorgd, twee avonden per week. ${ }^{455}$ Vanaf het midden van de jaren twintig werd duidelijk, dat dat onvoldoende was. Zo bleek dat van de ruim 1300 leerlingen, die het BLO in Rotterdam tussen 1896 en 1911 hadden verlaten, er 1200 geheel uit beeld waren verdwenen. Het was niet duidelijk wat er met hen in hun verdere leven was gebeurd. ${ }^{456}$ Alleen van de 110 oud-leerlingen 
van de ambachtscursussen was iets bekend, en dat was niet bemoedigend.

"In de zestien jaren, dat deze cursus bestaan heeft, zijn er aan de maatschappij afgeleverd 52 boekbinders, en 58 schoenmakers tezamen 110 , dat is gemiddeld 7 per jaar.

Van die 110 zijn er bij het beroep, waarvoor ze werden opgeleid gebleven slechts 25 , te weten: 13 boekbinders en 12 schoenmakers. ${ }^{457}$

De ambachtscursussen voldeden niet, zoals ook in een ambtelijke notitie aan de wethouder van onderwijs werd vastgesteld:

"Niet opleiding voor een bepaald vak, maar vergrooting van de algemeene paraatheid en vaardigheid moet het doel zijn." ${ }^{458}$

Het leidde tot een onderzoek naar wat er verbeterd zou kunnen worden aan de nazorg voor oud-leerlingen van het Rotterdamse BLO. De gemeente gaf daartoe opdracht aan L. Bodaan, Ambtenaar voor Advies inzake de Opvoeding van de Rijpen Jeugd. Die concludeerde in een rapport dat in maart 1927 uitkwam, dat een werkinrichting en een ambtenaar voor de nazorg in Rotterdam hard nodig waren. In december 1929 besloot de Rotterdamse gemeenteraad dat een dergelijke ambtenaar aangesteld moest worden, maar het zou nog tot 1931 duren voordat dat daadwerkelijk gebeurde. Onder de sollicitanten waren onder andere Wepster en Van der Wouden, maar Bodaan kreeg uiteindelijk de functie, die hij naast zijn andere werk moest uitvoeren. ${ }^{459}$ Bodaan hield zich afzijdig van de landelijke ontwikkelingen op het gebied van de nazorg.

In Den Haag was er, na het ter ziele gaan van de patronaatsvereniging van Zorg voor ' $t$ Achterlijke Kind in 1919 niet veel aandacht meer voor nazorg. Pas in 1926 kwam het onderwerp weer aan de orde in het College van Burgemeester en Wethouders. ${ }^{460}$ Dat leidde in 1928 tot de instelling van een onderzoekscommissie,

"...welke voorstellen zal doen nopens de nazorg voor de ontslagen leerlingen der openbare en bijzondere scholen voor buitengewoon lager onderwijs in deze Gemeente en welke eventueel met de uitvoering dier voorstellen geheel of ten deele zal kunnen worden belast." ${ }^{461}$

Het verslag van deze commissie werd in 1930 gepubliceerd en leek in veel opzichten op de eerdere rapporten in Amsterdam en Haarlem. Het bevatte een aantal onderzoeken naar de toestand van de oud-leerlingen van het BLO en deed de gebruikelijke aanbevelingen om de nazorg in Den Haag tot stand te laten komen. Nieuw element in dit Haagse nazorgrapport was dat de achtergronden van de oudleerlingen van het BLO nader werden beschouwd. Voor het eerst werd onderzocht uit welke milieus de oud-leerlingen stamden. Ook werd er onderzocht, in hoeverre oud-leerlingen in aanraking waren gekomen met politie en justitie. ${ }^{462}$ Naar beide deelonderzoeken zou in de loop van de jaren dertig veelvuldig worden verwezen. Tot een daadwerkelijke invulling van de nazorg zou het in Den Haag pas aan het einde van de jaren dertig komen.

Met betrekking tot aantallen nazorgpupillen zijn maar weinig gegevens bewaard gebleven. Pas aan het einde van de jaren twintig begon het Centraal $\mathrm{Bu}$ reau voor de Statistiek met het vastleggen van gegevens met betrekking tot aantal- 
len leerlingen die het BLO verlieten. Specifieke gegevens over de nazorg werden toen nog niet vastgelegd. In 1929 verlieten in totaal 1584 kinderen de scholen voor BLO. Van deze groep waren er 810 oud-leerlingen van wie de gegevens werden vastgelegd. Of het hier om kinderen ging die onder de nazorg vielen is niet duidelijk, maar dit getal is op zijn minst een indicatie van hun aantal. Van deze groep waren er 753 als debiel en 57 als imbecil geclassificeerd. Van de debielen vonden er 569 werk in het vrije bedrijf, van de imbecillen 21 . Twintig debielen werden op een werkinrichting geplaatst, evenals 13 imbecillen. In totaal kwamen er 154 kinderen, vooral meisjes, in het eigen gezin terecht. Van 33 oud-leerlingen waren geen gegevens bekend. ${ }^{463}$

\subsubsection{Financiering van de nazorg}

Vrijwel alle nazorginstellingen en werkinrichtingen waren voor hun financiering van externe bronnen afhankelijk. Alleen de Haarlemse nazorg, die geheel in gemeentelijke handen was, hoefde geen gelden van buiten te werven. Alle andere instellingen waren geheel of gedeeltelijk afhankelijk van gemeentelijke en provinciale subsidies, werving van fondsen onder particulieren en de verkoop van de producten van de werkinrichting. Breda was de enige nazorginstelling die overheidssubsidiëring afwees. De broederorde die voor de nazorg verantwoordelijk was, gebruikte als motto 'nazorg op charitatieve grondslag'. ${ }^{464}$

Het bleek betrekkelijk eenvoudig om gemeenten over te halen de nazorg financieel te ondersteunen. De stelling dat nazorg de duurdere gestichtsverpleging van zwakzinnigen kon voorkomen, werd algemeen geaccepteerd. Aan het einde van de jaren twintig liet bijvoorbeeld de gemeente Amsterdam onderzoeken waarom de kosten van gestichtsverpleging zo waren toegenomen. In haar eindrapport, dat in paragraaf 5.2.2 ook al aan de orde is geweest, gaf de onderzoekscommissie aan de nazorg te beschouwen als een goed middel om op de kosten van gestichtsverpleging te bezuinigen, omdat door de nazorg aanzienlijk minder zwakzinnigen naar gestichten hoefden te worden overgebracht. ${ }^{465}$ Of deze bewering juist was viel niet te controleren, omdat het niet mogelijk was om vast te stellen, hoeveel verpleegkosten er niet gemaakt werden doordat de nazorg bestond. Er kon hoogstens een vergelijking worden gemaakt met gemeenten waar nazorg niet bestond, zoals Den Haag. Het Haagse nazorgrapport van 1930 liet zien dat van in totaal 726 onderzochte oud-leerlingen ( 505 jongens, 221 meisjes) er in totaal 43 in een gesticht verbleven of hadden verbleven, waarvan 6 in een weeshuis, 6 in gestichten voor misdadige jongens, 6 in gestichten voor tuchtelooze en verwaarloosde meisjes en 25 (20 jongens, 5 meisjes) in zwakzinnigengestichten. ${ }^{466}$ Het lijkt erop te wijzen, dat ook bij het ontbreken van nazorg niet veel oud-leerlingen van het BLO in gestichten terechtkwamen. Dit deel van het Haagse nazorgrapport, dat op allerlei andere punten druk werd geciteerd, werd amper aangehaald.

In de jaren twintig was er één provinciale overheid, die van Zuid-Holland, die werkinrichtingen voor zwakzinnigen subsidieerde door een klein bedrag per uur per tewerkgestelde uit te keren. Om deze subsidie te ontvangen, moest de werkinrichting wel lid zijn van de Centrale Vereeniging ter Behartiging van de Belangen van Zentw-en Zielszieken, die voor de provincie als subsidieverdeler optrad. Alle Zuid-Hollandse nazorginstellingen maakten van deze extra subsidiebron gebruik. 
Het argument dat door nazorg te financieren er op andere kostenposten een groter bedrag kon worden bezuinigd, was niet de enige reden waarom overheden bereid waren er geld aan uit te geven. Er speelde ook een urgentiegevoel rondom de problematiek van zwakzinnigen en zwakzinnigheid. Jaarlijks leverde het BLO een nieuw contingent oud-leerlingen af, dat in de maatschappij moest worden opgenomen. Het negatieve beeld dat over zwakzinnigheid bestond en de latente eugenetische angst ervoor leidden ertoe dat bij lokale en enkele provinciale bestuurders het besef ontstond dat er iets met deze groep gedaan moest worden om grotere problemen in de toekomst te voorkomen. De nazorg speelde handig op dat gevoel in, door voor deze groep zorg aan te bieden tegen een, vergeleken met de gestichtverzorging, schappelijke prijs.

Onder betrokkenen bij de nazorg werd er bij subsidieaanvraag en subsidieverlening nauwgezet voor gewaakt dat de hulp aan oud-leerlingen van het BLO niet als een onderdeel van de armenzorg werd behandeld. Nazorgwerkers zagen hun werk als een onderdeel van het onderwijs of van de geestelijke gezondheidszorg, maar nadrukkelijk niet van de liefdadigheid. Deze houding wordt onder andere duidelijk in Delft, waar in 1928 de vereniging Nazorg subsidie aanvroeg bij de provincie Zuid-Holland voor de werkinrichting. $\mathrm{Zij}$ wilde dat uitdrukkelijk niet doen onder de noemer van 'Instellingen van Weldadigheid'. De secretaris van de vereniging, de latere sociaal-democratische minister-president Schermerhorn, legde uit waarom dat zo was:

"Volgens hem is de taak onzer Vereeniging het wegnemen van een handicap, die de geestelijk minderwaardigen in den strijd om het bestaan ondervinden. De gemeenschap heeft de plicht voor deze menschen omstandigheden te scheppen, waarbij het hen mogelijk wordt arbeid te leveren, die het hun mogelijk maakt in hun onderhoud te voorzien. Hierin ligt een verschil ten opzichte van de bedeeling en liefdadigheid. ${ }^{467}$

Ook in het Haagse nazorgrapport werd verband met de armenzorg afgewezen, vooral in het belang van de oud-leerlingen van het BLO zelf,

"...opdat het zelfgevoel, aansprakelijk voor iets zijn, verantwoordelijk ergens voor zijn, wordt opgewekt en versterkt. ${ }^{468}$

Subsidies en andere inkomsten werden voor verschillende onderdelen van het nazorgwerk gebruikt. Allereerst werd er het salaris van de nazorgambtenaar van betaald. Deze verdiende in de meeste gevallen een basissalaris dat net zo hoog was als dat van een schoolhoofd, met daarbovenop nog eens een toeslag. Het basissalaris lag in de jaren twintig zo rond de fl. 4200,- $(€ 1909,-)$ per jaar, de toeslag varieerde tussen fl.400,- ( $€ 182,-)$ per jaar in Haarlem tot bijna fl. 1000,- $(€ 455,-)$ in Amsterdam. Nazorgwerkers verdienden goed. Dat had te maken met de grote verantwoordelijkheid die ze droegen en de enorme werkdruk waarmee ze moesten omgaan. Aan de hoogte van het salaris konden de nazorgwerkers ook hun sociale positie afleiden, die hoger was dan een hoofd der school. Dat was belangrijk, want nazorgwerkers moesten zich staande houden in een werkveld waarin ze aan de ene kant veel met onderwijzers en schoolhoofden te maken hadden en aan de andere kant met psychiaters en andere medici, die over het algemeen zeer aan hun status hechtten. 
Tabel 9

Subsidie werkinrichtingen 1928 in guldens ${ }^{469}$

(het getal tussen haakjes is het bedrag in euro's).

\begin{tabular}{lllll}
\hline & Gemeente & Provincie & $\begin{array}{l}\text { Aantal leer- } \\
\text { lingen }\end{array}$ & $\begin{array}{l}\text { Geschatte } \\
\text { totale subsi- } \\
\text { die per jaar** }\end{array}$ \\
\hline Dordrecht & $\begin{array}{l}500,-(227,-) \\
\text { per jaar }\end{array}$ & $\begin{array}{l}0,05(0,023) \\
\text { per uur per } \\
\text { leerling }\end{array}$ & 13 & $\begin{array}{l}1616,25^{* * *} \\
(734,66)\end{array}$ \\
\hline $\begin{array}{l}\text { Amster- } \\
\text { dam* }\end{array}$ & $\begin{array}{l}250,-(114,-) \\
\text { per jaar per } \\
\text { leerling }\end{array}$ & n.v.t. & 32 & $\begin{array}{l}2400,,^{* * * *} \\
(109,-)\end{array}$ \\
\hline Haarlem & $\begin{array}{l}200,-(91,-) \\
\text { per jaar per }\end{array}$ & n.v.t. & 27 & $\begin{array}{l}2600,- \\
(1182)\end{array}$ \\
\hline Vlaardingen & $\begin{array}{l}0,10(0,045) \\
\text { per uur per } \\
\text { leerling }\end{array}$ & $\begin{array}{l}0,05(0,023) \\
\text { per uur per } \\
\text { leerling }\end{array}$ & 13 & $\begin{array}{l}2184,- \\
(993,-)\end{array}$ \\
\hline Delft & $\begin{array}{l}200,-(91,-) \\
\text { per jaar per }\end{array}$ & $\begin{array}{l}100,-(45,-) \\
\text { per jaar per } \\
\text { leerling }\end{array}$ & 10 & $\begin{array}{l}3000,- \\
(1364,-)\end{array}$ \\
\hline Schiedam & $\begin{array}{l}0,10(0,045) \\
\text { per uur per } \\
\text { leerling }\end{array}$ & $\begin{array}{l}0,05(0,023) \\
\text { per uur per } \\
\text { leerling }\end{array}$ & onbekend & Onbekend \\
\hline
\end{tabular}

"Amsterdam: 1925.

** het aantal tewerkgestelden maal de subsidie per leerling.

**Dordrecht: precieze overheidssubsidie $1928^{470}$

****Amsterdam: maximale subsidie.

Het tweede onderdeel van het nazorgwerk waaraan de inkomsten werden besteed, waren de werkinrichtingen. De hoogte van de subsidie die men hiervoor kreeg verschilde van gemeente tot gemeente en was meestal gerelateerd aan het aantal oud-leerlingen dat er was tewerkgesteld. Uit tabel 9 worden de subsidiebedragen van de werkinrichtingen die in 1928 bestonden duidelijk. Deze subsidie dekte nooit alle kosten, want er werd van uitgegaan dat de opbrengst van de verkoop van de producten in de werkinrichting werd gestoken. Deze opbrengst droeg voor een substantieel deel bij aan de dekking van de kosten van een werkinrichting, zoals blijkt uit de cijfers van de Dordtse werkinrichting in tabel 10 .

Tabel 10

Inkomsten en uitgaven werkinrichting Dordrecht zonder subsidie, in guldens ${ }^{471}$ (het getal tussen haakjes is het bedrag in euro's).

\begin{tabular}{llll}
\hline Jaar & Uitgaven & Inkomsten & Negatief saldo \\
1925 & $4614(2097)$ & $2766(1257)$ & $1848(840)$ \\
1926 & $5157(2344)$ & $3220(1464)$ & $1937(880)$ \\
1927 & $6047(2749)$ & $4128(1876)$ & $1919(872)$ \\
1928 & $5808(2640)$ & $4129(1877)$ & $1679(763)$ \\
1929 & $8675(3943)$ & $4582(2083)$ & $4093(1860)$ \\
1930 & $12720(5782)$ & $7465(3393)$ & $5255(2389)$ \\
\hline
\end{tabular}


De verkoop van producten was in elke werkinrichting anders georganiseerd. Frantsen in Vlaardingen schakelde de tewerkgestelden zelf in. $\mathrm{Zij}$ moesten proberen de producten in hun familie- en kennissenkring te slijten. In Delft werd voor de vrije markt geproduceerd, rieten matten voor de glastuinbouw in het Westland. Haarlem had een gegarandeerde afzet bij de overige gemeentelijke diensten. Maar meestal werden de producten huis-aan-huis verkocht vanaf een kar. In Dordrecht werd hiermee in 1924 voor het eerst geëxperimenteerd. ${ }^{472}$ Ook in Vlaardingen werd deze methode vanaf 1928 toegepast:

"Een groote wagen werd gehuurd, de gemaakte spulletjes opgeladen en dan trok FRANTSEN met $z$ 'n beide onderwijzeressen en de onderwijzer er op uit langs 's heeren straten, dorp in dorp uit ... en eer men 't verwacht had, was de koopwaar van de hand gedaan. ${ }^{473}$

Deze verkoopmethode betekende veel werk, maar in de loop der jaren wierp dat z'n vruchten af. Er werd een vaste klantenkring opgebouwd, die ook in tijden van tegenslag bereid was om de producten van de werkinrichting af te nemen.

Als subsidie en opbrengst van verkoop niet voldoende waren om alle onkosten van een werkinrichting te dekken, moesten er andere geldbronnen worden aangeboord. Eén mogelijkheid was het aanvragen van financiële hulp bij particuliere organisaties. De Dordtse werkinrichting ontving bijvoorbeeld in de jaren twintig een jaarlijkse subsidie van fl. 50,- ( $€ 23,-)$ van de Vereeniging tot Nut van 't Algemeen. ${ }^{474}$ Veel vaker deden nazorgwerkers een beroep op het liefdadig netwerk van de gemeente waarin ze werkzaam waren. Er werden roerende stukjes in kranten geschreven, bedelbrieven verzonden aan vermogende burgers en benefietvoorstellingen georganiseerd, van alles dat zou kunnen bijdragen aan het aanvullen van de kas van de nazorginstelling. In de besturen van particuliere nazorginstellingen waren daarom veel vertegenwoordigers van deze lokale liefdadige infrastructuur, meestal notabelen, opgenomen.

\subsubsection{Maatschappelijke zorg}

De kernactiviteit van de nazorg was de maatschappelijke zorg. Alle andere aspecten van de nazorg waren hiervan afgeleid. Het doel ervan was om oud-leerlingen van het BLO in de maatschappij te houden. In de tweede helft van de jaren twintig ontwikkelde deze maatschappelijke zorg zich inhoudelijk verder. Ook op dit gebied was de Amsterdamse nazorgambtenaar Pier de Boer de belangrijkste publicist. Hij vatte de kern de maatschappelijke zorg samen met het begrip leiding.

"De middelen, die gedurende de schoolperiode aangewend werden om den zwakzinnige staande te houden en hem besef van eigen positie te geven, moeten ook beschikbaar zijn minstens gedurende de eerste jaren, dat de oudleerlingen zich in de maatschappij moeten leeren aanpassen.

Leiding moeten zij hebben; leiding om over hun eigen moeilijkheden heen geholpen te worden, om de moeilijkheden, die zij in huisgezin en werkplaats veroorzaken, uit den weg te ruimen.

Deze leiding is noodzakelijk voor bijna allen.

Voor hen, die in het productieproces onbruikbaar zijn en thuis en op straat voor den duur onoverkomelijke bezwaren zullen opleveren. 
De verkoop van producten was in elke werkinrichting anders georganiseerd. Frantsen in Vlaardingen schakelde de tewerkgestelden zelf in. Zij moesten proberen de producten in hun familie- en kennissenkring te slijten. In Delft werd voor de vrije markt geproduceerd, rieten matten voor de glastuinbouw in het Westland. Haarlem had een gegarandeerde afzet bij de overige gemeentelijke diensten. Maar meestal werden de producten huis-aan-huis verkocht vanaf een kar. In Dordrecht werd hiermee in 1924 voor het eerst geëxperimenteerd. ${ }^{472}$ Ook in Vlaardingen werd deze methode vanaf 1928 toegepast:

"Een groote wagen werd gehuurd, de gemaakte spulletjes opgeladen en dan trok FRANTSEN met $z$ 'n beide onderwijzeressen en de onderwijzer er op uit langs 's heeren straten, dorp in dorp uit ... en eer men 't verwacht had, was de koopwaar van de hand gedaan. ${ }^{4773}$

Deze verkoopmethode betekende veel werk, maar in de loop der jaren wierp dat z'n vruchten af. Er werd een vaste klantenkring opgebouwd, die ook in tijden van tegenslag bereid was om de producten van de werkinrichting af te nemen.

Als subsidie en opbrengst van verkoop niet voldoende waren om alle onkosten van een werkinrichting te dekken, moesten er andere geldbronnen worden aangeboord. Eén mogelijkheid was het aanvragen van financiële hulp bij particuliere organisaties. De Dordtse werkinrichting ontving bijvoorbeeld in de jaren twintig een jaarlijkse subsidie van fl. 50,- ( $€ 23,-)$ van de Vereeniging tot Nut van 't Algemeen. ${ }^{474}$ Veel vaker deden nazorgwerkers een beroep op het liefdadig netwerk van de gemeente waarin ze werkzaam waren. Er werden roerende stukjes in kranten geschreven, bedelbrieven verzonden aan vermogende burgers en benefietvoorstellingen georganiseerd, van alles dat zou kunnen bijdragen aan het aanvullen van de kas van de nazorginstelling. In de besturen van particuliere nazorginstellingen waren daarom veel vertegenwoordigers van deze lokale liefdadige infrastructuur, meestal notabelen, opgenomen.

\subsubsection{Maatschappelijke zorg}

De kernactiviteit van de nazorg was de maatschappelijke zorg. Alle andere aspecten van de nazorg waren hiervan afgeleid. Het doel ervan was om oud-leerlingen van het BLO in de maatschappij te houden. In de tweede helft van de jaren twintig ontwikkelde deze maatschappelijke zorg zich inhoudelijk verder. Ook op dit gebied was de Amsterdamse nazorgambtenaar Pier de Boer de belangrijkste publicist. Hij vatte de kern de maatschappelijke zorg samen met het begrip leiding.

"De middelen, die gedurende de schoolperiode aangewend werden om den zwakzinnige staande te houden en hem besef van eigen positie te geven, moeten ook beschikbaar zijn minstens gedurende de eerste jaren, dat de oudleerlingen zich in de maatschappij moeten leeren aanpassen.

Leiding moeten zij hebben; leiding om over hun eigen moeilijkheden heen geholpen te worden, om de moeilijkheden, die zij in huisgezin en werkplaats veroorzaken, uit den weg te ruimen.

Deze leiding is noodzakelijk voor bijna allen.

Voor hen, die in het productieproces onbruikbaar zijn en thuis en op straat voor den duur onoverkomelijke bezwaren zullen opleveren. 
de nazorgambtenaar zouden steunen in zijn beroepskeuzeadvies ten opzichte van het kind.

" Deze besprekingen zijn van belang, niet alleen, omdat de beslissingen voor het kind verstrekkend kunnen zijn, maar ook en vooral, om de ouders zoo noodig en mogelijk een juist inzicht in den toestand van het kind te geven, de medewerking voor de te volgen weg te verkrijgen en de samenwerking van Nazorg en huisgezin voor den komenden tijd te bewerkstelligen." ${ }^{478}$

Als eenmaal duidelijk was, welk beroep geschikt was en die keuze door ouders en kind werden geaccepteerd, kon de fase van het werk zoeken beginnen. Het was volgens De Boer érg belangrijk dat de juiste keuze gemaakt werd, vanwege de grote waarde die hij, en met hem alle nazorgwerkers, hechtten aan het verrichten van arbeid bij de maatschappelijke integratie van oud-leerlingen van het BLO. De stelling was,

"... dat naast leiding regelmatige arbeid de voornaamste factor is, om den abnormale voor zichzelf en voor de gemeenschap te bewaren. Het brengt regelmaat in het leven en regelmaat is voor den abnormale, wat de versterkende middelen zijn voor het zieke lichaam. Het verhoogt den weerstand. Hun energie moet zich kunnen richten op nuttige dingen. De normale ondergaat m.i. niet ongestraft langdurige werkloosheid. Voor den abnormale is het een vloek. Ik vermoed, dat hierover weinig verschil van meening zal zijn. ${ }^{449}$

Over de rol van de nazorgambtenaar bij het zoeken van een passende baan verschilden de meningen onder nazorgwerkers enigszins. Wepster, de Dordtse nazorgambtenaar, vond dat het zoeken van een betrekking voor een oud-leerling in eerste instantie een taak van de ouders was en dat de nazorgambtenaar pas in tweede instantie hierin een rol te vervullen had, als het moeilijk bleek geschikt werk te vinden.

"Men overdrijve dit in geen geval. Soms hoort men de meening verkondigen, als zou de ambtenaar voor de nazorg ook steeds moeten zorgen voor een geschikte betrekking. Niets is minder juist.

De ouders zijn en blijven de natuurlijke verzorgers.

Zij zijn, na overleg met den leider in de eerste plaats aangewezen er op uit te gaan. Slagen zij niet, of is hulp noodig, dan eerst is het tijd op te treden. ${ }^{480}$

De Boer was het in zoverre met Wepster eens, dat het de ouders op dit gebied niet al te gemakkelijk gemaakt moest worden. $\mathrm{Zij}$ hadden volgens hem zeker een tak bij het zoeken van werk voor hun kind. Hij vond echter wél, dat de eindverantwoordelijkheid ervoor bij de ambtenaar voor de nazorg diende te liggen. ${ }^{481}$

Bij het zoeken naar een passende baan kon de nazorgwerker gebruik maken van de diensten van andere organisaties, zoals de arbeidsbeurs. Het bleek in de loop der jaren echter effectiever om een eigen netwerk van werkgevers op te bouwen, die bereid waren om oud-leerlingen van het BLO in dienst te nemen. Dat was een érg tijdrovend en intensief werk, omdat zo'n netwerk alleen kon worden opgebouwd door middel van veel persoonlijke contacten. Pier de Boer stelde in dit verband: mijn instrumenten zijn mijn schoenen ${ }^{482}$ De dagboeken van de Maastrichtse nazorgwerkster Majoie uit de jaren dertig, de enige directe documentatie van de dage- 
lijkse werkzaamheden binnen de nazorg die, voor zover mij bekend, bewaard is gebleven, laat zien dat zij zo'n vier tot vijf werkgevers per dag bezocht om haar netwerk in stand te houden en uit te breiden. ${ }^{483}$

Jongens en meisjes werden bij het zoeken naar werk verschillend behandeld. Over het algemeen werd er veel meer tijd en energie gestoken in de arbeidsbemiddeling voor jongens dan voor meisjes. Van meisjes vonden nazorgwerkers het minder erg als ze thuis bleven. Ze veronderstelden dat zij daar in de huishouding zouden worden ingezet. Als meisjes wél aan werk geholpen werden, was dat meestal in een betrekking die van huishoudelijke arbeid was afgeleid, als dienstbode bijvoorbeeld, wasvrouw of strijkster.

Als een oud-leerling in werk geplaatst was, begon de maatschappelijke zorg, het eigenlijke leidinggeven, pas écht. Voorkomen moest worden dat de oudleerlingen ál te snel ontslag zouden krijgen of nemen. Het snelle en veelvuldige wisselen van werkgever werd beschouwd als één van de belangrijkste problemen van zwakzinnigen die in de maatschappij verbleven. Een deelonderzoek van het Haagse nazorgrapport van 1930 toonde aan, dat het een reëel probleem was. Van een groep van 502 oud-leerlingen van het Haagse BLO die tussen 1905 en 1929 de school hadden verlaten, bleken er 307 meer dan één werkgever te hebben gehad. Deze 307 oud-leerlingen waren in totaal 975 maal van werkgever veranderd, gemiddeld hadden zij tussen drie en vier werkgevers gehad. Deze wisselingen vonden meestal korte tijd nadat de arbeidsovereenkomst was aangegaan plaats. ${ }^{484}$ Dat gaf volgens de nazorgwerkers aan, dat de betrokken oud-leerlingen de maatschappelijke realiteit waarin ze geplaatst waren niet hadden aanvaard en hun eigen rol daarin overschatten.

"Het is de intreding in de maatschappij, die voor onze kinderen zulke groote moeilijkheden meebrengt. Zij zijn dan genoodzaakt het onderscheid tusschen hen en de normalen te demonstreeren. Ze moeten dan vaak ondervinden, dat hun werkprestaties ver beneden het normale peil zijn, zoodat ontslag onverbiddelijk moet volgen. Een nieuwen baas wordt gezocht. Na korten tijd hetzelfde resultaat. En dan komt voor velen de hopelooze periode, dat van den eenen baas naar den anderen wordt gegaan, van het eene vak naar het andere. ${ }^{.485}$

Daarom moest juist deze eerste periode de oud-leerlingen intensief begeleid worden, om conflicten in een zo vroeg mogelijk stadium in de kiem te smoren.

"Indien we (...) na de plaatsing onze oud-leerlingen alleen verder hun weg lieten zoeken, zou moeite en tijd verloren zijn, want nu beginnen de moeilijkheden, vooral in den eersten tijd. De patroon merkt de mindere bruikbaarheid dagelijks. De zwakzinnige voelt zich al spoedig achteruitgezet, verdient te weinig, en komt met bergen klachten thuis. Hier moet door de Nazorg voortdurend een beroep worden gedaan op de welwillendheid van den werkgever, en alle bezwaren van den zwakzinnige en ook vaak van de ouders uit den weg geruimd worden. Na de plaatsing moet de patroon regelmatig worden bezocht, om hem belangstelling te toonen, zoo noodig aanwijzingen te geven, vaak om ontslag te voorkomen. Met het huisgezin moet contact gehouden worden en de oud-leerlingen moeten regelmatig met de Nazorg in aanraking blijven. Tusschen werkgever, huisgezin en oud-leerling zal de Nazorg voortdurend bemiddelaar zijn." ${ }^{-486}$

De dagboeken van Majoie uit de jaren dertig geven een indicatie over de frequentie 
van deze contacten. In de eerste weken na plaatsing van oud-leerlingen bij een werkgever bezocht zij vaak tientallen malen de werkgever en de ouders. Naarmate het dienstverband langer duurde, nam de bezoekfrequentie langzaam af. ${ }^{487}$

Om te voorkomen dat werkgevers een nazorgpupil al bij de eerste problemen zouden ontslaan, vonden nazorgwerkers het erg belangrijk om hen zo volledig en eerlijk mogelijk voor te lichten over wat ze met het in dienst nemen van een oud-leerling te wachten stond.

"Zal de plaatsing eenig resultaat hebben, dan is de eerste voorwaarde, dat de werkgever op de te verwachten moeilijkheden met zijn nieuwe arbeidskracht is voorbereid, en deze niet beschouwt als een hulp, die bij de eerste de beste moeilijkheid op straat gezet mag worden. De werkgever krijgt uitvoerige inlichtingen over de ontwikkeling, aard en bruikbaarheid van den oud-leerling. Zijn medewerking is ingeroepen om te helpen de z.z. aan regelmatige arbeid te wennen en door de eerste moeilijkheden heen te helpen. ${ }^{4}{ }^{4}$

Daarbij moest niet worden uitgegaan van een bijzonder clementie van de werkgever ten opzichte van de bij hem tewerkgestelde oud-leerling:

"Medewerking van de zijde van werkgever en werknemer bij de plaatsing is altijd meer waard dan een hart vol medelijden." 489

Nazorgwerkers hadden een duidelijke voorkeur voor plaatsing van oud-leerlingen in kleine, ambachtelijke bedrijven. Hier zouden de verhoudingen duidelijk en overzichtelijk zijn, waardoor het voor zwakzinnigen makkelijker zou zijn om zich zonder al te grote problemen aan te passen. Fabrieksarbeid werd als een risico beschouwd omdat daar grote groepen mensen samenwerkten wat controle op de onderlinge verhoudingen moeilijk maakte. Daardoor konden zich excessen voordoen als plagen en pesten, zonder dat daar snel actie op kon worden ondernomen. Voor zwakzinnige meisjes werd fabrieksarbeid met nog grotere nadruk ongeschikt bevonden, omdat er voor hen het extra risico bestond van ongewenste seksuele contacten.

Het geven van leiding door de nazorgambtenaar ging verder dan alleen de arbeidssituatie. Tot de taken van de nazorg werden gerekend:

" - Het toezicht op het gedrag op straat,

- Het toezicht op het gedrag in de werkplaats,

- Het toezicht op het gedrag thuis,

- Bemiddelend optreden bij conflicten in de werkplaats met den werkgever

of

met de medearbeiders,

- Optreden bij conflicten, die aanleiding geven tot aanraking met de politie

of de justitie,

- $\quad$ Optreden bij oproeping tot het vervullen van den militieplicht,

- Optreden bij onder voogdijstelling...." ${ }^{490}$

De nadruk op beheersing van zoveel mogelijk aspecten van het leven van oudleerlingen had te maken met de angst, dat zwakzinnigen door hun aanleg sneller maatschappelijk zouden ontsporen dan normale mensen. 
"De remmende of stuwende invloed van den ambtenaar is noodig om (...) pre-

ventief te kunnen werken ten opzichte van moreele of sociale verwildering...." 491

Risicovol gedrag moest zoveel mogelijk worden vermeden. Nazorgwerkers gingen daarbij uit van een soort excespsychologie: kleine, tamelijk onschuldig ogende ondeugendheden zouden kunnen uitgroeien tot grote problemen. Snoepen kon zo verworden tot onmatigheid en uiteindelijk criminaliteit, nodig om de al maar groeiende behoeften te kunnen bevredigen. Bioscoopbezoek stelde een slechte levenswijze ten voorbeeld, vol van dans en plezier, zonder dat duidelijk werd gemaakt dat arbeid nodig was om al dat plezier te kunnen betalen. En straatslenteren kon leiden tot verleiding, contacten met de verkeerde personen en uiteindelijk criminaliteit. Ook militaire dienst werd als een voor zwakzinnigen onverantwoord groot risico beschouwd, vanwege de moeilijke controleerbaarheid van de onderlinge contacten tussen de rekruten. Nazorgwerkers moesten zich daarom inzetten om te voorkomen dat oud-leerlingen van het BLO daadwerkelijk voor militaire dienst zouden worden opgeroepen. ${ }^{492}$

$\mathrm{Bij}$ ongewenst gedrag moest hard en duidelijk worden ingegrepen:

"Bij onbetamelijk gedrag kan door hem worden berispt en wanneer het van ernstigen aard is, in overleg met de ouders, door deze worden gestraft. Is het gedrag van dien aard, dat politie of justitie er mede gemoeid raken, dan kunnen inlichtingen omtrent aanleg en karakter van den jeugdigen delinquent den rechter helpen een juisten strafmaat toe te passen. ${ }^{.493}$

Bij hun hulpverlening maakten alle nazorgwerkers gebruik van een spreekuur, waar oud-leerlingen, hun ouders en andere betrokkenen voor raad en daad terechtkonden. Spreekuren werden meermalen per week gehouden, meestal aan het einde van de middag of in de avonduren, zodat ook werkenden ze konden bezoeken.

Ook kon er op nazorgwerkers een beroep worden gedaan voor materiële hulpverlening. Ze bemiddelden naar instellingen voor armenzorg, bijvoorbeeld voor kleding of schoeisel, in enkele gevallen ook voor bijvoeding. Soms zetten ze zelf hulpverleningsinstrumenten op, bijvoorbeeld in Delft. Hier beschikte Van der Wouden over twee fondsen, één voor 'algemene' hulpverlening, een ander voor de hulp aan individuele pupillen. ${ }^{494}$

De rol van de nazorgwerkers op het gebied van de 'godsdienstige nazorg' was zeer beperkt. Deze werd bijna geheel overgelaten aan de verschillende levensbeschouwelijke stromingen, waartoe de oud-leerlingen behoorden:

"De Godsdienstige Nazorg zal meestal behartigd worden door de gezindten, waartoe de z.z. behoort. Toch kan ook hier weer een voorlichting van de personen, die zich deze Godsdienstige verzorging tot taak hebben, zijn nut hebben. ${ }^{.495}$

Basis van de relatie tussen nazorgwerkers en hun pupillen was een zekere vorm van wederkerigheid. Nazorgwerkers spanden zich voor hun pupillen in bij het vinden van werk, het oplossen van problemen en dergelijke. Zo wisten nazorgwerkers het gezag op te bouwen waardoor ze van hun pupillen konden verwachten dat zij zich aan hun aanwijzingen en richtlijnen zouden houden. Nazorgwerkers investeerden in hun pupillen, waardoor deze hun leiding aanvaardden.

Soms was dat niet genoeg. Als het niet lukte de medewerking van ouders en pupillen te verkrijgen konden nazorgwerkers gebruik maken van een aantal 
machtsmiddelen. Daartoe behoorden onder andere de kinderwetten. In 1921 waren deze uitgebreid met het instituut gezinsvoogdij, een minder vergaande vorm van ingrijpen in de gezinssituatie dan ontzetting of ontheffing. Daarbij moesten ouders hun gezag delen met een gezinsvoogd, die de kinderrechter, eveneens in 1921 ingesteld, adviseerde over wat er met het betrokken kind moest gebeuren. De meeste nazorginstellingen deden aan gezinsvoogdij.

"Voor de z.z. jeugd is het noodzakelijk, dat naast het ouderlijk gezag nog iemand, die bekend geacht kan worden met den aard en de afwijkingen der z.z., toezicht uitoefent op haar gedragingen. De ouders toch zijn meermalen niet in staat voldoende toezicht op hun kinderen uit te oefenen en de opvoeding in de juiste banen te leiden." ${ }^{496}$

De meeste nazorgwerkers traden ook op als reclasseringsambtenaar. Hierdoor konden zij oud-leerlingen begeleiden die met politie en justitie in aanraking waren gekomen en, als het nodig was, dwingend optreden, bijvoorbeeld als oud-leerlingen voorwaardelijk waren veroordeeld.

Ook traden nazorgwerkers op als curator van volwassen oud-leerlingen die niet in staat werden geacht om voor hun eigen - vooral financiële - belangen op te komen.

Het geheel van de maatschappelijke zorg was er vooral op gericht om oudleerlingen te leren zich aan te passen aan de maatschappelijke realiteit. Slechts bij uitzondering werden er pogingen ondernomen om de maatschappij aan de oudleerling aan te passen. Pier de Boer pleitte er in 1926 voor, dat de maatschappij wat meer rekening zou houden met de zwakzinnigen die in haar midden verbleven.

\begin{abstract}
"Het is m.i. noodzakelijk, dat de mentaliteit van de(n) normale ten opzichte van dit vraagstuk zich wijzigt; dat de normale niet de maatschappij voor zich alleen opeischt, maar inziet, dat ook de psychisch misdeelde een mensch is met menschelijke verlangens en behoeften en dat ook de normale moet trachten, het verblijf van de(n) abnormale in de samenleving mogelijk te maken. ${ }^{497}$
\end{abstract}

Deze algemene opmerking richtte De Boer vooral op de gemeente Amsterdam, die weigerde oud-leerlingen van het BLO in dienst te nemen voor functies, waarvoor ze wél geschikt waren. Hij vond dat de gemeente Amsterdam op dit gebied het goede voorbeeld zou moeten geven aan andere werkgevers.

\begin{abstract}
"Als (gemeente)ambtenaar van de Nazorg betoog ik bij particuliere werkgevers, dat het eenvoudige werk gereserveerd moet worden voor hen, die het moeilijke niet kunnen doen. De grootste werkgever van Amsterdam, n.l. de gemeente zelf, die over verreweg den meesten ongeschoolden arbeid beschikt, heeft zich zelf door een stelsel van reglementen en verordeningen gebarricadeerd, waardoor plaatsing van deze minder bruikbare krachten uitgesloten is." ${ }^{.998}$
\end{abstract}

Er deden zich meer moeilijkheden voor op het gebied van de arbeidsvoorziening voor oud-leerlingen van het BLO. Zo was er lange tijd een meningsverschil met de vakverenigingen over de contractlonen. Vakbonden en werkgevers sloten in een aantal bedrijfstakken collectieve arbeidscontracten (voorlopers van de tegenwoordige Collectieve Arbeids Overeenkomsten, $C A O$ 's) waarin onder andere werd vastgelegd, hoe hoog de lonen minimaal behoorden te zijn. De vakbonden stonden erop, dat daar op geen enkele wijze van werd afgeweken. Hierdoor werd het erg moeilijk om oud-leerlingen van het BLO in deze bedrijfstakken te plaatsen, omdat 
de arbeidsproductiviteit van de meesten van hen onder die van normale arbeidskrachten lag. Toch moesten zij hetzelfde loon uitbetaald krijgen, waardoor veel werkgevers hen niet in dienst namen. Op een vergadering van de Centrale Vereeniging ter behartiging van de belangen van Zenuw-en Zielszieken in 1926 bracht Pier de Boer dit probleem naar voren.

"De Heer de BOER zegt, dat in vele bedrijven, ook voor ongeschoolden arbeid, het collectieve arbeidscontract bestaat en het leeftijdsloon geldt. Aan een minderwaardige arbeidskracht heeft men dus kans teveel uit te keeren en nu zijn er gevallen, waarin men dit liever doet, dan in conflict te komen met de vakvereenigingen. Spreker voorziet dan ook wel, dat men op den duur bij het sluiten van contracten rekening zal gaan houden met zwakzinnigen. ${ }^{499}$

De Boer probeerde in discussie te gaan met de vakbonden, om voor oud-leerlingen van het BLO een uitzondering te maken bij de contractlonen. De bonden waren daar erg huiverig voor. $\mathrm{Zij}$ vreesden dat werkgevers een dergelijke regeling zouden misbruiken, zoals een vertegenwoordiger van het NVV in 1928 op het AVOcongres stelde:

"De vakvereeniging kan echter nooit toestaan, dat de onvolwaardigen als loondrukkend element worden gebruikt. Ook in het belang der onvolwaardigen zelf zou zij zich daartegen moeten verzetten. ${ }^{500}$

De vakbonden waren alleen bereid om te onderzoeken wat er voor mensen met een verminderde arbeidsproductiviteit mogelijk was als de belangen van volwaardige arbeidskrachten daarbij niet in gevaar kwamen. ${ }^{501}$

\subsubsection{Werkinrichtingen}

Werden oud-leerlingen van het BLO als onbruikbaar geclassificeerd, niet geschikt voor arbeid in loondienst, dan kwamen ze in aanmerking voor plaatsing op de werkinrichting. ${ }^{502}$ Twee categorieën oud-leerlingen waren hiervoor eerstaangewezen: degenen die de bezinkingsklassen van het BLO hadden gevolgd en imbecil werden genoemd en de debielen die naast hun verstandelijk gebrek ook nog karakter-en omgangsfouten vertoonden. De imbecillen vormden de grootste groep, de gang van zaken op de werkinrichtingen was vooral op hén gericht.

Het uitdrukkelijke doel van de werkinrichting was het voorkomen van gestichtsplaatsing door middel van het verschaffen van arbeid. Hiermee werden de belangen van drie partijen gediend. Allereerst, zoals al eerder aangegeven, de lokale overheid, die minder geld kwijt zou zijn aan de verpleegkosten van armlastige zwakzinnigen. Vervolgens de ouders, die door de werkinrichting voor een groot deel van de dag konden worden ontlast van de verzorging van hun zwakzinnige kinderen. Voor velen van hen was de werkinrichting een uitkomst, zoals bleek vóór de opening van de Delftse werkinrichting.

"Van de ouders van een tiental zwakzinnigen heeft de commissie bericht ontvangen, dat indien te Delft een werkinrichting voor maatschappelijk onbruikbaren mocht worden geopend, het hun aangenaam zou zijn indien hun zoon daar te werk werd gesteld. ${ }^{.503}$

En ten slotte was er het belang van de tewerkgestelde oud-leerlingen zelf, die over het algemeen liever thuis bleven wonen dan geplaatst te worden in een verafgele- 
gen gesticht, zoals De Boer in 1929 verwoordde:

"Het huiselijk milieu (...) heeft voor de z.z., die er in is opgegroeid, zijn liefelijke beteekenis. Ook al uit dit gevoel van thuis zich op andere wijze, dan bij den normale, dan mag daaruit niet de gevolgtrekking worden gemaakt, dat de aanhankelijkheid voor het huiselijk milieu ontbreekt. Het is m.i. een vergrijp tegen onze zwakzinnigen anders, dan in hoogste noodzakelijkheid, tot hunnen interneering te besluiten." ${ }^{504}$

In de praktijk werden werkinrichtingen daarnaast gebruikt als een middel om tot reïntegratie van zwakzinnigen die vanuit gestichten terug wilden keren in de maatschappij. Dat was bijvoorbeeld het geval met de Vlaardingse werkinrichting, toen daar in 1927 een delegatie van de Utrechtse vereniging 'Zwakzinnigenzorg' op bezoek kwam:

"...[Het] bleek ons, dat enkele verpleegden uit een inrichting te Veldwijk-Ermelo zijn teruggekomen en nu thuis kunnen zijn, omdat ze overdag kunnen werken in de werkinrichting. De gemeente hoeft nu de verpleeggelden niet te betalen - een werkinrichting is dus van economisch standpunt bezien, te verdedigen! ${ }^{505}$

De dagelijkse leiding van de werkinrichting was in handen van de nazorgambtenaar. Het toezicht op het werk werd uitgeoefend door een werkmeester of, bij de werkinrichtingen voor meisjes, een leidster. Deze verdeelde het werk, handhaafde de orde en hield de kwaliteit van de geproduceerde artikelen in de gaten.

"Bijzondere oplettendheid eischt dit van hem omdat uit den aard der zaak zijn patiënten van nature slordig zijn en spoedig tevreden met het bereikte resultaat."

Het werk dat op werkinrichtingen werd verricht, was zo eenvoudig mogelijk. Het vlechten van kokosmatten werd als een ideale activiteit voor de jongens beschouwd, omdat het niet moeilijk was, veel lichamelijke inspanning vergde en fouten gemakkelijk konden worden hersteld. Bovendien was er veel vraag naar dit product. In elk Nederlands huishouden waren in die jaren meerdere kokosmatten te vinden. Maar er werd ook ander werk verricht op de werkinrichtingen. Er werden stoelen gemat, borstels gemaakt en rietmatten gevlochten. Voor meisjes werd weven als de meest geschikte activiteit beschouwd, vooral van het wat grovere huishoudtextiel als dweilen, badmatten en theedoeken. Werkinrichtingen voor meisjes werden daarom vaak weefkamer genoemd.

Over de vraag, hoe oud-leerlingen die op een werkinrichting werkten beloond moesten worden, liepen de meningen uiteen. Vrijwel elke werkinrichting hanteerde een eigen systeem, die allemaal één belangrijk kenmerk deelden: 'loon naar werken'. Dat was ook het geval in Dordrecht.

"Een moeilijke zaak is de loonkwestie. Het beste lijkt spreker in de praktijk om Ioon te geven naar gepresteerden arbeid. Toch is een minimum-loon noodig; in sprekers inrichting bedraagt dit f. $2,50,(€ 1,14, \mathrm{LB})$ terwijl het hoogste loon $\mathrm{f} .8$,- ( $€ 3,60$, LB) bedraagt. Het draagt den naam van zakgeld." ${ }^{307}$

Aanvankelijk bestonden er alleen werkinrichtingen voor jongens. Van meisjes werd verondersteld dat zij geen behoefte aan werk buitenshuis zouden hebben: 
"Spreker (Van Voorthuijsen, LB) stelt zich voor, dat de werkinrichting voornamelijk voor jongens zal zijn: de meisjes toch kunnen zich in huis vaak nog nuttig maken." ${ }^{508}$

In de loop van de jaren twintig werd duidelijk, dat er ook voor meisjes een voorziening voor beschutte arbeid moest komen. Schuyt had in 1925 in Haarlem te maken met vier meisjes, die hij graag op een werkinrichting had geplaatst. Hij had bedacht dat zij het beste pantoffels konden maken - 'arbeid meer geschikt voor vrouwen'- maar hij durfde het niet aan om ze samen met de jongens te laten werken. Het huren van een extra werklokaal en het extra toezicht dat nodig zou zijn was hem te duur. Hij stelde daarom voor,

"... eerst gedurende eenige jaren de practische resultaten der Werkinrichting voor jongens af te wachten. Als er dan meer meisjes zijn, kan gekeken worden wat 't beste voor hen kan gebeuren. ${ }^{\text {509 }}$

Wepster kwam in 1926 tot de conclusie, dat op den duur ook voor meisjes plaats zou moeten komen in de werkinrichting.

"Toch zijn mij gevallen bekend, waaruit geconcludeerd kan worden, dat op den duur een afzonderlijke afdeeling voor zwakzinnige meisjes niet gemist kan worden." ${ }^{510}$

Daarom nam hij in 1928 een proef met het tewerkstellen van meisjes. Hij liet hen samen met de jongens in één ruimte werken. Dat bleek geen succes.

"Deze proef kan vrijwel als mislukt beschouwd worden. De aanwezigheid van meisjes, had op sommige jongens een absoluut verkeerden invloed en eischte de grootste oplettendheid van de werkmeester.

Ook de arbeidsprestaties leden er onder." ${ }^{511}$

Frantsen uit Vlaardingen was in datzelfde jaar 1928 de eerste, die een afzonderlijke werkinrichting voor meisjes opende. Dat bleek wél een succes. Een jaar later, in 1929, opende Dordrecht en Haarlem ook een aparte meisjesafdeling en in de jaren die volgden zouden bijna alle werkinrichtingen plaats gaan bieden aan meisjes, steeds in de vorm van een aparte weefkamer.

\subsubsection{Avondverzorging}

Avondverzorging bleef in de tweede helft van de jaren twintig een belangrijk onderwerp van gesprek in nazorgkringen. Algemeen was men het, naar aanleiding van de ervaringen met avondonderwijs in Dordrecht en Haarlem, met elkaar eens dat de nadruk niet op het vermeerderen van schoolse kennis maar vooral op morele beïnvloeding door middel van gezelligheid behoorde te liggen. Dat wilde niet zeggen dat men vond dat het bijbrengen van kennis geheel achterwege moest blijven. Als het van nut was voor de dagelijkse praktijk van het leven van oud-leerlingen, dan moest het zeker gebeuren.

"Wat de intellectueele vakken (lezen, rekenen, taal) betreft, streve men naar een zoo systematisch mogelijk toegepaste werkverdeeling in overeenstemming met de behoeften onzer oud-leerlingen. De jongen, die een krantenwijk heeft en met teruggeven van geld sukkelt, moet in de eerste plaats meer vertrouwd geraken met de geldswaarden; de loopjongen vraagt meer leesroutine enz."${ }^{.512}$ 
Ook vond men het algemeen van belang, dat oud-leerlingen er het belang van arbeid leerden inzien.

"Daarbij moeten de leerlingen weten wat werken, vlijt en inspanning is. Een sfeer van ingespannen arbeid zien we als voorwaarde voor een gezond geestelijk milieu. ${ }^{513}$

Verder was men het er over eens, dat de avondverzorging naar sekse gescheiden diende te gebeuren. Niet alleen om ongewenste contacten te voorkomen, maar ook om het avondonderwijs seksespecifiek te kunnen verzorgen.

"De voorbereiding voor het maatschappelijk leven is al zoo verschillend, dat alleen op dien grond de wenschelijkheid van splitsing reeds duidelijk spreekt. Voor meisjes zal het Huishoud- en Kookonderwijs een beduidend deel van den beschikbaren tijd opeischen. ${ }^{514}$

Het belangrijkste doel van de avondverzorging was de leiding over oud-leerlingen van het BLO uit te breiden naar de avonduren, om het gevaar van verleiding in hun vrije tijd zoveel mogelijk te voorkomen.

"We zouden de jongens, zij die zoo'n zwakken wil hebben, die tot speelbal, als proef dienen van slechte elementen, onttrekken aan 't slecht milieu, waar ze doorgaans hun avonden doorbrengen, o.a. het huisgezin, de straat, de kameraden, de cinema, de kroeg. ${ }^{515}$

Avondverzorging diende in dit opzicht vooral als een surrogaat voor reguliere jeugd- en jongerenverenigingen, waar het vaak moeilijk was voor oud-leerlingen van het BLO om aansluiting te vinden.

"Maar waar moeten we heen met onze geestelijk minderbedeelde jongens en meisjes? De best aangelegden zullen tusschen hun normale soortgenooten een plaats vinden. (...) Maar t.o.v. verreweg het grootste deel onzer oud-leerlingen is dit onbegonnen, dus een ondankbaar werk. 'Onze' rijpere jeugd kan zich in die milieu's niet uitleven en zij die het meeste steun en leiding nodig hebben, vinden bespotting en wenden zich af." ${ }^{516}$

Binnen de avondverzorging diende vooral de nadruk op de morele kant van het leven in de maatschappij te worden gelegd. Dat zorgde ervoor, dat de avondverzorging vrijwel vanaf het eerste begin verzuild werd georganiseerd. Elke levensbeschouwelijke groepering wilde haar eigen moraal overbrengen op haar eigen oudleerlingen. Daarom speelden nazorginstellingen, als zij zich niet richtten op één specifieke levensbeschouwelijke groepering, vaak geen of slechts een marginale rol bij de invulling van de avondverzorging. Deze werd in de meeste gevallen per school apart georganiseerd. Hierdoor was de verspreiding ervan breder dan van de nazorg zelf. In 1928 stond avondverzorging ter beschikking aan oud-leerlingen van 18 van de 65 scholen voor BLO ${ }^{517}$ die toen in Nederland bestonden. ${ }^{518}$ Alleen in Amsterdam zou avondverzorging nooit tot stand komen. De scholen zagen hierin geen taak en het lukte Pier de Boer niet om het gemeentebestuur te overtuigen van het belang ervan. ${ }^{519}$ 


\subsubsection{Registratie van oud-leerlingen}

Binnen de nazorg bestond de overtuiging, dat het erg belangrijk was om de gegevens van oud-leerlingen van het BLO uniform vast te leggen. Zo wilde men een gegevensbestand opbouwen van alle oud-leerlingen van het BLO. Die gegevens konden worden gebruikt in de praktijk van de nazorg, maar waren ook bedoeld voor de toekomst. Als er in een plaats met nazorg werd begonnen, waren de gegevens van de oud-leerlingen al vastgelegd en kon de nieuw aangestelde nazorgwerker gemakkelijker met zijn werk beginnen. Aan het tijdrovende werk van opsporing van oud-leerlingen en de registratie van hun gegevens hoefde hij dan veel minder tijd en energie te besteden. Pier de Boer had in zijn eerste twee praktijkjaren in Amsterdam hiervoor een systeem ontwikkeld, dat in 1925 door E.P. Schuyt verder was uitgewerkt in zijn Rapport over de Maatschappelijke Nazorg voor oud-ll der Buitengewone Scholen te Haarlem. ${ }^{520}$ Dit systeem bestond uit drie archieven. In het eerste hiervan waren de gegevens van alle oud-leerlingen van het BLO opgenomen. Het ging daarbij om naam, adres, leeftijd, ontslagdatum van school, bereikt niveau, godsdienst en gegevens van de ouders. Ook werd aangegeven, welke problematiek er bij de betrokken leerling speelde.

Het tweede archief omvatte de jaarkaarten. Hierop waren de gegevens genoteerd van alle oud-leerlingen die gebruik makten van de diensten van de nazorg. Ze bevatten een verslag van wat er in het lopende jaar met de nazorgpupil was gebeurd en werden elk jaar opnieuw aangemaakt. Er stond onder andere op vermeld door wie de oud-leerling bij de nazorg was aangemeld, gegevens over het arbeidsverleden, het laatstverdiende loon en dergelijke.

Het derde archief bestond uit stamkaarten. Alle oud-leerlingen die ooit met de nazorg in aanraking waren geweest waren er geregistreerd. Elk jaar werden de belangrijkste gegevens van de jaarkaarten er op bijgeschreven. De gegevens bleven bewaard, ook al was de betrokken oud-leerling geen nazorgpupil meer. De bedoeling van dit systeem was, oud-leerlingen langjarig te volgen en hun gegevens nog voorhanden te hebben als ze, misschien wel na jaren, weer een beroep op de nazorg zouden doen. Dit levenslang bewaren van gegevens van oud-leerlingen had te maken met het idee, dat zij altijd zwakzinnig bleven ('eens zwakzinnig, altijd zwakzinnig ${ }^{521}$ ) en daardoor altijd een risico voor de samenleving-vormden.

\subsection{Invloed van de nazorg op het BLO}

In de loop van de jaren twintig ging de nazorg zich bezighouden met de vraag of de lesstof op het BLO kon worden verbeterd om de overgang van school naar maatschappij te vergemakkelijken. Op de jaarvergadering van 1927 van de vereniging O\&A pleitten twee BLO-onderwijzers, C.J. Vos, secretaris van de vereniging, en C. Leeflang, hoofd van één van de openbare BLO-scholen in Rotterdam, voor een betere bescherming van hun oud-leerlingen. $\mathrm{Zij}$ stelden voor de schoolse invloed langer te laten duren.

"Het aanpassingsvermogen van de zwakzinnigen is moeilijk, vooral aan de maatschappelijke toestanden. We moeten dus zoo lang mogelijk de kinderen onder onze hoede nemen. We moeten verhinderen, dat ze aan verleiding bloot staan, dat ze zich op verkeerde paden begeven. Daaruit volgt, dat ze langer dan andere 
kinderen onder deskundig toezicht moeten blijven. De algemeene gedachte is: ze hebben minder aanpassingsvermogen en dus hebben ze meer bescherming noodig. Dus zoo lang mogelijk onder de leiding der onderwijzers. ${ }^{522}$

Pier de Boer verzette zich, anders dan in 1925 bij de discussie in Amsterdam over de werkinrichting voor imbecillen ${ }^{523}$, tegen deze gedachte. Hij vond dat zo het aanpassingvermogen van oud-leerlingen aan de maatschappij niet kon worden ontwikkeld. Dat kon volgens hem alleen door hen onder stevige leiding de confrontatie met de maatschappij aan te laten gaan.

"We moeten de kinderen geschikt maken voor leiding. Ze moeten aanpassingsvermogen krijgen en dat krijgen ze niet, als ze niet met de maatschappij in aanraking komen. Houden wij ze zoo lang mogelijk buiten de maatschappij, dan maken we ze niet sterk voor hun later leven. Er zijn bezwaren, dat weet ik wel, maar we maken ze niet beter door ze uit hun milieu te halen, want ze komen er later weer in. Juist in hun milieu moeten we de kinderen sterker maken. Dus moeten we invloed op het milieu gaan uitoefenen. ${ }^{524}$

P.H. Schreuder, voorzitter van O\&A en schoolhoofd in Den Haag, sloot zich bij de mening van De Boer aan.

"Wanneer er hier bedoeld wordt leiding der onderwijzers, dan wil dat voor mij zeggen: onderwijzen. De heeren Vos en Leeflang bedoelen natuurlijk: oppassen. En daarvoor moeten, als het noodig is andere krachten komen. ${ }^{.525}$

De vergadering steunde in meerderheid Schreuder en De Boer. De poging van Vos en Leeflang om de invloed van het onderwijs op de zorg voor oud-leerlingen van het BLO te verlengen mislukte. ${ }^{526}$ Wel stelde de vergadering vast, dat er meer aandacht besteed moest worden aan de overgang van school naar maatschappij. Er werd besloten om een commissie in te stellen die dit vraagstuk moest bestuderen en met voorstellen ter verbetering moest komen. ${ }^{527}$ Tot leden van de commissie werden P.H. Schreuder, P. de Boer en de Haarlemse BLO-onderwijzer C. Visser benoemd.

$\mathrm{Zij}$ vonden het in hun rapportage, die in de loop van 1928 verscheen in het Tijdschrift voor Buitengewoon Onderwijs, vooral belangrijk dat er binnen het BLO meer aandacht werd besteed aan het arbeidsgeschikt maken van de leerlingen. Dat kon volgens de commissie door aan de jongens meer handenarbeid te geven en arbeidsonderwijs te introduceren, dat hen moest laten wennen aan het verrichten van regelmatige arbeid. ${ }^{528}$ Voor meisjes stelde men oefening in huishoudelijke arbeid voor, omdat de meesten van hen daarin terecht zouden komen, thuis of in loondienst. Voor hen zouden er speciale huishoudklassen moeten komen. ${ }^{529}$

Deze aanbevelingen werden door de ledenvergadering van O\&A overgenomen, evenals de stelling, dat de nazorg zich moest ontwikkelen tot een aparte tak van dienst, 'van maatschappelijk-paedagogischen aard. ${ }^{530}$ Het werd duidelijk dat ook binnen het BLO het besef groeide dat nazorg dan wel het vervolg was van het onderwijs, maar er geen verlengstuk van vormde.

Nazorg werd door het BLO steeds meer erkend als een zelfstandige hulpvorm, die vanuit haar specifieke ervaring en deskundigheid invloed kon hebben op de invulling van het onderwijs aan de scholen voor BLO. 


\subsection{Onderling contact van nazorgwerkers}

Nazorgwerkers hadden gedurende de jaren twintig regelmatig contact met elkaar. Dat contact was echter niet formeel georganiseerd. Men bezocht elkaars werkinrichtingen, kwam elkaar tegen op congressen en vergaderingen van andere organisaties en publiceerde over de nazorg in de bladen voor BLO. Maar een eigen organisatie waar men elkaar uitsluitend in het kader van de nazorg kon ontmoeten, ontbrak.

Naarmate de tijd vorderde gingen veel nazorgwerkers de behoefte voelen om op meer geregelde basis en alleen in het kader van de nazorg bijeen te komen. Wepster bracht dat in 1928 op het AVO-congres duidelijk onder woorden:

"Tenslotte is het zeer gewenscht, dat de besturen en leiders der Werkinrichtingen niet los naast elkaar blijven arbeiden. Contact is noodzakelijk. Verwisseling van denkbeelden, samenwerking bij het inkoopen van grondstoffen en wellicht ook bij den verkoop der vervaardigde producten kan van groot belang zijn. ${ }^{.531}$

In de jaren twintig zou het niet tot een dergelijke samenwerking komen. Wel werd duidelijk dat er behoefte bestond aan een eigen landelijke nazorgorganisatie. 


\section{Tegen de verdrukking in \\ 1931-1940}

"Als een ondermaatse trekhond voor een wagentje wordt gezet, als een sleperspaard voor een te zware vracht wordt gespannen, zijn de inspecteurs van de Vereniging voor Dierenbescherming er bij, om voor het stomme dier in de bres te springen. Maar als onze ondermaatse leerlingen in het gareel worden gezet, is er helaas nog overreding nodig om te bewerken dat ze worden uitgespannen..."

G. J. van der Ploeg, Over onderwijs aan eenvoudigen van geest. $^{532}$

In dit hoofdstuk ga ik in op de nazorg gedurende de jaren dertig. Deze periode werd getekend door de zware economische crisis, die Nederland en de gehele verdere wereld teisterde. In de eerste paragraaf zal ik kort op de maatschappelijke omstandigheden ingaan. In de tweede paragraaf behandel ik de ontwikkeling van de opvattingen over zwakzinnigheid bij de verschillende werksoorten waarmee de nazorg veel te maken had. Ook ga ik hier in op de discussie die in de jaren dertig werd gevoerd over de samenhang tussen zwakzinnigheid en criminaliteit. Vervolgens bespreek ik de samenwerking die aan het begin van de jaren dertig bij de nazorg ontstond en daarna de ontwikkeling van de relaties tussen de nazorg en aanverwante hulpvormen als BLO, psychiatrie, arbeidsvoorziening en beroepskeuze. Ik sluit af met de inhoudelijke en praktische ontwikkelingen binnen de nazorg zelf.

In dit hoofdstuk komen alle onderzoeksvragen die ik in de inleiding heb gesteld in meer of mindere mate aan de orde.

\subsection{Maatschappelijke ontwikkelingen}

Het hele maatschappelijke leven in de jaren dertig werd beheerst door de gevolgen van de ineenstorting van de NewYorkse effectenbeurs in 1929. De wereldwijde economische crisis die hieruit volgde leidde tot een aanzienlijke terugval van de internationale handel. Voor Nederland betekende dat onder andere dat in 1933 de productie van consumptieartikelen, vergeleken met 1929, met een kwart was gedaald. ${ }^{533}$ Hierdoor was de werkloosheid in het land aanzienlijk toegenomen. Deze bedroeg, op een bevolking van 8,5 miljoen mensen in juni 193047.400 personen. De werkloosheid steeg tot 398.000 in januari 1933, om aan het begin van 1936 een hoogtepunt te bereiken, toen 475.900 personen als werkzoekend stonden geregistreerd. Daarna zette een langzame daling in, met in augustus 1939 nog 243.700 geregistreerde werklozen. ${ }^{534}$

De reactie van de toenmalige regering was er een van aanpassen en de broekriem aanhalen. De opeenvolgende kabinetten onder minister-president Colijn, die tussen 1933 en 1939 het land regeerden, bleven gedurende deze periode een politiek van financiële inkrimping voeren. Gevolg hiervan was, dat het economisch herstel in Nederland aanzienlijk langzamer op gang kwam dan in de rest van de 
westerse wereld. Als de industriële productie in de gehele wereld van het jaar 1929 op 100 wordt gesteld, dan bedroeg die productie op het dieptepunt van de crisis in 1932 voor de gehele wereld 63 . In 1936 was dat cijfer wereldwijd alweer gestegen tot 96. Voor Nederland lag het dieptepunt van de crisis ook in 1932, toen de industriële productie in vergelijking tot 1929 was gedaald tot 62, maar het herstel ging veel langzamer dan in de rest van de wereld. In 1936 was het indexcijfer voor de industriële productie slechts tot 72 gestegen. ${ }^{535}$ Pas na de devaluatie van de gulden in 1936, die de uitvoer van Nederlandse producten naar het buitenland goedkoper maakte, kwam de economie weer op gang, drie jaar later dan in de omringende landen.

De crisis had voor de gemeenten in Nederland ernstige gevolgen. Zij werden enerzijds geconfronteerd met een verhoging van de kosten van onder andere de zorg voor werklozen. Aan de andere kant daalden de inkomsten, zowel door de bezuinigingen van de regering op het gemeentefonds ${ }^{536}$ als door een daling van de opbrengst van belastingen en heffingen vanwege de dalende koopkracht van de bevolking. Gemeenten moesten vaak ingrijpend bezuinigen en stonden daardoor open voor elke maatregel die tot een vermindering van uitgaven zou kunnen leiden.

\subsection{Opvattingen over zwakzinnigen}

De tegenstellingen in opvattingen over zwakzinnigen bestonden spitsten zich in de jaren dertig, net als de maatschappelijke verhoudingen, toe. Voorstanders van eugenetische maatregelen, door alle gezindten heen, brachten hun mening vaker en met meer kracht naar voren en leken, door ontwikkelingen in de ons omringende landen, het tij mee te hebben.

Tegelijkertijd werd in de jaren dertig voor het eerst de centrale rol van de erfelijkheid bij het ontstaan van zwakzinnigheid expliciet in twijfel getrokken. De eerste onderzoeken naar dit verband, die in deze periode werden gehouden, leken uit te wijzen dat die rol veel kleiner was dan tot dan toe gedacht. Ging men er in de jaren twintig nog van uit, dat een slechte erfelijke aanleg kon worden gecompenseerd door een goede sociale omgeving, in de jaren dertig werd voor het eerst de mogelijkheid geopperd, dat het vooral de sociale omgeving was die bepalend was voor het ontstaan van maatschappelijk onaanvaardbaar gedrag.

In de westerse wereld als geheel werd gedurende de jaren dertig volop geëxperimenteerd met maatregelen die de voorplanting van zwakzinnigen en andere geestelijk afwijkenden moesten voorkomen. In veel staten van de V.S., in alle Scandinavische landen en in verschillende Oost-Europese landen werden wetten aangenomen, die het mogelijk maakten om in de voortplanting van ongewenste bevolkingsgroepen in te grijpen. ${ }^{537}$ Voor Nederland waren vooral de ontwikkelingen op dit gebied in twee landen van belang. Allereerst was dat Duitsland, het grootste buurland, waar in 1934 sterilisatie op eugenetische en rashygiënische gronden voor bepaalde groepen verplicht was gesteld. Verder ging het om Denemarken, waar onder een sociaal-democratische regering vanaf 1929 op sociale indicaties mensen gesteriliseerd konden worden. Voor beide landen bestond in de vakliteratuur bijzondere aandacht. 


\subsubsection{BLO en zwakzinnigheid}

In de jaren dertig liepen onder de betrokkenen bij het BLO de opvattingen over de aard van zwakzinnigheid verder uit elkaar. Er konden twee stromingen worden onderscheiden. Eén stroming hield vast aan de negatieve beelden die er van zwakzinnigheid bestonden, bleef grote waarde toekennen aan de erfelijkheid bij het ontstaan van zwakzinnigheid en wilde ingrijpen in de voortplanting van zwakzinnigen niet uitsluiten. Deze eugenetisch getinte stroming bestond vooral uit medici. Aan de andere kant bestond een stroming die de risico's van zwakzinnigheid en zwakzinnigen voor de maatschappij enigszins relativeerde en het ingrijpen in de voortplanting van zwakzinnigen volstrekt afwees. De meeste aanhangers hiervan waren onderwijzers en pedagogen.

Een belangrijke katalysator voor het uiteengroeien van de meningen over zwakzinnigheid werd gevormd door de ontwikkelingen in Duitsland. Hier was in januari 1933 een nationaal-socialistische regering aan de macht gekomen. Deze begon al in haar eerste jaar wetgeving voor te bereiden die voortplanting van ongewenste bevolkingsgroepen moest tegengaan. Binnen BLO-kringen in Nederland volgde men deze ontwikkelingen met angst en beven. Duitsland had tot dan toe voor het BLO op vakinhoudelijk gebied als voorbeeld gediend, men was bang dat die rol door de nationaal-socialistische machtsovername zou wegvallen. In augustus 1933 verscheen een bezorgd artikel in het Tijdschrift voor Buitengewoon Onderwijs.

"Bij een dergelijke geestelike instelling van de autoriteiten is het begrijpelik, dat de Duitse kollega's vrezen, dat hun moeilik opgebouwde organisatie van het buitengewoon onderwijs, gevaar loopt niet intakt te blijven. ${ }^{.538}$

In november 1933 werd in hetzelfde blad een artikel uit het Duitse BLO-tijdschrift Die Hilfsschule aangehaald, waaruit duidelijk werd dat de doelstellingen van het Duitse BLO fundamenteel aan het verschuiven waren. Aandacht voor het individu had niet langer de prioriteit, de 'volksgemeenschap' stond voortaan centraal.

"De geneesopvoeding heeft niet in de eerste plaats waarde voor de opvoedeling en mag in geen geval vrucht van Christelike of algemeen menselike barmhartigheid zijn, maar is voor volksgezondheid, volkswelvaart en voor de toekomst van het volk van geweldige betekenis, daar zijn of niet-zijn van het volk mede sterk door haar bepaald wordt." ${ }^{539}$

Hoe ver de nieuwe machthebbers bereid waren te gaan bleek aan het einde van 1933, toen de teksten van het Gesetz zur Verhütung erbkranken Nachwuchses beschikbaar kwamen. In deze eugenetisch getinte wet, die per 1 januari 1934 van kracht zou worden, werd sterilisatie verplicht gesteld voor lijders aan ziekten waarvan werd verondersteld dat zij een erfelijk karakter droegen. Het ging daarbij om zwakzinnigheid, epilepsie, schizofrenie, blindheid en doofheid. Artsen werden voortaan verplicht om van zulke gevallen onder hun patiënten melding te maken. Speciaal daartoe aangestelde ambtenaren moesten vervolgens ervoor zorgen, zonodig onder dwang, dat de betrokken personen onvruchtbaar gemaakt werden. ${ }^{540}$ In het Tijdschrift voor Buitengewoon Onderwijs van januari 1934 werd er zakelijk verslag van gedaan: 
"Op 1 Januari (1934, LB) treden de sterilisatiewetten aldaar in werking. In het gehele rijk zullen daarvoor 1700 rechtslichamen nodig zijn, terwijl het aantal te steriliseren personen op 400.000 wordt geschat. De kosten er van zullen vele millioenen bedragen. Men hoopt, dat deze geleidelik weer zullen worden teruggewonnen door uitsparing van verplegingskosten in de toekomst. ${ }^{n 41}$

Later in de jaren dertig werd duidelijk, dat het hierbij niet zou blijven en dat de groep te steriliseren personen uitgebreid zou kunnen worden, zoals een artikel in het Tijdschrift voor Buitengewoon Onderwijs uit mei 1936 meldde:

'Die deutsche Sonderschule' nam in het eerste nummer van de tweede jaargang een artikel op van Dr. J. Gottschick, assistent van het rassen-biologisch instituut te Hamburg, waarin de wenselijkheid van onvruchtbaarmaking voor alle leerlingen der buitengewone scholen wordt uitgesproken, daar deze in hoge mate de kwaliteit der nakomelingschap kunnen beïnvloeden." 542

De Duitse vakorganisaties in het buitengewoon onderwijs werden in 1934 gedwongen opgenomen in de nationaal-socialistische onderwijzersbond. In de wetenschap kreeg eugenetisch onderzoek ruim baan. De resultaten hiervan kwamen aan het einde van de jaren dertig voor Nederland beschikbaar. Ze werden in 1939 uitgebreid in het Tijdschrift voor Buitengewoon Onderwijs besproken. ${ }^{543}$

In Nederland trok ook de Deense wetgeving met betrekking tot de behandeling van zwakzinnigen de aandacht. In Denemarken had men voor het model van segregatie gekozen. De meeste zwakzinnigen waren in gestichten ondergebracht. De moeilijkste gevallen, mensen met een neiging tot vagebondage of met een geschiedenis van seksuele misdrijven, konden op twee eilandjes, Livö en Sprogö, naar sekse gescheiden worden geïsoleerd. In de zwakzinnigenwet, die in 1929 in werking trad en in 1934 werd aangepast, was sterilisatie van zwakzinnigen mogelijk. Dat gebeurde niet alleen op eugenetische gronden, zoals in Duitsland, maar ook op sociale indicaties, als voorwaarde voor ontslag uit een inrichting van patiënten die niet in staat werden geacht om kinderen op te voeden of door eigen arbeid een gezin te onderhouden. ${ }^{544}$

Vooral tegen de Duitse wetgeving kwam in het Nederlandse BLO verzet op gang, allereerst vanuit confessionele hoek. In september 1933 deed een Boxtelse BLO-onderwijzer, aangeduid als frater M. Ph. in het Tijdschrift voor R.K. BLO een oproep om tegen de sterilisatiewet te protesteren.

" En vooral aan ons, Katholieke verzorgers en opvoeders van het achterlijke kind, past het, dunkt me, op de eerste plaats, om publiek uiting te geven aan onze verontwaardiging over zulk een immoreele en door de Kerk veroordeelde wetgeving, als de sterilisatiewet is, die zich juist richt tegen de lotgenooten van de aan ons toevertrouwde jeugd in het naburige Duitsche Rijk.

Zou een algemeen en officieel protest, bijv. van onze Bond, nu niet gewenscht zijn?" 545

Bij dit katholieke protest speelde niet zozeer anti-eugenetische gevoelens een rol, alswel een diepe afkeer van het ingrijpen in de menselijke voortplanting, dat op religieuze gronden werd verworpen. Paus Pius XI had dat duidelijk gesteld in de encycliek Casti Connubii uit $19300^{546}$ In een verslag van de R.K. Stichting Zwakzinnigenzorg te Maastricht werd dat op deze manier verwoord: 
" En toch moet sterilisatie, zooals men die voor zwakzinnigen wil: om het eugenetische motief: voorkoming van een minderwaardig nageslacht; om het sociaal-economische motief: vermindering van de lasten, die het bestaan van zwakzinnigen aan de maatschappij oplegt, absoluut worden afgeraden. Waarom? Omdat bovenbedoelde sterilisatie in strijd is met de natuurwet en daarom verkeerd. Ook om een goed doel te bereiken mogen geen verkeerde middelen gebruikt worden." 547

Anderzijds voelden een aantal betrokkenen bij het R.K. BLO zich aangetrokken tot het eugenetisch gedachtegoed en maakten zich in deze kring vooral artsen zorgen over de veronderstelde afname van de kwaliteit van de Nederlandse bevolking. Zo stelde J.H.M. Koenen, die in 1933 in opdracht van de provincie Noord-Brabant een onderzoek publiceerde naar het vóórkomen van zwakzinnigheid bij kinderen, dat het aantal zwakzinnigen ten opzichte van de beter begaafden aan het toenemen was:

"Ziedaar een nieuw maatschappelijk kwaad waartoe zwakzinnigheid evenzeer leidt als tot armoede, krotwoningen, misdaad, alcoholisme en prostitutie, doch dat in zijn gevolgen voor onze samenleving noodlottiger is dan al die andere euvelen te samen. ${ }^{548}$

Katholieke eugenetici konden echter, door het standpunt van de paus, alleen pleiten voor positieve eugenetische maatregelen, het stimuleren van de voortplanting van de beter begaafden.

Vanuit protestants-christelijke hoek werd ook geprotesteerd tegen de Duitse sterilisatiewetten. ${ }^{549}$ Men beschouwde in deze kring sterilisatie als heidens en waarschuwde zelfs voor een 'paganisering' van de samenleving. ${ }^{550}$ In de houding ten opzichte van zwakzinnigen werd hier vooral de nadruk gelegd op de noodzaak van barmhartigheid en hulpverlening:
"Als Christenen zijn we verplicht onze waarschuwende stem te laten horen als we zien, dat de dwaze mens in zijn hoogmoed wijzer wil zijn dan de Schepper en zich in Zijn plaats wil stellen. Het is echter geheel in overeenstemming met de leer van de Christus, bij al de ellende in de wereld, barmhartigheid te betonen aan onze lijdende medeburgers. Bovendien is ook de maatschappij hier het meest mee gebaat." ${ }^{551}$

Van de betrokkenen bij het BLO die bij O\&A waren aangesloten en die ik zou willen aanduiden als de 'algemenen', in hoofdzaak liberalen en sociaaldemocraten, verwierpen de meesten de Duitse wetgeving, al werd er soms wat lauw op de ontwikkelingen gereageerd. Zo zag P.H. Schreuder, de voorzitter van de vereniging, toen hij op de terugreis van een congres in Hongarije in 1934 door Duitsland kwam, niet veel negatiefs:

"Vergeleken met den indruk, welke ik in 't voorjaar van 1933 kreeg, meen ik te
mogen zeggen, dat de zaak niet kwaad verloopt."

Hij zag zelfs voordelen in de nationaal socialistische hervormingen, in de zin dat nu alle organisaties die zich met buitengewoon onderwijs bezighielden, gedwongen werden samen te werken en dat die samenwerking goed was voor het buitengewoon onderwijs als geheel. ${ }^{553}$

Binnen O\&A liepen de meningen over zwakzinnigheid uit elkaar. Ook hier 
valt, net als bij de katholieken, een onderscheid op tussen onderwijzers en artsen. Mensen met een pedagogische achtergrond wezen over het algemeen het eugenetische gedachtegoed af. Een deel van hen probeerde door middel van onderzoek aan te tonen dat het eugenetisch denken over zwakzinnigen deels op legenden berustte. Een ander deel, dat vooral uit mensen met een medische achtergrond bestond, raakte steeds meer overtuigd van de juistheid van de eugenetiek. Het wees maatregelen die erop gericht waren de voortplanting van zwakzinnigen te voorkomen niet principieel af en zou in de loop van de jaren dertig steeds radicaler van opvatting worden.

Belangrijkste vertegenwoordigers van de laatste stroming waren de liberaal A. van Voorthuijsen, de inspecteur van het BLO en de sociaal-democraat D. Herderschêe, schoolarts bij het Amsterdamse BLO. Beiden waren in de jaren dertig veelschrijvers in de tijdschriften voor BLO en Herderschêe gold, als schrijver van het standaardwerk Achterlijke Kinderen, zelfs als dé deskundige op het gebied van zwakzinnigheid in Nederland. ${ }^{554}$ Aan het begin van de jaren dertig wezen beiden nog maatregelen als segregatie en sterilisatie, enkel op grond van het feit dat iemand zwakzinnig was, af. In de loop van de jaren is bij beiden echter een radicalisering waar te nemen, die ermee eindigde dat ze in 1938 allebei lid waren van de redactie van het blad Afkomst en Toekomst ${ }^{55}$, het orgaan van de Nederlandse Eugenetische Federatie.

De grootste bron van zorg voor beiden werd gevormd door de debielen. Hun lichte zwakzinnigheid leidde ertoe, dat er naast hun geringere intellectuele begaafdheid ook een complex aan andere verschijnselen een rol speelde in hun gedrag, wat hen tot een groot risico voor de maatschappij maakte.

"Zij veroorzaken, doordat zij naast hun intelligentie-effect vaak ook nog morele gebreken vertonen, grote moeilikheden in de samenleving ${ }^{\text {"556 }}$

In de visie van Herderschêe leidde dit complex aan bijkomende verschijnselen van lichte zwakzinnigheid tot een heel bijzondere vorm van armoede, het pauperisme. Daarmee doelde hij op de allerlaagste sociale klasse in de maatschappij

'... de groep der chronische werkelooze 'stempelaars', tot de bewoners van de wijken der 'ontoelaatbare' gezinnen enzovoort. ${ }^{.557}$

Bij hen speelde een complex aan moeilijkheden, waarbij armoede, alcoholisme, prostitutie, kinderverwaarlozing, geestelijke afwijkingen en misdaad een gevaarlijk mengsel vormden. Herderschêe noemde hen de social problem group. ${ }^{558} \mathrm{Hij}$ maakte zich grote zorgen over hun toenemende invloed op de samenleving, onder andere omdat de leden van deze groep zich sneller zouden voortplanten dan anderen. ${ }^{559}$ Hij betreurde het dan ook, dat allerlei ziekten als cholera, pokken en tyfus, die vroeger voor een grote sterfte onder de leden van de social problem group hadden gezorgd, door de vooruitgang van de medische wetenschap verdwenen waren. ${ }^{560}$ Hij vond, dat de intellectueel beter begaafden erop moesten letten, dat ze uiteindelijk niet de minderheid zouden gaan vormen:

"... de normalen hebben ervoor te waken, dat het onkruid het goede gewas niet verstikke." 561

Daarom stelde hij in 1934 voor om vooral de probleemgevallen onder de zwakzin- 
nigen harder aan te pakken dan tot dan toe in Nederland gebruikelijk was.

"Misschien zou men moeten beginnen met wat royaler te zijn met het opnemen in internaten van de zoo zwaar belaste debiele psychopathen en der debielen uit zeer ongunstige gezinnen, uit 'the social problem group', het allerarmste deel der bevolking, de voedingsbodem van zwakzinnigheid, vagebondage, misdaden, prostitutie en alcoholisme., ${ }^{562}$

Drie jaar later, in 1937, ging hij een stukje verder en vond dat er strengere maatregelen tegen deze groep nodig waren, vooral segregatie en eventueel ook sterilisatie. ${ }^{563}$

Van Voorthuijsen, de inspecteur van het BLO, vreesde niet zozeer de toename van het aantal zwakzinnigen. Veel meer was hij bang voor wat hij zag als de gevolgen van zwakzinnigheid.

"Men heeft hier te doen met families, die erfelijk zijn belast met laagstaande verstandelijke vermogens en als gevolg daarvan op een lagen trap op den maatschappelijken ladder zijn blijven staan. Er is ten opzichte van het hier bedoelde deel der bevolking alle reden om een nauw verband aan te nemen tusschen zwakzinnigheid eenerzijds en pauperisme, werkloosheid, bedelarij, misschien zelfs prostitutie en misdaad anderzijds. Gaat men één stap verder dan is het bedoelde verband te zien als een oorzakelijk verband. M.a.w. het is zeer waarschijnlijk dat zwakzinnigheid en de daarmee gepaard gaande ongeschiktheid om zich aan de maatschappij aan te passen en op eigen beenen te staan als de voornaamste oorzaak moet worden beschouwd van de groote sociale nooden. $^{n 564}$

Van Voorthuijsen zag zwakzinnigheid als de oorzaak van armoede en bijbehorende problemen. Daarom wilde hij, dat de zorg voor zwakzinnigen actief ter hand zou worden genomen. Hij vond,

"...dat onze houding tegenover de zwakzinnigen volstrekt niet te passief moet zijn. Door toezicht en contrôle kan alleen goed werk worden verricht, wanneer alles in het werk wordt gesteld om den zwakzinnigen aan doelmatigen arbeid te helpen en wanneer daarbij rekening wordt gehouden met de mogelijkheden, die in den zwakzinnigen sluimeren." ${ }^{565}$

Hij wilde een zwakzinnigenzorg die onderling nauw samenhing en zwakzinnigen van de wieg tot het graf zou volgen, om te voorkomen dat ze tot een bedreiging voor de samenleving zouden uitgroeien. Daarom pleitte hij voor nauwe samenwerking tussen medici en pedagogen. De zwakzinnigenzorg zag hij nadrukkelijk als een onderdeel van de geestelijke gezondheidszorg.

Langzamerhand, in de loop van de jaren dertig, schoof Van Voorthuijsen in zijn mening over het voorkómen van voortplanting van zwakzinnigen steeds meer in de richting van de voorstanders van eugenetische maatregelen.

"Tegen het middel van segregatie - het gescheiden houden der sexen - valt niet veel in te brengen. Aan de sterilisatie - de onvruchtbaarmaking door een operatie - zijn wij in Nederland nog niet toe."

Ook ging hij, net als Herderschêe, steeds meer geloven in de legende van de snelle voortplanting van zwakzinnigen. 
"Hier komt nog bij, dat elke beschaving een gering aantal kinderen meebrengt in de gezinnen der klassen, die de beste mannen en vrouwen levert, terwijl in de klassen met groote zorgeloosheid en met gering verantwoordelijkheidsbesef groote gezinnen voorkomen. Steeds is een onderste laag te onderscheiden, waarin hooge vruchtbaarheid gepaard gaat met een groote veelvuldigheid van zwakzinnigheid en psychopatie." ${ }^{567}$

In 1936 maakte hij een studiereis naar Denemarken, waar hij het daar gebruikte stelsel van segregatie en sociaal geïndiceerde sterilisatie bestudeerde en positief in het Tijdschrift voor Buitengewoon Onderwijs beschreef. ${ }^{568}$ Hij werd tevens een pleitbezorger van de positieve eugenese:

"De vraag, welke ons de grootste moeilijkheid geeft, doch waarop het ten slotte het meest aankomt, kan aldus worden geformuleerd: moet de hulp aan misdeelden, zoals wij deze thans kennen, worden aangevuld met de maatregelen der zogenaamde positieve eugenese? ? $^{569}$

En uiteindelijk wees hij zélf sterilisatie op eugenetische gronden niet langer af, maar stelde, dat in Nederland daarvoor het juiste klimaat nog niet bestond. ${ }^{570}$

Tegenover de invloedrijke meningen van Herderschêe en Van Voorthuijsen stonden de opinies van een aantal onderwijzers die minder veelvuldig de pen ter hand namen. Zij wezen erop, zoals bijvoorbeeld J. Polderman in het juninummer 1934 van het Tijdschrift voor Buitengewoon Onderwijs, dat sterilisatie als middel om zwakzinnigheid tegen te gaan niet effectief was:

"Het systematies steriliseren van zwakzinnigen zal niet het beoogde doel hebben. Nog altijd zullen toevalligheiden oorzaak zijn, dat er zwakzinnigen zijn. Het volledig ontmannen is een barbaarsheid, die wel voor grote misdadigers als straf kan verklaard worden, maar die toegepast op onschuldige minderbegaafde of niet begaafde wezens ons doet terugdenken aan de Spartaanse wetgever, Lycurgus, die de oude Spartanen beval hun misgeboorten van een hoge rots in de afgrond te werpen. ${ }^{\text {"571 }}$

Zij zagen speciaal onderwijs voor zwakzinnigen, gevolgd door speciale zorg in de maatschappij, als het beste en meest effectieve middel om het maatschappelijke risico dat zwakzinnigen vormden zo veel mogelijk te beperken.

"Het B.O. is een noodzakelikheid, een verdedigingsmiddel van de maatschappij tegen haar eigen minderwaardige elementen. Een goed ingericht B.O. met een volledige nazorg kan van haar leerlingen nog goed bruikbare leden der samenleving maken, die in hun kleine kring meer goedheid en rustige familiezin kunnen doen heersen, dan menig begaafd individu, dat eerder door zijn daden en levenswijze verdiende, dat zijn ouders destijds gelubd werden." ${ }^{572}$

In 1933 was in het Tijdschrift voor Buitengewoon Onderwijs een artikel verschenen, een overdruk uit het Tijdschrift voor Armwezen, Maatschappelijke Zorg en Kinderbescherming, waarin de Engelsman F. Douglas Turner kanttekeningen plaatste bij de conclusies, die onder andere in Nederland werden getrokken uit het onderzoek, dat de Wood-commssie in Engeland in opdracht van de regering had uitgevoerd naar zwakzinnigheid en zwakzinnigen. Hij kon daar met enig gezag over spreken, want hij had zelf deel van die commissie uitgemaakt. ${ }^{573}$

Het meest aangehaalde onderdeel van het rapport van de Wood-commissie 
was een onderzoek van E.O. Lewis, waaruit zou blijken dat het aantal zwakzinnigen in Groot-Brittannië, in vergelijking met een onderzoek naar hun aantal een twintigtal jaar daarvoor, was toegenomen. Dit onderzoek werd vaak gebruikt als bewijs dat het aantal zwakzinnigen in de westerse wereld zou toenemen. ${ }^{574}$

Douglas Turner stelde, dat het onderzoek van Lewis niet vergeleken mocht worden met het eerdere onderzoek, omdat beide onderzoeken een verschillende definitie van zwakzinnigheid hanteerden en er dus appels met peren werden vergeleken. Hij was het ook niet eens met de stelling, dat zwakzinnigen zich sneller zouden voortplanten dan intellectueel beter begaafden.

"De mening omtrent de stortvloed van kinderen van een pauper-type, die zwakzinnigen worden ondersteld ter wereld te brengen, is op uitgebreide schaal verbreid, niet op grond van betrouwbaar onderzoek, maar op grond van verzamelingen van de geschiedenis van bepaalde families, en wel bepaaldelik gebaseerd op zekere welbekende pogingen van Noord-Amerikaanse Staten (onder andere het onderzoek naar de familie Kallikak door Goddard, LB). ledereen die zich met zwakzinnigen bezig houdt, kan gevallen vermelden van slechte families, maar op zichzelf bewijzen zij niets en de meerbekende gevallen uit Noord-Amerika zijn volkomen onbetrouwbaar. ${ }^{.575}$

Onderzoek dat wél betrouwbaar zou zijn en dat door de nazorg van het BLO in Birmingham was uitgevoerd, gaf een indicatie voor het tegendeel: zwakzinnigen zouden zich juist minder snel voortplanten dan normaal begaafden:

"Deze schijnen aan te tonen dat de kinderen van deze scholen, volwassen geworden een buitengewoon klein aantal kinderen hebben, zo klein inderdaad, dat hun gezamenlik aantal niet zo groot is als het aantal der ouders. Dit onderzoek schijnt aan te tonen dat families van zwakzinnigen uitsterven." ${ }^{576}$

Ook stelde hij dat zwakzinnigen veel minder vaak dan werd verondersteld maatschappelijk ontspoorden.

"Een ander deel van deze legende (over zwakzinnigheid, LB) is dat de zwakzinnigen een groot deel van onze misdadigers en prostituées uitmaken. Op dit oogenblik is de grote meerderheid der zwakzinnigen van goed gedrag., ${ }^{577}$

Verder verzette Douglas Turner zich tegen het idee, dat door sterilisatie het mensdom van zwakzinnigheid kon worden bevrijd. Hij vond dat er nader onderzoek moest komen naar relatie tussen erfelijkheid en omgevingsfactoren voordat hierover definitieve uitspraken werden gedaan. ${ }^{578}$

Niet alleen verzette hij zich tegen sterilisatie op eugenetische gronden, ook op grond van sociale indicaties vond hij ingrijpen in de voortplanting van zwakzinnigen onverantwoord. Het aantal zwakzinnigen, dat kinderen kreeg, was volgens Douglas Turner daarvoor te klein. Bovendien wees hij op het gevaar voor de zedelijkheid van zwakzinnige meisjes die ná sterilisatie seksueel actief konden zijn zonder het risico te lopen zwanger te worden. ${ }^{579}$

Het artikel van Douglas Turner lijkt vooral bedoeld te zijn geweest als een reactie op de meer eugenetisch gerichte artikelen die Van Voorthuijsen en Herderschêe in het tijdschrift publiceerden. ${ }^{580}$ Als het de bedoeling was om een reactie los te krijgen, dan mislukte die opzet want het artikel werd door hen volkomen genegeerd. 
lets anders lag dat met een onderzoek dat Fr. Visser, hoofd van de openbare BLO-school in Utrecht, in 1936 deed onder de oud-leerlingen van zijn school. Hij probeerde daarmee aan te tonen, dat zwakzinnigen zich niet sneller voortplantten dan normaal-begaafden. Hij onderzocht in hoeverre oud-leerlingen van zijn school huwden en hoeveel kinderen er uit die huwelijken voortkwamen ${ }^{581} \mathrm{Hij}$ betrok in totaal 292 oud-leerlingen van het BLO die tussen 1908 en 1918 zijn school hadden verlaten bij het onderzoek. Van hen ondervroeg hij er uiteindelijk 194. Als controlegroep gebruikte hij 292 oud-leerlingen van het gewone lager onderwijs in Utrecht, die in dezelfde periode de school hadden verlaten. Van deze groep sprak hij er uiteindelijk $160 .{ }^{582}$

Van de 194 oud-BLO-leerlingen waren er 63 getrouwd, van de 160 oudleerlingen van het gewoon lager onderwijs $103 .{ }^{583}$ De gehuwde oud-BLOleerlingen hadden in totaal 99 kinderen, gemiddeld 1,6 kind per huwelijk. Bij de gehuwde oud-leerlingen van het reguliere onderwijs kwamen in totaal 148 kinderen voor, 1,64 kind per huwelijk. ${ }^{584}$

Vervolgens probeerde Visser te onderzoeken, hoeveel zwakzinnigen er voorkwamen onder de kinderen van gehuwde oud-leerlingen van het BLO. Van deze 99 kinderen waren er 61 té jong om op hun intellectuele capaciteiten onderzocht te worden. Van de 38 kinderen die wél onderzocht konden worden, waren er vijf, met daarbovenop nog twee twijfelgevallen, die voor BLO in aanmerking kwamen of er al onderwijs volgden. ${ }^{585}$

Visser was er van overtuigd dat hij met zijn onderzoek de legende van de snellere voortplanting van zwakzinnigen had ontzenuwd. Allereerst had hij laten zien dat zwakzinnigen veel minder vaak in het huwelijk traden dan intellectueel normaal begaafden en vervolgens dat zwakzinnigen die wél trouwden gemiddeld iets minder kinderen kregen dan normaal begaafden. Het verleidde Visser ertoe, de voorstanders van eugenetische maatregelen rechtstreeks aan te spreken:

"De heer F. Schrijver, gemeentearts te Amsterdam, schrijft in 'Erfelijkheid bij de mens' van October ' 35 : "Niet alleen zien we tegenwoordig de minderwaardigen zich voortplanten, maar als men hun kindertal vergelijkt met dat van volwaardige personen, dan ziet men dat de vruchtbaarheid in het algemeen stijgt, naarmate de sociale waarde afneemt." Wij bevonden dat niet de minderwaardigen zich voortplanten, maar slechts $32.5 \%$. Zoals gezegd constateerden we evenmin meerdere vruchtbaarheid. (...) Hieruit blijkt, dat oud-leerlingen van buitengewone scholen minder kans hebben op een grote nakomelingschap dan normalen. ${ }^{586}$

Hij ging ook in op de sterilisatie op sociale indicatie zoals in Denemarken, waarvan Van Voorthuijsen zo gecharmeerd leek:

"Waar men in Denemarken, zoals Dr. A. v. Voorthuijsen in zijn opstel 'Zwakzinnigenzorg in Denemarken' meedeelt, sterilisatie in hoofdzaak toepast op grond van de sociale overweging, dat de kinderen, welke geboren worden, niet door de ouders kunnen worden grootgebracht, is het ongetwijfeld van belang er de aandacht op te vestigen, dat o.i. tegen de door ons bezochte gezinnen als opvoedings-milieu in grote meerderheid geen ernstige bezwaren naar voren kunnen worden gebracht. Deze opvatting wordt nog versterkt door het feit, dat in hoofdzaak alleen licht-debielen, die getoond hebben door betrouwbaarheid, ijver en plichtsbetrachting zich in de maatschappij te kunnen handhaven, tot het sluiten van een huwelijk was overgegaan.. ${ }^{587}$ 
Ook Herderschêe sprak hij rechtstreeks aan:

"Aan Dr. Herderschêe zouden we willen opmerken, dat de snelle toename (zo daar al sprake van is) van het aantal achterlijke kinderen moeilijk op rekening van de gehuwde zwakzinnigen kan worden gesteld. Van de \pm 300 achterlijke kinderen in schoolleeftijd in Utrecht zijn er 6, waarvan de vader of de moeder zwakzinnig is! $!^{588}$

Maar Herderschêe scheen niet onder de indruk. Hij slaagde er zelfs in om Vissers onderzoek te gebruiken als bewijs voor zijn eigen, meer eugenetisch gerichte standpunten door buitengewoon selectief om te gaan met diens onderzoeksresultaten. Hij negeerde de uitkomsten van het onderzoek van Visser dat oud-leerlingen van het BLO minder vaak huwden dan oud-leerlingen van het regulier lager onderwijs en dat zij, als ze dat dan toch deden, gemiddeld minder kinderen kregen dan 'normalen', maar haalde alleen aan dat als oud-leerlingen van het BLO dan toch kinderen kregen, daaronder méér zwakzinnigen voorkwamen dan gemiddeld.

"Door onze pogingen, om de aanpassing der debielen te vergroten, bereiken wij tevens, dat veel meer dan vroeger de debielen in staat zijn, een gezin te stichten, dus hun ongunstige aanleg te doen voortplanten. Het, zij het ook kleine, onderzoek van $F$. Visser bewees weer, dat het percentage zwakzinnigen onder de kinderen der achterlijken aanzienlijk groter is dan onder de bevolking in het algemeen." 589

De meningen over de rol van de erfelijkheid tegenover de rol van de sociale omgeving zouden in de loop van de jaren dertig steeds meer tegenover elkaar komen te staan. Van enige toenadering tussen beide standpunten was geen sprake. De eugenetiek was in deze periode in Nederland op haar hoogtepunt, zonder enige eugenetische maatregel in de praktijk wettelijk geregeld te krijgen. Aan de andere kant werd er ijverig aan de stoelpoten van het eugenetische gedachtegoed gezaagd door de eerste onderzoeken naar de daadwerkelijke rol van erfelijkheid bij zwakzinnigen.

\subsubsection{Sociale psychiatrie en zwakzinnigheid}

De aandacht binnen de sociale psychiatrie voor zwakzinnigheid speelde zich, net als binnen het BLO, zich vooral af in het krachtenveld tussen eugenetiek en sociale hygiëne. Bij beide groeperingen bestond de overtuiging, dat zwakzinnigen, als onderdeel van de grotere groep van sociaal afwijkenden, een risico voor de samenleving vormden, zoals de katholieke psychiater C.T. Kortenhorst in 1930 duidelijk maakte:

"Een langdurige ervaring heeft uitgewezen, dat zwakzinnige of geesteszwakke kinderen zonder de juiste schoolvorming een last en een gevaar kunnen worden voor zichzelf, voor hun familie en maatschappij. Deze geesteszwakken raken gemakkelijk onder den invloed van kwaadwillende elementen. Vele zakken af naar het heirleger der misdadigers en andere asocialen en voor zoover het meisjes zijn, worden zij spoedig verleid en geven een hoog percentage onder de ongehuwde moeders en prostituées. Een nauwe wisselwerking bestaat er tusschen alcoholisme, verwaarloozing, misdaad, armoede en zwakzinnigheid." 590

Kortenhorst doelde hier op de sociale klasse, die Herderschêe de social problem 
group had genoemd. De problematiek van deze groep zou in de sociale psychiatrie uiteindelijk met de term onmaatschappelijkheid worden samengevat.

Het probleem was voor het eerst in de jaren twintig geconstateerd door organisaties voor sociale woningbouw in de grote steden. Deze kregen te maken met een groep huurders, die hun huis niet volgens algemeen aanvaarde normen bewoonde en de buren overlast bezorgde. $\mathrm{Zij}$ werden aanvankelijk aangeduid als ontoelaatbaren. ${ }^{591}$ In de loop van de jaren twintig werden pogingen ondernomen om het gedrag van deze probleemhuurders te corrigeren. Daarbij werd gekozen voor het middel van segregatie gecombineerd met heropvoeding. In aparte, besloten woonwijkjes moesten zij onder toezicht leren hun woongedrag aan te passen om, als zij zich naar tevredenheid gedroegen, weer in een normale huurwoning te worden teruggeplaatst. ${ }^{592}$

Op grond van de ervaringen die met deze heropvoedingswijken waren opgedaan ontstond aan het einde van de jaren twintig het idee dat de ontoelaatbaren niet alleen een probleem hadden met hun woongedrag, maar met hun maatschappelijk functioneren als geheel. Ze kregen een nieuwe naam, onmaatschappelijken, en hun gedrag werd in verband gebracht met alcoholisme, kinderverwaarlozing, onzedelijkheid en criminaliteit. ${ }^{593}$

De psychiater Arie Querido, die in 1931 F.S. Meijers was opgevolgd als leider van de afdeling Geestelijke Hygiëne van de Amsterdamse GG\&GD, ontwikkelde aan het begin van de jaren dertig een typologie van de onmaatschappelijkheid, aan de hand van een onderzoek dat hij had gedaan onder de bewoners van het Zeeburgerdorp, een van de heropvoedingswijken in Amsterdam. ${ }^{594}$

Hij onderscheidde drie verschillende groepen onder de bewoners van deze wijk. Als eerste de voorwaardelijk maatschappelijken, mensen die door invloeden van buitenaf in armoede waren afgegleden en die daar, als de omstandigheden verbeterden, weer uit zouden kunnen komen. ${ }^{595}$ De tweede groep noemde hij de voorwaardelijk onmaatschappelijken. Van hen was duidelijk dat er zich een of andere geestelijke afwijking voordeed, maar het was niet duidelijk of zij onder betere omstandigheden anders geleefd zouden hebben. ${ }^{596}$ De derde groep waren de onvoorwaardelijk onmaatschappelijken, mensen die onder geen voorwaarde in staat zouden zijn om zich zelfstandig in de maatschappij te handhaven. ${ }^{597}$

Querido onderzocht de tweede groep, de voorwaardelijk onmaatschappelijken, nader. Deze was voor hem het meest interessant, omdat voor deze groep heropvoeding zin kon hebben. Hij omschreef vier geestelijke afwijkingen die onder hen zouden voorkomen en die tot hun maatschappelijk afglijden zouden hebben bijgedragen: dronkenschap, geestesziekte bij één der ouders, geestelijke debiliteit en psychopathische trekken. ${ }^{598}$

In zijn interpretatie van de oorzaken van deze vorm van pauperisme legde Querido de nadruk op de omstandigheden waaronder deze families moesten leven. Hij vond het veel te kort door de bocht om de oorzaken van het paupergedrag direct bij de erfelijkheid te leggen. Hij stelde, dat er eerst eens onderzoek gedaan moest worden naar de vraag, hoe en waarom families tot pauperisme vervielen:

"Het komt mij voor, dat in deze redeneering op zeer lichtvaardige wijze met het begrip erfelijkheid - om van het woord 'ras' maar te zwijgen - wordt omgesprongen en dat de invloed, die levensvoorwaarden en milieu hebben - zoowel op de 
Hij vond dat er nadrukkelijk gekeken moest worden naar de gevolgen van, vaak generaties durende, verwaarlozing en vond, dat de erfelijkheid geen rol hoefde te spelen bij een verklaring voor de toestand waarin veel bewoners van het Zeeburgerdorp zich bevonden:

" Het blijkt dus, dat voor de verklaring van de toestanden, zooals wij die bij de bewoners van het Zeeburgerdorp vinden, erfelijke factoren geen rol behoeven te spelen. Anders gezegd: voor den invloed van deze factoren vinden wij geen bewijs, wel zijn er talrijke aanwijzingen voor den invloed van maatschappelijke omstandigheden." ${ }^{600}$

Binnen de sociale psychiatrie speelde de eugenetiek een minder prominente rol dan binnen het BLO. De opdracht van deze werkvorm was nu juist, gestichtsplaatsingen zoveel mogelijk tegen te gaan en verzorgingsarrangementen te ontwikkelen die psychiatrische patiënten binnen de samenleving zouden kunnen houden. Geen aanlokkelijk perspectief voor eugenetisch geïnteresseerde psychiaters die dan ook vooral in de gestichtspsychiatrie te vinden waren. ${ }^{601}$

\subsubsection{Arbeidsvoorziening en zwakzinnigheid}

De arbeidsvoorziening hield zich in de jaren dertig grotendeels buiten de discussie over oorzaken en aard van zwakzinnigheid. Detiger was de enige in dit werkveld die zich inhoudelijk uitliet over de nationaal-socialistische machtsovername in Duitsland.

"Er gaat weer eens een golf van egoïsme door de wereld. Van individueel en groeps-egoïsme, van nationalisme en rassensaamhorigheid. Dat loopt altijd uit op een soort suggestief zelfbewustzijn, 'dat men niet is gelijk de andere'. De door algemene naastenliefde en algemene menselikheid ingegeven objectieve beoordeling der waarde van 'de andere' raakt er door op de achtergrond.(...) Men verwerpt het sentimentele. En men noemt sentimenteel wat mensenliefde is die uitgaat boven afscheidingen. Men minacht de achterblijvers. Men sluit voortdurend de gelederen. De flinke, de krachtige geeft de tred aan. Nog nooit is de eugenese zo in trek geweest, niet alleen in Duitsland. De rassen-hygiëne wil de soort verbeteren door selectie en het uitwerpen van wat overblifft.

$\mathrm{Er}$ is geen lust en geen tijd om zich bezig te houden met het zwakke. ${ }^{602}$

De inhoudelijke kant van het vraagstuk der onvolwaardige arbeidskrachten werd overgelaten aan de Staatscommissie inzake Onvolwaardige Arbeidskrachten, die in 1929 door de regering was ingesteld naar aanleiding van het AVO-congres van 1928 en die eind 1938 haar rapport uitbracht. Met betrekking tot zwakzinnigheid leunde de Staatscommissie vooral op de kennis die hierover bestond binnen het BLO en de sociale psychiatrie. Zowel Herderschêe als Querido werden door de commissie aangehaald ${ }^{603}$ en als het om de keuze tussen murture of nature ging als oorzaak van zwakzinnigheid nam de commissie een tussenstandpunt in.

"Zij (de commissie, LB) is van oordeel, dat het milieu inwerkt op het met een zekeren aanleg toegeruste individu. Door de samenwerking van beide factoren worden de toestand en de levensloop van het individu bepaald. Het is mogelijk, dat de eigenschappen, die in den aanleg aanwezig zijn, blijven sluimeren of door 
bijzondere maatregelen tot ontwikkeling worden gebracht. Ongetwijfeld zijn aan den invloed van deze maatregelen grenzen gesteld. In geen geval mag echter een fatalistische opvatting van den allesoverheerschenden invloed van den aanleg er toe leiden, dat geen middelen tot verbetering van de levensomstandigheden der zwakzinnigen worden beproefd. ${ }^{" 604}$

De AVO richtte zich vooral op de tewerkstelling van onvolwaardige arbeidskrachten, waartoe ook zwakzinnigen gerekend werden. Om die praktijk te verbeteren, werden deskundigen uit de praktijk gevraagd hierover hun licht te laten schijnen. Zo schreef Pier de Boer een preadvies over de vakopleiding voor zwakzinnigen ten behoeve van de jaarvergadering van de AVO over $1932 .{ }^{605}$ Verder lijkt hier de economische crisis, met alle moeilijkheden die dat meebracht om mensen in werk geplaatst te krijgen, elke diepgaande inhoudelijke meningsuitwisseling in de weg te hebben gestaan. Bij de arbeidsbemiddeling ging de praktijk voor de theorie.

De arbeidsvoorziening als geheel was in 1930 voor het eerst wettelijk en op landelijk niveau geregeld. Het land werd in districten verdeeld en elke gemeente met meer dan 15.000 inwoners werd verplicht om een arbeidsbeurs op te richten. In de kleinere gemeenten kwamen agentschappen. De verantwoordelijkheid voor de arbeidsbemiddeling lag bij de gemeenten. Er kwam een kleine landelijke organisatie die de arbeidsbemiddeling tussen gemeenten in goede banen moest leiden. ${ }^{606}$

\subsubsection{Discussie: zwakzinnigheid en criminaliteit}

Het krachtiger wordende eugenetische geluid in Nederland, de discussie over de zin en onzin van maatregelen om de voortplanting van zwakzinnigen tegen te gaan, het idee dat zwakzinnigheid de oorzaak van armoede en pauperisme was en de economische crisis, die de armoede in Nederland flink had doen toenemen, leidden ertoe dat in de jaren dertig de belangstelling voor de samenhang tussen zwakzinnigheid en criminaliteit groeide.

Een eerste aanzet voor de discussie hierover werd gegeven door het onderzoek naar crimineel gedrag onder oud-leerlingen van het BLO in Den Haag, dat onderdeel uitmaakte van het Haagse nazorgrapport van 1930. De samenstellers van dit rapport hadden onderzocht hoeveel oud-leerlingen van de Haagse scholen voor BLO in contact waren geweest met politie en justitie. Van de 1155 leerlingen die de Haagse scholen voor BLO vanaf het ontstaan in 1901 hadden verlaten, konden de gegevens van 764 van hen worden onderzocht. Uit dit onderzoek bleek, dat van deze 764 oud-leerlingen van het Haagse BLO er 265 ooit in aanraking waren gekomen met de politie, ruim $34 \%$ van de onderzochte personen. ${ }^{607}$ Met deze cijfers wilden de schrijvers van het rapport laten zien, wat er gebeurde als er onvoldoende zorg aan de oud-leerlingen van het BLO werd besteedt. Ze gebruikten de cijfers als argument dat vóór de invoering van nazorg in Den Haag pleitte.

"De enquête bracht duidelijk aan het licht, dat Nazorg noodig is (...); met raad en daad dient steun te worden gegeven, moreele en materieele, aan den oudleerling meestal; vaak ook aan zijn vader of aan zijn moeder; met de werkgevers dient te worden gesproken, met de onderwijzers, die den oud-leerling kennen, overleg." 608

Van Voorthuijsen trok in het verslag van zijn werkzaamheden over 1931 hele andere conclusies. Hij gebruikte het als bewijs voor zijn stelling, dat zwakzinnigen door 
de aard van hun gebrek crimineler waren dan gewone mensen. ${ }^{609}$ Het was voor hem de bevestiging van een idee, dat hij al langer had gehad. In 1930 schreef hij over het verband tussen zwakzinnigheid en criminaliteit het volgende:

"Men heeft hier te doen met families, die erfelijk zijn belast met laagstaande verstandelijke vermogens en als gevolg daarvan op een lagen trap op den maatschappelijken ladder zijn blijven staan. Er is ten opzichte van het hier bedoelde deel der bevolking (de laagste sociale klassen, LB) alle reden om een nauw verband aan te nemen tusschen zwakzinnigheid eenerzijds en pauperisme, werkloosheid, bedelarij, misschien zelfs prostitutie en misdaad anderzijds. ${ }^{610}$

In zijn onderzoek uit 1933 voor de Provinciale Commissie voor Zwakzinnigenzorg in Noord-Brabant over de aard en de omvang van zwakzinnigheid in deze provincie stelde J.H.M. Koenen, als psychiater verbonden aan krankzinnigengesticht 'Huize Voorburgh' in Vught, dat er een positief verband bestond tussen zwakzinnigheid en criminaliteit en dat er zeker zoiets bestond als 'the menace of the feebleminded'. ${ }^{611}$

\begin{abstract}
"Dat er onder de misdadigers vele zwakzinnigen zijn is bekend en begrijpelijk. De zwakzinnige mist geheel of ten deele de intellectuele remmen, welke voor misdaad kunnen behoeden en daarenboven is het geestelijk defect dikwerf niet louter een intelligentiedefect, doch vertoont de zwakzinnige dikwijls ook primair ethische tekortkomingen." ${ }^{.612}$
\end{abstract}

Een zó rechtstreeks verband werd niet door iedereen gelegd. A.H. Fortanier stelde in 1934 in een lezing voor het Leids Criminologisch Instituut dat het met zwakzinnigheid als onderliggende oorzaak van criminaliteit bij kinderen wel meeviel.

"Slechts in een klein deel der gevallen is de aanleg, zich manifesterend in b.v. achterlikheid of psychopaties karakter, als hoofdoorzaak te beschouwen voor de criminele handeling. ${ }^{613}$

Ook binnen de nazorg werd de koppeling tussen zwakzinnigheid en criminaliteit enkele malen aan de orde gesteld. Dat gebeurde aan de hand van de eigen waarneming van nazorgwerkers. In 1934 was Wepster de eerste die het onderwerp wilde bespreken op een vergadering van de Nederlandsche Vereeniging Nazorg Buitengewoon Onderwijs (NVNBO), waarbij hij veronderstelde dat er een verband bestond met de toenemende armoede door de economische crisis.

"Wepster - Dordrecht - is van meening dat de criminaliteit toeneemt. Komt dit door ondervoeding? Van de 160 debielen van zijn school zijn er 110 die door de gemeenschap gevoed en gedeeltelijk gekleed worden. ${ }^{614}$

Inhoudelijk werd er toen niet op het onderwerp ingegaan. Dat gebeurde wél in 1938 , toen Pier de Boer voorstelde om te onderzoeken hoeveel nazorgpupillen in aanraking kwamen met de politie. Dat was vooral bedoeld om tegenwicht te bieden aan het criminaliteitsonderzoek in het Haagse nazorgrapport, dat steeds opnieuw werden aangehaald als bewijs voor de vermeende criminele aanleg van zwakzinnigen. ${ }^{615}$ Andere onderzoeken wezen uit, dat oud-leerlingen van het BLO niet buitengewoon vaker crimineel waren dan hun normaalbegaafde leeftijdsgenoten. ${ }^{616} \mathrm{De}$ Boer had in zijn eigen praktijk de ervaring opgedaan dat de criminaliteit onder zijn pupillen toenam, maar hij had er niet voldoende zicht op. ${ }^{617}$ 
Fr. Visser, hoofd van de openbare school voor BLO in Utrecht, was opnieuw de eerste de er onderzoek naar deed. Hij pakte het grondig aan en begon zijn onderzoeksverslag, dat in het decembernummer 1938 van het Tijdschrift voor Buitengewoon Onderwijs verscheen, met een beknopt overzicht van de recente literatuur over het onderwerp. Cyril Burt, in het boek Geestelijke onvolwaardigheid dat in 1936 in het Nederlands was vertaald, stelde dat $10 \%$ van de kindermisdadigers in Engeland zwakzinnig was. Visser haalde vervolgens een aantal karaktereigenschappen van zwakzinnigen aan die in de literatuur genoemd werden en die bij hen tot criminaliteit zouden kunnen leiden.
"1. Begerigheid met gebrekkige remming en gemis aan overleg van de gevol- gen.
2. Impulsiviteit door overgrote prikkelbaarheid.
3. Suggestibiliteit blijkende uit gemakkelijke verleidbaarheid.
4. Zelfoverschatting, op grond van minderwaardigheidsgevoelens, zich ui- tend in ophakkerij.
5. Gebrek aan energie, waardoor uit gemakzucht misdaden worden ge- pleegd, soms om te ontkomen aan kleine ongemakken, of vervelende op- drachten. ${ }^{.618}$

Vervolgens gaf hij karaktereigenschappen weer, opnieuw uit de literatuur, die bij zwakzinnigen zouden voorkomen en juist niét tot criminaliteit zouden leiden:
"Zwakzinnigen vertonen dikwijls een tekort aan: observatievermogen, inzicht en overleg, fantasie, durf, energie en activiteit. Zullen ze daardoor niet dikwijls op het rechte pad blijven onder omstandigheden, die normalen zouden doen afdwa- len?"619

Visser had 292 oud-leerlingen, die tussen 1908 en 1918 zijn school hadden verlaten, onderzocht op crimineel gedrag. Als controlegroep gebruikte hij 292 oudleerlingen van het reguliere lager onderwijs, die in dezelfde periode van school waren gegaan. ${ }^{620}$

De uitkomsten van zijn onderzoek gaven, anders dan in Den Haag, aan dat het met de criminaliteitscijfers onder oud-leerlingen van het BLO erg meeviel en dat ze zelfs lager waren dan die onder de oud-leerlingen van het reguliere onderwijs.

"Wij vonden dus onder de zwakzinnigen 15, onder de normalen 17 vermeldingen in het vonnissen-register der politie. Beschouwt men het aantal gevallen waarin géén straf werd opgelegd, beschouwt men de aard der misdrijven, dan kan men niet aan de gedachte ontkomen, dat altans hier in Utrecht de misdadigheid dezer oud-I.I. v.e. B.O.L.S. (Buitengewoon Onderwijs Lagere School, LB) geenszins die der normalen overtreft. ${ }^{.621}$

Voor het verschil met het Haagse onderzoek gaf Visser als verklaring dat er in Den Haag ten tijde van het onderzoek geen nazorg had bestaan en dat daardoor de criminaliteit onder oud-leerlingen van het BLO er hoger was geweest. In gemeenten met nazorg, zoals Utrecht, was crimineel gedrag onder oud-leerlingen van het $\mathrm{BLO}$ aanzienlijk lager. ${ }^{622}$

De strafrechtdeskundige M.J.M. van Bemmelen stelde in een lezing in 1939 voor het Leids Criminologisch Instituut dat het onderzoek van Visser niet 
hoefde te kloppen, omdat niet zeker was of er onder de oud-leerlingen van het reguliere onderwijs geen zwakzinnigen voorkwamen.

"Wie garandeert ons, dat onder de groep 'normalen' ook niet zwakzinnigen schuilden. Zij werden immers gesteld tegenover leerlingen van het B.O. en de Boer geeft zelf toe (...) dat het B.O. op het oogenblik nog nergens alle debiele kinderen bereikt. ${ }^{623}$

Van Bemmelen haalde Klootsema weer van stal, die aan het begin van de twintigste eeuw een onlosmakelijk verband tussen zwakzinnigheid en criminaliteit had geconstateerd. Hij had in 1904 gesteld,

“... dat hij nog nooit een misdadig kind had gezien, dat niet, of verwaarloosd of zwakzinnig was en zelden een zwakzinnig kind, dat niet misdadig was., ${ }^{1624}$

De Boer gaf in dezelfde lezingencyclus voor de Leidse criminologen zijn eigen kijk op het verband tussen zwakzinnigheid en criminaliteit. Daarbij gebruikte hij een originele invalshoek. Hij stelde, dat er alleen gevaar voor criminaliteit onder zwakzinnigen bestond als zij werden verwaarloosd, als er niet voldoende zorg aan hen werd besteed.

"Als wij nu terugzien op de zwakzinnige, dan behoeft het geen betoog, dat deze menschenkinderen uiterst gevoelig zullen zijn voor 'verwaarloozing' en dat de gevolgen van deze verwaarloozing schromelijk zullen zijn. ${ }^{625}$

Die gevoeligheid voor verwaarlozing had volgens De Boer te maken met de specifieke karaktereigenschappen waarover zwakzinnigen beschikten. Hij was het in dit opzicht eens met de Duitse pedagoog Scholz:

"Schwachsinn ist mehr als intellectuelle Schwache; er ist Verkümmerung der Gesamtpersönlichkeit". ${ }^{26}$

Hij gebruikte, om de gevolgen van zwakzinnigheid op de persoonlijkheid van degenen die eraan leden uit te leggen, een vergelijking met oogafwijkingen.

"Indien iemand bijziend of vèrziend is en geen bril als correctiemiddel gebruikt, vervagen de beelden, die via het netvlies in het bewustzijn worden vastgelegd; de beelden worden onvollediger, bijzonderheden verdwijnen; het oordeel over wat gezien wordt, wordt onbetrouwbaar; andere ooggebreken (kleurenblindheid) laten bijzondere eigenschappen, die voor normale oogen wel zichtbaar zijn, geheel vervallen. Een betrouwbare beschrijving is op deze wijze niet te verwachten. Op dezelfde wijze, alleen in zijn gevolgen erger, moeten wij ons voorstellen, dat het proces verloopt bij een beschadigd intellect, zooals wij dit zien bij de zwakzinnigen." 627

Het gebrekkig inzicht en oordeel waarover zwakzinnigen beschikten, kon volgens De Boer tot grote problemen in hun maatschappelijk leven leiden.

"Een gevolg van dit gebrekkig inzicht en oordeel is, dat ingewikkelde verhoudingen en zaken, welke door een normaal intellect spelenderwijze worden ontleed, voor hen niet te ontwarren zijn; algemeene maatschappelijke verhoudingen zien zij uiterst gebrekkig, eensdeels door het ontbreken van de grondbegrippen, anderdeels door hun onvermogen abstract te denken; de juiste beoordeeling van hun eigen plaats in het geheel, met de daarmede samengaande zelfcritiek en 
zelfbeoordeeling, ontbreekt in belangrijke mate; alsmede de beoordeeling van de positie van anderen (...). ${ }^{.628}$

Hierdoor zouden zwakzinnigen eerder in conflict kunnen komen met hun omgeving en daardoor liepen ze een grotere kans om crimineel te worden. Het belangrijkste middel om dat te voorkomen was volgens De Boer de combinatie van BLO en nazorg. Door onderwijs en daarop volgende maatschappelijke zorg zouden zwakzinnigen zich kunnen leren inpassen in de maatschappij, zonder crimineel gedrag te vertonen. ${ }^{629}$

De aanwezigheid van criminele zwakzinnigen in justitiële instellingen verklaarde hij vanuit het ontbreken van BLO en nazorg in de jeugd van die zwakzinnigen. Daardoor waren zij verwaarloosd en naar de criminaliteit afgegleden.

" Op grond van mijn ervaringen acht ik de stelling juist, dat:

Als er onder de gedetineerden een groot aantal zwakzinnigen voorkomt, dan zijn dit voor verreweg het meerendeel zwakzinnigen, die verwaarloosd zijn in hun jeugd, doordat zij een behoorlijke schoolsche opleiding hebben gemist (B.O.). Volgens de practijk der kinderwetten (...) is hier grove verwaarloozing der opvoeding, welke bestaat in verwaarloozing der geestelijke ontwikkeling." 630

Onder zijn eigen cliënten zag hij criminaliteit slechts sporadisch voorkomen.

"... ik had onder mijn oudleerlingen der B.O. school slechts één $1^{\mathrm{e}}$ klasse inbreker." ${ }^{631}$

De Boers stelling, dat zwakzinnigen door hun unieke persoonlijkheidsstructuur bij verwaarlozing het gevaar liepen naar de criminaliteit af te glijden was aan het einde van de jaren dertig algemeen geaccepteerd. Deze stelling kon heel wat negatiever worden uitgelegd dan De Boer dat deed. De Leidse katholieke hoogleraar in de psychiatrie E.A.D.E. Carp stelde, in de al eerder aangehaalde lezingencyclus voor het Leids Criminologisch Instituut, dat zwakzinnigen in principe allemaal, door de aard van hun afwijking, over een psychopathische persoonlijkheid beschikten en daardoor tot misdadig en ander afwijkend gedrag waren voorbestemd.

"Meer en meer dringt de opvatting door, dat zwakzinnigheid beschouwd dient te worden als een bijzonderen uitingsvorm van psychopathie en de zwakzinnige persoonlijkheid dus een gepsychopathiseerde persoonlijkheid is met alle gevolgen van dien. ${ }^{.632}$

Ook de psychiater D. Wiersma stelde in een artikel in het Tijdschrift voor Buitengewoon Onderwijs van april 1940 dat zwakzinnigheid en psychopathie nauw met elkaar samenhingen. Zwakzinnigen beschikten, door hun intelligentiedefect, over een ongunstig karakter en waren daardoor minder goed in staat om zich in de maatschappij te handhaven.

\footnotetext{
"Onderzoekingen, opzettelijk gericht op het opsporen van een samenhang tussen intelligentie en karakter zijn niet zoveel verricht, maar dat die samenhang bestaat en dat gunstige karakteruitingen meer bij intelligente, ongunstige eerder bij domme of zelfs zwakzinnige kunnen worden verwacht, is toch wel zeker. Wanneer dan ook de zwakzinnigen zich in de maatschappij minder goed kunnen handhaven, dan ligt dat niet alleen aan hun minderwaardige intelligentie, maar stellig eveneens - ofschoon niet noodzakelijk evenzeer - aan hun afwijkende temperaments- en karaktereigenschappen. ${ }^{.633}$
} 
Daarmee werden zwakzinnigheid en psychopathie weer nadrukkelijk met elkaar verbonden en was men vrijwel weer terug bij de stand van zaken zoals die aan het begin van de jaren tien van de twintigste eeuw bestond, toen zwakzinnigheid en psychopathie als synoniemen voor elkaar gebruikt werden.

\subsection{Ontwikkelingen in de nazorg}

\subsubsection{Groei van de nazorg}

In de jaren dertig bleef, ondanks de crisis, het aantal nazorginstellingen en werkinrichtingen voor oud-leerlingen van het BLO toenemen. Er was zelfs, in vergelijking met de jaren twintig, sprake van een bescheiden groeiversnelling. Toch bleef de groei van de nazorg ver achter bij die van het BLO. Tussen 1930 en 1939 werden er in Nederland 51 nieuwe scholen voor BLO gesticht, terwijl er in dezelfde periode 12 nazorginstellingen bijkwamen. ${ }^{634}$

In 1930 werd in Almelo de vereniging NABO (Nazorg Almelo Buitengewoon Onderwijs) opgericht, ${ }^{635}$ die in 1934 een werkinrichting opende. ${ }^{636}$ Gouda zag in hetzelfde jaar de oprichting van de vereniging Zorg voor Geestelik Misdeelden ${ }^{637}$ die in 1931 een werkinrichting opende. ${ }^{638}$ Het jaar daarna, in 1931, kreeg de Alkmaarse vereniging Zorg voor leerlingen en oud-leerlingen van de school voor $B L O$ van de gemeente een subsidie van fl. 1260,- $(€ 573,-)$ voor het oprichten van een werkinrichting. ${ }^{639}$ In Hengelo (O.) werd in 1932 de vereniging Zorg B.O. opgericht, nadat in 1931 het BLO in deze gemeente van start was gegaan. ${ }^{640}$ In 1934 opende deze vereniging een werkinrichting. ${ }^{641}$ In Apeldoorn werd eveneens in 1932 een werkinrichting geopend door de Wilhelmina-stichting, ooit begonnen als een afdeling van de Vereeniging Maatschappelijk Werk bij Zenuwlijden en Krankzinnigheid. ${ }^{642}$ In Maastricht werd in 1933 de R.K. Stichting Zwakzinnigenzorg opgericht, die twee jaar later een maatschappelijk werkster als inspectrice voor de nazorg aanstelde. ${ }^{643}$ In Zwolle werd in 1935 de vereniging NABO (Nazorg Buitengewoon Onderwijs) opgericht, die in 1939 haar werkinrichting begon. ${ }^{644}$ In Enschede werd in 1936 de vereniging ZENBO (Zorg en Nazorg B.O.) opgericht, ${ }^{645}$ in januari 1940 opende deze vereniging een werkinrichting. ${ }^{646}$ Ook in IJmuiden/Velsen en Hilversum ontstonden in deze periode werkinrichtingen. ${ }^{647}$

In Rotterdam werd, zoals ik al in paragraaf 5.4.1 heb behandeld, op grond van een rapport uit 1927 in $1930 \mathrm{~L}$. Bodaan aangesteld als nazorgambtenaar. Tegen het advies van Bodaan in, besloot het Rotterdamse gemeentebestuur om geen gemeentelijke werkinrichting te starten. ${ }^{648}$ Dat werd overgelaten aan het particulier initiatief. Het leidde tot het ontstaan van twee werkinrichtingen, één voor het christelijk en één voor het openbaar BLO. In 1933 opende de vereniging Zorg en $\mathrm{Na}$ zorg voor Zwakzinnigen in Rotterdam-Zuid, verbonden aan de christelijke BLOschool, een werkplaats voor jongens onder leiding van de onderwijzer G.J. Van der Ploeg. ${ }^{649}$ In 1934 was het de beurt aan de vereniging Zorg voor ' $t$ Achterlijke Kind, die zich op de openbare scholen voor BLO richtte en eveneens een jongenswerkplaats oprichtte, onder leiding van de onderwijzer Willeboer. In 1938 opende deze werkinrichting een afzonderlijke afdeling voor meisjes. ${ }^{650}$ De christelijke werkinrichting volgde dit voorbeeld in $1939 .{ }^{651}$

Ook in Den Haag was eind jaren twintig door het gemeentebestuur opdracht gegeven om een rapport te schrijven over de vraag, in hoeverre er behoefte 
bestond aan nazorg voor oud-leerlingen van het BLO. Het deel van het rapport dat over criminaliteit ging heb ik al in paragraaf 6.2 .4 behandeld. Het rapport bevatte meer onderzoeken die dieper gingen dan eerdere nazorgrapporten, onder andere naar het milieu van de leerlingen en de achtergrond van hun ouders. De conclusie hierover luidde, dat

\section{"...kan worden vastgesteld, dat de gezinnen waaruit de kinderen afkomstig zijn, veelal behooren tot een maatschappelijke groep wier welvaart niet boven die van goede arbeidersgezinnen uitkomt, en zelfs voor een zeer belangrijk aantal daar beneden ligt."}

Verder werd onderzocht hoe de oud-leerlingen functioneerden in de maatschappij. Dat leverde een beeld op dat niet bijzonder afweek van de eerdere onderzoeken in Amsterdam (1917), Haarlem (1924) en Rotterdam (1927). ${ }^{653}$ Het rapport stelde voor om een ambtenaar voor de nazorg te benoemen ${ }^{654}$ en om de opening van een werkinrichting door de plaatselijke afdeling van de AVO mogelijk te maken. ${ }^{65}$ Verder zou er avondverzorging moeten komen. ${ }^{656}$ Maar de slechte financiële omstandigheden van de gemeente leidden ertoe, dat alleen de benoeming van de ambtenaar tot stand kwam. Dat gebeurde pas in 1939, toen de BLO-onderwijzer G.H. van Dijk met zijn werkzaamheden begon. Oud-leerlingen van het BLO die voor hun daginvulling op een werkinrichting waren aangewezen, konden terecht op de werkplaatsen van de vereniging Schroeder van der Kolk, een voormalige afdeling van de Vereeniging Maatschappelijk Werk bij Zenuwlijden en Krankzinnigheid.

In de loop van de jaren dertig nam niet alleen het aantal gemeentelijke nazorginstellingen toe, ook werd de aanzet gegeven voor nazorg op provinciaal niveau, ten behoeve van gemeenten die niet over een nazorginstelling beschikten. Hierbij speelden de kruisverenigingen een belangrijke rol. Het eerste initiatief hiertoe werd genomen in Zuid-Holland, waar in september 1933 de gepensioneerde Vlaardingse BLO-onderwijzer C. Leeflang door de vereniging Het Groene Kruis werd aangesteld als sociaal-paedagoog. In deze functie adviseerde hij de Commissie voor het Misdeelde Kind,

"... die haar taak meent te vinden in de behartiging der belangen van allerlei minderwaardigen, zo kinderen als volwassenen.'

Hij stelde zich tot taak om de oprichting van scholen voor BLO en nazorginstellingen te bevorderen en in gemeenten zonder nazorginstellingen zijtakken op te richten. ${ }^{658}$ In de praktijk hield het werk van deze provinciale sociaalpedagoog vooral het testen van kinderen in, om te bepalen of ze in aanmerking kwamen voor plaatsing op het BLO. Ook het onderhandelen met gemeenten en schoolbesturen over het toelaten van kinderen uit andere plaatsen op hun BLO-scholen en de financiële afhandeling hiervan behoorden tot de veel voorkomende werkzaamheden van de sociaalpedagogen. ${ }^{659} \mathrm{Op}$ het eigenlijke nazorggebied waren de activiteiten van Leeflang praktisch nihil. Hij bracht wel eens een bezoek aan een werkinrichting en in 1935 deed hij een vruchteloze poging in Leiden een vereniging voor zwakzinnigenzorg op te richten. ${ }^{660}$

In Noord-Brabant probeerde men de provinciale zwakzinnigenzorg, zoals al in paragraaf 4.3.1 bij het ontstaan van de Bredase nazorg is aangegeven, te kop- 
pelen aan de ambulante geestelijke gezondheidszorg. De buitendienst van Huize Voorburg, die in de gehele provincie consultatiebureaus had, werd in 1936 overgenomen door de Provinciale Commissie voor Geestelijke Gezondheidszorg van het Witgele Kruis. ${ }^{661}$ Aan deze consultatiebureaus werd Th. J. Potters, de leider van de Bredase nazorg, als sociaalpedagoog verbonden. ${ }^{662} \mathrm{Hij}$ kreeg vergelijkbare taken als Leeflang in Zuid-Holland. Ook voor hem was het onderzoeken van kinderen of zij voor toelating op het BLO in aanmerking kwamen de belangrijkste werkzaamheid. $^{663}$

In 1938 stelde het Groene Kruis in Gelderland twee sociaalpedagogen aan, de BLO-onderwijzers Van Toledo en Grootjans, beiden betrokken bij de Apeldoornse werkinrichting. Ook zij hielden zich vooral bezig met toelatingskwesties tot het BLO. ${ }^{664}$

In Overijssel was in 1939 als sociaalpedagoog L.C. Carstens actief, hoofd van de Zwolse school voor BLO en leidinggevende van de werkinrichting aldaar. Als sociaalpedagoog wist hij er drie personen tewerk te stellen. ${ }^{665}$

In de jaren dertig nam ook het aantal cliënten waarvoor nazorginstellingen verantwoordelijk waren toe. Ondanks het feit, dat vanaf het begin van de jaren dertig de cijfers van de nazorg in de verslagen van het Centraal Bureau voor de Statistiek over het BLO waren opgenomen, zijn er slechts twee jaren waarin het totale aantal nazorgpupillen met een redelijke waarschijnlijkheid vast te stellen is. Dat waren 1936 en 1937. In 1936 waren er in totaal 4593 personen bij de nazorg ingeschreven, waarvan 3448 afkomstig van het BLO. Een jaar later was dat aantal gestegen tot 4876 , waarvan er 3704 afkomstig waren van het BLO. ${ }^{666}$ Het is, deze cijfers naar twee kanten extrapolerend, redelijk te veronderstellen dat in de jaren dertig het aantal nazorgpupillen steeg van rond de 4000 in 1930 tot iets meer dan 5000 rond 1940. Overigens wordt uit de verslagen van het CBS niet duidelijk, hoe de verschillende nazorginstellingen hun pupillen telden. Sommige nazorgwerkers telden alleen de pupillen mee die dat jaar van school kwamen, anderen telden alle personen mee die ooit een beroep op de nazorg hadden gedaan. Daardoor zijn deze cijfers niet betrouwbaar.

Cijfers over de groei van het aantal pupillen bij de verschillende individuele nazorginstellingen zijn sporadisch voorhanden. $\mathrm{Zij}$ geven een indicatie van de groei, die andere nazorginstellingen ongetwijfeld ook hebben doorgemaakt. In Amsterdam had Pier de Boer over het jaar 1926 de verantwoordelijkheid voor 422 oud-leerlingen van het BLO. In 1934 was hun aantal gestegen tot 1393, in 1938 tot 1779 oud-leerlingen. Daarnaast voerde de nazorg de maatschappelijke hulp aan andere geestelijk onvolwaardigen uit. Hun aantal groeide van 39 in 1926 tot 513 in 1934 en 607 in $1938 .{ }^{667} \mathrm{Bij}$ deze grote aantallen pupillen, van 461 in 1926 tot 2386 in 1938, moet bedacht worden dat deze getallen cumulatief zijn: alle personen die ooit in contact waren geweest met de nazorg, werden blijvend als cliënt beschouwd. Hun gegevens bleven in De Boers kaartsysteem bewaard. Intensieve hulp werd aan een aanzienlijk kleinere groep personen verleend, diegenen die pas sinds betrekkelijk korte tijd een beroep op de nazorg deden. De nazorg had in 1935 met 213 oud-leerlingen van het BLO minstens éénmaal per week contact, met 460 van hen éénmaal per veertien dagen. Met de overigen was het contact sporadisch. 
In Maastricht begon H.J.M. Majoie in 1935 haar nazorgwerk met 167 pupillen, ${ }^{668}$ een aantal dat uitgroeide tot 304 in 1939. Bij haar ging het allemaal om oud-leerlingen van de scholen voor BLO. ${ }^{669}$

De cijfers van de oud-leerlingen van het BLO die op de werkinrichtingen tewerkgesteld waren werden beter en eenduidiger bijgehouden. Landelijk was hun aantal in $192795,{ }^{670}$ in 1937 was dat gestegen tot $444,{ }^{671}$ Het aantal werkinrichtingen voor lichtzwakzinnigen steeg van 6 in $1929^{672}$ tot 25 in $19388^{673}$ Het is duidelijk, dat het aantal pupillen op de werkinrichtingen maar een fractie uitmaakte van het totale aantal nazorgpupillen. Toch werd aan deze groep veel energie besteed. Het draaiende houden van een werkinrichting kostte veel tijd en inspanning, zeker met alle moeilijkheden die zich in de jaren dertig voordeden.

\title{
6.3.2 Financiering van de nazorg
}

Dat de nazorg in de jaren dertig kon doorgroeien mag een wonder heten. In deze periode trok de overheid zich steeds verder terug uit het maatschappelijke leven vanwege de grote financiële problemen. Belangrijk argument voor gemeenten om toch in nazorg te investeren bleef, net als in de jaren twintig, de bezuiniging die ermee bereikt zou kunnen worden op de gestichtsverpleging voor armlastige zwakzinnigen. Binnen de nazorg werd echter aan het begin van de jaren dertig nadrukkelijk aan de geldigheid van dit argument getwijfeld, vooral door De Boer en Schuyt

\begin{abstract}
"De hr. Schuyt heeft de overtuiging, dat als Haarlem morgen de werkinrichting sluit, dit de gemeente beslist financiële voordeelen zou bezorgen eenvoudig omdat de ouders van den kinderen geen afstand willen doen en de aanvragen om plaatsing in een inrichting zeer gering zullen zijn. (...)

We moeten in geen geval trachten aan te toonen dat een verpleging in een werkinrichting slechts 2 à fl. $300,-(€ 91,-$ tot $€ 150,-, L B)$ per jaar kost. Dit is in werkelijkheid veel en veel meer. ${ }^{\circ 74}$
\end{abstract}

Zij vonden dat gemeenten vooral op inhoudelijke gronden voor nazorg zouden moeten kiezen boven gestichtsverzorging. Ze waren van mening, dat het recht van zwakzinnigen op een eigen plaats in de samenleving zwaarder moest wegen dan het financiële argument.

\section{"We moeten deze zaak niet als een financiële zien, doch wijzen op de sociale en moreele gevolgen ${ }^{2675}$}

Deze principiële stelling bleek in loop van de jaren dertig niet houdbaar. Door de voortdurende economische crisis bleken lokale overheden alleen nog maar gevoelig voor financiële argumenten. Die werden daarom veelvuldig gehanteerd. Zo stelde Van Voorthuijsen in 1935, dat maar liefst éénderde deel van de tewerkgestelden op de werkinrichtingen bij opheffing daarvan direct naar een gesticht zou moeten worden overgebracht. ${ }^{676}$ In het vorige hoofdstuk, in paragraaf 5.4.2 heb ik al aangehaald, dat er aanwijzingen zijn dat deze stelling niet geheel opging. In de jaren dertig kwamen er extra gegevens beschikbaar, die erop wijzen dat de nazorg veel minder diende om gestichtsplaatsingen te voorkomen dan de sector zelf aan de subsidiegevers wilde doen voorkomen. Uit de gegevens van het CBS over het 
BLO, die vanaf 1929 aanvankelijk jaarlijks en later om de drie jaar gepubliceerd werden, blijkt dat het grootste deel van de BLO-leerlingen dat voor gestichtsplaatsing in aanmerking kwam, al tijdens de schooltijd in residentiële instellingen werd geplaatst. Tabel 11 laat dat duidelijk zien.

\section{Tabel 11}

\begin{tabular}{|c|c|c|c|c|c|}
\hline Jaar & 1930 & 1932 & 1934 & 1936 & 1938 \\
\hline $\begin{array}{l}\text { School verlaten vóór } \\
\text { het einde van de leertijd }\end{array}$ & 859 & 1120 & 1304 & 886 & 1620 \\
\hline $\begin{array}{l}\text { vanwege plaatsing in } \\
\text { gesticht }\end{array}$ & 95 & 113 & 118 & 110 & 168 \\
\hline $\begin{array}{l}\text { School verlaten bij het } \\
\text { einde van de leertijd }\end{array}$ & 730 & 1146 & 1439 & 1859 & 2118 \\
\hline $\begin{array}{l}\text { daarna naar een gesticht } \\
\text { overgebracht }\end{array}$ & 6 & 10 & 36 & - & - \\
\hline
\end{tabular}

Het geheel wegvallen van de gestichtsplaatsingen van leerlingen die het BLO helemaal hadden doorlopen aan het einde van de jaren dertig zou op het conto van de nazorg kunnen worden geschreven. Hierbij kunnen echter tal van andere factoren een rol hebben gespeeld, eenduidige gegevens hierover ontbreken.

Zelfs met het bezuinigingsargument in de hand bleek het in de jaren dertig moeilijk om een nieuwe nazorginstelling te stichten. Ter illustratie hiervan behandel ik de ontstaansgeschiedenis van twee nazorginstellingen in de jaren dertig, die van Maastricht en van Zwolle.

$\mathrm{Al}$ sinds 1918 bestond in Maastricht een vorm van nazorg, die door een vrijwilliger van de armenraad werd uitgevoerd.

\footnotetext{
"Met alle waardering voor diens werk, moeten wij echter verklaren, dat dit toezicht onvoldoende is. Wij hebben de overtuiging, dat èn de ouders èn de patroons van de oud-leerlingen minstens elke 3 maanden moeten bezocht worden. Voeg daarbij het steeds stijgend aantal oud-leerlingen, dan zal het voor iedereen duidelijk zijn, dat voor een dergelijk toezicht enkele vrije uren beslist onvoldoende zijn." 678
}

In 1928 opende in Maastricht de plaatselijke afdeling van de AVO een werkplaats voor onvolwaardige arbeidskrachten. Hier werd plaats ingeruimd voor drie oudleerlingen van het BLO, later kwam er voor deze groep een aparte afdeling. ${ }^{679}$ Deze AVO-afdeling vroeg in 1931 bij de gemeente Maastricht een subsidie aan om een nazorgambtenaar te kunnen aanstellen. Dat verzoek werd begin 1933 afgewezen. ${ }^{680}$ De AVO besloot daarop, het initiatief om tot nazorg te komen over te laten aan de scholen voor BLO. Broeder Jan Baptist, schoolhoofd van de R.K. jongensschool voor BLO, benaderde daarop enkele notabelen en in de zomer van 1933 werd de R.K. Stichting Zwakzinnigenzorg opgericht. De stichting stelde een inspectrice voor de nazorg aan, die dit werk voorlopig op vrijwillige basis verrichtte. Aan de ge- 
meenteraad werd een subsidie van fl. 2700,- $(€ 1227,-)$ per jaar gevraagd. Het belangrijkste argument dat daarbij werd gegeven, was dat door de nazorg op gestichtsplaatsingen zou kunnen worden bezuinigd. ${ }^{681}$ Ter ondersteuning van dit betoog werd een jaarverslag aangehaald van de Inrichting voor Zwakzinnigen te Ermelo uit het begin van de jaren dertig:

"Het meest opmerkelijk is het feit, dat de toevloed van verpleegden lang zoo groot niet meer is als eenige jaren geleden.

Een der oorzaken van de vermindering der aanvragen zoeken wij in de oprichting der Werkinrichtingen voor zwakzinnigen in de groote steden. Door het bestaan van deze instellingen worden meerdere kinderen geholpen, die vroeger noodwendig naar een gesticht moesten gezonden worden, omdat zij de Buitengewone School niet meer konden bezoeken en voor den gewonen arbeid weinig of niet geschikt waren. ${ }^{.662}$

De gemeente bleek voorlopig niet bereid om geld aan de nazorg uit te geven. In maart 1934 werd besloten de subsidie niet toe te kennen vanwege de slechte financiële toestand. ${ }^{683}$ Een maand later, in april 1934, sprak broeder Jan Baptist hierover met de wethouder van Onderwijs. ${ }^{684}$ Die verklaarde zich bereid het subsidieverzoek opnieuw in de raad te brengen, als deze zou worden verlaagd tot fl. 2300,- ( $€$ $1045,-)$ per jaar. ${ }^{685}$ De gemeenteraad ging akkoord en op 20 december 1934 werd aan de stichting een jaarlijkse subsidie van fl. $2000,-(€ 909,-)$ toegekend. ${ }^{686}$ Op 1 september 1935 kon de inspectrice voor de nazorg, H.J.M. Majoie, in loondienst worden aangesteld, ${ }^{687}$ vier jaar nadat een eerste subsidieaanvraag bij de gemeente was gedaan.

In Zwolle organiseerde in maart 1934 de Vereeniging ter behartiging van de belangen van leerlingen en oud-leerlingen der school voor buitengewoon lager onderwijs te Zwolle een bijeenkomst om de belangstelling voor haar activiteiten op te wekken. De burgemeester fungeerde als erevoorzitter en Van Voorthuijsen hield er een inleiding. ${ }^{688}$ Veel indruk moet deze bijeenkomst in eerste instantie niet hebben gemaakt, want pas een jaar later, in april 1935, werd de vereniging omgezet in rechtspersoon onder de naam Nazorg Buitengewoon Onderwijs (NABO). Deze vereniging besloot zich in eerste instantie bezig te houden met de oprichting van een werkinrichting. Men ging hiervoor fondsen werven, onder andere bij de gemeente. ${ }^{699}$ Ook in Zwolle gebruikte men de mogelijke bezuiniging op gestichtsplaatsingen als argument.

"Indien hier geen werkinrichting tot stand komt, zullen meerdere kinderen naar een inrichting moeten wat voor de gemeenschap veel duurder is. Totstandkoming van een werkplaats zal dus zijn zowel in 't belang der gemeente als in 't belang van de tewerkgestelde. ${ }^{690}$

Subsidie werd er, vanwege de moeilijke financiële omstandigheden van de gemeente, voorlopig niet toegekend. ${ }^{691}$ Uiteindelijk lukte het pas in 1939, vijf jaar na de eerste bijeenkomst, een werkinrichting te openen, toen de gemeente een bijdrage van fl. 200,- ( $€ 91,-)$ per pupil per jaar toezegde. ${ }^{692}$

Niet alleen het opstarten van een nazorginstelling was moeilijk in de jaren dertig, ook het instandhouden van alle onderdelen ervan was niet altijd even gemakkelijk. 
Er werden in verschillende gemeenten pogingen ondernomen om op de nazorg te bezuinigen. Zo wilde de gemeente Haarlem in 1933 de subsidie van de werkinrichting met fl. 2000,- ( $€ 909,-)$ per jaar verlagen en de avondverzorging afschaffen. $\mathrm{Na}$ protest van Schuyt bleef de avondverzorging gehandhaafd. ${ }^{693}$ Ook Pier de Boer kreeg met gemeentelijke bezuinigingen te maken, toen in 1934 zijn jaarsalaris van fl. $4200,-(€ 1909,-)$ naar fl. $3480,-(€ 1582,-)$ verlaagd dreigde te worden. Hij maakte hiertegen met succes bezwaar. ${ }^{694}$

Het lukte lang niet overal om voorgenomen bezuinigingen terug te draaien. Vooral de avondverzorging werd op verschillende plaatsen aangepakt. In Zaandam werd al in 1930 het avondonderwijs, ondanks protesten van O\&A, opgeheven. ${ }^{695}$ In Rotterdam en Vlaardingen werd in 1934 de subsidiëring van de avondverzorging eveneens stopgezet. ${ }^{696}$ In Alkmaar deed het college van B\&W eind 1936 een voorstel aan de gemeenteraad om de subsidie aan de nazorg belangrijk te verminderen. De raad liet de werkinrichting ongemoeid, ${ }^{697}$ maar ook hier sneuvelde het avondonderwijs. ${ }^{698}$

\section{Tabel 12}

Subsidiëring van werkinrichtingen voor zwakzinnigen door gemeenten over het jaar $1937^{699}$ (het getal tussen haakjes is het bedrag in euro's).

\begin{tabular}{|c|c|c|c|c|c|c|c|}
\hline Gemeente & $\begin{array}{l}\text { Kosten } \\
\text { bouw }\end{array}$ & ge- & $\begin{array}{l}\text { Toegeke } \\
\text { Subsidi }\end{array}$ & nde & $\begin{array}{l}\text { Aantal } \\
\text { pupil- }\end{array}$ & $\begin{array}{l}\text { Subsidi } \\
\text { pupil pe }\end{array}$ & $\begin{array}{l}\text { ie per } \\
\text { er jaar }\end{array}$ \\
\hline Vlaardingen & Gratis & & 3600 ,- & (1636) & 18 & 327,30 & $(148,77)$ \\
\hline Amsterdam & Gratis & & 49.140,- & (22336) & $182^{*}$ & 270 & $(67,62)$ \\
\hline Delft & Gratis & & 8000 ,- & (3636) & 40 & 200 & $(90,91)$ \\
\hline Zaandam & Gratis & & 2200 ,- & (1000) & 11 & 200 & $(90,91)$ \\
\hline Arnhem & 540 ,- & (245) & 13.000,- & (5909) & 65 & 191,70 & $(87,14)$ \\
\hline Velsen & Gratis & & 1880 ,- & (855) & 10 & 188 & $(85,45)$ \\
\hline Hilversum & Gratis & & 2000 ,- & (909) & 14 & 142,85 & $(64,93)$ \\
\hline Utrecht & Gratis & & 4500 ,- & (2045) & 33 & 136,40 & (62) \\
\hline Haarlem & Gratis & & 5535 ,- & (2516) & 41 & 135 & $(61,36)$ \\
\hline Schiedam & 500 ,- & (227) & 2250 ,- & (1023) & 13 & 134,40 & $(61,09)$ \\
\hline Rotterdam-Z & 1200 ,- & (545) & 2880 ,- & (1309) & 14 & 120 & $(54,55)$ \\
\hline Rotterdam-C & 1200,- & (545) & 2880 ,- & (1309) & 14 & 120 & $(54,55)$ \\
\hline Alkmaar & Gratis & & 1000 ,- & (455) & 9 & 111,10 & $(50,50)$ \\
\hline Dordrecht & 1300,- & (591) & 5000 ,- & (2273) & 36 & 102,80 & $(46,73)$ \\
\hline Breda & Gratis & & 1000 ,- & (456) & 11 & $\begin{array}{l}91 \\
(41,36)\end{array}$ & \\
\hline Groningen & 400 -- & (182) & 3000 ,- & (1364) & 30 & 86,70 & $(39,41)$ \\
\hline
\end{tabular}

* Op basis van de gegevens over 1936

Ondanks deze bezuinigingen gaven de meeste gemeenten waar een nazorginstelling bestond aan het einde van de jaren dertig meer aan de nazorg uit dan aan het begin van het decennium. Wel waren er grote onderlinge verschillen tussen de subsidiebedragen die per gemeente aan nazorg werden besteed. Dat wordt duidelijk als de jaarlijkse subsidiebedragen worden gedeeld door het aantal tewerkgestelden, zoals te zien in tabel 12.

Tussen de hoogste subsidie per pupil per jaar in Vlaardingen en de laagste, in Breda, ligt een verschil van fl. 236,30. ( $€ 107,41)$ Wat verder opvalt aan deze cijfers is dat de oudere instellingen, die in de loop van de jaren twintig waren opge- 
richt, de meeste subsidie per tewerkgestelde per jaar ontvingen. Uitzondering hierop vormde Dordrecht, maar dat is te verklaren door een forse toename van het aantal tewerkgestelden in de jaren dertig, die niet werd gecompenseerd door een evenredige toename van de subsidie.

\subsubsection{Ontwikkeling van de praktijk}

Het model voor de nazorg dat Pier de Boer in 1924 in het Haarlemse Nazorgrapport had ontwikkeld, bleef gedurende de jaren dertig actueel. Het was ook in deze periode de belangrijkste leidraad voor de organisatie en invulling van de zorg voor oud-leerlingen van het BLO. Belangrijkste kenmerk van de inhoudelijke ontwikkeling van de nazorg in de jaren dertig was, dat deze zich amper inhoudelijk ontwikkelde. Van vernieuwing was nauwelijks sprake. Aanvullingen op het nazorginstrumentarium deden zich voor, maar zijn vooral te beschouwen als een pragmatische reactie op ontwikkelingen in de praktijk. Ze kwamen niet voort uit een veranderende visie op het nazorgwerk.

Als reactie op het ouder worden van de populatie nazorgpupillen kwam het in de loop van de jaren dertig in Amsterdam tot vormen van gezinsverpleging. Steeds meer oud-leerlingen van het BLO konden niet langer bij hun ouders wonen, omdat die de zorg niet meer aankonden of overleden. Om te voorkomen dat deze pupillen door deze omstandigheden alsnog in een inrichting opgenomen moesten worden, plaatste De Boer hen zoveel mogelijk in pleeggezinnen binnen Amsterdam. In 1935 ging het daarbij om 50 nazorgpupillen. ${ }^{700}$

Toen bleek dat een deel van de zelfstandig wonende Amsterdamse nazorgpupillen niet in staat was om het eigen geld verantwoord te beheren, organiseerde De Boer een speciale vorm van financiële hulpverlening. Er kwam een aparte afdeling van het Gemeentelijk Bureau voor Maatschappelijke Steun (een voorloper van de Sociale Dienst) die voor deze groep nazorgpupillen het financiële beheer voerde. De Boer werd de leider van deze afdeling, die daardoor in de praktijk integraal onderdeel van de nazorg uitmaakte.

"Voor het merendeel der pupillen wordt kamerhuur betaald, ook het middageten, terwijl het resterende bedrag aan hen zelf wordt verstrekt voor de verzorging van brood en andere onkosten. ${ }^{701}$

Eind 1934 waren hier 22 oud-leerlingen ingeschreven, een jaar later waren dat er $37 .^{702}$

Het vrijwel ontbreken van inhoudelijke vernieuwingen bij de nazorg in de jaren dertig had vooral te maken met de moeilijke omstandigheden die het gevolg waren van de economische crisis. Nazorginstellingen moesten daardoor veel meer tijd en energie besteden aan het bestrijden van de crisisverschijnselen. Ze moesten zich nadrukkelijker verantwoorden aan de subsidiegevers, vooral de gemeenten, die zo zuinig mogelijk met hun budget omsprongen. Het werd door de crisis ook moeilijker om nazorgpupillen in werk te plaatsen. Werkgevers die personeel zochten, hadden het voor het uitzoeken en kozen eerder voor een volwaardige dan een onvolwaardige arbeidskracht. Het enige voordeel dat nazorgpupillen hadden was dat aan hen, vanwege hun verminderde arbeidsproductiviteit, minder loon betaald hoefde te worden. Ook de bedrijfsvoering van de werkinrichtingen werd er door de 
crisis niet makkelijker op. De afzet van de producten verliep door de algemene daling van de koopkracht moeilijker en de grondstoffenvoorziening liep zo nu en dan gevaar.

Wat hierbij een rol speelde was, dat in de jaren dertig de experimentele fase van de nazorg voorbij was. In de jaren twintig was de nazorg ontstaan en de methodiek ontwikkeld. De jaren dertig waren veel meer het decennium van de consolidatie en langzame uitbouw van de nazorg, gebruik makend van de ervaringen die in de jaren twintig waren opgedaan.

\subsection{Samenwerking binnen de nazorg}

"14 maart 1931 te 2 u n.m. had op voorstel van den heer P. De Boer, ambtenaar voor de Nazorg BO. te Amsterdam, een samenkomst plaats op zijn bureau, N. Achtergracht 100, met de leiders van de Nazorg uit verschillende plaatsen van ons land. ${ }^{703}$

Met deze woorden opende E.P. Schuyt, de Haarlemse nazorgwerker, het eerste notulenschrift van de nazorggroep. Deze groep bestond uit Pier de Boer uit Amsterdam, A.H.D. Wepster uit Dordrecht, E.P. Schuyt uit Haarlem, H. Werkhoven uit Arnhem en H. Frantsen uit Vlaardingen. Ze hadden besloten dat de tijd was gekomen om een eigen landelijke organisatie op te richten, waarin alleen zaken die met de nazorg te maken hadden aan de orde zouden komen zonder dat daarbij vertegenwoordigers van andere werkvelden betrokken waren. Het doel was, zoals Pier de Boer het uitdrukte, gezamenlijk de nazorg verder vorm te geven,

"... doordat we beter op de hoogte kwamen van elkaars werk, zoodat er meer lijn kwam in ons werk." 704

Voorlopig werd De Boer voorzitter, Schuyt secretaris en Wepster penningmeester. ${ }^{705} \mathrm{Bij}$ de tweede vergadering, op 19 september 1931, was ook J.J.C. van der Wouden, de Delftse nazorgwerker, aanwezig. ${ }^{706}$ Tijdens deze eerste vergaderingen werd gesproken over een uniforme registratie van de gegevens van oud-leerlingen en hun classificatie aan de hand van de mate waarin zij voor arbeid geschikt waren. ${ }^{707}$ Men besloot ook om alle bestaande nazorginstellingen en werkinrichtingen aan te schrijven voor een vergadering die op 12 maart 1932 werd gehouden. Hier kwamen vertegenwoordigers van 10 van de in totaal 14 bekende nazorginstellingen. Naast de initiatiefnemers kwamen er vertegenwoordigers uit Utrecht, Apeldoorn, Schiedam, Hilversum en Breda. Zij besloten de nazorggroep om te zetten in de Nederlandsche Vereeniging Nazorg Buitengewoon Onderwijs (NVNBO). De bestuurlijke samenstelling bleef gelijk. ${ }^{708}$ Doel van deze vereniging werd,

... dat deze Nazorg in handen zal blijven van onderwijzers, die deze kinderen kennen en dat door combinatie van verschillende groepen van maatschappelijk mindergeschikten onze groep niet in de verdrukking komt. ${ }^{709}$

Opvallend is het ontbreken van de Rotterdamse nazorgambtenaar, L.J. Bodaan, die in 1931 was aangesteld. Hij werd niet genoemd in de overzichten die de jonge NVNBO maakte van bestaande nazorginstellingen en werkinrichtingen en werd ook niet uitgenodigd voor vergaderingen van de vereniging, terwijl vertegenwoordigers van de twee Rotterdamse werkinrichtingen voor oud-leerlingen van het BLO 
wel actief lid werden. Een mogelijke verklaring hiervoor was het hybride karakter van de taken van Bodaan. Hij was nazorgambtenaar in deeltijd naast zijn functie als Ambtenaar voor Advies inzake de Opvoeding van de Rijperen Jeugd ${ }^{10}$ en vormde daarmee een buitenbeentje onder de nazorgambtenaren. Hij was niet uit het BLO afkomstig, daardoor niet specifiek deskundig op het gebied van zwakzinnigenzorg en hij combineerde zijn taak met de zorg voor de normale jeugd.

De NVNBO organiseerde op 23 april 1932 een tweede belangrijke bijeenkomst, die bedoeld was om de nazorg voor oud-leerlingen van het BLO in brede kring te propageren. Uitgenodigd waren alle gemeente- en schoolbesturen die met het $\mathrm{BLO}$ te maken hadden. Op de bijeenkomst waren bijna vijftig personen aanwezig. Onder hen bevonden zich A. van Voorthuijsen, de inspecteur van het BLO, de Arnhemse wethouder voor onderwijs en een vertegenwoordiger van het Centraal Bureau voor Statistiek. Verder waren er de zes nazorgambtenaren, dertig vertegenwoordigers van het openbare $\mathrm{BLO}$, vijftien vertegenwoordigers van het bijzonder $\mathrm{BLO}$ en vertegenwoordigers van de drie organisaties van $\mathrm{BLO}$-onderwijzers (algemeen, christelijk en katholiek). In zijn inleiding op deze vergadering, wees Van Voorthuijsen op het belang van de nazorg voor oud-leerlingen van het BLO. Hij stelde,

"... dat het geven van onderwijs aan zwakzinnige leerlingen van 6-14 jaar niet voldoende is. Zij die zich aan deze taak van onderwijs wijden, moeten meer dan leerkrachten, zij moeten maatschappelike werkers zijn." 711

Een tweede doel van de vergadering was, de schoolbesturen te wijzen op het belang van de registratie van gegevens van leerlingen en oud-leerlingen van het BLO. Ook al kon nog niet direct met het nazorgwerk begonnen worden in een plaats, vond men het toch belangrijk dat men alvast een registratiesysteem opzette, zodat als men later met nazorg zou beginnen, de gegevens alvast aanwezig waren.

De vergadering mistte zijn uitwerking niet. In enkele gemeenten, waaronder Maastricht, werden daadwerkelijke stappen gezet om tot nazorg te komen. Ook bevorderde de bijeenkomst de naamsbekendheid van de NVNBO: Van Voorthuijsen deed er uitgebreid verslag van in de BLO-bladen. Het was een eerste stap in de erkenning van de NVNBO als dé landelijke organisatie voor de nazorg. De vereniging groeide uit tot een interconfessioneel overleg- en belangenbehartigingsorgaan waaraan vrijwel alle nazorgwerkers zouden deelnemen. Uiteindelijk telde de vereniging in 1939 zo'n twintig deelnemende organisaties. Daarbij valt op dat, naast de Rotterdamse nazorgambtenaar, ook de Groninger werkinrichting nooit aan enige bijeenkomst van de NVNBO heeft deelgenomen.

De hoofddoelstelling van de vereniging werd door Pier de Boer in 1935 als volgt omschreven:

"... het gunstig beïnvloeden van een doelmatige ontwikkeling van de nazorg voor buitengewoon onderwijs in Nederland. ${ }^{712}$

De vereniging kreeg het karakter van een discussieforum, waarop een langzaam groeiende groep betrokkenen op regelmatige basis, dat wil zeggen twee maal per jaar, met elkaar de lopende zaken besprak. Er kwamen vooral praktische zaken aan de orde, waarbij de problemen met de grondstoffenvoorziening van de werkinrichtingen de boventoon voerden, maar er werden ook inhoudelijke discussies gevoerd 
over de plaats en de ontwikkeling van de nazorg.

In tijden van plotseling opdoemend gevaar werden er extra vergaderingen gehouden. Ook zaten bestuursleden, als vertegenwoordigers van de vereniging, in besturen en commissies van andere verenigingen, o.a. van O\&A, AVO en de Centrale Vereeniging ter Behartiging van de Belangen van Zenuw- en Zielszieken. De organisatie bleef klein en de leiding bleef de gehele jaren dertig in handen van het driemanschap De Boer, Wepster en Schuyt.

Ondanks het interconfessionele karakter van de NVNBO ging de verzuiling niet aan de nazorg voorbij. Tot aan het einde van de jaren twintig waren instellingen die zich met de nazorg voor oud-leerlingen van het BLO bezighielden neutraal of interconfessioneel geweest. Ze bedienden kinderen van alle gezindten voor BLO in de gemeente waarin ze actief waren. Alleen onderdelen van de nazorg die een levensbeschouwelijk karakter droegen, zoals de avondverzorging, werden aan de verschillende denominaties overgelaten. Vanaf 1929, met het ontstaan van de katholieke Bredase nazorg, ontstonden er meer organisaties die zich op slechts één levensbeschouwing richtten. Dordrecht had in 1934 de primeur van twee nazorginstellingen binnen de gemeente, toen de vereniging Chrizona werd opgericht, die zich richtte op de oud-leerlingen van de Dordtse christelijke school voor $\mathrm{BLO}^{713}$ en dus naast de nazorg van Wepster op zijn openbare school kwam te staan. Chrizona opende in 1936 een eigen werkinrichting. ${ }^{7 / 4}$ Ook in Rotterdam waren er twee werkinrichtingen, een algemene ${ }^{715}$ en een protestants-christelijke. ${ }^{716}$ Toch waren dergelijke constructies een uitzondering: in veel gemeenten had men té weinig oudleerlingen om er meerdere nazorginstellingen op na te kunnen houden.

Vanaf het midden van de jaren dertig waren er tekens, dat de nazorg ook landelijk verzuild zou raken. Zoals gebruikelijk kwam de aanzet hiertoe vanuit confessionele hoek. In 1935 vergaderden katholieke betrokkenen bij het BLO over de vraag, hoe een R.K. landelijke nazorgorganisatie opgebouwd zou kunnen worden. ${ }^{717}$ Er werd een commissie ingesteld, die tot taak kreeg katholieke nazorginitiatieven te bundelen in een landelijke organisatie, die dan in federatief verband zou kunnen samenwerken met andersdenkende nazorgorganisaties. ${ }^{718}$ Erg vlot liep het allemaal niet. Men kwam niet verder dan het rondsturen van een vragenlijst over de nazorg. ${ }^{719}$ Toen men de eerste stappen wilde zetten richting inhoudelijke invulling van de plannen, strooide de bezetting roet in het eten: de plannen werden na 10 mei 1940 op een laag pitje gezet. ${ }^{720}$ Voor zover valt na te gaan waren er in christelijke kring in deze periode geen plannen om tot een christelijke landelijke nazorgorganisatie te komen.

Dat in deze periode de nazorg met de verzuiling te maken kreeg, zijn aanwijzingen dat de nazorg de pioniersfase aan het ontgroeien was. Nazorg werd door de betrokkenen niet meer gezien als een gezamenlijk project waarvoor alle deskundigheid die voorhanden was gebundeld diende te worden, maar werd door een deel van hen als volwassen genoeg beschouwd om door de verschillende levensbeschouwingen verder apart ontwikkeld te worden.

\subsection{Relatie met aanverwante hulpvormen}

In de tweede paragraaf ben ik ingegaan op de inhoudelijke ontwikkelingen van het denken over zwakzinnigen bij de verschillende hulporganisaties die zich, zijdelings 
of in hoofdzaak, met zwakzinnigen bezighielden. In deze paragraaf ga ik in op de praktijk van de relatie tussen nazorg enerzijds en de belangrijkste andere hupvormen anderzijds. Nieuw hierbij is de beroepskeuze, die aan het begin van de jaren dertig een poging deed zich een plaats binnen het werkveld van de 'onvolwaardigenzorg' te verwerven.

\subsubsection{Nazorg en BLO}

Er veranderde in de jaren dertig niet veel in de relatie tussen nazorg en BLO. De afstand ertussen werd iets groter, doordat de doelgroep van de nazorg ruimer werd dan alleen oud-leerlingen van het BLO. Zo lieten in de jaren dertig een aantal werkinrichtingen oud-patiënten uit krankzinnigengestichten toe en in Amsterdam nam Pier de Bier deze groep, in samenwerking met Querido, ook op in de maatschappelijke hulp van de nazorg. ${ }^{721}$ Ook groeide het besef onder de nazorgwerkers, dat zij een aparte discipline vormden en kregen zij meer zelfbewustzijn ten opzichte van het BLO. Van Mesen, de leider van de werkinrichting in Zaandam zei hierover in 1935, op een vergadering van de NVNBO:

"Wij moeten sociaal-pedagogen worden en niet schoolmeester blijven of ons aldus voelen." ${ }^{722}$

Op praktisch niveau bleef het contact tussen BLO en nazorg bij de overgang van oud-leerlingen van school naar maatschappij nauw. Inhoudelijke veranderingen in de samenwerking deden zich op dit gebied niet voor.

$\mathrm{Bij}$ een deel van de katholieke nazorg was een beweging in omgekeerde richting te zien. Hier streefde men er nadrukkelijk naar het verband tussen BLO en nazorg te versterken in het kader van een nauw samenhangende zwakzinnigenzorg. G.A.E. Christ, directeur van 'Huize Assisië' in Udenhout en redacteur van het Tijdschrift voor R.K. BLO, schreef in 1937 over de R.K. Bond van BLO-onderwijzers:

"Ook werd begrepen, dat de taak van het B.O. slechts gedeeltelijk door het onderwijs wordt verwezenlijkt, dat de nazorg daarmee onverbrekelijk samenhangt en dat dus niet alleen het onderwijs, maar ook de nazorg en eveneens de werkinrichtingen moesten staan op het levensprogram van actie der organisatie: het ganse complex van bemoeienis der voorzorg, zorg en nazorg over het hele terrein...." ${ }^{723}$

Stond de nazorg in Breda redelijk los van de school, in Maastricht was de situatie anders. Hier was de uitvoering van de nazorg opgedragen aan een maatschappelijk werkster, H.J.M. Majoie, die in een directe hiërarchische relatie stond met de hoofden van de beide R.K. scholen voor BLO in de stad. Zij moest zich, naast de zorg voor de oud-leerlingen, ook bezighouden met het toezicht op het schoolverzuim van de leerlingen van deze scholen.

Stevige discussies tussen nazorg en BLO, zoals die zich in de jaren twintig hadden voorgedaan op het gebied van vakopleiding en arbeidsonderwijs, kwamen in de jaren dertig niet meer voor. Dat had onder andere te maken met de afstand die tussen nazorg en de organisaties voor BLO-onderwijzers was ontstaan door de oprichting van de NVNBO. Hierdoor nam het aantal contacten tussen nazorg en de onderwijzersbonden af. Het leidde er zelfs toe, dat in het midden van de jaren dertig het bestuur van O\&A besloot om nauwer met de NVNBO te gaan samenwer- 
$\operatorname{ken}^{724}$

Het idee, dat het onderwijs op het BLO zoveel mogelijk afgestemd diende te zijn op de praktijk van het leven dat oud-leerlingen van het BLO te wachten stond bleef in de jaren dertig actueel. Het BLO-schoolhoofd H.J. Jacobs schreef hierover in het gedenkboek, dat aan Van Voorthuijsen bij diens pensionering in 1937 werd aangeboden, dat hieraan nog veel te doen was:

"Zeer streng is de eis: leer zo weinig mogelijk van wat het leven niet vraagt. Daarnaast zouden we even stellig de regel willen plaatsen: leer zoveel mogelijk als het kind opnemen kan, van wat het wel behoeft." ${ }^{725}$

Veel expliciete aandacht kreeg dit punt verder niet. De economische crisis speelde daarbij een belangrijke rol. Daardoor verschoof de aandacht van de inhoudelijke ontwikkeling van het BLO en de nazorg naar het instandhouden van wat al was opgebouwd. Het ging in de jaren dertig vooral om overleven, voor andere zaken bleef amper tijd en energie over.

\subsubsection{Nazorg en sociale psychiatrie}

Gedurende de jaren dertig nam de samenwerking tussen nazorg en sociale psychiatrie toe. Psychiaters zochten, in opdracht van de gemeentebesturen voor wie zij werkten, naar methodes om de verzorging van geestelijk afwijkenden goedkoper te maken. Gestichtsverzorging moest daarbij, in verband met de hoge kosten, zoveel mogelijk worden vermeden.

Nazorgwerkers hadden een systeem van verzorging van zwakzinnigen in de maatschappij georganiseerd, dat in veel gevallen opname in een gesticht of internaat overbodig maakte. Daarom bestond er vanuit de sociale psychiatrie grote belangstelling voor de nazorg. Men beschouwde de methodiek van de nazorg als een geschikte manier waarop men ook met de eigen cliënten zou kunnen omgaan. Daarbij keek men zowel naar de maatschappelijke zorg als naar de werkinrichtingen. Nazorgwerkers hadden op hun beurt behoefte aan specifieke psychiatrische kennis bij de uitvoering van hun werk, als het bijvoorbeeld ging om de behandeling van zwakzinnigen met karakter- en omgangsmoeilijkheden of bij de beoordeling van de vraag, of nazorgpupillen ook psychiatrische problematiek vertoonden.

$\mathrm{Al}$ in de jaren twintig, tijdens het eerste Paedagogische Congres van 1926 , had Pier de Boer aangegeven dat hij graag met psychiaters wilde samenwerken, omdat nazorg en psychiatrie hetzelfde doel hadden:

"De verzorging dezer abnormalen is noch een uitsluitend medische noch een zuiver paedagogische taak. Het is mijn innige overtuiging, dat alleen door volledige samenwerking en uitwisseling van ervaringen tusschen deze beiden het doel, dat ons hier samenbrengt: 'voor de(n) abnormale zijn (haar) plaats in het leven te vinden' zal kunnen worden bereikt. ${ }^{726}$

De samenwerking verliep in de praktijk vaak erg moeizaam. Dat had te maken met de verschillende visies, die nazorgwerkers en psychiaters op hun samenwerking hadden.

Nazorgwerkers wilden samenwerken op basis van gelijkwaardigheid, elk vanuit de eigen specifieke deskundigheid. Psychiaters daarentegen beschouwden zichzelf vaak als de meerderen van nazorgwerkers. Ze voelden zich als universitair 
geschoolde artsen beter dan de schoolmeesters die zwakzinnigen hielpen en hadden de neiging om nazorgwerkers als ondergeschikten te behandelen. Dat leidde in de loop van de jaren dertig in individuele gevallen tot wrijvingen tussen psychiaters en nazorgwerkers. Dat kwam onder andere tot uiting in de discussies die binnen de NVNBO werden gevoerd over de samenwerking met de psychiatrie. In 1933 was Wepster de eerste, die deze problematische relatie aan de orde stelde, toen hij de plaatsing van ex-bewoners van krankzinnigengestichten op zijn werkinrichting categorisch afwees:

"Spreker (Wepster, LB) meent, dat samenwerking met de medici v. ontslagen gestichtspatiënten in Nazorg v. Z.Z. niet goed is. Een en ander zal gescheiden moeten blijven." ${ }^{727}$

Hij werd ondersteund door de Bredase nazorgwerker, Potters, die nadrukkelijk al te grote invloed van psychiaters op de nazorg wilde voorkomen:

"Dhr. Potters, Breda, meent ook, dat we een en ander scherp gescheiden dienen te houden, daar we anders onder de medici komen. Vandaar dat te Breda een paedagogisch bureau voor zwakzinnigen is gekomen, zoodat ze niet verwezen behoeven te worden naar de medici. ". 728

De schrik voor psychiaters bleek er twee jaar later, in 1935, nog steeds in te zitten, toen de plaatsing van oud-psychiatrische patiënten op de werkinrichtingen voor imbecillen opnieuw aan de orde kwam. Dat was in het kader van een strategische discussie over de plaats en taak van de werkinrichtingen. De Boer vond, dat opname van ontslagen bewoners van psychiatrische gestichten overwogen moest worden om te voorkomen dat er vanuit de sociale psychiatrie eigen werkinrichtingen zouden worden opgestart, zoals in Den Haag was gebeurd. ${ }^{729}$

"... het zal, willen we naast ons werk geen andere inrichtingen zien ontstaan, gewenscht zijn om K.Z. (krankzinnige, LB) patiënten, die overeenkomen met onze imbecillen op te nemen en zoo mogelijk voor de maatschappij weer klaar te maken.

Practisch blijven we als werkers baas in eigen huis en meer en meer zullen we de waarde van onze arbeidsinrichting naar buiten uitdragen. ${ }^{7730}$

Andere nazorgwerkers waren bang dat als zij samenwerking met de psychiatrie zochten, zij de zeggenschap over hun werkinrichting kwijtraakten.

"Vd Beek, Hengelo, wijst erop dat zich daar pas een psychiater gevestigd heeft, die de werkinrichting als toevluchtsoord voor zijn patiënten beschouwt. ${ }^{731}$

En bij sommigen, zoals Van der Ploeg van de christelijke werkinrichting in Rotterdam, was er ronduit sprake van afkeer van een al te nauwe samenwerking met de psychiatrie.

"Ons werk is uitsluitend om voor onze kinderen te zorgen.

De werkinrichting is het verlengstuk van onze scholen.

Zijn onze werkmeesters in staat om met K.Z. patiënten om te gaan?

'Bespaar ons de doktoren' roept spr. uit.".732

Van der Ploegs houding had vooral te maken met de voortvarende wijze waarop Pameyer, de voormalige directeur van het stedelijk krankzinnigengesticht van Rot- 
terdam en inmiddels Inspecteur voor het Krankzinnigenwezen in Noord- en ZuidHolland, ${ }^{733}$ oud-patiënten van krankzinnigengestichten wilde plaatsen op de werkinrichting van Van der Ploeg. ${ }^{734}$ Medio jaren dertig was Van der Ploeg één van de weinigen binnen de nazorg die zo'n grote afkeer van samenwerking met de psychiatrie had. Er was niet veel meer over van de huiver die begin jaren dertig nog had bestaan. De samenwerking, zo was in de praktijk gebleken, was het minst problematisch als zij in goede werkafspraken en verantwoordelijkheidsafbakeningen was vastgelegd. Als duidelijk was wat tot wiens taken en verantwoordelijkheden behoorde kon de samenwerking redelijk soepel verlopen. Zo verzorgde de Amsterdamse nazorg de maatschappelijke zorg van honderden niet-zwakzinnige geestelijk onvolwaardigen die door de afdeling Geestelijke Hygiëne van Querido naar hem waren doorverwezen. Voor deze groep was een aparte 'zuster' aangesteld, die onder directe leiding van De Boer werkte. ${ }^{735}$ Wepster legde er de nadruk op, dat het in de relatie met de psychiatrie vaak om de houding ging. Men moest zich als nazorgwerker niet al te snel laten overdonderen.

"Dat de H.H. medici imperatief optreden, daar is, als je voor je werk staat, niets van te merken. ${ }^{736}$

De NVNBO kreeg van haar leden daarom in de loop van 1935 de opdracht om te gaan onderhandelen met de Centrale Vereeniging ter behartiging van de Maatschappelijke Belangen van Zenuw-en Zielszieken over de voorwaarden, waarop expsychiatrische patiënten in de werkinrichtingen voor zwakzinnigen zouden kunnen worden toegelaten. Aan het einde van de jaren dertig werkten in vrijwel alle werkinrichtingen 'rustige' ontslagen psychiatrische patiënten. Voor drukke patiënten was geen plaats, omdat die een té ongunstige invloed op de zwakzinnigen zouden uitoefenen.

In dezelfde tijd maakte de NVNBO bekend dat zij lid van de Centrale Vereniging wilde worden. Daardoor zou de nazorgorganisatie in aanmerking kunnen komen voor bepaalde subsidies.

"Bovendien is door ons bestuur aan den Nat. Federatie voor Volksgezondheid verzocht om de Werkinrichtingen in aanmerking te doen komen voor een uitdeeling uit het Prophylaxe-fonds.

De kans op succes als zelfstandige organisatie een uitkeering te krijgen lijkt spr. (Pier de Boer, LB) zeer gering.

Mogelijk dat we door onze samenwerking met de Centr. Ver. via deze Ver. geld kunnen krijgen. ${ }^{.737}$

Daarnaast wilde men door middel van een lidmaatschap als centrale organisatie de dure individuele lidmaatschappen ${ }^{738}$ van de plaatselijke nazorgorganisaties overbodig maken. ${ }^{739}$ In Zuid-Holland was het verplicht om als nazorg lid van de Centrale Vereeniging te zijn, om voor provinciale subsidie in aanmerking te komen. Maar aansluiting mislukte: de Centrale Vereniging weigerde de NVNBO het lidmaatschap. ${ }^{740}$ Waarom dat precies gebeurde is niet duidelijk, maar het is logisch te veronderstellen dat daarbij in elk geval financiële overwegingen een rol speelden: één centrale nazorgorganisatie bracht minder lidmaatschapsgeld in dan de verschillende individuele nazorginstellingen samen. En het is niet onwaarschijnlijk te veronderstellen dat men bij de Centrale Vereniging bang was om een soort paard van Troje 
binnen te halen: de nazorgwerkers vormden een krachtig blok en stonden erom bekend dat ze daadkrachtig konden optreden. Het zou kunnen dat Meijers bang was 'zijn' vereniging aan hen kwijt te raken.

Met andere ambulante instellingen in het sociaal-psychiatrische werkveld, zoals de Medisch-Opvoedkundige Bureaux, ook bekend als 'bureaus voor moeilijke kinderen', ${ }^{741}$ bestonden geen contacten anders dan op praktijkniveau, bijvoorbeeld als het ging om verwijzingen naar elkaar. Uit een gedachtewisseling op een vergadering van de NVNBO in 1934 blijkt dat men ook geen nadere samenwerking wilde:

"vd Wouden-Delft is van meening dat we zitting moeten nemen in de bureaux $v$. moeilijke kinderen, daar er ook z.z. onder voorkomen.

De voorzitter (Pier de Boer, LB) ontraadt dit. Dit is een andere materie: als het kind z.z, is, zoo zal de leider zich van zelf met ons wel in verbinding stellen. ${ }^{.742}$

\subsubsection{Nazorg en arbeidsbemiddeling}

Tijdens de jaren dertig werden de contacten tussen nazorg er arbeidsbemiddeling intensiever, en wel op twee niveaus. Allereerst plaatselijk, met de afdelingen $\mathrm{Bij}$ zondere Bemiddeling van de Arbeidsbeurs en met de plaatselijke afdelingen van de AVO. En ten tweede op landelijk niveau, tussen NVNBO en AVO.

\section{A. Plaatselijke contacten}

In de jaren dertig kenden alleen Den Haag, Amsterdam en Nijmegen een afdeling Bijzondere Bemiddeling bij de plaatselijke arbeidsbeurs. In Amsterdam werkten deze afdeling en de nazorg volstrekt niet samen. Toch bediende deze afdeling van de arbeidsbeurs, net als de nazorg, geestelijk onvolwaardigen. Op 31 december 1935 werden 158 van de in totaal 696 cliënten van de bijzondere bemiddeling als geestelijk onvolwaardig geclassificeerd. Van deze geestelijk onvolwaardigen werden er 90 aan werk geholpen. ${ }^{743}$ Ook de nazorg bemiddelde in deze tijd geestelijk onvolwaardigen, die door de afdeling Geestelijke Hygiëne van de GG\&GD waren verwezen, naar een arbeidsplaats en begeleidde hen daarbij na plaatsing. Het ging daarbij niet om geringe aantallen. Aan het eind van 1935 betrof het in totaal 529 cliënten. ${ }^{744}$ Nazorg en bijzondere bemiddeling waren op dit punt, ondanks het feit dat ze beide gemeentelijke instellingen waren, concurrenten van elkaar.

In Den Haag was de rol van de afdeling Bijzondere Bemiddeling van de arbeidsbeurs anders. Dat kwam vooral omdat er in deze stad geen nazorg bestond. Van de 167 cliënten die in 1936 door deze afdeling aan een baan werden geholpen, waren er 115 als geestelijk onvolwaardig geclassificeerd. Van hen waren er 87 oudleerling van een school voor BLO. ${ }^{745}$

In de jaren dertig kwam er verder nog een afdeling bijzondere bemiddeling tot stand aan de Nijmeegse arbeidsbeurs, die ook een rol vervulde in de arbeidsbemiddeling van oud-leerlingen van het BLO. ${ }^{746}$

De relatie die nazorginstellingen met de plaatselijke afdelingen van de AVO hadden verschilde van gemeente tot gemeente. De verhouding kon goed zijn, zoals bijvoorbeeld in Arnhem, waar nazorgambtenaar $\mathrm{H}$. Werkhoven secretaris van de AVO-afdeling was. ${ }^{747}$ In veel gemeenten speelden nazorgwerkers een vergelijkbare rol. Er konden ook problemen zijn. Dat was bijvoorbeeld het geval in Maas- 
tricht, waar de nazorg en de plaatselijke afdeling van de AVO regelmatig meningsverschillen hadden over de plaatsing van oud-leerlingen van het BLO op de werkinrichting die door de AVO werd geëxploiteerd.

\section{B. Landelijke contacten}

De relatie met de landelijke organisatie van de AVO, Arbeid voor Onvolwaardigen, was vanaf de start van deze organisatie in 1928 problematisch. Bij de NVNBO was het wantrouwen tegen de AVO erg groot en dat zou in de loop van de jaren dertig alleen maar erger worden. In 1932, tijdens een bespreking van de gang van zaken op de werkinrichtingen voor zwakzinnigen, stelden de nazorgwerkers een brief op an het AVO-bestuur, waarin duidelijk werd gemaakt dat vertegenwoordigers van deze vereniging niet welkom waren op de bijeenkomsten van de nazorggroep. ${ }^{748}$ Toen de AVO in 1933 onderzoek liet doen naar de werkinrichtingen, besloot het bestuur van de NVNBO dit te boycotten. ${ }^{749}$ In 1938 lijkt er zelfs sprake te zijn geweest van 'bedrijfsspionage' door de AVO:

"Bestuurslid vd A.V.O. (Mr. de Paauw) wordt de inhoud vd vergaderingen vd Ver. door iemand medegedeeld. Spr. (Pier de Boer, LB) vindt dit minder geslaagd. ${ }^{7750}$

Het grote strijdpunt tussen AVO en NVNBO was de pretentie van de AVO om álle werkinrichtingen voor onvolwaardigen te vertegenwoordigen. In 1920 ging het in totaal om 20 van deze werkinrichtingen. ${ }^{751}$ Maar zes van deze inrichtingen, die waren aangesloten bij de NVNBO, lieten zich niets aan de AVO gelegen liggen en dat stak deze organisatie. Het aantal werkinrichtingen voor zwakzinnigen dat zich bij de NVNBO aansloot zou in de loop van de jaren dertig alleen maar toenemen, naar 24 in $1938 .^{752}$ De leden van de NVNBO waren unaniem van mening, dat de AVO zich niet met de werkinrichtingen voor zwakzinnigen diende te bemoeien. Het vermoeden bestond, dat de AVO er op uit was hierover zeggenschap te krijgen. Schuyt sprak dat vermoeden expliciet uit:

"De A.V.O. wil ook te Haarlem het Nazorgwerk onder zich; niet omdat het daar niet goed zou gaan, of omdat ze het beter zouden kunnen, doch om er financieel beter van te worden. ${ }^{.753}$

Een ander verwijt dat nazorgwerkers de AVO maakten was, dat het bestuur van de AVO amper voeling had met de praktijk, terwijl de NVNBO uitsluitend uit praktijkmensen bestond. Pier de Boer sprak er zich op een vergadering van de NVNBO duidelijk over uit:

"Voorzitter zegt, dat het een regentenkwestie is. Men zegt eenvoudig, dat men er namens een bepaalde groep zit en van de werkinrichtingen etc. geen verstand behoeft te hebben. ${ }^{754}$

Dit verwijt was niet helemaal terecht, omdat de AVO wel degelijk op bescheiden schaal aan concrete hulp voor onvolwaardige arbeidskrachten deed. In 1931 werd een Ambtenaar voor den Buitendienst aangesteld, die de opdracht meekreeg de arbeidsbemiddeling voor blinden, doofstommen en slachtoffers van bedrijfsongevallen ter hand te nemen. ${ }^{755}$ Dat bleek niet makkelijk te zijn:

"Vooreerst is wel gebleken dat de plaatsing van minder valide arbeiders in het gewone bedrijf groote moeilijkheden meebrengt. ${ }^{.756}$ 
Vooral het werken op landelijke schaal zal een nadeel zijn geweest, omdat het hierdoor veel moeilijker was om een netwerk van werkgevers op te bouwen die bereid waren onvolwaardige arbeidskrachten aan te nemen. Het blijkt ook uit de cijfers over het jaar 1937: van de 229 mensen die in dat jaar bij deze dienst waren ingeschreven, werden er maar 38 in werk geplaatst, een fractie van het aantal plaatsingen dat een gemiddelde nazorgambtenaar in een grote gemeente verzorgde. ${ }^{757}$ Contact met de nazorgambtenaren had deze ambtenaar voor de buitendienst niet, die zullen deze activiteit van de AVO vooral als een poging hebben gezien om de nazorg concurrentie aan te doen.

Wat verder een belangrijke rol speelde in de gespannen relatie tussen NVNBO en de AVO waren de persoonlijke tegenstellingen tussen de leden van de NVNBO en de persoon van W.F. Detiger, de secretaris-penningmeester en drijvende kracht van de AVO. Detiger werd door zijn tijdgenoten omschreven als een

"...zeer hard werkende, efficiënte man, een dictator voor zijn ondergeschikten. 'Je werd gehoond en uitgeveterd als je in zijn ogen beneden de maat gebleven was' (...) Al met al een zeer kundig ambtenaar met een formidabele werkkracht, die bovendien met enige regelmaat verfrissend helder allerlei wollig gepraat aan de kaak stelde. ${ }^{7758}$

De bestuursleden van de NVNBO wantrouwden Detiger nadrukkelijk en dat wantrouwen was wederzijds. Een rol daarin zullen zeker de grote overeenkomsten die er tussen de karakters van Detiger en de nazorgwerkers bestonden hebben gespeeld. Ze leken wat betreft werkhouding erg op elkaar en beschikten allebei over een grote deskundigheid op hun eigen werkterrein. ${ }^{759}$ De nazorgwerkers en Detiger konden hoogoplopende conflicten met elkaar uitvechten, en toch nauw met elkaar samenwerken als de nood aan de man kwam. Hierdoor groeide Detiger in de loop van de jaren dertig voor de nazorg uit tot een soort van 'dierbare vijand'.

Er speelden ook inhoudelijke geschilpunten tussen NVNBO en AVO. Belangrijkste hiervan lag in de visie op de wijze, waarop aan onvolwaardigen beschermde arbeid geboden moest worden. De AVO legde daarbij de nadruk op het belang van het bedrijfsmatige karakter van de invulling van dat werk, zoals Detiger in 1937 uiteenzette:

"Het is nodig, zowel voor betrokkenen zelf als voor de concurrentie-mogelijkheid, het gewone bedrijfsleven zo dicht mogelijk te benaderen ... exploitatie, leiding en toezicht dienen kauf-männisch te zijn ingesteld; het tempo, de bedrijfsdiscipline en de arbeidstucht dienen niet te worden verwaarloosd; de produktie voor de markt geschieden met inachtneming van de eisen, die deze markt aan kwaliteit, afwerking en prijs stelt; de economische en technische outillage dient voor die van de gewone bedrijven niet onder te doen. ${ }^{760}$

De AVO vond dat bij de afzet van producten geen beroep mocht worden gedaan op de liefdadigheidszin van de bevolking. Men wilde het liefste deze afzet gecentraliseerd laten verlopen, volgens zuiver commerciële lijnen. De Commissie-Gerzon, die hierover aan het einde van de jaren twintig in opdracht van de AVO onderzoek had gedaan en in 1930 verslag uitbracht, vond

"... het verkeerd, dat bij den verkoop der producten van fancy-fairs gebruik gemakkt wordt. Daarmee gaat (...) het ernstige karakter van den arbeid verloren. 
Het publiek moet niet uit medelijden tot koopen worden opgewekt. Dit is niet bevorderlijk voor de moreele opheffing van den onvolwaardigen. ${ }^{" 761}$

Binnen de nazorg was men het met deze opvattingen niet eens. Men beschouwde de werkinrichtingen niet als commerciële instellingen die bedrijfsmatig zouden moeten werken, maar als verpleeginrichtingen waar patiënten verbleven. ${ }^{762}$ Het doel van de werkplaatsen voor zwakzinnigen was in de eerste plaats de tewerkgestelden een dagstructurering te bieden en daardoor opname in een gesticht te voorkomen. Dat was de bestaansgrond van deze werkinrichtingen en de belangrijkste reden waarom ze door gemeenten werden gesubsidieerd. Dat het eindproduct geld opbracht was een aangename bijkomstigheid maar zeker niet het hoofddoel.

Het verschil in inzicht op dit gebied kwam het beste naar voren in Maastricht, waar de nazorg niet over een eigen werkinrichting beschikte maar pupillen op de plaatselijke $A V O$-werkplaats moest onderbrengen. De R.K. Stichting Zwakzinnigenzorg werd verplicht om voor deze pupillen een bedrag per week te vergoeden, omdat ze door hun gebrek over een té lage arbeidsproductiviteit beschikten. ${ }^{763}$ In 1939 moest 75 cent $(€ 0,32)$ per pupil per week worden bijgedragen. ${ }^{764}$

De leden van de NVNBO waren allergisch voor elke ontwikkeling die in de richting van een centraal verkoopbureau wees. Voor de afzet van hun producten waren veel werkinrichtingen afhankelijk van lokale netwerken, die nazorgwerkers met veel moeite en over langere tijd hadden opgebouwd. Dat bij die afzet, al dan niet bewust, een beroep werd gedaan op de liefdadige gevoelens van het publiek vond men geen probleem. Men wilde de opbrengst van de verkoop in financieel magere tijden niet in de waagschaal leggen door met centrale verkoop te gaan experimenteren. Schuyt was daar in 1934 duidelijk over:

"Dit zou dan de dood van de Werkinrichtingen zijn. Deze drijven op de plaatselijke sympathieën en zullen die verspelen als het landelijk gaat." 765

Naar aanleiding van het rapport van de commissie-Gerzon besloot de AVO in 1930 om een Centraal AVO-handelsbureau op te richten dat zowel de centrale inkoop van grondstoffen als de centrale verkoop van producten zou moeten gaan regelen.

"Dit bureau zal aan de instellingen, gestichten, werkplaatsen en werkverschaffingsinstellingen, die speciaal onvolwaardigen tewerkstellen, commerciële en bedrijfstechniese adviezen verstrekken, het contact met de handel en de industrie bevorderen, met de bedoeling de productie en de afzet van de door onvolwaardigen geproduceerde goederen zoo doeltreffend mogelik te organiseren. Vervolgens zal ook de centrale inkoop van grondstoffen door het bureau worden geregeld. ${ }^{766}$

De nazorgwerkers weigerden elke medewerking toen de AVO in 1932 dit bureau wilde activeren. ${ }^{767}$ Het leidde ertoe dat de plannen voor het handelsbureau mislukten, volgens de AVO

"... omdat de besturen der meeste werkplaatsen niet bereid waren zich offers te getroosten voor de installatie van het bureau en evenmin geneigd waren zich aan banden te leggen omtrent de wijze, waarop zij tot dusver de productie en den afzet had geregeld. Zelfs bleek het bij de verdere bemoeiingen van de vereeniging, dat het niet mogelijk was tot eenige afspraak te komen omtrent de prijzen, die 
door de verschillende werkplaatsen voor de vervaardigde artikelen zouden kunnen worden bedongen. ${ }^{\text {"768 }}$

Toch werkte de NVNBO in voorkomende gevallen met de AVO samen. Nazorgwerkers beschouwden de AVO wel degelijk als een belangrijke organisatie, zolang deze zich maar tot haar eigen terrein beperkte en geen pogingen deed om zeggenschap over het werkterrein van de nazorg te verkrijgen. Deze samenwerking verliep het gemakkelijkste als het om de oplossing van concrete problemen ging. Het belangrijkste voorbeeld daarvan was de cocoscrisis, die in 1934 begon. Kokos was een belangrijke grondstof omdat veel werkinrichtingen, en zeker niet alleen die voor zwakzinnigen, het vlechten van kokosmatten als belangrijkste activiteit hadden.

In 1934 verenigden de commerciële kokosfabrikanten en -importeurs zich in de Nederlandsche Cocosfabrikanten Vereeniging. Deze vereniging ging kortingen geven op de inkoop van kokos aan de eigen leden en sloot de werkinrichtingen hiervan uit. Daardoor zouden de productiekosten van kokosmatten van de werkinrichtingen oplopen, wat een gevaar voor de afzet inhield. En omdat de kokosfabrikantenvereniging het monopolie op de import van ruwe kokosvezels had, leek het erop dat het voortbestaan van de werkinrichtingen in het geding was.

De AVO stelde daarom een Commissie van Vier in, die namens alle werkinrichtingen met de kokosfabrikantenvereniging over deze problematiek moest gaan onderhandelen. Pier de Boer werd namens NVNBO lid van deze commissie, Detiger namens de AVO. De onderhandelingen verliepen moeizaam en liepen uiteindelijk helemaal stuk, de kokosfabrikantenvereniging weigerde ook maar enig water bij de wijn te doen. De Commissie van Vier besloot eind 1934 om de kokosfabrikantenvereniging links te laten liggen en voortaan zélf kokosvezels te importeren. ${ }^{769}$ Door allerlei bureaucratische problemen zou pas zes jaar later, ${ }^{770}$ begin mei 1940, het eerste schip met kokos de Amsterdamse haven binnenlopen. Veel profijt zouden de werkinrichtingen er niet van hebben, want bij de Duitse inval op $10 \mathrm{mei}$ 1940 werd het pakhuis waar de voorraad lag opgeslagen in brand geschoten. ${ }^{771}$

Problemen in de samenwerking met de AVO ontstonden vooral als ad hoc samenwerking moest worden omgezet in meer vastliggende structuren. Goed voorbeeld hiervan was het werkplaatsenverbond. Dit verbond was bedoeld om de belangen van de werkinrichtingen voor onvolwaardigen een vastere vorm te geven. De NVNBO wilde hier in principe wel aan meewerken, maar toen de nazorgwerkers eind 1935 de onder de auspiciën van de AVO opgestelde conceptstatuten van het verbond onder ogen kregen, sloeg het wantrouwen weer toe:

"Maar al te duidelijk bleek weer, dat den hr. Detiger hier mee iets in het leven wil roepen, dat geheel onder de A.V.O. staat.

Onze Ver. zal aan de Commissie van Vier uitvoerig de bezwaren melden, welke we tegen dit concept hebben. ${ }^{\text {.772 }}$

Er was een zinsnede in opgenomen die stelde dat de AVO een leidende positie in het werkplaatsenverbond innam. Die werd geschrapt. Veel verschil maakte dat uiteindelijk niet, want het werkplaatsenverbond kwam niet tot stand, omdat de werkinrichtingen die aan de gestichten waren verbonden zich terugtrokken. ${ }^{773}$

Binnen de NVNBO speelde gedurende vrijwel de gehele jaren dertig de 
vraag, of men als organisatie lid zou moeten worden van de AVO. Vooral na de afwijzing van het lidmaatschap van de Centrale Vereeniging ter Behartiging van de Belangen van Zenuw-en Zielszieken in 1937 speelde dat sterk. DE NVNBO vreesde toen in een organisatorisch isolement terecht te komen vanwege de slechte contacten die de nazorgwerkers op landelijk niveau hadden. Zo ontbraken vertegenwoordigers van de nazorg in de Staatscommissie voor de Onvolwaardige Arbeidskrachten, die over dit vraagstuk advies aan de regering moest uitbrengen. De angst bestond vooral dat hierdoor de nazorg verdeeld zou worden tussen arbeidsvoorziening voor onvolwaardigen en de sociale psychiatrie.

Toch zag men hiervan af. De angst voor overvleugeling door de AVO woog uiteindelijk toch zwaarder. ${ }^{774}$ Een poging om, in plaats van lidmaatschap, Pier de Boer in het landelijke AVO-bestuur benoemd te krijgen mislukte. ${ }^{775}$ Wel bleven vooraanstaande NVNBO-leden deel uitmaken van de verschillende ad hoc commissies van de AVO. Pas met het uitbreken van de Tweede Wereldoorlog in september 1939, toen de economische situatie voor de werkinrichtingen erg dreigend werd, besloot men dan toch maar de moeilijke stap te zetten en het lidmaatschap van de AVO aan te vragen. De Boer merkte hierover op 4 mei 1940 op, dat

"... samenwerking, los van persoonlijke gevoelens, nu een dwingende eis is."

Maar de gebeurtenissen in de meidagen van 1940 haalden deze ontwikkeling in: Nederland raakte betrokken bij de Tweede Wereldoorlog en de situatie voor de nazorg veranderde daardoor volkomen. Aansluiting bij de AVO was daardoor niet langer actueel.

\subsubsection{Nazorg en beroepskeuze}

Aan het begin van de jaren dertig kreeg de nazorg kort te maken met nieuwe concurrentie op het gebied van de zorg voor onvolwaardigen, in de vorm van de Bureaux voor Beroepskeuze. Deze bureaus bestonden in enkele gemeenten, onder andere Amsterdam, Tilburg en Den Haag en waren in de loop van de jaren twintig ontstaan. Het doel ervan was, alle kinderen die van de lagere school afkwamen te adviseren bij het vinden van een geschikt beroep en hen vervolgens te helpen bij het zoeken naar werk.. ${ }^{777}$

De betrokkenen bij de beroepskeuze vonden dat het werk van de nazorgambtenaren tot hún takenpakket behoorde. De directeur van het Haagse bureau voor beroepskeuze, G. Koning, formuleerde dat in 1930 als volgt:

\footnotetext{
"Er is geen grond deze nazorg alleen te organiseeren voor oud-leerlingen der buitengewone scholen, al vormen deze wel een groote groep afzonderlijk. Alle hulpbehoevenden komen o.i. hier voor deze nazorg in aanmerking met inachtneming van zoowel een groot verschil in zorg voor elke categorie als in die voor elk kind individueel. Het Gemeente-Bureau voor Beroepskeuze is o.i. de aangewezen instelling om de nazorg op het terrein der beroepskeuze en beroepsopleiding voor alle hulpbehoevenden uit te oefenen., ${ }^{778}$
}

In Amsterdam probeerde het Bureau voor Beroepskeuze een voet tussen de deur van de zorg voor onvolwaardigen te krijgen. In 1930 richtte het bureau een afdeling voor 'jeugdige onvolwaardigen' op en ging daarmee de concurrentie aan met zowel de nazorg als de Afdeling Bijzondere Bemiddeling van de arbeidsbeurs. Dat bleek 
een stap te ver. Onder invloed van de gevolgen van de economische crisis besloot het Amsterdamse gemeentebestuur kort daarna om het gehele Bureau voor Beroepskeuze op te heffen. ${ }^{779}$

Pier de Boer ging de discussie met de beroepskeuzeadviseurs rechtstreeks aan in hun eigen blad, Jeugd en Beroep. Hierin had hij aan het einde van de jaren twintig een reeks artikelen gepubliceerd over de methodiek van de nazorg. Hij begon een polemiek met E.J. van Det, oprichter en tot 1929 directeur van het Amsterdamse Bureau voor Beroepskeuze, ${ }^{780}$ waarin De Boer de stelling verdedigde, dat de zorg voor zwakzinnigen en normalen niet op dezelfde basis mocht gebeuren:

"De Nazorg voor zwakzinnigen heeft zijn eigen problemen, vaak verwant met die van de normalen, soms daarmede parallel loopend, maar in wezen daarvan verschillend, omdat het andere individuen betreft; de nazorg heeft daarom ook zijn eigen verzorgingsnorm, die niet zonder meer op de normale jeugd kan worden toegepast."

Door de opheffing van het Bureau voor Beroepskeuze in Amsterdam heeft deze nooit een echte bedreiging van de nazorg kunnen zijn. In Den Haag, waar het Bureau voor Beroepskeuze haar voortbestaan in de jaren dertig wél wist veilig te stellen, lag dat anders. Het is redelijk te veronderstellen, dat de late aanstelling van een nazorgambtenaar voor een deel te verklaren valt door het bestaan van dit bureau, dat net als de arbeidsbeurs probeerde een graantje mee te pikken van de onvolwaardigenzorg. 


\title{
Ondanks alles door blijven werken
} 1940-1945

\author{
"Volhardt en blijf ook het volgend jaar op de bres staan." \\ Wethouder Westerveld van Haarlem op de vergadering \\ van de NVNBO op 28 december 1940
}

Dit hoofdstuk wijkt door de gevolgen van de bezetting die op 10 mei 1940 begon, nogal af van het voorafgaande. De omstandigheden tijdens de bezettingsjaren bepalen, veel meer dan in de voorafgaande hoofdstukken, de indeling van dit hoofdstuk.

Ik begin met de eerste gevolgen van de bezetting en de reactie daarop van de nazorg. Vervolgens ga ik in op de gelijkschakeling, de pogingen van de bezetter om de Nederlandse samenleving in nationaal-socialistische zin te veranderen. Daarna bespreek ik de ingrepen van de bezetter op het gebied van de arbeidsbemiddeling en daarmee samenhangend de Arbeitseinsatz, de pogingen van de bezetter om Nederlandse arbeidskrachten in te zetten voor de Duitse oorlogsindustrie. Ik ga dan over op de oprichting van een residentiële instelling van zwakzinnigen door De Boer, een rapport over oud-leerlingen van het BLO door Van Voorthuijsen en de zorgen die binnen de nazorg en de hulpverlening in het algemeen heersten over de toestand van de jeugd, in het bijzonder van de zwakzinnige jeugd. Hierna behandel ik het ontstaan van de voogdij voor zwakzinnigen, gevolgd door het gevaar dat eind 1944 voor oud-leerlingen van het BLO ontstond vanuit nationaalsocialistische hoek. Ik sluit af met de bevrijding en de eerste ontwikkelingen daarna.

In dit hoofdstuk komen alle onderzoeksvragen aan de orde.

\subsection{Tien mei 1940 en daarna}

De Duitse inval op 10 mei 1940, de daaropvolgende vlucht van regering en koningshuis naar Engeland, het rampzalige verloop van de strijd, de bombardementen op Rotterdam en Middelburg en de overgave van de Nederlandse strijdkrachten op 18 mei betekenden voor de gehele Nederlandse bevolking een enorme schok. De nazorgwerkers probeerden, net zoals de meeste Nederlanders, hiermee om te gaan door het beste te maken van de nieuwe situatie. Het motto was 'doorgaan onder gewijzigde omstandigheden', ook voor de nazorg. Wepster omschreef het gevoel dat direct na de nederlaag tegen de Duitsers heerste:

"Met goeden moed, maar niet geheel gerust, hervatten we na de bange oorlogsdagen onzen arbeid en ziet ... het viel mee! $!^{782}$

Maar de gevolgen van het oorlogsgeweld konden niet worden ontkend. In Rotterdam was bij het bombardement op die stad de werkinrichting van Willeboer, die in het centrum van de stad had gelegen, geheel verwoest. De overige nazorginstellingen begonnen in de zomer van 1940 met een inzameling van geld en grondstoffen. Mede daardoor kon de Rotterdamse werkinrichting in augustus 1940 op een nieuwe locatie de werkzaamheden alweer hervatten. ${ }^{783}$ 
Een ander gevolg van de Duitse inval was de vernietiging van pas binnengekomen kokosvoorraad in de Amsterdamse haven. Hierdoor werden alle werkinrichtingen direct geconfronteerd met een ernstig grondstoffentekort. De NVNBO eiste de overgebleven kokosvoorraden voor zichzelf op, omdat het voor haar werkinrichtingen bijzonder moeilijk zou zijn om vervangende werkzaamheden te vinden. $\mathrm{Zij}$ zou met deze kokosvoorraden nog een jaar toekunnen. De AVO, die de kokosvoorraad beheerde, besloot om voorlopig ook de andere werkinrichtingen van kokosvezel te blijven voorzien. De nazorgwerkers waren bang, dat ze zo binnen twee maanden geen grondstoffen meer zouden hebben.

"Dit is funest en onredelijk, want het vervaardigen van cocosmatten is voor onze werkinrichtingen een noodzakelijk iets, daar deze patiënten te eenzijdig [zijn] om dit werk te kunnen missen. ${ }^{784}$

De AVO ging hier niet op in en de kokosvoorraad was binnen korte tijd opgebruikt. In januari 1941 werd het gebruik ervan door het Rijkstextielbureau, dat de schaarse grondstoffen in de textielindustrie verdeelde, verboden. ${ }^{785}$ De nazorgwerkers hadden echter hun eigen inventiviteit onderschat. Ze bleken erg creatief te zijn in het vinden van vervangende werkzaamheden voor het vlechten van kokosmatten. Geen van de werkplaatsen hoefde de deuren te sluiten vanwege een gebrek aan grondstoffen. In Schiedam ging men voortaan biezen matten maken, in Gouda werd sisalafval verwerkt en in Amersfoort stapte men over op het verzagen van bomen en het maken van bezems van heide. ${ }^{786}$ In Utrecht werd montagewerk verricht voor een fabriek en in Rotterdam werden restanten touw uitgeplozen om de vezels opnieuw te kunnen gebruiken. ${ }^{787}$

De NVNBO besprak de nieuwe omstandigheden op een spoedvergadering, eind augustus 1940. Daarbij werd duidelijk, dat door het conflict over de kokosgarens de relatie met de AVO op een dieptepunt was aangeland. Er kwam een overleg tussen Detiger en de NVNBO, waarin alle irritaties uit de jaren dertig samenkwamen en tot een heftige uitbarsting leidden. Het bestuur van de NVNBO verweet Detiger té weinig voeling met de praktijk te hebben, Detiger probeerde op zijn beurt een vertegenwoordiger van de AVO in het bestuur van de NVNBO te krijgen. Dat leidde tot een stevige reactie van de zijde van de NVNBO:

"er moet niemand in ons bestuur, doch de menschen v.d. practijk moeten in de A.V.O., dan komt de hr. Detiger van zelf beter op de hoogte. ${ }^{788}$

Het leek er op, dat zowel Detiger als het bestuur van de NVNBO zich niet realiseerden dat er intussen wel een bezetting aan de hand was.

Dat de nazorg (samen met het BLO) een naïeve houding ten opzichte van de bezettingsautoriteiten had, bleek uit de pogingen van nazorg en BLO om, onder de 'gewijzigde omstandigheden' de centrale registratie van oud-leerlingen eindelijk eens te regelen. Wat in de jaren daarvoor nooit mogelijk was geweest, lukte nu ineens wel. Begin 1941 nam de Adviescommissie voor Zwakzinnigen van de AVO, waarin onder andere Christ van het katholiek BLO, De Jeu namens O\&A en De Boer en Schuyt voor de NVNBO zitting hadden, het besluit om deze registratie op poten te zetten. 
"Bij een bespreking in deze commissie besloot men tot het instellen van leerlingstaten, welke staten met de leerlingen meeverhuizen en uiteindelijk op een centraal bureau in Utrecht terecht komen. Op deze staten zullen aantekeningen voorkomen inzake: karakter, milieu, onderwijs en arbeidsgeschiktheid van een leerling." ${ }^{789}$

De gegevens van de oud-leerlingen werden ondergebracht op het kantoor van de Inspectie van het BLO in Utrecht en werden beheerd door de opvolger van Van Voorthuijsen, I.C. van Houte. Zo was er dan eindelijk de gegevensbank van alle oud-leerlingen van het BLO in Nederland gekomen, waar de NVNBO al vanaf het begin van de jaren dertig naar had gestreefd.

\subsection{Gelijkschakeling}

$\mathrm{Al}$ vrij snel na het begin van de bezetting namen de Duitse bezettingsautoriteiten een aantal maatregelen die tot doel hadden de Nederlandse samenleving in nationaal-socialistische zin te veranderen. Als één van de eerste sectoren werd daarvan de liefdadigheid het slachtoffer. Eind augustus 1940 werd besloten, dat voor elke inzamelingsactie voortaan een vergunning van de overheid nodig was. In de praktijk werden deze niet meer verleend. Eind oktober werd de Winterhulp opgericht, naar het voorbeeld van de Duitse Winterhilfe, die alleen 'arische' doelen ondersteunde. Zij mocht uiteraard wél geld inzamelen. Tegelijkertijd werd het de pers verboden, enig artikel over particuliere liefdadigheidsinstelling te publiceren. ${ }^{790} \mathrm{De}$ particuliere liefdadigheid werd van inkomsten en publiciteit beroofd en daarmee feitelijk uitgeschakeld. De Winterhulp kreeg hierdoor het monopolie over de Nederlandse liefdadigheid.

Binnen de NVNBO ontstond de angst, dat ook de hulpverlening zou worden gecentraliseerd en onder nationaal-socialistische invloed zou worden geplaatst. Pier de Boer maakte er in mei 1941 op een bijeenkomst van de NVNBO een opmerking over.

"We weten, wat er op het gebied van de weldadigheid gebeurd is, doch weten nog niet, wat er met onze Ver. en stichtingen zal gebeuren." ${ }^{791}$

Daarbij keken de betrokkenen bij nazorg en BLO nadrukkelijk naar de ontwikkelingen in Duitsland, waar in de loop van 1934 alle BLO-organisaties waren opgenomen in de nationaal-socialistische onderwijzersbond. ${ }^{792}$ Het leidde ertoe dat men in BLO-kringen probeerde de bezetter een stap voor te zijn, door zélf de organisaties voor BLO alvast te centraliseren. Zo hoopte men te voorkomen dat deze onder nationaal-socialistisch toezicht zou worden geplaatst. Men streefde naar de oprichting van een federatie, waarbij naast de organisaties voor BLO-onderwijzers ook de vakbonden voor onderwijzend personeel aangesloten moesten worden. Van Voorthuijsen was de drijvende kracht hierachter. Hij spande zich erg in om de federatie van de grond te krijgen.

"In moeilijke tijden kan een organisatie, die op de bres staat voor doelmatige zorg aan misdeelden, niet worden gemist. Er bestaat alle hoop, dat de autoriteiten bij het nemen van maatregelen te rade zullen gaan bij de federatie, die thans een zoveel vastere vorm heeft aangenomen. ${ }^{793}$

Het lukte hem om eind december 1940 een bestuur benoemd te krijgen. ${ }^{794}$ Maar 
binnen de organisaties die van de federatie deel zouden moeten uitmaken bestond allesbehalve consensus over nut en noodzaak van een dergelijke instelling. Vooral binnen O\&A was er verzet. Pier de Boer en E.P. Schuyt speelden daarin, begin 1941, een hoofdrol.

"Schuyt (Haarlem) houdt een warm pleidooi voor $\mathrm{O}$. en $\mathrm{A}$. als algemene vereniging voor het buitengewoon onderwijs in Nederland voor alle richtingen. Hij laakt het optreden van de federatie, waarschuwt daartegen en wil, dat $O$. en $A$. zich zal terugtrekken uit deze federatie. 0 . en $\mathrm{A}$. moet alleen een paedagogische vereniging zijn; voor vakbelangen moeten de leden naar de grote vakorganisaties. ${ }^{.795}$

Toen de meerderheid van de leden besloot om de deelname van O\&A aan de federatie te handhaven, trad het afdelingsbestuur van Haarlem in zijn geheel af en trok E.P. Schuyt zich terug als landelijk penningmeester. Kennelijk maakte dit indruk, want kort daarna trok de vereniging zich terug uit de federatie. ${ }^{796}$ Niet lang daarna werd de federatie in zijn geheel opgeheven. Dat had niet zozeer te maken met het afhaken van O\&A, alswel met de maatregelen die de bezetter nam ten opzichte van de vakbeweging. In de loop van 1941 werden de Nederlandse vakbonden gedwongen samengevoegd in het Nederlandsch Verbond van Vakverenigingen (NVV), de socialistische bond die voor dit doel onder nationaal-socialistische leiding was gebracht. ${ }^{797}$ Onderwijsvakbonden als de Bond van Nederlandsche Onderwijzers en het Nederlandsch Onderwijzers Genootschap vielen hierdoor af als leden van de federatie. De bond voor R.K. BLO vond dat daardoor de basis van de federatie te smal was geworden en stapte eruit. Kort daarna werd het restant van de federatie ontbonden. ${ }^{798}$

De NVNBO was buiten de federatie gebleven. Zij bleef tijdens de bezetting het enige landelijke samenwerkingsorgaan van de nazorg. Ook de katholieke BLO-bond, die eind jaren dertig begonnen was met de voorbereidingen voor de oprichting van een landelijke R.K. nazorgorganisaties, erkende de NVNBO voor de duur van de bezetting als hét orgaan voor landelijk nazorgoverleg.

Voor zover valt na te gaan bleef de NVNBO gedurende de gehele bezetting buiten het blikveld van de bezetter. Er zijn geen aanwijzingen dat er pogingen zijn ondernomen om de organisatie te liquideren, zoals dat met veel andere verenigingen en stichtingen wél is gebeurd.

\subsection{Arbeidsbemiddeling}

Op het gebied van de arbeidsbemiddeling kreeg de nazorg wél te maken met ingrijpen door de bezetter. Deze wilde de arbeidsbemiddeling centraal kunnen aansturen. In de Arbeidsbemiddelingswet van 1930 was die centrale sturing nadrukkelijk weggelaten, het primaat bleef bij de gemeenten liggen. Het ministerie van sociale zaken had graag een centrale rol gespeeld, maar daarin was in de wet niet voorzien. ${ }^{799}$ Toen Nederland in 1940 werd bezet, hoopte men bij het departement van sociale zaken $^{800}$ van de nieuwe omstandigheden gebruik te kunnen maken om die centrale sturing van de arbeidsbemiddeling alsnog te kunnen invoeren. ${ }^{801}$ De bezetter was daartoe bereid. Aan het einde van september 1940 werd de gemeentelijke arbeidsbemiddeling afgeschaft en kwam de verantwoordelijkheid ervoor te liggen bij het Rijksarbeidsbureau, een nieuwe afdeling van het departement van sociale zaken. Onder het Rijksarbeidsbureau vielen 37 Gewestelijke Arbeidsbureaus (GAB's), die 
over in totaal 143 bijkantoren beschikten in kleinere gemeenten. ${ }^{802}$

Deze besluiten hadden ook voor de nazorg grote gevolgen. De gewestelijke arbeidsbureaus kregen het monopolie over de arbeidsbemiddeling. Andere organisaties, dus ook de nazorg, mochten er zich niet langer mee bezighouden. Daarmee dreigde één van de belangrijkste onderdelen van het nazorgwerk verloren te gaan. Om dat te voorkomen ging het bestuur van de NVNBO in mei 1942 in overleg met de verantwoordelijke ambtenaren op het departement voor sociale zaken. Pier de Boer vroeg daarvoor nadrukkelijk de toestemming van zijn collega's.

"Wij vragen U dan ook goedkeuring om met het Departement v. Sociale Zaken om hierover overleg te plegen opdat de oud I.I. v/h B.O. niet bij de arbeidsbeurzen worden ondergebracht. We kunnen dan mogelijk de moeilijkheden opvangen. De districtsarbeidsbeurzen zijn er alleen voor de arbeidsbemiddeling en de verdere zorg voor onze oud-I.I. moet aan ons B.O. blijven, zoodat het sociale toezicht voor ons blijt." ${ }^{803}$

Bij deze onderhandelingen speelde de pas aangestelde Haagse nazorgwerker, Van Dijk, een belangrijke rol. Hij zat dicht bij het vuur en kon daardoor gemakkelijk op departementaal niveau contacten leggen en onderhouden. Hierdoor lukte het om tot een pragmatische oplossing te komen. De nazorgwerkers kregen officieel géén toestemming om aan arbeidsbemiddeling voor hun pupillen te blijven doen. In plaats daarvan kregen zij formeel een functie bij de arbeidsbureaus, waar zij werden aangesteld met de opdracht de arbeidsbemiddeling voor alle oud-leerlingen van het BLO in hun district te verzorgen. Hierdoor konden de nazorgambtenaren hun werk vrijwel onveranderd voortzetten.

Over deze kwestie ontstond opnieuw wrijving met de AVO. Deze had, zonder de nazorgwerkers er in te kennen, aan het departement van sociale zaken voorgesteld om de nazorg voor zwakzinnigen, min of meer in aansluiting op de aanbevelingen van de Staatscommissie voor de Onvolwaardige Arbeidskrachten, onder háár invloed te plaatsen. ${ }^{804}$ Hiervoor had zij geen gehoor gekregen maar de relatie met de NVNBO werd er door deze actie niet beter op, zoals blijkt uit een opmerking die Pier de Boer op een vergadering van de NVNBO in mie 1941 maakte.

"De opzet is, dat we krijgen een Centraal orgaan (dus een algemeen adviesbureau voor zwakzinnigen) met correspondenten in de plaatsen en die belasten zich met de Nazorg voor zoover er niet in is voorzien. 't Leek ons nuttig, dat $U$ op de hoogte bent. Wij willen een plaatselijke organisatie met bezorgde krachten." ${ }^{805}$

In vergelijking met de jaren dertig werd de arbeidsbemiddeling er voor de nazorgwerkers onder de bezettingsomstandigheden een stuk makkelijker op. Arbeidskrachten waren schaars geworden, zodat nazorgpupillen een ruime keuze hadden uit mogelijke baantjes. Ook de moeilijker plaatsbare oud-leerlingen konden aan het werk. Wepster maakte hiervan melding in het jaarverslag van de Dordtse nazorg over 1942:

"Tengevolge van de groote vraag naar werkkrachten, doet zich verder het feit voor, dat enkele patiënten voor wie het tot nu toe onmogelijk was, een plaatsje in het vrije bedrijf te verkrijgen, thans wel in de termen vallen." ${ }^{806}$

Aanvankelijk zag men alleen de positieve kant van deze ontwikkeling, maar naar- 
mate de bezetting vorderde maakten nazorgwerkers zich steeds meer zorgen over de vraag hoe het met de nazorgpupillen zou gaan als de bezetting voorbij was. $\mathrm{Ze}$ verwachtten dat dan de vooroorlogse verhoudingen weer zouden terugkeren:

"Nu ontvangen zij loonen, die ver boven hun prestatie liggen. Het zal zeer de vraag zijn, of zij zich in de toekomst weer gelukkig zullen gevoelen in het oude milieu der Stichting. Wij voorzien met hen nog wel moeilijkheden." ${ }^{807}$

\subsection{Arbeitseinsatz}

Al snel na het begin van de bezetting werd duidelijk waarom het Duitse bezettingsbestuur zo hartelijk had meegewerkt aan de centralisatie van de Nederlandse arbeidsbemiddeling. Duitsland had grote behoefte aan arbeidskrachten om de oorlogsindustrie draaiende te houden en de Duitse mannen die in het leger waren opgenomen te vervangen. De bezetter wilde hiervoor de Nederlandse werklozen inzetten. In het Duitse bezettingsbestuur werd hiervoor een aparte organisatie opgezet bij de Hauptabteilung Soziale Verwaltung, die het departement van sociale zaken controleerde. De Arbeitseinsatzverwaltung ${ }^{808}$ werd opgericht met als taak om zoveel mogelijk arbeidskrachten te werven voor tewerkstelling in Duitsland. Deze organisatie kreeg op elk gewestelijk arbeidsbureau een vertegenwoordiger, een Fachberater, die ervoor moest zorgen dat zoveel mogelijk werklozen uit zijn district naar Duitsland werden gezonden. Daarnaast werd aan elk arbeidsbureau een Geneeskundige Afdeling verbonden, die Nederlandse werklozen moest keuren op geschiktheid voor uitzending naar Duitsland. Het merendeel van de artsen die hier werkten was Nederlands en veelal afkomstig van de plaatselijke GG\&GD2 8 tittzending van Nederlandse werklozen naar Duitsland kende in 1940 een geschiedenis van tien jaar. Vanaf 1930 bestond er een Nederlandse arbeidsbeurs in het Ruhrgebied, in Oberhausen. Plaatsing in Duitsland gebeurde toen op basis van vrijwilligheid. Vanaf 1938 konden werklozen, op straffe van intrekking van de steun, verplicht worden in Duitsland te werken. ${ }^{810}$ Die dwang verviel bij het uitbreken van de Tweede Wereldoorlog in $1939,{ }^{811}$ om de neutraliteit van het Koninkrijk niet in gevaar te brengen. Dat besluit werd op 24 mei 1940 door het departement van sociale zaken weer teruggedraaid. Werk in Duitsland werd vanaf die datum voor Nederlandse werklozen opnieuw als 'passende arbeid' beschouwd. ${ }^{812}$

In de zomer van 1940 werd begonnen met een grote operatie, waarbij alle 200.000 geregistreerde werklozen gekeurd moesten worden. Van deze groep werd er uiteindelijk $44 \%$ geschikt bevonden voor uitzending. In februari 1942 werkten er 165.000 Nederlanders in Duitsland. ${ }^{813}$

Ook nazorgwerkers kregen met deze ontwikkelingen te maken, doordat er onder de geregistreerde werklozen oud-leerlingen van het BLO voorkwamen. Ook zij werden gekeurd en liepen kans om naar Duitsland te worden uitgezonden. In 1941 maakte Majoie, de Maastrichtse nazorgwerkster, hiervan melding op een vergadering van de NVNBO.

"Mej. Majoie zegt, dat het te Maastricht niet steeds gelukt om de B.O. I.I. niet naar Duitschland te sturen." ${ }^{814}$

Op deze opmerking werd door haar collega's opvallend behoedzaam gereageerd. 
"Voorzitter, Arnhem en Haarlem wijzen er op, dat in de plaatsen waar Nazorgambtenaren zijn geen moeilijkheden ontstaan. Te Den Haag heeft men een speciale kaart v/d B.O. I.I. Door de ambtenaren wordt rapport uitgebracht aan de afd. Jeugdbemiddeling en als het goede debielen betreft met geen bijzondere afwijkingen dan adviseert men daar - met goedvinden van Ouders en Jongen - om uitzending naar Duitschland mogelijk te maken." ${ }^{815}$

Dat had waarschijnlijk eerder met zelfcensuur van de notulist, E.P. Schuyt, te maken dan met datgene wat er daadwerkelijk op deze vergadering is besproken. Publicaties van direct na de bevrijding geven een ander beeld. Nazorgwerkers verklaarden daarin, dat zij zich tijdens de bezetting hadden ingezet om uitzending van oud-leerlingen van het BLO naar Duitsland te voorkomen, soms met het risico om in conflict te komen met de bezettingsautoriteiten. De Haagse nazorgwerker G.H. van Dijk schreef in zijn eerste jaarverslag van na de bevrijding over

" ... den grooten afweerstrijd tegen de Nazipropaganda, welke bij de zwakzinnigen en psychopathen met hun suggestiebele karakters een maar al te vruchtbaren voedingsbodem vond." 816

Die propaganda droeg er toe bij dat sommige oud-leerlingen zich vrijwillig voor uitzending meldden. Hen werd nadrukkelijk afgeraden dit te doen. Als het om oudleerlingen uit NSB-gezinnen ging, moest er voorzichtig worden opgetreden.

Er werd ook geprobeerd om de oud-leerlingen van het BLO als groep in z'n geheel ongeschikt te laten verklaren voor uitzending naar Duitsland. Van Dijk maakte hierover afspraken met het Haagse arbeidsbureau. Hij reisde zelfs naar Duitsland, om met de arbeidsbureaus dáár afspraken te maken over het weigeren van oud-leerlingen van het $\mathrm{BLO}^{817}$ Ook Bodaan in Rotterdam ondernam dergelijke pogingen. ${ }^{818}$ Geheel zonder gevaar was een dergelijke handelwijze niet. Van Dijk werd bijvoorbeeld in totaal vijf maal door de bezettingsautoriteiten over zijn rol bij uitzendingszaken verhoord. ${ }^{819}$

Naarmate de oorlog voor Duitsland slechter verliep en meer Duitse steden en industrieën door geallieerde bombardementen werden beschadigd nam de druk toe om meer Nederlanders naar Duitsland te sturen. In 1943 werd de totale oorlog uitgeroepen. Nederland zou vanaf september 1943 per maand 15.000 arbeidskrachten naar Duitsland moeten sturen. In januari 1944 werd dat streefcijfer verhoogd naar 21.000 per maand, ${ }^{820}$ maar in de eerste zes maanden van dat jaar werden slechts 15.000 arbeidskrachten naar Duitsland overgebracht in plaats van de geëiste $126.000 .{ }^{821} \mathrm{Na}$ D-day en de gedeeltelijke bevrijding van Nederland in septemberoktober 1944 schakelde de bezetter over op het gebruik van geweld. Er werden razzia's gehouden, waarbij willekeurig mannen werden opgepakt, gekeurd en vervolgens naar Duitsland gestuurd. Op 10 en 11 november gebeurde dat in Rotterdam, waar 50.000 mannen werden opgepakt. Den Haag was op 21, 22 en 23 november aan de beurt. Hier ging het om in totaal 13.000 mannen. Daaronder waren 25 nazorgpupillen, waarvan er uiteindelijk 7 in Duitsland terecht kwamen. Op 6 december volgde een razzia in Haarlem, op 9 december gevolgd door Delft. ${ }^{822}$ In januari 1945, toen de situatie voor Duitsland al hopeloos was geworden, viel het besluit dat alle Nederlandse mannen van 16 tot 40 jaar in Duitsland moesten gaan werken. Nazorgpupillen werden hiervan nadrukkelijk niet uitgesloten. Zij moesten, net als alle anderen, door Duitse artsen op arbeidsgeschiktheid worden gekeurd. 
Van Dijk stuurde uit protest hiertegen een vijftigtal imbecille jongens en mannen naar de keuring. Dat leidde ertoe dat alle nazorgpupillen alsnog van uitzending werden vrijgesteld. ${ }^{823}$

\subsection{Een dubieus rapport}

Van Voorthuijsen, de gepensioneerde BLO-inspecteur, bleef zich ook na de mislukking van de federatie bemoeien met het BLO, de nazorg en de zwakzinnigenzorg in het algemeen. In 1941 schreef hij in opdracht van het voormalige Ministerie van Onderwijs, Kunsten en Wetenschap, dat gedurende de bezetting was omgedoopt tot Departement van Opvoeding, Wetenschap en Cultuurbescherming, het RAPPORT over een onderzoek naar het milieu der leerlingen van de Haagse scholen voor Buitengewoon Onderwijs. ${ }^{824}$

Het handelde in hoofdzaak over het oorzakelijke verband tussen zwakzinnigheid en pauperisme. Met het rapport wilde Van Voorthuijsen definitief aantonen, dat zwakzinnigheid tot pauperisme leidde. Daarbij ging hij er van uit, dat erfelijkheid bij het ontstaan van zwakzinnigheid een belangrijke rol speelde. ${ }^{825}$

Voor het onderzoek had hij de ouders van de leerlingen van twee scholen voor BLO en van twee scholen voor gewoon lager onderwijs met elkaar vergeleken. Van elk soort school was er één gekozen, die door kinderen uit de laagste volksklasse werd bezocht en één door kinderen uit een beter milieu. ${ }^{826}$ Van Voorthuijsen had zelf enkele gezinnen bezocht, maar het grootste deel van het onderzoek had hij laten uitvoeren door de onderwijzers van de scholen, aan de hand van vragenlijsten die hij had opgesteld. Daarnaast had hij de dossiers van onderzochte ouders bij de armenraad ingezien.

In het onderzoek kwamen onderwerpen aan de orde als aanraking met de armenraad, het beroep van de vaders, ongewenste toestanden in het gezin (gezinnen met buitenechtelijke kinderen of ongehuwde ouders) en de vraag, of er sprake was van een gedwongen huwelijk, wat volgens Van Voorthuijsen zo was als er binnen 7 maanden na het huwelijk van de ouders een kind geboren was. Het leidde tot de volgende conclusies:

"Als resultaten van het onderzoek mag, naar het mij voorkomt, worden vastgesteld:

$1^{\mathrm{e}}$. dat de leerlingen der scholen voor zwakzinnigen voor een groot deel worden gerecruteerd uit de onderste lagen der maatschappij;

2e. dat in het bijzonder vele leerlingen afkomstig zijn uit de alleronderste laag der samenleving;

3e. dat in de gezinnen der b.o.-leerlingen, veelvuldiger dan in gezinnen met uitsluitend normale kinderen, allerlei afwijkingen en misstanden worden aangetroffen, die op de opvoeding een nadelige invloed uitoefenen;

4e. dat de verstandelijke minderwaardigheid bij de b.o.-leerlingen in zeer veel gevallen gepaard gaat met psychopathische karaktertrekken, welke zich openbaren in afwijkingen van het gedrag der kinderen in en buiten de school;

5e. dat er derhalve een duidelijk aanwijsbaar verband bestaat tussen ongunstige levensomstandigheden en geestelijke misdeeldheid." ${ }^{827}$

Van Voorthuijsen kreeg precies die uitkomsten van zijn onderzoek, die hij wilde hebben. Dat wordt bijzonder duidelijk in zijn opvattingen over het verband tussen zwakzinnigheid en werkloosheid: 


\begin{abstract}
"Bij het bestuderen van de dossiers heb ik sterk de indruk ontvangen, dat de langdurige en tevens de telkens zich herhalende werkloosheid voor een groot deel is toe te schrijven aan de geestelijke ongeschiktheid van vele mensen om in de tegenwoordige maatschappij op eigen benen te staan. (...) Dit wil dus zeggen, dat de oorzaak van de werkloosheid in vele gevallen gelegen is in de werkloze zelf en dat de behandeling moet beginnen met een juist inzicht in de persoonlijkheid van het individu. Voor de werkers in het buitengewoon onderwijs zijn dit geen onbekende klanken. ${ }^{828}$
\end{abstract}

Hij ging ook in op het verband tussen criminaliteit en zwakzinnigheid en haalde daar het Haagse nazorgrapport uit 1930 opnieuw voor aan, waaruit was gebleken dat $23,5 \%$ van de onderzochte oud-leerlingen in aanraking was geweest met politie of justitie: ${ }^{829}$
"Bij het onderzoek, dat in de jaren 1928 en 1929 te 's-Gravenhage is verricht om- trent de toestand, waarin zich de ontslagen leerlingen der openbare en der bij- zondere scholen voor buitengewoon onderwijs bevonden, is het gebleken, dat een groot deel der oud-leerlingen met de politie en met de justitie in aanraking was geweest." 830

Van Voorthuijsen diepte dit onderwerp verder uit, door te onderzoeken in hoeverre de vaders van de leerlingen in de voorgaande tien jaar gevangenisstraf hadden gekregen. Hij ontdekte, dat $13,1 \%$ van de vaders van de BLO-leerlingen detentie hadden ondergaan, tegen $6,9 \%$ van de vaders van leerlingen van het gewoon lager onderwijs. ${ }^{831}$
"Alles wijst er op, dat de neiging tot het verrichten van criminele handelingen juist in de gezinnen met zwakzinnige kinderen veelvoudig wordt aangetroffen. Vele zwakzinnigen groeien derhalve op in een milieu van wangedrag en misdaad, het meest ongunstige milieu, dat zich voor de opvoeding laat denken. ${ }^{1832}$

Hij concludeerde, dat het gezinsleven bij de meeste oud-leerlingen van het BLO niet veel voorstelde. Hij schreef dat toe aan

"... het feit, dat de op de scholen geplaatste zwakzinnigen veelal voortkomen uit de gezinnen der proletariërs. Allerlei omstandigheden maken, dat het gezinsleven bij deze groep der samenleving op een lager peil staat dan dat bij de betere klassen der maatschappij het geval is. ${ }^{\text {"833 }}$

Bovendien trok hij de conclusie, dat de intellectuele capaciteiten van de meeste ouders van BLO-leerlingen erg klein waren.

\begin{abstract}
"Veel meer dan over ouders, die buitengewoon onderwijs hebben genoten, wordt in de lijsten gesproken van ouders, die de gewone lagere school niet ten volle hebben afgelopen. (...) Van een groot aantal andere ouders wordt meer in het algemeen vermeld, dat zij op school niet konden leren of dat de briefjes, die naar de school worden gezonden, het bewijs leveren, dat althans het taal- en het schrijfonderwijs zeer onvoldoende resultaten hebben opgeleverd." ${ }^{1834}$
\end{abstract}

Daarbij ging hij niet in op de suggesties van de leerkrachten die het onderzoek uitvoerden, dat omgevingsfactoren een belangrijke rol speelden bij het slechte gedrag van hun leerlingen:

"Er bestaat bij de leerkrachten een sterke neiging om slechte gedragingen bij voorkeur toe te schrijven aan ongunstige milieu-factoren. In vele gevallen wordt 
bij de vermelding van psychopathische karaktertrekken tevens gewezen op de verwaarlozing, waaraan de kinderen zijn blootgesteld. ${ }^{1835}$

Wat het rapport van Van Voorthuijsen bijzonder maakte, waren niet de opvattingen die hij erin ventileerde. Die waren sinds het begin van de jaren dertig niet wezenlijk veranderd. Belangrijker waren de cryptische beleidsaanbevelingen die hij aan het eind van het rapport deed:

"Het is nuttig en nodig, dat allerlei maatregelen worden genomen om de nadelen voor de getroffen individuën zoveel mogelijk af te wenden en tevens om de maatschappij in haar geheel te vrijwaren voor de schade, welke door de aanwezigheid van de groep der geestelijk misdeelden wordt veroorzaakt." ${ }^{836}$

Van Voorthuijsen was uitstekend op de hoogte van de sterilisatiewetten, die in Duitsland vanaf 1934 van kracht waren. ${ }^{837}$ Het lijkt er op dat hij, in navolging van vele anderen, van de bezetting wilde profiteren om omstreden maatregelen die onder democratische omstandigheden in Nederland niet haalbaar waren geweest alsnog in te voeren. Dat durfde hij alleen niet expliciet op te schrijven. Ik ga er overigens niet van uit dat hij verdergaande maatregelen tegen zwakzinnigen bepleitte, zoals deze in het geheim in Duitsland werden doorgevoerd. In paragraaf 7.8 zal ik hierop dieper ingaan.

\subsection{Zorgen om zwakzinnigen}

\subsubsection{Criminaliteit}

Tijdens de bezettingsjaren maakte men zich in de Nederlandse hulpverlenende gemeenschap steeds grotere zorgen over de toestand van de jeugd als geheel. Tijdens de bezettingsjaren leek de Nederlandse jeugd te zijn losgeslagen. I.C. van Houte, de inspecteur van het BLO, besteedde in 1941 aandacht aan dit probleem in het Tijdschrift voor Buitengewoon Onderwijs.

"Men is vast besloten met de beschikbare middelen krachtig op te treden tot beteugeling van het kwaad ener verwilderde jeugd. ${ }^{838}$

De cijfers met betrekking tot de jeugdcriminaliteit gaven inderdaad ten tijde van de bezetting een forse stijging te zien. In 1939 waren er bijna 3200 minderjarigen voor de kinderrechter gebracht, in 1943 was dat meer dan verdubbeld tot 7400 . In het grootste deel van de gevallen ging het daarbij om diefstal, al dan niet in groepsverband gepleegd. ${ }^{839}$ Dat het daarbij om 'stelen uit honger' ging, werd ontkend: dat zou tot aan de hongerwinter van 1944 op 1945 amper zijn voorgekomen. De toegenomen jeugdcriminaliteit werd vooral toegeschreven aan de ineenstorting van het morele systeem in Nederland. Het onderscheid tussen recht en onrecht was onder de bezettingsomstandigheden niet langer duidelijk, waardoor ook de grens tussen gewenst en ongewenst gedrag vervaagde. Wat vroeger crimineel was, kon nu ineens als een daad van verzet worden gezien.

Daarbij ontstond er, door de schaarste aan allerlei producten, een levendige informele economie, waarin op grote schaal de distributiemaatregelen werden ontdoken. Gestolen waar kon zonder al te veel risico op de zwarte markt worden afgezet.

Deze situatie werd verergerd door de grote problemen waarmee het on- 
derwijs tijdens de bezetting te kampen kreeg, vooral op het gebied van de huisvesting. Veel schoolgebouwen, ook van het BLO, werden door de bezetter gevorderd. Scholen moesten alternatieve huisvesting zoeken en waren door het ruimtegebrek vaak gedwongen om de lestijden aanzienlijk te bekorten. Jongeren kregen daardoor veel meer vrije tijd dan voorheen en hadden geen mogelijkheden om deze zinvol in te vullen.

Vanaf najaar 1943 maakte een commissie van de Nationale Federatie voor de Geestelijke Volksgezondheid, waarvan onder andere K.H. Bouman deel uitmaakte, in alle stilte plannen om na de bevrijding deze problematiek aan te pakken. ${ }^{840}$

Ook in het BLO en de nazorg maakte men zich hierover buitengewoon veel zorgen. De angst voor de verkeerde aanleg van zwakzinnigen, die onder ongunstige omstandigheden tot ontwikkeling zou kunnen komen, werd actueel door de dramatische verslechtering van de sociale omstandigheden in de loop van de bezetting. Van Houte schreef:

\begin{abstract}
"Nu is een deel der jeugd - en wij kennen dat deel van zeer nabij - door zijn bijzondere geaardheid als het ware voorbestemd om door de ongunstige omstandigheden te worden gegrepen. Een beperkter waarnemingsvermogen, een ongebreidelde fantasie, een onvoldoende beoordeling, sterk egoïstische neigingen, een verhoogde sexualiteit, een zwak moreel besef en nog tal van andere ongunstige eigenschappen meer, werken onder de gegeven omstandigheden het misdrijf in de hand.".841
\end{abstract}

Binnen de nazorg bezon men zich op middelen om onder deze moeilijke omstandigheden zwakzinnigen in een betere, gecontroleerde sociale omgeving te brengen. Daarvoor werden verschillende wegen bewandeld, die op het eerste gezicht niet bij de nazorg pasten. Ik zal ze in min of meer chronologische volgorde behandelen.

\title{
7.6.2 Huize Vechtoever
}

Opvallend was het initiatief van Pier de Boer, die in 1941 een debieleninternaat voor jongens begon in Huize Vechtoever te Maarssen, een kapitale achttiendeeeuwse villa aan de Vecht. Het lijkt geheel in tegenstelling te zijn met het werk en de inzet van De Boer in de voorafgaande jaren. Uit de doelstelling van het internaat blijkt, dat het in eerste instantie ging om de bescherming van een groep zwakzinnigen die ernstig gevaar liep om sociaal af te glijden. Vechtoever richtte zich vooral op nazorgpupillen die werkloos waren en in een kosthuis of pleeggezin waren ondergebracht. Zij ontbeerden dagbesteding en beschikten niet meer de beschikking over de 'natuurlijke rem' die het eigen gezin voor hun handelen betekende.

\footnotetext{
"Het internaat (...) zou een groote vooruitgang beteekenen wat de verzorging betreft, voor een aantal gevallen, welke thans in gezinsverpleging zijn en thans overdag elke regelmatige bezigheid missen. Aan dit internaat zou een werkmogelijkheid voor de pupillen verbonden moeten zijn. Daarnaast zou een betere verzorging gevonden worden voor vele gevallen, welke thans dubbele verzorging noodig hebben, n.l. plaatsing in gezinsverpleging en plaatsing op de arbeidsinrichting." 842
}

De Boer ving ook andere groepen zwakzinnigen op. Vanaf de oprichting functioneerde Vechtoever als een soort doorgangshuis voor Amsterdamse zwakzinnigen die uit gestichten kwamen en moesten wennen aan het leven in de grote stad. De 
eerste zes bewoners waren afkomstig van de Rekkense Inrichtingen.

Wat Vechtoever anders maakte dan de andere kleinschalige zwakzinnigeninternaten, was de nadruk die De Boer legde op handhaving van het contact met de eigen sociale omgeving. In september 1940 omschreef De Boer het als een internaat met weekend-mogelijkheid:

"Nieuw zou zijn, dat door de ligging van het internaat de geplaatste pupillen, die voornamelijk uit Amsterdam afkomstig zullen zijn, in de gelegenheid zouden kunnen worden gesteld door een weekend-verblijf in Amsterdam de nog bestaande familiebanden te onderhouden. ${ }^{843}$

Onder invloed van de oorlogsomstandigheden veranderden in de loop van de bezetting de redenen waarom een zwakzinnige op Vechtoever terecht konden. De voedingstoestand werd een plaatsingsindicatie. Was deze slecht, dan kon de nieuwe bewoner op Vechtoever bijgevoed worden. ${ }^{844}$

De Boer begon zijn internaat met vijf bewoners. Hun aantal zou in de loop van de bezetting tot 40 oplopen. ${ }^{845}$ Van hen keerden er nog tijdens de bezetting 21 terug naar hun gezin van herkomst, negen bewoners vestigden zich na het vinden van een baan vanuit Vechtoever zelfstandig in Amsterdam. ${ }^{846}$

\subsubsection{Werkkamp voor debielen}

Onder de zwakzinnigen was één groep, die de nazorgwerkers buitengewoon veel zorgen baarde. Dat waren de debiele psychopaten, oud-leerlingen van het BLO die ernstige karakter- en gedragsmoeilijkheden vertoonden. Zij waren, nóg meer dan 'gewone' zwakzinnigen, gevoelig voor slechte invloeden uit hun omgeving. Zij gleden tijdens de bezetting buitengewoon snel en ernstig maatschappelijk af.

In de loop van de bezetting verergerde de problematiek van deze groep in die mate, dat men zich binnen de nazorg bezon op radicale maatregelen. Op 19 januari 1944 vergaderde de NVNBO over de

"....inrichting van een werkkamp voor debielen, waar gevallen uit het geheele land kunnen worden ondergebracht." ${ }^{.847}$

Het grootste probleem met de debiele psychopathen was, dat ze niet adequaat aangepakt konden worden, zoals dat vóór de bezetting wel mogelijk was geweest.

\footnotetext{
"De gevallen, die spr. (E.P. Schuyt, LB) op het oog heeft, kan hij via de Kinderrechter niet onder controle krijgen, daar de straf door gebrek aan ruimte in de inrichtingen, toch niet toegepast kan worden. Hadden we zoo'n kamp, dan zou hij die gevallen snel berecht kunnen zien door den Kinderrechter met de bepaling, dat ze in dat kamp v. debielen geplaatst zouden moeten worden. ${ }^{8648}$
}

De gestichten hadden, net als zoveel andere instellingen, veel gebouwen aan de bezetter moeten afstaan, waardoor hun capaciteit aanzienlijk was gedaald. Het werkkamp dat de nazorgwerkers wilden stichten was bedoeld als een noodvoorziening om in het ontstane plaatsgebrek te voorzien.

Het was vooral aan G.H. van Dijk, de Haagse nazorgambtenaar, te danken dat het werkkamp uiteindelijk zou worden gerealiseerd. Hij maakte gebruik van zijn goede contacten bij het departement van sociale zaken om het kamp binnen handbereik te brengen. 
In het kamp konden 50 tot 60 mannelijke pupillen tussen 18 en 35 geplaatst worden, die er minimaal een half jaar zouden verblijven. Hun rantsoen zou, als ze zich voldoende inzetten, worden verdubbeld. De kosten van de inrichting en de plaatsing van het kamp kwamen voor rekening van het Rijk.

Het was nadrukkelijk de bedoeling dat plaatsing in het kamp als straf zou dienen voor de betrokken nazorgpupillen, 'al noemen we het niet zo', ${ }^{849}$ zoals Pier de Boer het uitdrukte. Plaatsing in het kamp werd beschouwd als een voorschot op de maatschappelijke verhoudingen van na de bezetting. De nazorgwerkers vreesden dat de materiële omstandigheden van de nazorgpupillen dan zouden terugvallen naar het niveau van de jaren dertig.

"Momenteel is er volop werk doch na den oorlog zullen zeker onze debielen weer in het gedrang komen. Nu hebben ze loonen van f $20,--f$. 70 ,- per week en die gaan er na den oorlog uit en zullen [ze] weer een nieuw leger van eeuwige steuntrekkers vormen. ${ }^{.850}$

De AVO beheerde kampen die wat de doelstelling betreft vergelijkbaar waren met het beoogde nazorgkamp, onder andere in Oss en Hummelo. Ze waren echter niet uitsluitend gericht op zwakzinnigen. De Boer had geprobeerd een dergelijk kamp te bezoeken, maar Detiger had geweigerd hem toe te laten. Schuyt had informatie over deze kampen ingewonnen, waaruit hij concludeerde dat de omstandigheden er té slecht waren om er oud-leerlingen van het BLO in onder te brengen. Dat had te maken met de kwaliteit van de voedselvoorziening en de samenstelling van de populatie.

"De diensten v. Maatsch. Hulpbetoon maken er handig gebruik van om de eeuwige steuntrekkers, die alle onvolwaardigen geworden zijn, er heen te sturen en dus vrij van ondersteuningsgelden te komen. Dit kamp is langzamerhand een kamp voor ouden $v$. dagen geworden en stellig ongeschikt voor onze debielen." ${ }^{851}$

Dat het onder de nationaal-socialistische bezetting wel eens gevaarlijk zou kunnen zijn om zoveel problematische zwakzinnigen bij elkaar onder te brengen, werd slechts door een enkeling te berde gebracht. G.J. van der Ploeg, de leider van de christelijke werkinrichting in Rotterdam was de enige die op een mogelijk risico wees:

"Vd Ploeg, R'dam moet niets van dwang hebben. Bovendien is hij voor het op een kluitje zetten van zwakzinnigen, die veel last veroorzaken, bevreesd, zoolang we hier niet zelf de baas zijn. Op deze wijze spelen we ze in de kaart. Ze zijn dan geregistreerd en gesteriliseerd enz. kon er gemakkelijk het gevolg van zijn. ${ }^{8552}$

De overige nazorgwerkers deelden deze zorg niet. De Boer wees erop, dat in dit opzicht de scholen voor BLO eigenlijk véél gevaarlijker waren.

"Voorzitter zegt, dat we die dwang als verzorgingsmaatregel moeten zien. Het gevaar van het bijeenbrengen van zwakzinnigen deelt spr. en de vergadering niet. In dat geval zouden onze buitengewone scholen een veel groter gevaar kunnen zijn. ${ }^{.853}$

Uiteindelijk gingen de leden van de NVNBO unaniem akkoord met het werkkamp voor debielen, óók Van der Ploeg. De voorbereidingen werden met de voor na- 
zorgwerkers zo kenmerkende voortvarendheid aangepakt. Van Dijk, De Boer en Schuyt overlegden met het departement van sociale zaken over de verdere invulling van de plannen. Het kamp zou op 26 februari 1944 geopend worden in Giesbeek, aan de IJssel in Oost-Gelderland. ${ }^{854}$

De NVNBO had echter buiten de AVO gerekend. Detiger tolereerde op het gebied van werkkampen geen concurrentie, zoals eerder de Almelose nazorgwerker had ondervonden.

"V. Beek zegt, dat men voor Twente ook zoo'n kamp wilde en dat er eerst veel ${ }_{855}^{k}$ kan op inwilligen bestond, doch dat Detiger ook dit van de baan gewerkt had."

Detiger wist door gebruik te maken van zijn contacten bij de Rijksdienst voor de Werkverruiming de opening van het nazorgkamp op het allerlaatste moment tegen te houden.

Opnieuw leidde het tot een hoogoplopend conflict tussen het bestuur van de NVNBO en Detiger, waarbij de plaats van handeling ditmaal het kantoor van Detiger op het AVO-hoofdkwartier te Amsterdam was. De Boer, Schuyt, Wepster, Werkhoven en Van Dijk bestonden het de bijeenkomst uit te roepen tot een bestuursvergadering van de NVNBO, waarbij Detiger als gast aanwezig was.

"Hiertegen verzet de heer Detiger zich in eerste instantie, doch legt er zich ten slotte bij neer." 856

De Boer wilde van Detiger weten, waarom hij de opening van het werkkamp had tegengehouden.

"De voorzitter zegt allereerst van den heer Detiger te willen vernemen, waarom hij de opening van ons kamp te Giesbeek onmogelijk heeft gemaakt. Fel keert hij zich tegen dit optreden (...) en laakt het ten zeerste, dat de hr. Detiger zonder met onze ver. welke aangesloten is bij de AVO, overleg te plegen, dit plan heeft getorpedeerd. ${ }^{n 5}$

Detiger maakte duidelijk dat de AVO het monopolie op werkkampen voor onvolwaardigen bezat en dat de vereniging niet van plan was om dit op te geven.

"De AVO heeft alleen kampen voor onvolwaardigen en àls er al een kamp voor asociale debielen moet komen zal dit ook een AVO-kamp zijn en dan is er over te praten, of de Ver. Nazorg al of niet ingeschakeld moet worden." 858

De onwrikbare houding van Detiger op dit punt wekte veel irritatie bij de nazorgwerkers.

"De Boer zegt, dat het niet tegen de AVO gaat, doch tegen den persoon Detiger, die zonder rekening te houden met de belangen onzer debielen, alles omverwerpt, omdat hij vooral dictator wil spelen. ${ }^{859}$

Veel leverde het gesprek niet op. Detiger bleef vasthouden aan het alleenrecht op werkkampen voor onvolwaardigen. Als de NVNBO er op stond, konden de nazorgwerkers betrokken worden bij de oprichting van een werkkamp voor debielen, maar de AVO zou er de eindverantwoordelijkheid voor dragen. De nazorgwerkers waren niet bereid aan zo'n constructie mee te werken. Beide partijen gingen uiteen zonder ook maar een millimeter nader tot elkaar gekomen te zijn. Allebei kondig- 
den ze aan dat ze met de Rijksdienst voor de Werkverruiming zouden gaan overleggen. $^{860}$

Uiteindelijk kwam het werkkamp voor debielen er tóch, zonder dat de AVO er zeggenschap over kreeg. Het werd als kamp De Vanenburg in de loop van 1944 in de buurt van Putten op de Veluwe geopend. ${ }^{861}$ Het lijkt er dus op, dat de NVNBO uiteindelijk de strijd met de AVO had gewonnen, maar door een gebrek aan bronnenmateriaal is dat niet helemaal duidelijk geworden. Overigens is het kamp op het nippertje ontsnapt aan ontruiming door de Duitsers. Toen eind oktober 1944 nabij Putten een Duitse officier door het verzet werd gedood, werden alle mannelijke bewoners van deze gemeente afgevoerd naar concentratiekampen en veel huizen in het dorp vernietigd. De Vanenburg lag juist buiten het gebied waar deze maatregelen doorgevoerd werden. ${ }^{862}$

\subsection{Voogdij}

In 1942 werd zowel in Amsterdam als Den Haag begonnen met het verzorgen van de voogdij voor oud-leerlingen van het BLO. Dat gebeurde in beide steden op initiatief van de nazorgambtenaren, De Boer in Amsterdam en Van Dijk in Den Haag. Dat deze beide initiatieven juist tijdens de bezetting werden genomen, wil niet zeggen dat ze direct samenhingen met de bezettingsomstandigheden. Het opstarten van voogdij-instellingen die zich specifiek richtten op zwakzinnige kinderen had vooral te maken met een problematiek die al in de jaren twintig speelde en eind jaren dertig acuut was geworden.

In hun praktijk kwamen nazorgwerkers regelmatig kinderen tegen die zich in een gezinssituatie bevonden, die als zó slecht werd beschouwd, dat zij ingrijpen op grond van de kinderwetten noodzakelijk achtten. De ondertoezichtstelling, waarbij ouders het gezag over hun kind moesten delen met een gezinsvoogd was de minst ingrijpende en de meest toegepaste maatregel. De meeste nazorginstellingen voerden deze gezinsvoogdij uit. Maar als ontheffing van of ontzetting uit de ouderlijke macht, waarbij ouders de zeggenschap over hun kinderen geheel verloren, noodzakelijk werd geacht, ontstond er een probleem dat in grote lijnen al in de jaren twintig bekend was:

"Het is $U$ bekend, dat de procedure tot ontzetting en ontheffing van ouders of voogden niet tot een goed eind kan worden gebracht, wanneer niet een instelling van kinderbescherming of een particulier bereid wordt gevonden, de zorg voor de kinderen over te nemen. Nu is het juist bij het vinden van die opvolgende voogdij, dat de Voogdijraden in de laatste vijf, zes of zeven jaren in het bijzonder op groote moeilijkheden stooten." ${ }^{863}$

Deze problemen hadden een financiële oorzaak: het Rijk betaalde voor alle kinderen die onder voogdij waren geplaatst - en die daarom gewoonlijk regeringskinderen werden genoemd - dezelfde vergoeding. Voor zwakzinnige en anderszins gehandicapte kinderen moesten echter vaak extra kosten worden gemaakt, die samenhingen met hun gebrek. Hiervoor moest dan apart subsidie worden aangevraagd, de zogenaamde suppletiegelden, bij de gemeente waar de voogdij-instelling gevestigd was. Gemeenten voelden daar maar weinig voor en deden, zeker in de moeilijke jaren dertig, hun uiterste best om aan deze betalingen te ontkomen. ${ }^{864}$ Voor veel voogdijverenigingen was dat een belangrijke reden om zwakzinnige kinderen te 
weigeren. Een andere reden om de voogdij over zwakzinnige kinderen niet over te nemen had ermee te maken, dat aan deze kinderen vaak aanzienlijk meer tijd besteed moest worden dan aan niet-zwakzinnige kinderen. Gevolg van de weigerachtigheid van voogdijverenigingen was, dat het voor de kinderrechter in de praktijk niet mogelijk was om ouders van zwakzinnige kinderen uit de ouderlijke macht te ontzetten.

Om een einde te maken aan deze door de nazorg als ongewenst beschouwde toestand, werden er al aan het einde van de jaren dertig door nazorgwerkers plannen gemaakt om de zaak zélf in handen te nemen en een eigen voogdijvereniging op te richten. De Boer in Amsterdam en Van Dijk in Den Haag gebruikten daar allebei een particuliere organisatie voor. In Amsterdam was dat de AGO, die de werkinrichtingen voor oud-leerlingen van het BLO exploiteerde en in Den Haag de Vereniging Schroeder van der Kolk, een organisatie die zich vooral bezighield met de maatschappelijke integratie van psychisch gestoorden maar ook zwakzinnigen tot haar doelgroep rekende. Beide organisaties namen in de loop van 1940 een nieuwe doelstelling in hun statuten op, die het mogelijk maakte ook als voogdijvoorziening op te treden.

In Amsterdam ${ }^{865}$ begon De Boer de Afdeling Voogdij van de AGO met 24 kinderen, in de loop van de bezetting zou hun aantal toenemen tot $63 .{ }^{866}$ Door zijn goede contacten met het gemeentelijke apparaat werden de suppletiegelden zonder problemen uitbetaald. Hij voerde het voogdijwerk zelf uit en plaatste het grootste deel van de kinderen die onder zijn verantwoordelijkheid vielen in Amsterdamse pleeggezinnen. $^{867}$

\subsection{Toenemende dreiging: Rotterdam}

De grootste bedreiging voor oud-leerlingen van het BLO tijdens de bezetting ontstond in Rotterdam, in het voorjaar van 1944. De dreiging kwam uit nationaalsocialistische hoek. Het hoofd van de Afdeling voor Erfelijkheidsonderzoek van de Rotterdamse GG\&GD, die tijdens de bezetting onder leiding van een NSB-er stond, vroeg toen om inzage in het kaartregister waarin de gegevens van alle oudleerlingen van het BLO waren vastgelegd en dat bij de Inspectie van het BLO in Utrecht berustte. ${ }^{868}$ Het register was, zoals in paragraaf 7.1 besproken, in 1941 op initiatief van nazorg en BLO aangelegd. ${ }^{869}$

De zaak werd met de inspecteur van het BLO,-Van Houte, besproken. Bij die gesprekken was ook de radicale nationaal-socialist M.M. Rost van Tonningen betrokken ${ }^{870}$ Het Nederlandse episcopaat bereidde zich voor op een eventueel ingrijpen om het ergste te voorkomen. ${ }^{871}$ Dat was uiteindelijk niet nodig, omdat Van Houte besloot om eigenhandig een einde aan de dreiging te maken. Samen met enkele medewerkers vernietigde hij het register en dook vervolgens onder. ${ }^{872}$ Toen de geallieerden met de invasie van Normandië de bevrijding van West-Europa inluidden, richtte de bezetter zich volledig op de strijd en hield zich niet meer bezig met de Nederlandse oud-leerlingen van het BLO. Het verdere verloop van de oor$\log$ zou ervoor zorgen, dat die dreiging werd afgewend.

Desondanks was de situatie precair geweest. Zwakzinnigen behoorden in de nationaal-socialistische ideologie tot de overbodige menselijke ballast, waartoe onder andere ook joden, zigeuners en homoseksuelen behoorden. In Duitsland werd 
vanaf het einde van de jaren dertig een programma voor de Vernichtung Lebensunwertes Leben uitgevoerd, waardoor uiteindelijk zo'n 100.000 mensen waren gedood. ${ }^{873}$ Het was de meest vérgaande doorvoering van de eugenetische principes die mogelijk was.

In Nederland had men geen enkel idee van het gevaar dat zwakzinnigen onder de Duitse bezetting liepen. Bij nazorg en BLO bestond evenmin enig besef van de risico's die aan de registratie van oud-leerlingen zou kunnen kleven onder een nationaal-socialistisch bewind. Het inzicht dat die gegevens niet alleen ten goede konden worden gebruikt ontbrak volledig. Pas ná de bevrijding zag men de parallellen die er bestonden met de behandeling van de joden.

\begin{abstract}
"Het was na de waarschuwing, die de behandeling der Joden inhield (...) de vraag in hoeverre de rassenwaan als deel van de Duitse ideologie tenslotte ook zou worden toegepast op de Nederlandse bevolking, met name op de zwakzinnigen. Het lag geheel in de lijn van de maatregelen van de bezetter, dat ook deze bevolkingsgroep een aanval zou hebben te doorstaan. ${ }^{.874}$
\end{abstract}

Voor zover bekend zijn in Nederland geen zwakzinnigen naar de vernietigingskampen afgevoerd enkel vanwege hun zwakzinnigheid. Ook zijn er geen zwakzinnigen op eugenetische gronden gesteriliseerd. Er zijn wél duizenden zwakzinnigen in de concentratiekampen omgekomen, waarheen zij waren afgevoerd vanwege hun joodse afkomst.

Van één zwakzinnigeninternaat zijn tijdens de bezetting vrijwel alle bewoners en personeelsleden gedood. Dat was internaat Achisomog, dat net als de naastgelegen psychiatrische kliniek Het Apeldoornsche Bosch een joodse instelling was. Beide instellingen werden in 1943 door de bezetter ontruimd. Er werden toen 1200 personen naar de vernietigingskampen getransporteerd. ${ }^{875}$

\title{
7.9 Oorlog en bevrijding: chaos en opnieuw beginnen.
}

Vanaf het najaar van 1944 was Nederland oorlogsgebied. De chaos en verwoesting waren veel groter dan in de meidagen van 1940. Het land raakte gesplitst in twee delen. Het zuiden werd nog voor de inval van de winter bevrijd, maar het gebied ten noorden van de grote rivieren moest nog tot aan het voorjaar van 1945 wachten totdat de bezetter verdreven was. Het westen van het land makkte met de hongerwinter de moeilijkste tijd van de bezetting door.

Zelfs onder de meest barre omstandigheden zetten de nazorgwerkers hun werk voort. De gang van zaken in Dordrecht is daarvan een goed voorbeeld. Tot september 1944 draaide de werkinrichting van Wepster normaal door. Toen vorderde de Duitse Wehrmacht de gebouwen voor militair gebruik. De werkinrichting verhuisde naar de imbecillenschool, en functioneerde daar totdat op 24 oktober 1944 dat gebouw door een bombardement zwaar werd beschadigd. Toen werden de werkzaamheden, onder doorbetaling van lonen en zakgelden, stilgelegd. Maar al op 3 februari 1945, nog vóór de bevrijding van de stad, ging de jongenswerkinrichting alweer open, op 1 april gevolgd door de weefkamer. Pas na 5 mei kon de draad weer helemaal worden opgepakt. ${ }^{876}$

In de periode tussen 1938 en 1947, de beide jaren rondom de bezetting waarin het Centraal Bureau voor de Statistiek gegevens verzamelde, groeide de nazorg. In hoeverre deze groei tijdens de bezetting gebeurde of in de jaren daar 
direct voor en na, valt niet meer na te gaan. In 1938 werd nazorg in negen gemeenten verzorgd, in 1947 ging het om 16 plaatsen. De oud-leerlingen van 62 op een totaal van $171 \mathrm{BLO}$-scholen konden gebruik maken van de diensten van een nazorginstelling, tegen 58 op 138 scholen $^{877}$ in 1938. Het aantal werkinrichtingen nam minder spectaculair toe. Haar aantal steeg van 25 in 1938 naar 32 in $19477^{878}$ In 1947 waren er in totaal 708 personen in de werkinrichtingen tewerkgesteld. ${ }^{879}$ Bij de nazorg stonden er in dat jaar 17.869 mensen als cliënt ingeschreven. Van hen waren er 13.645 oud-leerlingen van een school voor BLO ${ }^{880}$ Gezien de laatstbekende vooroorlogse cijfers van het totale aantal pupillen van nazorg, uit 1937, toen er sprake was van een totaal van 4814 nazorgpupillen, waarvan er 3658 van het BLO stamden, ${ }^{881}$ is de groei van het aantal nazorgpupillen in deze periode spectaculair geweest. Het is zeer waarschijnlijk, dat hun aantal ook tijdens de bezettingsjaren fors is blijven stijgen. De verdrievoudiging van het aantal pupillen kan niet alleen in de jaren direct ná de bezetting hebben plaatsgevonden.

De bevrijding betekende een wezenlijke verandering voor de nazorg. De pionierstijd was voorbij. Veel nazorgwerkers van het eerste uur waren tijdens of direct na de bevrijding weggevallen. In 1940 al was Frantsen uit Vlaardingen met pensioen gegaan. Van der Wouden uit Delft overleed plotseling aan het begin van 1944. Op 28 oktober 1945 stierf ook Pier de Boer, de Amsterdamse nazorgwerker en voorzitter van de NVNBO. ${ }^{882}$ Zijn dood kwam bijzonder hard aan onder zijn colleganazorgwerkers. .

"Door het overlijden van De Boer verliest niet alleen de nazorg te Amsterdam zijn stuwende kracht, doch ook de vereniging mist nu een voorzitter, die bijkans niet te vervangen is." ${ }^{883}$

E.P. Schuyt volgde De Boer op als voorzitter van de NVNBO en Van Dijk, de Haagse nazorgwerker, werd de nieuwe secretaris van de vereniging. Wepster uit Dordrecht ging in 1947 met pensioen ${ }^{884}$ en alleen E.P. Schuyt en H. Werkhoven uit Arnhem haalden in hun functie als nazorgambtenaar het vijfentwintigjarig jubileum van de NVNBO in 1957. De NVNBO was op dat moment niet langer het centrale orgaan van de nazorg in Nederland, maar één van de drie organisaties van nazorginstellingen, naast een katholieke en een protestantse. 


\section{Hoofdstuk 8 \\ Discussie en conclusie}

In dit afsluitende en samenvattende hoofdstuk probeer ik, in de eerste paragraaf, een antwoord te geven op de onderzoeksvragen zoals ik me die in de inleiding heb gesteld. In de tweede paragraaf probeer ik de hoofdpunten weer te geven van wat ik in de voorgaande hoofdstukken heb behandeld en een antwoord te geven op mijn hoofdvraag, in hoeverre de nazorg heeft bijgedragen aan de integratie van zwakzinnigen in de Nederlandse maatschappij.

\subsection{Discussie}

\subsubsection{De doelgroep van de nazorg}

De eerste deelvraag waarop ik een antwoord probeer te geven luidt: hoe zag de doelgroep van de nazorg eruit en welke verschillende subgroepen werden door de nazorg hierbinnen onderscheiden?

Gedurende de gehele periode die mijn onderzoek bestrijkt waren oudleerlingen van het BLO de belangrijkste doelgroep van de nazorg. Van al deze oudleerlingen werd verondersteld, dat zij een licht verstandelijk gebrek hadden. Of dat daadwerkelijk het geval was is de vraag. De test van Binet en Simon, in de Nederlandse aanpassing van Herderschêe, werd als maatstaf gebruikt om vast te stellen of iemand zwakzinnig was. Daarvoor was deze test echter niet bedoeld. De test stelde alléén vast, of een kind in staat was om het einddoel van het gewoon lager onderwijs te halen. ${ }^{885}$ Het was een selectiemiddel ten behoeve van de toelating van kinderen tot het BLO. Of iemand al dan niet zwakzinnig was, kon men er niet direct uit afleiden. Binnen het BLO en de nazorg werd de test wél als zodanig beschouwd. Bovendien zag men de uitkomst als een onveranderbaar, vastliggend gegeven. 'Eéns zwakzinnig, altijd zwakzinnig' werd er gezegd en als iemand ooit het stempel 'zwakzinnig' had gekregen, kwam deze er vrijwel niet meer vanaf.

Een groot percentage van de oud-leerlingen van het BLO kon zich zonder verdere hulp heel goed in de maatschappij redden. Volgens De Boer ging het hierbij in 1923 om $35 \%$ van zijn cliënten. ${ }^{886}$ In 1932 had hij het over ongeveer $40 \%$ van zijn nazorgpupillen, die 'zeker zullen slagen' ${ }^{887}$ Deze hoge percentages zijn deels te verklaren door het feit dat een aantal kinderen op de scholen voor BLO niet zwakzinnig was. Daarnaast ontwikkelde een deel van de oud-leerlingen van het BLO zich intellectueel verder en was daardoor, ook volgens de destijds geldende maatstaven, niet langer zwakzinnig. Volwassenen waren zwakzinnig, indien zij niet in staat waren om zich zelfstandig in de maatschappij te handhaven vanwege een verstandelijk gebrek. ${ }^{888}$ Dat betekent, dat ongeveer éénderde van alle oudleerlingen van het BLO uiteindelijk niet meer als zwakzinnig kon worden geclassificeerd. ${ }^{889}$

Niet alleen oud-leerlingen van het BLO vormden de doelgroep van de nazorg. Al vrij snel na de start richtte men zich ook op andere groepen. In Haarlem betrok men aanvankelijk de subnormalen, kinderen die de gewone lagere school niet hadden voltooid, bij de nazorg. ${ }^{890}$ De nazorg hielp in vrijwel alle gemeenten waar zij bestond ook zwakzinnigen die geen BLO hadden gevolgd maar toch maat- 
schappelijke steun nodig hadden. In enkele plaatsen ging men zich ook bezighouden met psychiatrische patiënten die, wat hun gedrag betrof, met zwakzinnigen vergelijkbaar waren. ${ }^{891} \mathrm{Zij}$ werden in de loop van de jaren dertig op veel werkinrichtingen toegelaten. In Amsterdam werd aan hen ook maatschappelijke steun verleend, wat samenhing met de organisatorische onderbrenging van de nazorg bij de afdeling geestelijke hygiëne van de GG\&GD.

Cliënten van de nazorg werden aan de hand van de bij hen vastgestelde problematiek in verschillende subgroepen ingedeeld, zoals ik uitgebreid in paragraaf 5.3 heb behandeld. Elke classificatie had z'n eigen toepassing. De classificatie naar ernst van de verstandelijke handicap was daarvan de eerste: het onderscheid tussen debielen, imbecillen en idioten werd gebruikt om te bepalen of pupillen geholpen konden worden door de nazorg. Deze stond in principe alleen open voor de debielen en de 'betere' imbecillen: al die zwakzinnigen die, al dan niet onder begeleiding, in de maatschappij konden functioneren.

De classificatie van nazorgpupillen naar arbeidsgeschiktheid, die uiteindelijk uit de driedeling 'geschikt', 'beperkt geschikt' en 'ongeschikt' bestond, kwam vooral voort uit de praktijk van het werk zoeken voor nazorgpupillen. Voor de geschikten was het betrekkelijk eenvoudig om werk te vinden en te houden, de beperkt geschikten hadden extra begeleiding nodig en de ongeschikten kwamen in principe in aanmerking voor plaatsing op een werkinrichting of, als zij ook daartoe niet in staat waren, in een gesticht.

Het onderscheid tussen 'eretische' en 'apathische' zwakzinnigen ging over de vraag, of het om drukke dan wel rustige pupillen ging. Dat was van belang voor de mate van begeleiding die nodig was om betrokken zwakzinnigen in de maatschappij te kunnen laten functioneren: eretische zwakzinnigen hadden meer begeleiding nodig dan de apathische.

Een belangrijk onderscheid dat nazorgwerkers binnen hun populatie maakten had te maken met sekse: jongens werden fundamenteel anders behandeld dan meisjes. Daarbij richtte de aandacht van de nazorgwerkers zich vooral op de jongens. Aan meisjes werd aanzienlijk minder energie besteed. Voor dit verschil in behandeling, dat door de nazorgwerkers als vanzelfsprekend werd beschouwd en op geen enkel moment ter discussie werd gesteld, zijn een drietal redenen te geven.

Allereerst was er de macht van het getal: op de scholen voor BLO zaten gemiddeld tweederde jongens en éénderde meisjes. Daardoor waren er ook in de nazorg aanzienlijk meer jongens dan meisjes en de grootste groep vroeg om de meeste aandacht.

Ten tweede speelde het feit dat alle vooroorlogse nazorgwerkers mannen waren, op Majoie in Maastricht na, een rol. Door het vrijwel geheel ontbreken van een vrouwelijk perspectief in deze jonge discipline bestond er onvermijdelijk minder oog voor de specifieke seksegebonden problematiek van de meisjes en vrouwen onder de nazorgpupillen.

Maar de derde en belangrijkste factor hierbij lag in de sociaal-culturele opvattingen in het Nederland van die dagen over de rollen die mannen en vrouwen in het leven dienden te vervullen. Aan jongens en meisjes werden verschillende maatschappelijke eisen gesteld, bij elke sekse werd verschillend gedrag als gewenst beschouwd. Dit werd als zó vanzelfsprekend ervaren, dat het niet ter discussie 
stond. Tussen de zuilen waren er op dit punt nauwelijks verschillen in opvattingen te onderscheiden.

Van jongens werd eerst en vooral verwacht dat zij in staat waren om in loondienst te werken. Dan konden zij een inkomen verwerven en zo zichzelf en een eventueel gezin onderhouden. Hun gedrag moest bij deze rol passen. Dat wilde zeggen, dat zij op gepaste wijze met anderen moesten kunnen omgaan en in groepsverband redelijk behoorden te functioneren. Binnen de nazorg werd grote nadruk gelegd op het zo hoog mogelijk opvoeren van de arbeidsgeschiktheid van jongens, zodat zij konden voldoen aan deze eisen. Enig inzicht daarin wordt verschaft door een gedicht, dat de Utrechtse nazorgwerker en hoofd der school Fr. Visser in 1942 publiceerde in het Tijdschrift voor Buitengewoon Onderwijs:

"Het hadden ferme kerels kunnen wezen,

sappig en sterk, de vaste blik gericht

op 't arbeidsleven, dat daar voor hen ligt,

gereed, zich zelf te geven zonder vrezen,

zich wetend bouwer mee te zijn van deze

grootste tijd, als enkeling verplicht

te denken aan wat aller last verlicht,

te helpen, aller wonden te genezen.

Ach, deze grote kindren denken niet,

hun scheepje drijft wat rond, ze sturen 't niet,

ze haten niet, noch treuren, noch beminnen,

ze ijvren niet, om 's levens slag te winnen,

doch weten van geen strijd, ze zijn gedwee,

verlangen niets, zijn met niets tevree. ${ }^{1892}$

Van meisjes werd niet of in veel mindere mate verwacht dat zij naar buiten traden en zich een inkomen verwierven. $\mathrm{Zij}$ moesten vooral leren om hun huishoudelijke taken te vervullen, thuis bij hun ouders of later in hun eigen gezin. Aan hun maatschappelijk functioneren werden minder hoge eisen gesteld. Binnen de nazorg lag voor hen de nadruk op het aanleren van huishoudelijke vaardigheden. Als ze al buitenshuis gingen werken, dan had daarbij van huishoudelijk werk afgeleide arbeid de voorkeur, zoals dienstbode, strijkster of wasvrouw. Werk in een fabriek werd voor zwakzinnige meisjes als volstrekt ongeschikt beschouwd, omdat hier de verleiding tot risicovol gedrag, vooral op seksueel gebied, veel te groot werd geacht.

\subsubsection{Werkwijzen van de nazorg}

De tweede deelvraag luidt: welke werkwijzen werden binnen de nazorg gehanteerd en welke ontwikkeling deed zich hier in de loop van de tijd in voor?

De hoofdlijnen van de methodiek van de nazorg waren door Pier de Boer in de jaren 1921 en 1922 ontwikkeld in het eerste anderhalf jaar dat hij als nazorgambtenaar in Amsterdam actief was. Deze had hij verder uitgewerkt in het Haarlemse nazorgrapport van1924. Inhoudelijk zou er daarna nog maar weinig aan veranderen. De indeling in maatschappelijke zorg, werkinrichting en avondverzorging als de belangrijkste werkvormen van de nazorg zou tot aan het einde van de bezetting gehandhaafd blijven. Hoe deze werkvormen moesten worden ingevuld was een 
zaak van de individuele nazorgwerkers zelf, waarbij de plaatselijke omstandigheden en mogelijkheden een belangrijke rol speelden. Nazorgwerk bleef in dit opzicht gedurende de gehele periode die dit onderzoek bestrijkt pionierswerk. Vanaf het begin van de jaren dertig, met de oprichting van de NVNBO, kwam de inhoudelijke uitwisseling tussen nazorgwerkers op structurele basis op gang.

Het centrale onderdeel van de nazorg was wat Pier de Boer in 1924 de maatschappelijke hulp had genoemd: het begeleiden van oud-leerlingen van het BLO in de maatschappij. Daarbij had het vinden en houden van werk de allerhoogste prioriteit, gevolgd door ondersteuning in de thuissituatie, die als het nodig was vervangen kon worden door pleegzorg. Het zwaartepunt van de begeleiding lag in de eerste periode na het verlaten van de school, de tijd dat oudleerlingen zich moesten aanpassen aan het leven in de maatschappij en de bescheiden rol die zij daarin te vervullen hadden. De intensiteit van de begeleiding kon na ongeveer twee jaar afnemen. Alleen oud-leerlingen met extra problematiek moesten verder begeleid worden, sommigen hun leven lang.

De ambtenaren voor de nazorg stelde zich bij de begeleiding van nazorgpupillen actief op. Pupillen, hun gezinnen en werkgevers werden gevraagd en ongevraagd bezocht, netwerken van werkgevers en hulpverleningsorganisaties werden opgebouwd en onderhouden. Daarnaast hielden nazorgwerkers vrijwel dagelijks spreekuren om zo toegankelijk mogelijk te zijn. Verder vervulden ze allerlei nevenfuncties om het hulpverleningsaanbod aan hun pupillen zo breed mogelijk te maken. Nazorgambtenaren traden op als reclasseringsambtenaar, om pupillen die met het strafrecht in aanraking waren gekomen met kracht te kunnen corrigeren. Ze waren gezinsvoogd, zodat ze in de thuissituatie van oud-leerlingen konden ingrijpen. Ze waren ambtenaar van de sociale dienst, zodat ze de uitkeringen aan hun pupillen konden beheren, en beheerden tijdens de bezetting speciale afdelingen van de arbeidsbureaus, zodat ze de arbeidsbemiddeling voor hun pupillen konden voortzetten. Ze traden op als voogd, zodat ze pupillen, als dat nodig was, aan hun ouderlijk milieu konden onttrekken. Al het handelen van de nazorgambtenaren was erop gericht om de hulpverlening aan oud-leerlingen van het BLO in één hand te houden.

De werkinrichting was een ander belangrijk onderdeelvan de nazorg. Zij was ontstaan in de jaren 1917-1920 in Dordrecht onder leiding van Wepster. Er waren aanzienlijk meer werkinrichtingen dan nazorgambtenaren, maar het aantal pupillen dat van werkinrichtingen gebruik maakte was aanzienlijk lager dan het totale aantal cliënten van de nazorgambtenaren. Landelijk gezien werkten er nooit meer dan enkele honderden personen in de werkinrichtingen, terwijl de maatschappelijke zorg al gauw enkele duizenden cliënten begeleidde.

Het oorspronkelijke doel van de werkinrichtingen was, alle oud-leerlingen van het BLO die niet tot het verrichten van arbeid in loondienst in staat waren een nuttige dagbesteding te bieden, zodat zij niet in een gesticht opgenomen hoefden te worden. Daarbij werd een onderscheid gemaakt tussen twee verschillende groepen. Aan de ene kant waren dat debiele oud-leerlingen die vanwege hun karakter- en omgangsfouten niet of zeer moeilijk in het bedrijfsleven te plaatsen waren. Aan de 
andere kant stonden de imbecillen, oud-leerlingen die de bezinkingsklassen of een speciale imbecillenschool hadden gevolgd en die als gevolg van hun matige verstandelijke beperking niet in het bedrijfsleven terechtkonden. De werkinrichtingen gingen zich al snel vooral op imbecillen richten. De oud-leerlingen met gedrags- en omgangsfouten bleken door hun gedrag een té zware belasting door de onrust die zij onder de andere tewerkgestelden verspreidden. ${ }^{893}$ Uiteindelijk zouden alleen rustige oud-leerlingen tot de werkinrichtingen worden toegelaten.

Op elke werkinrichting was een werkmeester (voor jongens) of een leidster (voor meisjes) aangesteld. Zij verdeelden het werk onder de pupillen, begeleidden hen en controleerden het eindresultaat. Het werk moest zo eenvoudig en repetitief mogelijk zijn, zodat ook de oud-leerlingen met een ernstiger verstandelijk gebrek het konden uitvoeren en zoveel mogelijk pupillen buiten het gestichtswezen gehouden konden worden. Daarbij vond men het belangrijk dat het werk lichamelijk inspannend was, zodat de tewerkgestelden lichamelijk moe werden. Loon - men sprak liever over zakgeld - werd zoveel mogelijk naar arbeidsprestatie uitbetaald, zodat pupillen werden gestimuleerd om zo hard mogelijk te werken. Elke werkinrichting hanteerde hiervoor een eigen systeem.

Werkinrichtingen werden door de nazorgwerkers nadrukkelijk beschouwd als verpleeginrichtingen. De tewerkgestelden werden daarom patiënten genoemd, om een duidelijk onderscheid te maken met commerciële bedrijven en de werkinrichtingen van de AVO, waar de nadruk werd gelegd op een bedrijfsmatige aanpak. Werkinrichtingen voor imbecillen waren in eerste instantie niet gericht op productie, maar op dagbesteding. Dat de geproduceerde artikelen daarbij geld opbrachten was een prettig bijverschijnsel, maar niet de hoofdzaak.

Nazorgwerkers vonden de avondverzorging een belangrijk onderdeel van de zorg voor oud-leerlingen van het BLO. Het was het meest voorkomende onderdeel van de nazorg en werd vaak vanuit het BLO georganiseerd. De oorsprong van de avondverzorging lag in het herhalingsonderwijs dat het reguliere lager onderwijs aan zijn oud-leerlingen aanbood. Aanvankelijk, aan het eind van de jaren tien en het begin van de jaren twintig, lag de nadruk op het bijspijkeren en onderhouden van de schoolse kennis, maar in de loop van de jaren twintig verschoof de nadruk van het avondonderwijs steeds meer naar gezelligheid en morele ondersteuning. Dat het voor oud-leerlingen van het BLO moeilijk was om lid te worden van gewone jeugd- en jongerenorganisaties was daarbij een belangrijke overweging. Mede daardoor was de avondverzorging ook het eerste onderdeel van de nazorg dat verzuild raakte. Elke levensbeschouwelijke groepering wilde haar eigen morele overtuigingen op haar eigen oud-leerlingen van het BLO overbrengen.

Het doel van de avondverzorging was, naast deze morele ondersteuning, ook om de vrije tijd van oud-leerlingen in de avonduren te kunnen controleren en beheersen. Men was bang voor de verlokkingen van de straat en vreesde dat deze de slechte aanleg van de oud-leerlingen, zwakzinnig als zij waren, naar boven zouden halen. De avondverzorging moest daartegen een tegenwicht zijn en een gezond milieu aanbieden, waardoor die slechte aanleg niet tot uiting zou kunnen komen. 


\subsubsection{Nazorg en het denken over zwakzinnigen.}

De derde deelvraag die ik wil beantwoorden is: hoe werd er binnen de nazorg gedacht over zwakzinnigen en zwakzinnigheid en hoe verhield zich dat tot het denken over zwakzinnigheid in het algemeen?

De nazorgwerkers waren kinderen van hun tijd. Hun denken over zwakzinnigheid was enerzijds beïnvloed door het degeneratiedenken van de eugenetici, zoals dat aan het einde van de negentiende eeuw was ontstaan, anderzijds door het optimistische geloof in de 'maakbaarheid van de samenleving' zoals die vooral in sociaalhygiënistische kringen bestond ${ }^{894}$ en waarmee de nazorg nauw verbonden was. Daarbij speelde ook het geloof in de kracht van de pedagogiek, in de mogelijkheid van opvoeding en beschaving van de lagere volksklassen een belangrijke rol. Vrijwel alle vroege nazorgwerkers waren afkomstig uit het onderwijs.

In dit dubbelzinnige universum, tussen eugenetiek en pedagogiek, besteedden de betrokkenen bij het BLO, en met hen de nazorgwerkers, veel aandacht aan de negatieve kanten van zwakzinnigheid. Daar konden ze, gezien de slechte naam die zwakzinnigen hadden, niet aan voorbij. Als ze iets ter bescherming en opvoeding van zwakzinnigen tot stand wilden brengen, moesten ze aangeven dat zij de negatieve eigenschappen van zwakzinnigen konden neutraliseren. De betrokkenen bij BLO en nazorg beschouwden zwakzinnigen door hun aanleg voor a- of antisociaal gedrag als een risico voor de samenleving, maar stelden daartegenover dat deze slechte aanleg onder goede omstandigheden niet tot uiting hoefde te komen. Door hen, eerst op school en later in de samenleving, op de juiste wijze pedagogisch te begeleiden stelden zij dat ze de risico's van zwakzinnigheid aanzienlijk konden beperken.

Het wantrouwen van BLO en nazorg ten opzichte van hun pupillen was door deze houding groot. De nadruk in onderwijs en zorg lag op controle en beheersing, om te voorkomen dat hun pupillen in contact zouden komen met de verleidingen die op hen een noodlottige uitwerking konden hebben. Het hele hulpverleningsprogramma van de nazorg was er op gericht om de sociale omstandigheden waaronder zwakzinnigen leefden zo optimaal mogelijk te maken. Uitgangspunt van de nazorg daarbij was, dat zwakzinnigen niet wezenlijk afweken van intellectueel normaal begaafde mensen, ze uitten zich alleen op een afwijkende manier. Zwakzinnigen hadden in principe recht op dezelfde kansen en mogelijkheden als normale mensen, maar moesten daarbij begeleid worden. Daarin speelde arbeid een centrale rol. Het werd gezien als belangrijkste middel om zwakzinnigen normaal in de maatschappij te laten functioneren.

Deze visie ontwikkelden nazorgwerkers in de jaren twintig, toen de eugenetiek aan de verliezende hand leek. In de loop van de jaren dertig begon de invloed van de eugenetiek in het maatschappelijk debat over zwakzinnigheid weer toe te nemen. Daarbij verhardden de verschillende standpunten. In de eugenetiek werd meer de nadruk gelegd op de erfelijke en onverbeterlijke slechte eigenschappen van zwakzinnigen, die hen ongeschikt voor verblijf in de samenleving zouden maken. De nazorgwerkers brachten daar inhoudelijk weinig tegenin. Zij waren geen mensen van het woord, maar van de praktijk. In die praktijk lieten zij zien dat het allergrootste deel van de zwakzinnigen geen enkel gevaar voor hun omgeving vormde. Zwakzinnigen konden over het algemeen redelijk tot goed in de samenle- 
ving functioneren. Aan het einde van de jaren dertig leek het er zelfs even op dat binnen de nazorg het paradigma dat tot dan toe de houding ten opzichte van zwakzinnigen had beheerst: zwakzinnigen zijn een risico voor de samenleving tenzij ze goed worden begeleid, in haar positieve spiegelbeeld zou veranderen: zwakzinnigen kunnen goed in de samenleving functioneren tenzij ze worden verwaarloosd.

De bezetting betekende een enorme terugslag voor dit positieve element in het denken over zwakzinnigen bij de nazorg. Door de enorme verslechtering van de sociale omstandigheden en de ineenstorting van het morele systeem nam onder alle betrokkenen bij nazorg en BLO de angst voor het tot uiting komen van de negatieve aspecten van zwakzinnigheid toe. De angst voor een massaal ontsporen van zwakzinnigen leidde tot initiatieven onder nazorgwerkers waarin plaats werd ingeruimd voor het isoleren van zwakzinnigen buiten de maatschappij.

\subsubsection{Nazorg en maatschappelijke ontwikkelingen}

De vierde deelvraag luidt: hoe verhield zich de ontwikkeling van de nazorg zich tot belangrijke maatschappelijke ontwikkelingen die zich tussen 1900 en 1945 voordeden? Uit de veelheid van ontwikkelingen die zich in deze periode voordeden heb ik er drie uitgekozen die mijns inziens van buitengewoon belang waren: de verzuiling, de economische crisis van de jaren dertig en de Duitse bezetting.

\section{A. De verzuiling}

Het belangrijkste maatschappelijk-culturele proces dat Nederland in de eerste helft van de twintigste eeuw kenmerkte, was de verzuiling. Het hoogtepunt hierin werd gevormd door de schoolstrijd, het streven van de confessionele partijen om het bijzonder onderwijs financieel gelijkgesteld te krijgen aan het openbaar onderwijs. De Pacificatiewet van 1921 beslechtte deze strijd in het voordeel van de confessionelen.

Het leek er aanvankelijk op, dat de nazorg zich aan het proces van verzuiling zou kunnen onttrekken. De eerste nazorgwerkers waren allemaal liberaal (Wepster, Frantsen, Van der Wouden) of sociaal-democratisch (De Boer, Schuyt, Werkhoven). Ze stamden allemaal uit het openbare BLO. De nazorginstellingen die zij opzetten waren algemeen georganiseerd en richtten zich op oud-leerlingen van alle levensbeschouwingen. Toen zij zich verenigden in de NVNBO sloten zich daarbij al snel confessionele nazorgwerkers aan. De NVNBO was lange tijd de enige landelijke organisatie van nazorgwerkers.

Toch waren er binnen de nazorg vrijwel vanaf het begin al verzuilingsprocessen te onderscheiden. Dat is het beste af te lezen aan de ontwikkeling van de avondverzorging. Deze werd al vroeg per levensbeschouwing georganiseerd. Nazorgwerkers speelden er slechts een marginale rol in. Ze maakten de avondverzorging fysiek mogelijk: ze organiseerden de ruimte, zorgden voor subsidiëring en reikten ideeën aan voor de invulling ervan, maar waren niet bij de uitvoering ervan betrokken. Vooral vanuit confessionele hoek werd daar zeer veel waarde aan gehecht, omdat zij de avondverzorging als een middel zagen om hun eigen geloofsovertuiging, waarden en normen over te brengen op hun eigen oudleerlingen. Ze wensten daarbij absoluut geen inmenging van andersdenkenden.

Vanaf het einde van de jaren twintig ontstonden de eerste verzuilde nazorgorganisaties. De eerste daarvan was de katholieke nazorg in Breda. In 1934 
gorganisaties. De eerste daarvan was de katholieke nazorg in Breda. In 1934 werd de eerste protestants-christelijke nazorgorganisatie opgericht in Dordrecht, die naast de algemene nazorg van Wepster stond en zich alleen richtte op de oudleerlingen van de protestants-christelijke school voor BLO,

Een deel van de confessionelen sloot zich aan bij de NVNBO. Ze vonden de omvang van de nazorg in Nederland nog té klein om eigen landelijke organisaties te rechtvaardigen, maar het was nadrukkelijk wél de bedoeling dat die er zouden komen. De katholieken waren er het vroegste bij. Zij maakten vanaf het midden van de jaren dertig al plannen om tot een landelijke R.K. nazorgorganisatie te komen. Vóór het einde van de bezetting zou het daar niet van komen.

\section{B. Economische crisis}

Van groot belang voor de ontwikkeling van de nazorg was de economische conjunctuur. Meest opvallend verschijnsel op dit gebied was de diepe en langdurige economische crisis van de jaren dertig. De nazorg werd hierdoor op verschillende en soms tegengestelde manieren beïnvloed.

Allereerst was er de financiële invalshoek. Gemeenten, die voor de subsidiëring van de nazorg verantwoordelijk waren, hadden zeker in periodes van economische tegenslag grote belangstelling voor maatregelen die hun uitgaven konden beperken. Tijdens de crisis van de jaren dertig hadden de nazorgwerkers hier voordeel van. Ze wisten hun werk bij de gemeentelijke overheden te presenteren als kostenbesparend. Door middel van nazorg zouden de kosten van gestichtsverpleging beperkt kunnen worden. Hierdoor bleef de nazorg gedurende de gehele crisisperiode een - weliswaar bescheiden - groei vertonen. Her en der in het land werd er dan wel op onderdelen van de nazorg bezuinigd, maar de omvang hiervan bleef zeer beperkt.

De crisis van de jaren dertig betekende voor de nazorgwerkers een aanzienlijke werkverzwaring. Vooral de plaatsing in loondienst van oud-leerlingen van het BLO werd bemoeilijkt. De werkloosheid nam in deze periode aanzienlijk toe waardoor het voor iedereen moeilijker werd om werk te vinden. Een probleem voor oud-leerlingen van het BLO was, dat werkgevers bij het selecteren van personeel eerder geneigd waren mensen zónder extra problematiek aan te nemen, die bovendien in ruime mate voorhanden waren. Daardoor werd het voor oud-leerlingen extra moeilijk om werk te vinden. Het enige voordeel dat zij hadden was dat aan hen, vanwege hun verminderde arbeidsprestatie, minder loon betaald hoefde te worden.

Door de stagnerende of dalende koopkracht van de bevolking in de jaren dertig kwam ook de afzet van producten van de werkinrichtingen in de verdrukking. Dat speelde vooral een rol als de producten in het reguliere commerciële circuit afgezet moesten worden. De concurrentie was moordend. Als een werkinrichting haar producten rechtstreeks aan particulieren afzette, was dat veel minder een probleem vanwege de speciale band tussen koper en verkoper, die door een vaak jarenlange relatie tot stand was gekomen. Werkinrichtingen hechtten daarom, zeker in de jaren dertig, zeer aan deze speciale vorm van verkoop, ook al kostte deze veel tijd en energie.

Wat in de jaren dertig het werk van de nazorg ook moeilijker maakte, was 
de concurrentie van aanverwante hulpvormen. Deze hadden net als de nazorg te maken met een overheid die zeer kritisch was op haar uitgaven en moesten zich daarom tot het uiterste inspannen om te kunnen voortbestaan. Dat betekende dat soms pogingen werden ondernomen om (delen van) het werkterrein van de nazorg over te nemen, zoals dat bijvoorbeeld bij de arbeidsbemiddeling voor onvolwaardigen het geval was. Het kostte, zowel op plaatselijk als landelijk niveau, veel inzet van de nazorgwerkers om dit tegen te gaan.

\section{De bezetting}

De houding tegenover de bezetter in kringen van BLO en nazorg is enigszins naïef te noemen. De nadruk lag op het voortzetten van het werk, hoe moeilijk de omstandigheden ook mochten zijn en op het beschermen van de nazorgpupillen tegen de verslechterende sociale omstandigheden. Er lijkt sprake te zijn geweest van een soort bewustzijnsvernauwing. Aan de ene kant probeerde men pupillen tegen maatregelen van de bezetter te beschermen, bijvoorbeeld als het ging over tewerkstelling in Duitsland. Aan de andere kant nam men, overigens geheel te goeder trouw, maatregelen die het de bezetter makkelijker maakten om maatregelen tegen zwakzinnigen te nemen. Nazorgwerkers lijken niet te hebben nagedacht over de gevaren, die de nationaal-socialistische ideologie voor hun pupillen konden inhouden.

Die houding blijkt vooral uit het opzetten van de landelijke registratie van oud-leerlingen van het BLO bij de Inspectie in 1941. Het was een oude wens van de nazorg om tot een dergelijk landelijk archief te komen en het lijkt erop, dat de nazorgwerkers dachten van de bezetting gebruik te kunnen maken om eindelijk een dergelijk archief op te zetten. Daarbij realiseerden zij zich niet dat daarmee de bezetter in de kaart kon worden gespeeld. Dat bleek in 1944, toen de bezetter inzage in het archief wenste. De vernietiging van het archief, amper drie jaar nadat het werd opgezet, en het verdere verloop van de oorlog hebben toen voorkomen dat er in Nederland maatregelen tegen zwakzinnigen werden genomen.

De argeloosheid van de nazorg blijkt ook uit het opzetten van een werkkamp voor debielen aan het begin van 1944. Het idee, dat een concentratie van problematische zwakzinnigen wel eens gevaarlijk voor de geïnterneerden zou kunnen zijn, werd door een enkeling onderkend, maar door de meesten afgewezen. Nazorgwerkers waren, overigens net zoals veel betrokkenen bij de jeugdzorg, al tijdens de bezetting bezig om zich voor te bereiden op de toestand van hun pupillen ná de bezetting. Daardoor hadden ze nog maar weinig oog voor die bezetting zelf, die echter nog volop gaande was en naarmate ze langer voortduurde steeds grimmiger van karakter werd.

\subsubsection{Nazorg en BLO}

De vijfde deelvraag luidt: wat was de bijzondere relatie die de nazorg met het BLO had en ontwikkelde deze zich tussen 1900 en 1945 ?

De nazorg ontstond vanaf 1905 als een aanvulling op het BLO en was er nauw mee verbonden. Dat kwam omdat het vooral de onderwijzers waren die de nazorg voor hun oud-leerlingen vorm en inhoud gaven en hen begeleidden bij de moeilijke overgang van school naar maatschappij. Met de professionalisering van de nazorg begon een zéér langzaam proces van uit-elkaar-groeien, dat tientallen 
jaren zou gaan duren.

Dit proces duurde zo lang omdat de professionele nazorg in de periode die door dit onderzoek bestreken wordt slechts een klein gedeelte van de populatie oud-leerlingen van het BLO bediende. Nazorg door de onderwijzers van het BLO bleef regel, de professionele nazorg was uitzondering. Daarbij kwam dat de meeste vroege nazorgwerkers uit het BLO afkomstig waren of, als zij hun functie in deeltijd uitoefenden (Wepster in Dordrecht, Frantsen in Vlaardingen), er nog steeds werkzaam waren. De meeste nazorgwerkers waren lid van een landelijke BLOorganisatie en namen actief deel aan de inhoudelijke discussies over BLO en nazorg die vooral in de jaren twintig werden gevoerd.

Toch was er zo nu en dan sprake van wrijving tussen BLO en nazorg. Daarbij ging het vooral over de vraag, hoe lang de schoolse invloed zich diende uit te strekken. De nazorg vond dat het schoolse verband diende te eindigen op het moment dat de leerling het BLO verliet. Betrokkenen bij het BLO hadden zo nu en dan de neiging om de schoolse invloed te willen verlengen. Voorbeelden hiervan waren de Rotterdamse ambachtscursussen, het conflict tussen het Amsterdamse BLO en de GG\&GD in 1924 over de invulling van de werkinrichting voor imbecillen en de discussie aan het einde van de jaren twintig binnen O\&A over de vraag, hoe onderwijs en nazorg beter op elkaar konden aansluiten. De nazorg vond, dat de school haar leerlingen ooit zou moeten loslaten, hoe pijnlijk dat ook zou zijn. Het beste was het om dat direct bij het overschrijden van de leerplichtige leeftijd te doen en het niet uit te stellen. Het was dan voor de oud-leerling duidelijk dat de school voorbij was en de nazorg begon, die haar nieuwe pupil zou begeleiden bij de eerste moeizame stappen in de vrije maatschappij.

\subsubsection{Nazorg en aanverwante hulpvormen}

De zesde deelvraag luidt: wat was de verhouding van de nazorg tot andere hulpvormen die, geheel of gedeeltelijk, op hetzelfde werkterrein actief waren?

In haar dagelijkse praktijk had de nazorg het meeste te maken met de psychiatrie en dan vooral de sociale psychiatrie, die vanuit de gemeentelijke gezondheidszorg was ontstaan. De sociale psychiatrie beschouwde zwakzinnigen als een onderdeel van haar eigen werkterrein, ze werden gezien als een onderdeel van de grote groep geestelijke en sociale afwijkelingen, die de voornaamste doelgroep van de sociale psychiatrie vormden. In de loop der jaren wăren er vanuit de psychiatrie verschillende initiatieven genomen richting deze doelgroep. In 1910 was de Centrale Vereniging ter Behartiging van de Belangen van Zwakzinnigen opgericht, de Vereniging Maatschappelijk Werk bij Zenuwlijders en Krankzinnigheid was in 1917 gesticht en de Centrale Vereniging ter Behartiging van de Belangen van Zenuw- en Zielszieken in 1924. In hetzelfde jaar ging ook de Nederlandsche Vereeniging ter bevordering der Geestelijke Volksgezondheid (NVGV) van start.

Door de belangstelling voor lichtzwakzinnigen als doelgroep van haar zorg, stonden er ook psychiaters aan de wieg van de nazorg: de vooraanstaande hoogleraar neurologie en psychiatrie, K.H. Bouman, drijvende kracht achter de NVGV ${ }^{895}$ was een van de auteurs van het Amsterdamse nazorgrapport uit 1917, dat de professionalisering van de zorg voor oud-leerlingen van het BLO inluidde. De Amsterdamse nazorg die naar aanleiding van dit rapport ontstond werd in 1923 
ondergebracht bij de afdeling Geestes- en Zenuwzieken van de Amsterdamse Geneeskundige Dienst, die onder leiding stond van één van de eerste sociale psychiaters, F.S. Meijers, die een centrale rol speelde in de Centrale Vereniging ter Behartiging van de Belangen van Zenuw- en Zielszieken.

De nauwe verbondenheid tussen nazorg en sociale psychiatrie leidde met enige regelmaat tot schermutselingen. Daarbij ging het steevast over de vraag, waar het primaat over de zorg voor oud-leerlingen van het BLO lag. Omdat psychiaters de nazorg beschouwden als een onderdeel van hun eigen werkveld, zagen ze nazorgwerkers vaak als ondergeschikten. Nazorgwerkers stelden, dat het omgaan met lichtzwakzinnigen een eigen deskundigheid vereiste, los van de psychiatrie. Zij beschouwden zich daarom als gelijken van de psychiaters. Dat leidde vaak tot conflicten, die des te heftiger waren naarmate de verhouding tussen nazorg en psychiatrie minder duidelijk was geregeld.

Deze moeizame verhouding wilde niet zeggen dat nazorgwerkers samenwerking met de psychiatrie categorisch afwezen. Ze vonden dat psychiaters wel degelijk een rol te vervullen hadden, bijvoorbeeld bij de keuring van oud-leerlingen voor toelating tot de werkinrichting en bij de beoordeling of er naast zwakzinnigheid ook nog sprake was van psychiatrische problematiek.

De relatie tussen psychiatrie en nazorg was zeker geen eenrichtingsverkeer. Het is redelijk te veronderstellen dat de sociale psychiatrie in Amsterdam veel van de methodiek van de nazorg heeft overgenomen. In de jaren dertig was de maatschappelijke zorg voor geestelijk onvolwaardigen die niet als zwakzinnig waren geclassificeerd voor een belangrijk deel aan de nazorg van Pier de Boer opgedragen. Die behandelde deze cliënten niet wezenlijk anders dan de oud-leerlingen van het BLO.

De relatie tussen nazorg en residentiële zwakzinnigenzorg was aanzienlijk minder intensief dan met de psychiatrie, ook al zouden de werkvelden in theorie veel meer met elkaar te maken moeten hebben. Aan het einde van de jaren twintig ging men wat vaker met elkaar in discussie over de plaats van lichtzwakzinnigen in de maatschappij, een discussie die aan het begin van de jaren dertig weer verstomde. Deze discussie speelde tussen nazorgwerkers en vertegenwoordigers van de internaten, kleine residentiële instellingen waar vooral kinderen van welgestelde ouders woonden. Omdat nazorgwerkers vooral te maken hadden met kinderen uit de lagere sociale klassen, waren nazorg en internaten geen directe concurrenten van elkaar. Hierdoor had een diepgaande discussie voor beide partijen weinig betekenis.

Veel meer hadden nazorgwerkers te maken met de grote zwakzinnigengestichten, waar de zorg op een veel grotere schaal plaatsvond dan in de internaten. Zwakzinnigen die op kosten van de gemeenten werden verpleegd werden hier geplaatst. Voor de gestichten betekende de nazorg wél concurrentie, omdat er door de nazorg minder kinderen bij hen geplaatst werden. Tot inhoudelijke confrontaties tussen nazorg en gestichten kwam het niet. Dat kan ermee te maken hebben gehad dat nazorgwerkers ook optraden als plaatsers van hun pupillen in gestichten, als de begeleiding in de maatschappij uiteindelijk niet voldoende was gebleken. Daardoor hadden gestichten belang bij een goede relatie met de nazorgwerkers. 
Het meest conflictrijk was de relatie tussen de nazorg en organisaties voor arbeidsbemiddeling, de arbeidsbeurzen en de arbeidsvoorziening voor onvolwaardigen in de vorm van de $A V O$.

Met de arbeidsbeurzen bestonden problemen, omdat zij probeerden een deel van het nazorgwerk, de beroepskeuze en de arbeidsbemiddeling, over te nemen. Vanuit de arbeidsbeurzen werd geredeneerd dat zij op dit gebied dé specialisten waren en dat deze taken daarom bij hen thuishoorden. Vanuit de nazorg werd gesteld dat de zorg voor oud-leerlingen van het BLO veel meer inhield dan alleen beroepskeuze en bemiddeling naar een baan. Het werk begon pas écht als er eenmaal een baantje gevonden was, de begeleiding moest dan bijzonder intensief zijn. De nazorgwerkers stelden dat het geheel van deze zorg het beste in één hand kon blijven.

De verschillende gemeentelijke overheden volgden de redenering van de nazorg. De arbeidsbeurzen kregen op dit gebied amper een poot aan de grond. Daarin leek verandering te komen tijdens de bezetting, toen de gehele arbeidsvoorziening werd gecentraliseerd en de arbeidsbureaus het monopolie op arbeidsbemiddeling kregen. De rol van de nazorg op dit gebied leek toen te zijn uitgespeeld. Op departementaal niveau werd echter besloten, dat de nazorgwerkers de arbeidsbemiddeling voor hun pupillen mochten voortzetten. Daartoe werden zij formeel aangesteld bij de arbeidsbureaus met als opdracht de arbeidsbemiddeling voor alle lichtzwakzinnigen in het district waarin zij werkzaam waren ter hand te nemen. Door deze ingreep kon het nazorgwerk intact blijven.

De nazorg had een ingewikkelde en moeizame relatie met AVO, Arbeid Voor Onvolwaardigen, een organisatie die vanuit kringen van de arbeidsbemiddeling was opgericht om de arbeidsvoorziening voor mensen met een gebrek beter te organiseren. Het belangrijkste probleempunt was, dat de AVO de werkinrichtingen voor oud-leerlingen van het BLO tot haar werkveld rekende, terwijl de nazorgwerkers zich op het standpunt stelden dat de AVO daar niets mee te maken had. Dit verschil in inzicht leidde in de loop van de jaren dertig en veertig tot een aantal conflicten tussen AVO en NVNBO. Tijdens de bezetting werd de relatie met de AVO zelfs buitengewoon grimmig en probeerde men actief elkaars activiteiten te dwarsbomen.

Toch werkten NVNBO en AVO ook samen als de omstandigheden dat noodzakelijk makten. Dat ging het beste als het om de oplossing van concrete problemen ging. Als de samenwerking een meer vastere vorm moest krijgen, ging het mis, omdat de AVO dan, volgens de nazorgwerkers, steevast probeerde de leiding over de nazorg te verkrijgen.

De voortdurende wrijvingen met de AVO hadden ook een positieve kant. Het droeg bij aan de ontwikkeling van een eigen identiteit van de nazorg. Ze leidden er toe dat de nazorgwerkers, verenigd in de NVNBO, zich meer op de landelijke overheid gingen richten om tegenwicht te bieden aan de AVO, die op landelijk niveau een uitstekend netwerk had. De nazorgwerkers waren vanouds vooral op de gemeenten gericht en hadden daardoor op landelijk niveau amper contacten. Door de strubbelingen met de AVO tijdens de bezetting en de inzet van de Haagse nazorgwerker Van Dijk kwam daar verandering in en kon de NVNBO zich op landelijk bestuurlijk niveau beter profileren. 


\subsection{Conclusie: maatschappelijke integratie van oud-leerlingen van het BLO}

De paradox van de nazorg is, dat zij voortkwam uit een maatregel die bedoeld was om kinderen met een licht verstandelijk gebrek uit het gewone onderwijs te verwijderen en de opdracht kreeg om deze kinderen, na het voltooien van een speciale schoolopleiding, een plek te laten verwerven in de maatschappij.

Deze paradox is minder groot dan zij in eerste instantie lijkt. De scholen voor BLO bevonden zich in de samenleving. Kinderen die dit onderwijs volgden konden bij hun ouders blijven wonen. Het ging niet om volledige segregatie, waarbij kinderen geheel uit de samenleving verwijderd werden, maar om een gedeeltelijke segregatie waarbij alleen de schoolopleiding betrokken was. In termen van een civilisatieproces is de uitstoting van 'abnormale' leerlingen uit het reguliere onderwijs te beschouwen als een stap in het proces van verwijdering van afwijkenden uit de maatschappij. Maar tegelijkertijd was het BLO ook een manier om kinderen niet geheel uit de maatschappij te verwijderen. $\mathrm{Zij}$ was er immers op gericht, kinderen al dan niet onder begeleiding binnen de samenleving te houden.

Direct vanaf de start van het BLO aan het einde van de negentiende eeuw waren onderwijzers en onderwijzeressen bezorgd over wat er met hun leerlingen zou gebeuren als zij eenmaal de school hadden verlaten. Zij zetten zich in om ervoor te zorgen dat hun oud-leerlingen goed terecht kwamen. Maar ondanks de eerste positieve berichten over deze groep werd al snel duidelijk dat, als hun aantal toenam, de hulp van onderwijskrachten tekort schoot. Men was bang dat oudleerlingen van het BLO uiteindelijk aan de zelfkant van de samenleving terecht zouden komen, waar ze zich niet of met grote moeite zouden kunnen handhaven. Een dergelijke situatie werd als ongewenst beschouwd, zowel voor het betrokken individu, dat een weinig vreugdevol leven te wachten stond, als voor de samenleving als geheel, die er overlast van zou ondervinden.

Deze angst werd gevoed door een samenstel van opvattingen over zwakzinnigen, die W.E. Fernald, hoofd van een school voor zwakzinnigen en bekend publicist uit de Verenigde Staten, in 1924 de Legend of the Feebleminded ${ }^{896}$ had genoemd: het idee, dat lichte zwakzinnigheid voorbestemde tot immoraliteit, misdaad, prostitutie en pauperisme, in de loop der generaties zou verergeren en dat lichtzwakzinnigen zich sneller zouden voortplanten dan normaalbegafdgande stoelde op een hele reeks onderzoeken naar specifieke families waarin veel criminaliteit, pauperisme en zwakzinnigheid zou voorkomen. De eerste daarvan was The Jukes van Dugdale, dat in 1916 een vervolgstudie kreeg van Estabrook. Het bekendst was (en is) echter de studie van Goddard naar de familie Kallikak uit $1914{ }^{897}$ Ook in Nederland leek een onderzoek van Bartels uit 1916 naar zwakzinnigen in justitiële inrichtingen in Nederland deze legende te bevestigen. Vooral Goddard werd in de navolgende decennia aangehaald in de vakliteratuur, waarbij onderzoek dat een meer positief beeld gaf van lichtzwakzinnigen nadrukkelijk werd genegeerd ${ }^{898}$ Het leidde ertoe, dat oud-leerlingen van het BLO met het grootst mogelijke wantrouwen werden bejegend. Ze werden op zijn minst als een risico voor de samenleving gezien en door velen als een onbeheersbaar gevaar beschouwd. Er gingen stemmen op om hen uit de samenleving te isole- 
ren en hun voortplanting onmogelijk te maken. Aan het begin van de twintigste eeuw stond men daarom open voor allerlei manieren om de zorg aan de oudleerlingen van het BLO vorm te geven, als daardoor maar de maatschappij tegen zwakzinnigen beschermd zou worden.

De eerste pogingen hiertoe werden in Den Haag ondernomen met het filantropische model, dat zo succesvol was geweest in de negentiende eeuw. Het was daarbij de bedoeling, dat goedwillende burgers op basis van vrijwilligheid oud-leerlingen zouden helpen bij het zoeken van werk en het ondersteunen bij het zetten van de eerste stappen in de maatschappij. Deze poging mislukte, omdat er maar amper mensen bereid gevonden konden worden dit werk te doen en zij daarnaast over onvoldoende deskundigheid beschikten om de oud-leerlingen goed te kunnen helpen.

De tweede poging, in Rotterdam, bestond uit het verlengen van de schoolse periode in de vorm van een aangepaste vakopleiding. De bedoeling was om de beste BLO-leerlingen zóveel extra kennis en vaardigheden bij te brengen, dat ze als vakarbeider aan de slag zouden kunnen gaan. Ook dit experiment mislukte. Het probleem van de overstap van school naar maatschappij werd door de vakopleiding niet opgelost, alleen maar enkele jaren vooruit geschoven. Na enkele jaren bleek bovendien dat de meeste leerlingen geen werk vonden in het vak waarvoor ze waren opgeleid. Tenslotte bleven bij de vakopleiding de zwakste oud-leerlingen, die de meeste behoefte hadden aan hulp in de maatschappij, buiten beschouwing.

Het eerste experiment dat wél lukte had een bescheiden omvang en was gericht op het oplossen van een praktisch probleem. Het ging er om enkele oudleerlingen van de Dordtse school voor BLO, voor wie geen werk gevonden kon worden, een nuttige dagbesteding te bezorgen, zodat ze niet naar een gesticht hoefden te worden overgebracht. Zij kregen de mogelijkheid in een beschutte omgeving aangepaste arbeid te verrichten. De gemeente bleek in de werkinrichting geïnteresseerd, omdat de kosten van gestichtsverpleging hoog waren en verleende subsidie. Werkinrichtingen richtten zich op de zwakste oud-leerlingen van het BLO, die niet in staat waren om arbeid in loondienst te verrichten. Het zou tot een wijdverspreid onderdeel van de nazorg uitgroeien.

Het tweede geslaagde experiment met vormen van nazorg bestond uit een proef met professionele hulpverlening aan oud-leerlingen van de Amsterdamse scholen voor BLO. Dat was juist in een periode dat in Nederland de professionalisering van de hupverlening van de grond kwam. Het filantropische model bleek niet meer te voldoen. Om verantwoord hulp te kunnen verlenen waren veel meer kennis en vaardigheden nodig dan waarover goedwillende vrijwilligers ooit zouden kunnen beschikken. Hulpverlening werd langzaamaan een vak.

In de psychiatrie werden in het eerste kwart van de twintigste eeuw verschillende proeven gedaan met professionele hulp aan oud-gestichtsbewoners in de samenleving en gemeenten waren bereid hieraan geld uit te geven, omdat ze hierdoor de kosten van gestichtsverzorging konden beperken. Juist toen dit proces op gang begon te komen, werd de eerste professionele nazorgambtenaar in Amsterdam aangesteld. Hij kreeg twee jaar de tijd om te laten zien dat deze vorm van hulpverlening bestaansrecht had. Hij toonde in die periode aan dat een professionele kracht de deskundigheid en het gezag kon opbouwen die nodig waren om de zorg voor oud-leerlingen van het BLO verantwoord en met een voldoende 
oud-leerlingen van het BLO verantwoord en met een voldoende hoog slagingspercentage uit te voeren. De professionalisering van de nazorg was begonnen en in de loop van de tijd werden in meerdere gemeenten nazorgambtenaren aangesteld.

Over het algemeen werd er tot nazorg overgegaan als de scholen voor $\mathrm{BLO}$ in een gemeente grotere aantallen oud-leerlingen gingen afleveren. Het onderwijzend personeel kon hen dan niet meer voldoende helpen. Hoe de nazorg concreet werd ingevuld, verschilde van gemeente tot gemeente. Provinciale of landelijke sturing ontbrak geheel. Nazorg bestond als gemeentelijke dienst en kon bij de geestelijke gezondheidszorg of bij de afdeling onderwijs zijn ondergebracht. Nazorg werd soms georganiseerd als een particuliere vereniging, die alle BLOscholen van een gemeente bediende, of zich juist richtte op de scholen van één specifieke levensbeschouwelijke richting. Nazorg kon onderdeel zijn van de ondersteuningsorganisatie van een BLO-school en zich ook met de leerlingen ervan bezighouden, of zich alleen op de oud-leerlingen richten. Nazorg kon alleen uit een werkinrichting bestaan, alleen maatschappelijke zorg bieden of beiden combineren.

Juist omdát er geen sturing van bovenaf was, kon er naar hartelust geëxperimenteerd worden met de invulling van deze zorg. Een keerzijde hiervan was, dat lang niet overal nazorg tot stand kwam. Het hing af van het inzicht dat individuele gemeentebesturen over dit onderwerp hadden. Het ontbreken van centrale sturing betekende, dat de eerste nazorgwerkers pioniers waren die alleen werkten. Contacten met collega-nazorgwerkers waren sporadisch en meestal in het kader van aanverwante vakgebieden zoals het BLO, de sociale psychiatrie en de sociale werkvoorziening. Men sprak elkaar op verschillende congressen, publiceerde in de vakbladen voor BLO en bezocht elkaar zo nu en dan, maar een vaste structuur hiervoor ontbrak. Daarin kwam verandering in 1931, toen de NVNBO werd opgericht. Deze organisatie zou uitgroeien tot hét belangenbehartigings- en overlegorgaan van de nazorg in de jaren dertig en veertig. Door deze organisatie kon de nazorg ook op landelijk niveau haar stem laten horen. Dat was belangrijk, omdat in de loop van de jaren dertig de belangstelling van de landelijke overheid voor de nazorg, en de onvolwaardigenzorg in het algemeen, toenam. De nazorg kreeg steeds meer met de landelijke overheid te maken, onder andere op het gebied van de grondstoffenvoorziening van de werkinrichting en de ordening van de economie tijdens de Tweede Wereldoorlog.

In de jaren dertig stokte de inhoudelijke ontwikkeling van de nazorg, die in de jaren twintig haar hoogtepunt had bereikt. Dat had vooral te maken met de zware economische crisis waarin Nederland terechtgekomen was. Het nazorgwerk werd hierdoor aanzienlijk verzwaard. Bovendien groeide het aantal pupillen in deze periode fors, terwijl daar geen extra financiële middelen tegenover stonden. Hier en daar werd er zelfs op de nazorg bezuinigd. Door deze factoren samen was er amper tijd om de nazorg te overdenken, laat staan inhoudelijk te vernieuwen. In deze periode ontstonden hooguit aanvullingen op het bestaande nazorgprogramma, die te maken hadden met nieuwe problemen die zich in de nazorgpraktijk voordeden.

Tijdens de bezetting was de inzet van de nazorgwerkers er vooral op gericht het nazorgwerk in stand te houden. Later in de bezetting, toen de omstandigheden in Nederland verslechterden en de grens tussen goed en fout gedrag vervaagde, zetten nazorgwerkers in op het zoveel mogelijk in het juiste spoor houden 
van de oud-leerlingen van het BLO. Ze vreesden in deze periode voor het volledig afglijden van hun pupillen in criminaliteit en a- of antisociaal gedrag. De angst voor de slechte aanleg van zwakzinnigen stak de kop weer op. Dit verklaart de op het eerste gezicht paradoxale inzet van nazorgwerkers voor het oprichten van residentiële voorzieningen voor hun pupillen. Deze waren er op gericht de omstandigheden van oud-leerlingen die onder de slechtste sociale omstandigheden leefden te verbeteren en onder controle te houden. De belangrijkste prestatie van de nazorgwerkers in deze periode was dat zij erin slaagden het nazorgapparaat zoals dat in mei 1940 bestond redelijk ongeschonden door de bezetting te loodsen, zodat ná de bevrijding in 1945 daarop kon worden voortgebouwd.

In de toelichting op de hoofdvraag (paragraaf 1.2) ben ik al ingegaan op de wijze waarop ik het begrip integratie interpreteer. Het gaat daarbij vooral om het handhaven van lichtzwakzinnigen in hun eigen sociale omgeving, het behoud van een gegeven situatie in plaats van het bewerkstelligen van een nieuwe. Er werden wel lichtzwakzinnigen vanuit internaten en gestichten teruggeplaatst in de maatschappij, maar hun aantal stond niet in verhouding tot de oud-leerlingen van de scholen voor BLO die zich door de hulp van de nazorg in de maatschappij konden handhaven.

Als integratie op deze manier geïnterpreteerd wordt, dan zijn de nazorgwerkers daar grotendeels in geslaagd. Een groot deel van de pupillen van de nazorg kon zich na het verlaten van de school al dan niet onder begeleiding handhaven in de maatschappij. Een aanzienlijk deel van hen, ongeveer éénderde, kon zelfs helemaal zonder begeleiding toe. Dat betekende dat zij, in de definitie die Van Voorthuijsen in 1926 had gegeven, ${ }^{899}$ niet meer als zwakzinnig te beschouwen waren. Voor oud-leerlingen van het BLO die meer moeite hadden met het opbouwen van een zelfstandig bestaan kwamen er speciale voorzieningen om het verblijf in hun eigen sociale omgeving te kunnen voortzetten. Slechts een klein gedeelte van de oud-leerlingen, de allermoeilijkste gevallen, kwam uiteindelijk in een residentiële instelling terecht.

Nazorgwerkers hebben ook in ander opzicht bijgedragen aan de integratie van lichtzwakzinnigen in de maatschappij. Zij droegen er door hun activiteiten toe bij, dat het beeld dat er van zwakzinnigen bestond in de maatschappij ten positieve werd bijgesteld. Zij wisten de maatschappelijke kaders, waarvan zij zelf deel uitmaakten, te doen verschuiven. Sleutel daarbij was het belang, dat nazorgwerkers hechtten aan verrichten van arbeid door hun pupillen. Arbeid had in de Nederlandse en de gehele westerse context van de eerste helft van de twintigste eeuw een bijzondere betekenis. Het had niet alleen economische waarde, diende niet alleen om zich een inkomen te verwerven, maar had ook een belangrijke intrinsieke waarde. Alleen door het verrichten van arbeid kon een mens zichzelf verwezenlijken, al dan niet in relatie tot een hoger wezen. Deze opvatting werd door alle zuilen in Nederland gedeeld, door zowel confessionelen, liberalen als sociaal-democraten. Nazorgwerkers deelden deze opvattingen en stelden zich op het standpunt dat arbeid niet aan lichtzwakzinnigen onthouden mocht worden. Arbeid had in hun optiek een buitengewoon gunstige invloed op lichtzwakzinnigen, omdat het zou voorkomen dat de slechte aanleg die zij hadden zich zou ontplooien. Arbeid gaf 
structuur, rust en afleiding en vergrootte het zelfvertrouwen.

Door in de praktijk aan te tonen dat zwakzinnigen in staat waren om arbeid te verrichten lieten nazorgwerkers zien dat zwakzinnigen wel degelijk konden bijdragen aan het welzijn van de samenleving als geheel en dus niet allemaal waren voorbestemd om overlast te veroorzaken. Nazorgwerkers lieten zien dat zwakzinnigen kennelijk niet zo erg veel afweken van intellectueel normaal begaafde mensen en dat zij, als er voldoende aandacht aan hen werd besteed, zelfs konden bijdragen aan het welzijn van de samenleving als geheel. In deze zin hebben nazorgwerkers in belangrijke mate bijgedragen aan een begin van verandering in houding ten opzichte van zwakzinnigen die zich in de tweede helft van de twintigste eeuw verder zou voortzetten. Aan het begin van de éénentwintigste eeuw was er van de negatieve connotaties die honderd jaar eerder, aan het begin van de twintigste eeuw, nog aan het begrip zwakzinnigheid waren verbonden, niet veel meer over.

De nazorg, die zich speciaal richtte op mensen met een lichte verstandelijke handicap, is te beschouwen als een uitwerking en een concreet voorbeeld van de beschavingsgedachte uit de negentiende eeuw die zich voortzette in de twintigste. Het beschaven werd in de twintigste eeuw niet langer overgelaten aan goedwillende vrijwilligers, maar opgedragen aan professionele krachten, die zich met ongelooflijk veel kracht en energie inzetten voor 'hun' pupillen en zich in de loop van de twintigste eeuw ontwikkelden tot een eigen discipline, de sociale pedagogiek.

In deze ontwikkeling speelde het spanningsveld tussen het positivisme van de maakbaarheid van de samenleving dat het sociaalhygiënisme kenmerkte en het negativisme van de eugenetiek en de idee van het onveranderbare karakter van erfelijke eigenschappen een belangrijke rol. Binnen dit spanningsveld speelde de discussie over de invloed van intelligentie op menselijk gedrag een belangrijke rol, vooral omdat intelligentie werd gezien als het belangrijkste onderscheidende kenmerk tussen mens en dier. De vraag, hoe er met zwakzinnigen moest worden omgegaan kwam daardoor centraal te staan in het debat tussen eugenisten en sociaalhygiënisten. In de jaren tien en twintig leken daarbij de sociaalhygiënisten de overhand te hebben, in de jaren dertig en veertig werd het negativisme van de eugenetiek krachtiger en leek de rol van de erfelijkheid weer een hoofdrol te gaan spelen.

Binnen dit spanningsveld kozen de betrokkenen bij de nazorg voor een manier van begeleiding die kan worden samengevat als 'leiding geven': door het leven van lichtzwakzinnige oud-leerlingen van het BLO zoveel mogelijk te controleren en beheersen probeerden ze de gevaren die er, vanwege hun aanleg, van hen zouden uitgaan, zoveel mogelijk te neutraliseren. Op deze manier combineerden zij het positivisme van het sociaal-hygiënisme met het wantrouwen van de eugenetiek in hun omgang met lichtzwakzinnigen.

Het was een aanpak die bleek te werken. De nazorg heeft in de praktijk laten zien dat het mogelijk was om lichtzwakzinnigen te handhaven in hun eigen sociale omgeving, zelfs in tijden van grote maatschappelijk onrust. Hierdoor heeft de nazorg in belangrijke mate bijgedragen aan de acceptatie van het verblijf van lichtzwakzinnigen in de maatschappij. 


\section{Noten}

\section{Gebruikte afkortingen in de noten}

AGO Arbeid voor Geestelijk Onvolwaardigen, de organisatie die in Amsterdam werkinrichtingen voor zwakzinnigen exploiteerde.

AMW: Tijdschrift voor Armwezen, Maatschappelijk Werk en Kinderbescherming.

CBS Centraal Bureau voor de Statistiek.

$\mathrm{CdB}$ Commissie benoemd door Burgemeester en Wethouders der $\mathrm{Ge}$ meente Haarlem

GAAm: Gemeentearchief Amsterdam.

GAAr: Gemeentearchief Arnhem.

GAB: Gemeentearchief Breda.

GADe: Gemeentearchief Delft.

GADo: Gemeentearchief Dordrecht.

GAG: Gemeentearchief 's-Gravenhage.

GAR: Gemeentearchief Rotterdam.

GAU: Gemeentearchief Utrecht.

GAV: Gemeentearchief Vlaardingen.

GAZ: Gemeentearchief Zwolle.

J\&B: Jeugd en Beroep.

NVNBO: Nederlandsche Vereeniging Nazorg Buitengewoon Onderwijs.

PAIS: Geen afkorting, naam van het blad van O\&A rond de Eerste Wereld oorlog.

PNB: Psychiatrische en Neurologische Bladen.

SJB Archief Stichting Jan Baptist Maastricht.

TBO Tijdschrift voor Buitengewoon Onderwijs.

TNW: Tijdschrift van de Nederlandsche Werkloosheidsraad.

TSG: Tijdschrift voor Sociale Geneeskunde.

TRB: Tijdschrift voor R.K. Buitengewoon Lager Onderwijs.

TvZ: Tijdschrift voor Ziekenverpleging.

TZZ: Tijdschrift voor Zwakzinnigenzorg.

\section{Noten hoofdstuk 1}

1 De Boer, geciteerd in Brants en Van Gennep 1992: 17.

${ }^{2}$ Zie onder andere Boekholt en De Booy 1987.

${ }^{3}$ Zie voor een beschrijving van deze ontwikkeling Graas 1996.

${ }^{4}$ Elias 1987.

${ }^{5}$ Zie onder andere Foucault 1989.

${ }^{6}$ Zie onder andere Jak 1993, 25-29 voor een kort overzicht.

7 De Regt 1984: 28-29.

${ }^{8}$ Zie onder andere Noordman 1989: 19.

${ }^{9}$ Zie De Regt 1984.

${ }_{11}^{10}$ Marx en Engels, 1979: 53.

11 Het denken van Foucault sluit hier op aan. Zie Foucault 1989.

${ }^{12}$ Donzelot 1977.

${ }^{13}$ De Regt 1984: 137.

${ }^{14}$ Blok 1993: 18.

${ }^{15}$ Van Koldam 1987. 


\section{Noten hoofdstuk 2}

${ }^{16}$ Van Wijhe 1902

${ }^{17}$ Mans 1998: 27-29.

${ }^{18} \mathrm{Zie}$ onder andere Jak 1993: 4. Voor een overzicht van de vroege pogingen tot onderwijs aan zwakzinnigen in de negentiende eeuw, zie Bosma 1987.

${ }^{19}$ Zie Willemse 1987 en Bosma 1990.

${ }^{20}$ Klootsema 1904: 29

${ }^{21}$ ibidem

${ }^{22}$ Bosma 1989: 354.

${ }^{23}$ Van Wijhe 1902: 12.

${ }^{24}$ Graas 1996: 148.

${ }^{25}$ Klootsema 1904: 31-32

${ }^{26}$ Schuurmans Stekhoven, PNB 1915: 554-556.

${ }^{27}$ Rose 1985: 106-107

${ }^{28}$ Zie voor de ontwikkeling van het begrip Feeble-Mindedness in Groot-Brittannië Rose 1985.

${ }^{29}$ Noordman 1989: 83.

${ }^{30}$ Bartels 1916.

${ }^{31}$ Voor een uitputtende behandeling, zie Brants 1997.

${ }^{32}$ Noordman 1989: 177.

${ }^{33}$ Schuurmans Stekhoven, TZZ 1913: 6.

${ }^{34}$ zie onder andere Centrale Vereeniging ter behartiging van de Maatschappelijke Belangen van Zwakzinnigen, GAAm R 1541.13

${ }^{35}$ Werlinder 1978: 95

${ }^{36}$ Van Voorthuijsen, PAIS 1917,155-156.

${ }^{37}$ Dortsche Courant d.d. 4-1-1912, GADo.

${ }^{38}$ Supheert en Van Voorthuijsen, PAIS 1917: 98.

${ }^{39}$ Scheffener, PAIS 1917: 124.

${ }^{40}$ Zie Obreen, TZZ 1916. Deze wet was niet specifiek op psychopathen of mensen met een geestelijke stoornis gericht, maar werd door de psychiatrie, zoals blijkt uit de discussies over het onderwerp in het Tijdschrift voor Zwakzinnigenzorg, wel als zodanig beschouwd.

${ }^{41}$ Zie Van Deventer e.a., PNB 1915. Officiële titel van dit wetsontwerp was: Wet van den 28sten Mei 1925, tot aanvulling en wijziging der bepalingen betreffende het strafrecht en de strafrechtspleging ten aanzien van personen bij wie tijdens het begaan van het feit gebrekkige ontwikkeling of ziekelijke storing der geestesvermogens bestond. Zie Hofstee 1987: 106.

${ }^{42}$ Hofstee 1987: 105-106.

43 Jak 1993: 15.

${ }^{44}$ Stuurman 1983: 236.

${ }^{45}$ Zie onder andere Van der Ploeg en Zinkstok 1986: 166.

${ }^{46}$ Zie hiervoor De Regt 1984 en Schuursma 2000: 80.

${ }^{47}$ Van Nijnatten 1986: 27. Zie ook Bartels 1980.

${ }^{48} \mathrm{Zie}$ onder andere Schuursma 2000: 89-100.

${ }^{49}$ Zie onder andere Stuurman 1983.

${ }^{50}$ Bervoets 1999: 30.

${ }^{51}$ Mans 1998: 240.

${ }^{52}$ Zie hiervoor Veld 1987.

${ }^{53}$ Van Wijhe 1902: 15.

${ }^{54}$ Graas 1996: 37-38, Van Gennep 1981: 22. 
${ }^{55}$ De Greve 1901: 7.

${ }^{56}$ Kanner 1977: 90.

${ }^{57}$ Van Wijhe 1902: 32-34.

${ }^{58}$ De Haan, PAIS 1918: 49.

${ }^{59}$ Klootsema 1904: 12.

${ }^{60}$ Van Wijhe 1902: 17.

${ }^{61}$ De Haan, PAIS 1918: 50.

${ }^{62}$ Graas 1996: 101.

${ }^{63}$ Van Wijhe 1901: 19.

${ }^{64}$ Graas 1996: 41.

${ }^{65}$ ibidem

${ }^{66}$ Zie voor een behandeling van het verschijnsel 'schoolarts' Janssen 1990.

${ }^{67}$ Herderschêe, PAIS 1917: 161-162. Goddard was vanaf 1906 de eerste directeur van de Vineland Training School, de Verenigde Staten en was een invloedrijke publicist over zwakzinnigheid. Hij richtte het eerste laboratorium in voor de wetenschappelijke bestudering van zwakzinnigheid. Zie Scheerenberger 1983: 144.

${ }^{68}$ De Boer, TBO 1923: 180.

${ }^{69}$ Van der Ploeg z.j.: 13.

${ }^{70}$ Graas 1996: 35-36.

${ }^{71}$ Zie onder andere De Greve 1901.

${ }^{72}$ Van Wijhe 1901: 7, zie ook Graas 1996: 197-199.

${ }^{73}$ Graas 1996: 205.

${ }_{75}^{74}$ Herderschêe, Onderwijsverslag over 1913-1914: 244.

${ }^{75}$ Graas 1996: 207-208, zie ook Mans 1998: 248-250 en Van Gennep 1977: 16. In 1960 werd deze test nog op $67 \%$ van de debielenscholen gebruikt.

${ }^{76}$ Uit het réorganisatierapport van de afd. Amsterdam van het B.v.N.O. 1921: 100.

77 Graas 1996: 179-180.

${ }^{78}$ Graas 1996: 120.

79 Graas 1996: 124

${ }^{80}$ Graas 1996: 121-122.

${ }^{81}$ Verslag BLO Arnhem 1911, Onderwijsverslag over 1911-1912: 244-245.

${ }^{82}$ Calliber, PAIS 1919: 38.

${ }^{83}$ Zie bijvoorbeeld Visser, TZZ 1916: 70-71.

${ }^{84} \mathrm{Zie}$ onder andere het verslag van school 2 van het BLO, Amsterdam, Onderwijsverslag over 1912-1913: 240.

${ }^{85}$ A.J. Schreuder, TBO 1935: 33-34

86 Jan Baptist, TRB 1925: 108-110.

${ }^{87}$ Blokpoel, TBO 1921: 180.

${ }^{88}$ ibidem

${ }^{89}$ Zie Van der Grinten 1987: 41-42.

${ }^{90}$ Blokpoel, TBO 1921: 180.

${ }^{91}$ Zie de paragrafen 5.1 en 6.5 .

92 Zie onderwijsverslag over 1911-1912: 262-263.

${ }^{93}$ Zie Bodaan 1927, GAR Archief secretarie afd. onderwijs dossiers 1929, 1190-209.

94 De Haan, TBO 1934: 121.

95 Immig 1913: 134.

96 ibidem

97 ibidem

98 Immig 1913: 16.

${ }^{99}$ Vereeniging 'Zorg voor het Achterlijke Kind' te Rotterdam 1929: 8, 12.

${ }^{100}$ CdB 1924: 35-39.

${ }^{101}$ De Haan, TBO1934: 121. 
${ }^{102}$ Notulenboek afd. Dordrecht, GADo 371-1: 6.

${ }^{103}$ Obreen, TZZ 1913: 29-38.

${ }^{104}$ Van Voorthuijsen, TZZ 1916: 18-19.

${ }^{105}$ Zie onder andere het eerste hoofdstuk van Van Koldam 1987: 1-6.

${ }^{106}$ Van Koldam 1987: 7-9.

${ }^{107}$ Obreen, TZZ 1913: 29-38.

${ }^{108}$ A.J. Schreuder, TZZ 1915: 18-19.

${ }^{109}$ Sissingh, TZZ 1915: 19-21.

${ }^{110}$ Sissingh, TZZ 1916: 17-18.

${ }^{111}$ A.J. Schreuder, TZZ 1916: 100.

${ }^{112}$ Sissingh, TZZ 1916: 101.

${ }^{113}$ Obreen, TZZ 1913: 29-38, 151-158.

${ }^{114}$ Obreen, TZZ 1914: 78-85.

${ }^{115}$ Overbeek, TZZ 1916: 14-15.

${ }^{116}$ Zie onder andere notulen Dordrecht d.d. 25-6-1924, GADo 371-40, 371-41 en Van Koldam 1987: 1-6.

117 Verslag BLO Den Haag, GAG bibliotheek p 0671.0

${ }_{118}$ Onderwijsverslag 1914-1915: 208.

${ }^{119}$ Notulenboek afd. Dordrecht, GADo 371-1: 26

${ }^{120}$ Wepster, PAIS 1917: 158.

${ }^{121}$ ibidem

${ }^{122}$ CdB 1924, 25.

${ }^{123}$ Schuursma 2000: 312-313.

${ }^{124}$ Wepster 1928: 3 .

${ }^{125}$ Notulenboek afd. Dordrecht, GADo 371-1: 34.

${ }^{126}$ Wepster, TBO 1923: 169.

${ }^{127}$ Zie Van der Grinten 1986: 42-43. Verschillende van deze afdelingen zouden zich later ontwikkelen tot onafhankelijke organisaties en zich ook bezig gaan houden met (licht)zwakzinnigen. De vereniging zélf, die wat de doelstellingen betreft aansluit bij de eerdere ontwikkelingen binnen de Vereniging ter behartiging van de belangen van zwakzinnigen, ging uiteindelijk in 1924 failliet, omdat de overheid de financiële steun stopzette.

${ }^{128}$ Wepster 1928: 4 .

${ }^{129}$ ibidem

${ }^{130}$ Wepster, TBO 1923, 170.

${ }^{131}$ Voor een overzicht van de ontwikkeling van werkhuizen, zie onder andere Van der Ploeg en Zinkstok 1986: 121 e.v.

\section{Noten hoofdstuk 3}

${ }_{132}$ Bouman e.a. 1917, geciteerd door Kingma 1984: 82.

${ }^{133}$ Zie Graas 1996: 38.

${ }^{131}$ GAAm, Gemeenteblad Amsterdam 1923: eerste blad, 1478.

${ }^{135}$ Onderwijsverslag over 1911-1912: 265-266.

${ }^{136}$ Onderwijsverslag over 1911-1912: 266.

${ }^{137}$ Onderwijsverslag over 1912-1913: 240 .

${ }_{138}^{138}$ Onderwijsverslag over 1912-1913: 241.

${ }_{91}^{139}$ Onderwijsverslag over 1913-1814: 219.

${ }^{91}$ De Boer en Hoogland 1928: 71.

${ }^{141}$ De Boer en Hoogland 1928: 71.

Bouman e.a. 1917, geciteerd door: Kingma 1984: 79.

${ }^{94}$ Bouman e.a. 1917, geciteerd door Kingma 1984: 80. 


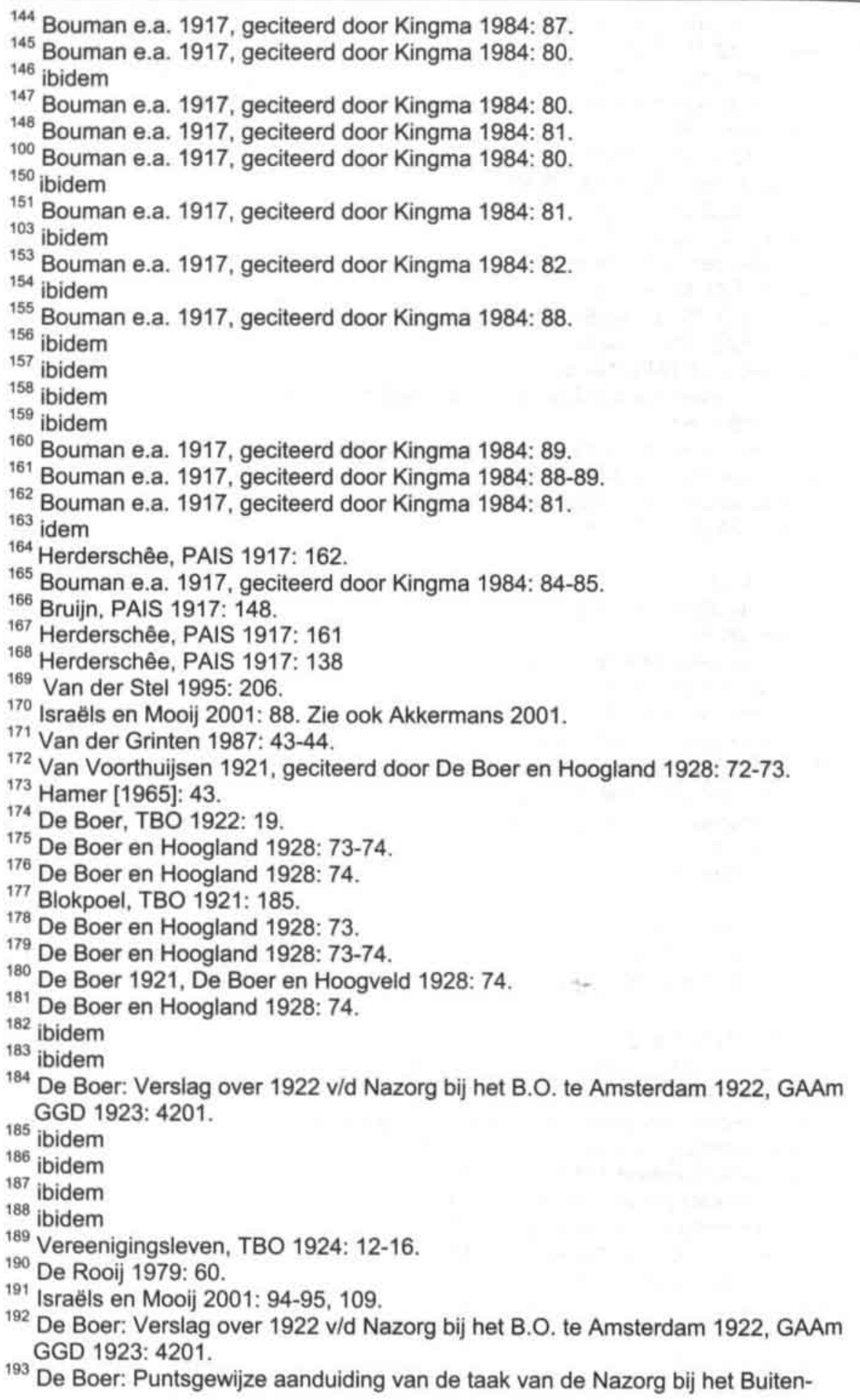


194 ibidem

${ }^{195}$ De Boer, Puntsgewijze aanduiding van de taak van de Nazorg bij het Buitengewoon Onderwijs, GAAm GGD 1923: 4277: 4.

196 De Boer, Een werkinrichting voor imbecillen, GAAm GGD 1923: 4277 in 1923: 4201: 2 .

197 ibidem

${ }^{198}$ De Boer, Een werkinrichting voor imbecillen, GAAm GGD 1923: 4277 in 1923: 4201: 3 .

${ }^{199}$ De Boer, Een werkinrichting voor imbecillen, GAAm GGD 1923: 4277 in 1923: 4201: 4 .

${ }^{200}$ Zie het volgende hoofdstuk.

${ }^{201}$ De Boer, Een werkinrichting voor imbecillen, GAAm GGD 1923: 4277 in 1923: 4201: 3-4.

${ }^{202}$ De Boer, Een werkinrichting voor imbecillen, GAAm GGD 1923: 4277 in 1923: 4201: 4 .

${ }^{203}$ College van B\&W Amsterdam, brief d.d. 14-2-1925, GAAm GGD 1925: 108, 1924 : 3170 .

${ }^{204}$ Meijers, F.S., brief d.d. 24-10-1924, GAAm GGD 1924: 3170.

${ }^{205}$ Van Deventer, PNB 1897, 211-213.

${ }^{206}$ Meijers 1939: 61.

${ }^{207}$ Schuyt, Rapport over de Werkinrichting voor Maatschappelijk Ongeschikte Zwakzinnigen te Haarlem, 1925, bijlage 3b, GAH NA 1521925 A 39 c.

208 ibidem

${ }^{209}$ De Boer, Meijers 1926: 8.

${ }^{210}$ Meijers, F.S., brief d.d. 24-10-1924, GAAm GGD 1924: 3170.

${ }^{211}$ ibidem

${ }^{212}$ Boer, P. de, brief d.d. 18-10-1924, GAAm GGD 1924: 3299 in 1924: 3170.

${ }^{213}$ Heijermans, L., brief d.d. 10-1-1925, GAAm GGD 1925: 108 in 1924: 3170.

${ }^{214}$ College van B\&W Amsterdam, brief d.d. 14-2-1925, GAAm GGD 1925: 108 in 1924: 3170

${ }^{215}$ Wethouder OGMS Amsterdam, brief d.d. 18-7-1925, GAAm GGD 1925: 2454 in 1924: 3170.

${ }^{216}$ Zie Graas 1996: 40.

${ }^{217}$ Conferentie van de directeur van de GGD met de heren Schreuder en Edens, directeuren van de beide scholen voor BLO en de doktoren Herderschêe, Deyll en Meijers, d.d. 21-4-'25, GAAm GGD 1925:1564 in 1924: 3127.

${ }^{218}$ Vergadering inzake bezinkingsklassen d.d. 3-6-'25, GAA GGD 1925: 3127.

${ }^{219}$ Brief van Heijermans d.d. 28-7-'25, GAAm GGD 1925: 2559 in 1924: 3127.

220 Brief van Deyll d.d. 2-12-'27, GAAm GGD 1927: 2342 in 1924: 3127.

\section{Noten hoofdstuk 4}

${ }^{221} \mathrm{CdB}$ 1924: 16

${ }^{222}$ CdB 1924: 2

${ }^{223}$ Hiemstra, TBO 1921: 150.

${ }^{224}$ Zie paragraaf 1.3.3.

225 Berichten, TBO 1922: 160.

226 Schuurmans Stekhoven, TvZ 1924: 663.

227 Schuurmans Stekhoven, TvZ 1924: 664.

${ }^{228}$ CdB 1924: 2 .

229 ibidem

${ }^{230}$ Visser, geciteerd door Schuurmans Stekhoven, TVZ 1924: 665-666. 


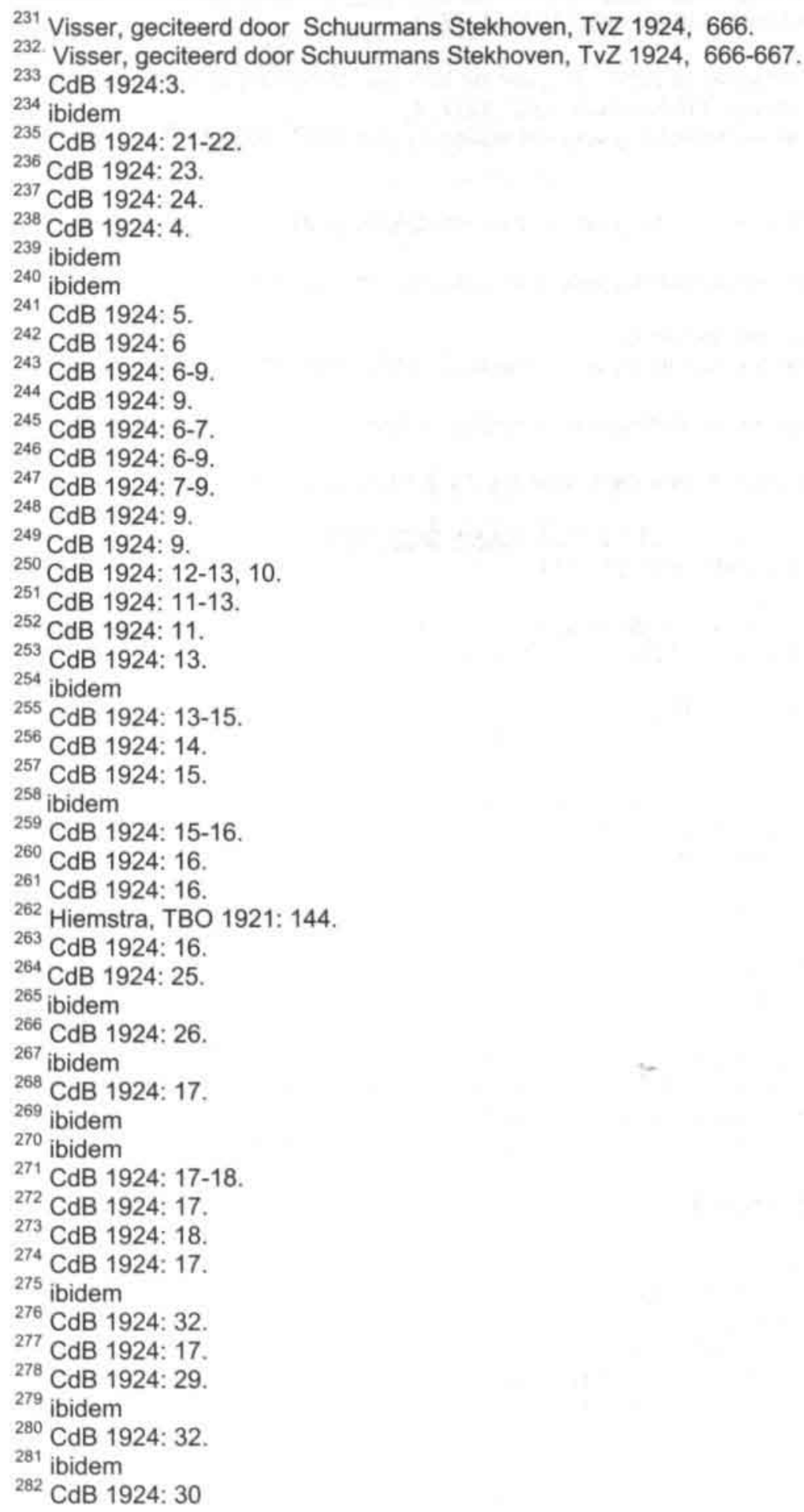




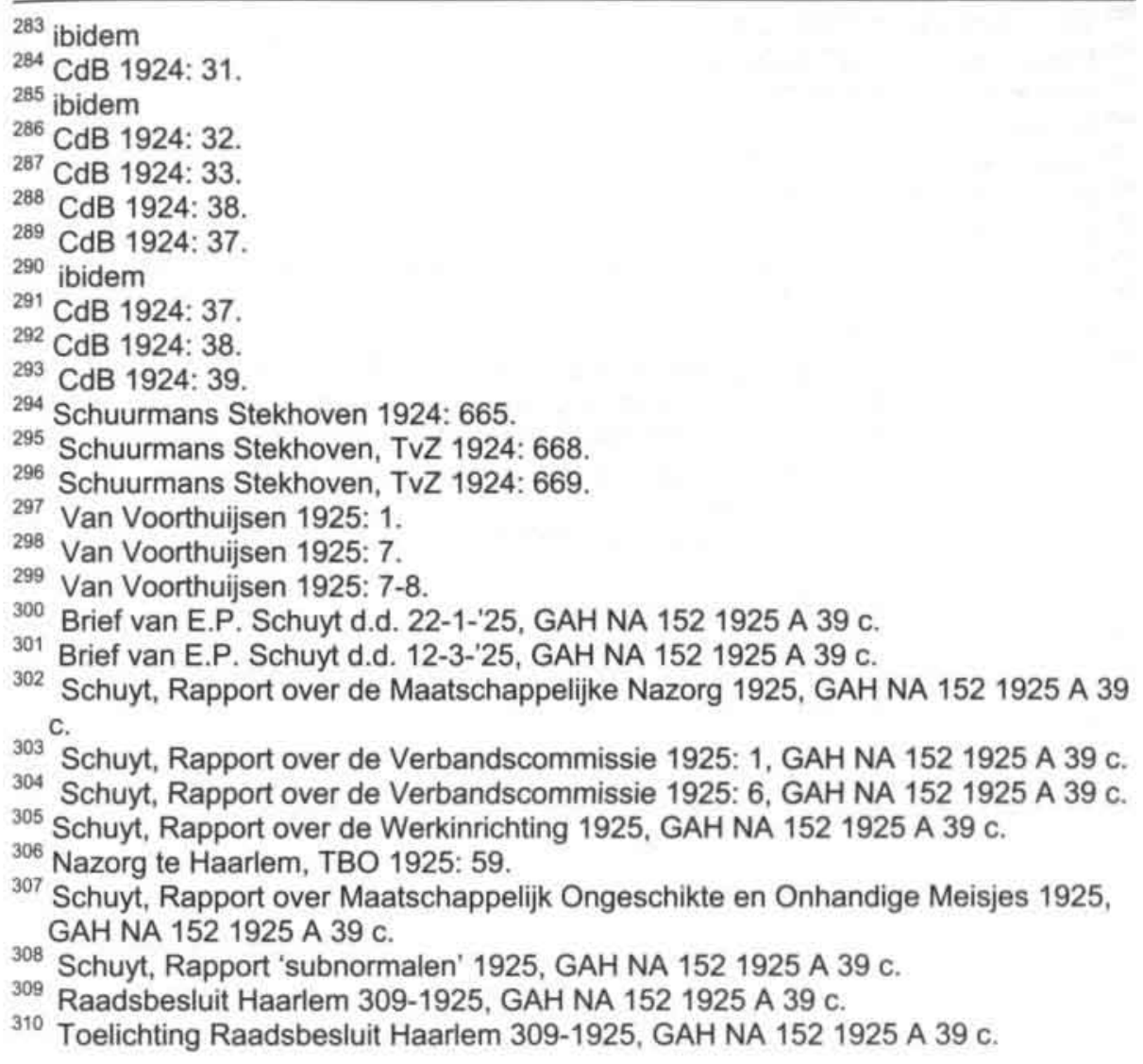

\section{Noten hoofdstuk 5}

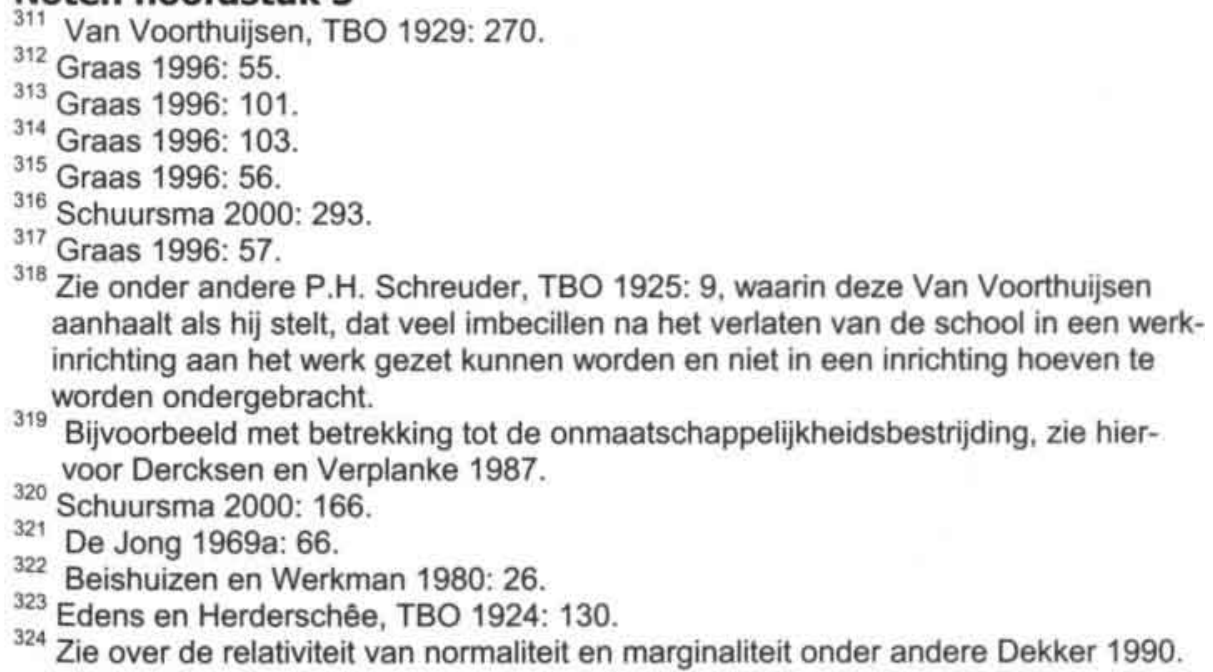


${ }^{325}$ Van Voorthuijsen 1926: 328

${ }^{326}$ Schreuder, A.J., TBO 1930: 24.

${ }^{327}$ Herderschêe, TBO 1925: 159.

328 ibidem

329 School en Nazorg, TRB: 280.

${ }^{330}$ Peelmans, TRB 1927: 112-113.

${ }^{331}$ Grootenboer, TBO 1927: 74 .

${ }^{332}$ Smilders, instemmend geciteerd door Broeder Jan Baptist, TRB 1925: 110.

333 Willemsen, TRB 1927: 175-187.

${ }^{334}$ Vos, TBO 1924: 143

${ }^{335}$ Zie onder andere Schuurmans Stekhoven, TZZ 1913: 6-20, een artikel waarin hij aandringt op het tellen van het aantal 'psychopathen, zwakzinnigen, idioten, krankzinnigen, drankzuchtigen, misdadige elementen' om te onderzoeken of hun aantal steeg. Dat zou een indicatie zijn voor de 'geestelijke welstand' van de $\mathrm{Ne}$ derlandse bevolking als geheel.

Bouman 1924 geciteerd door De Goei 2001: 15.

${ }^{337}$ De Goei 2001: 27.

${ }^{338}$ De Vlugt, geciteerd in Kindermann 1929: 13

339 De Schepper 1991: 34-35.

340 Israëls en Mooij 2001: 103.

341 De Schepper 1991: 30.

${ }^{342}$ De Schepper 1991: 32.

${ }^{343}$ Heijermans e.a. 1930: 1.

344 Israëls en Mooij 2001: 126-127.

345 Detiger 1922: 41 ,

${ }^{346}$ Detiger, TNW 1920: 430.

347 Detiger, TNW 1920: 431-432.

348 Josephus Jitta e.a. 1938: 84-85.

${ }^{349}$ V.d. Duys 1927, AMK 1927: 1500.

350 Josephus Jitta e.a. 1938: 91-92.

351 V.d. Duys, AMK 1927: 1500-1501.

352 Josephus Jitta e.a. 1938: 93.

353 Zie Kindermann, handelingen van het AVO-congres 1929.

354 Detiger, AMK 1930: 2390.

${ }^{355}$ CBS 1930: 26.

${ }^{356}$ Zie onder andere Hoofdbestuur, TBO 1928: 300-303.

357 Zie Josephus Jitta: 1938.

${ }^{358}$ Lietaert Peerbolte, directeur-generaal van het ministerie van volksgezondheid, Kindermann 1929: 18-19.

${ }^{359}$ Mans 1998: 181

${ }^{360}$ H.E., TRB 1926: 18-23.

${ }^{361}$ H.E., TRB 1926: 72 .,

${ }^{362}$ H.E., TRB 1926: $69-70$.

${ }^{363}$ H.E., TRB 1926: 72.

${ }^{364}$ Benignus, TRB 1926: 58.

${ }^{365}$ Calliber, TRB 1926: 88-89.

${ }^{366}$ Willemsen 1926: 109.

${ }^{367}$ De Boer 1926: 341-359.

${ }^{368}$ De Boer 1926: 352.

369 ibidem

${ }^{370}$ De Boer 1926: 352-353.

${ }^{371}$ De Boer 1926: 353. 
${ }^{372}$ De Boer 1926: 354.

${ }^{373}$ De Boer 1926: 353.

${ }^{374}$ De Boer 1926: 354.

${ }^{375}$ Kindermann 1929, 105.

${ }^{376}$ André geciteerd, De Boer 1926: 355.

377 ibidem

${ }^{378}$ De Boer 1926: 356.

${ }^{379}$ De Boer 1928.

${ }^{380}$ De Boer 1928: 24.

${ }^{381}$ André geciteerd in Kindermann 1929: 105.

382 ibidem

${ }^{383}$ Denneboom geciteerd in Kindermann1929: 105-106.

${ }^{384}$ Kindermann 1929: 106.

385 ibidem.

${ }^{386}$ De Boer geciteerd in Kindermann 1929: 110.

387 Zie o.a. Brants en Van Gennep 1992: 19.

${ }^{388}$ Visser, TBO 1928: 235.

389 De Boer 1926: 357.

390 De Boer, J\&B 1928: 189.

391 De Boer, J\&B 1928: 189-191.

392 De Boer, J\&B 1928: 190.

${ }^{393}$ De Boer, J\&B 1928: 189.

394 De Boer, J\&B 1928: 190.

${ }^{395}$ De Boer, J\&B 1928: 190 -191.

${ }^{396}$ De Boer, TBO 1923: 181.

${ }^{397}$ Visser, TBO 1928: 238.

${ }^{398}$ De Boer, P.H. Schreuder e.a. 1929: 141.

${ }^{399}$ De Boer, J\&B 1928: 227-228.

400 ibidem

${ }^{401}$ Scholz en Gregor: 1922.

${ }^{402}$ De Boer, J\&B 1928: 191.

${ }^{403}$ ibidem

404 ibidem

405. CdB 1924: 13.

${ }^{406}$ Van der Ploeg, G. J., TBO 1927: 245.

407 Van der Ploeg, G. J., TBO 1927: 247.

${ }^{408}$ De Boer, J\&B 1928: 228.

${ }^{409}$ F.S. Meijers geciteerd door G.J. van der Ploeg, TBO 1927: 248.

410 TBO Berichten 1928 192-136.

411 Bijvoegsel tot de Nederlandsche Staatscourant 17-5-1920: GAV 8C58.

${ }^{412}$ Zie onder andere Kingma 1984: 69.

${ }^{413}$ Roos en Frantsen, TBO 1925: 176.

${ }^{414}$ Christ, TRB 1928: 173.

${ }^{415}$ Berichten, TBO 1927: 19-20.

${ }^{416}$ Berichten, TBO 1928: 220.

${ }^{417}$ Berichten, TBO 1930: 86-89.

${ }^{418}$ Berichten, TBO 1928: 132-136.

${ }^{419}$ Berichten, TBO 1928: 189-192.

${ }^{420}$ Notulenboek Vereniging Nazorg Delft 1926-1928 d.d. 11-6-'26: GADe 102 - 1.

${ }^{421}$ Notulenboek Vereniging Nazorg Delft1926-1928 d.d. 16-9-'26: GADe 102 - 1.

422 Statuten Vereniging Nazorg Delft: GADe 102 - 1.

${ }^{423}$ Notulenboek Vereniging Nazorg Delft 1926-1928: GADe $102-1$. 
${ }^{424}$ ibidem

${ }^{425}$ Zie onder andere Van Voorthuijsen 1925, Van Voorthuijsen, TRB 1925: 129-132, Van Voorthuijsen, TRB 1927: 9-12, 34-37, 48-51.

${ }^{426}$ Notulenboek Vereniging Zwakzinnigenzorg Utrecht 1927-1934 d.d. 3-2-1927, GAU 369 - 1.

427 ibidem

428 ibidem

429 ibidem

430 Jaarverslag 1927 Vereniging Zwakzinnigenzorg Utrecht, GAU 369 - 1.

431 ibidem

432 Berichten, TBO 1930: 182-183

${ }^{433}$ Berichten, TBO 1930: 129-130.

${ }^{434}$ Berichten, TBO 1927: 212.

435 Berichten, TBO 1928: 274-278.

${ }^{436}$ Berichten, TBO 1928: 132-136.

${ }^{437}$ Berichten, TBO 1931: 176-178.

${ }^{438}$ Van Ginkel, TBO 1928: 19-20.

${ }^{439}$ Van Ginkel, TBO 1928: 74.

440 ibidem

441 Berichten, TBO 1928: 76.

${ }^{442}$ Berichten, TBO 1929: 149-152.

${ }^{443}$ Berichten, TBO 1928: 75-76.

${ }^{444}$ Berichten, TBO 1935: 262-267.

445 De Boer, TBO 1932: 231.

${ }^{446}$ Willemsen 2001:29.

447 Willemsen 2001: 31.

${ }^{448}$ Vereeniging voor Nazorg, TRB 1931: 27.

${ }^{449}$ ibidem

${ }^{450}$ Potters 1949: 1.

${ }^{451}$ ibidem

452 ibidem

${ }^{453}$ Berichten, TBO 1929: 63-65.

454 Zie Van Koldam 1987.

${ }^{455}$ Vereeniging 'Zorg voor het achterlijke kind' te Rotterdam 1914-1929 [1929]: 5.

456 ibidem

${ }^{457}$ Visser, TBO 1928: 244.

${ }^{458}$ Brief van 8-7-1929: GAR 351.01b, dossiers 1929: 1190-209.

459 GAR 351.01b, dossiers 1929: 1190-209.

${ }^{460}$ Koning e.a. 1931: 6.

${ }^{461}$ Koning e.a. 1931: 3 .

462 Koning e.a. 1931: 19 .

${ }^{463}$ CBS 1930: 17.

${ }^{464}$ Potters 1949: 4 .

${ }^{465}$ Heijermans 1930: 59.

${ }^{466}$ Koning e.a. 1931: 37-38, 63.

${ }^{467}$ Notulenboek Vereniging Nazorg 1928-1943 d.d. 27-12-'28, GADe 1021.

${ }^{468}$ Koning e.a. 1931:137.

${ }^{469}$ GAR 351.01 b, dossiers 1929: 1190-209 en brief d.d. 18-7-1925, GAAm GGD 1924: 3170.

470 Jaarverslag vereniging Zwakzinnigenzorg Dordrecht 1928, GADo 371: 40.

471 Jaarverslagen vereniging Zwakzinnigenzorg Dordrecht 1925-1930, GADo 371: 40.

472 Jaarversiag vereniging Zwakzinnigenzorg Dordrecht 1924, GADo 371: 40. 
${ }^{473}$ Christ, TRB 1928: 173.

474 Jaarverslagen vereniging Zwakzinnigenzorg Dordrecht 1925-1930, GADo 371: 40.

475 De Boer 1926: 347.

${ }^{476}$ De Boer 1929: 142.

${ }^{477}$ De Boer, TBO 1923: 181.

${ }^{478}$ De Boer, J\&B 1928: 226-227.

${ }^{479}$ De Boer 1926: 348.

${ }^{480}$ Wepster 1929: 157.

${ }^{481}$ Visser, TBO 1928: 236.

${ }^{482}$ Querido, geciteerd in Hamer [1965]: 42.

${ }^{483}$ Dagboeken M. Majoie, SJB.

484 Koning e.a. 1931: 30-34.

${ }^{485}$ De Boer, TBO 1922: 19.

${ }^{486}$ De Boer, TBO 1923: 182.

${ }^{487}$ Dagboeken M. Majoie, SJB.

${ }^{488}$ De Boer, J\&B 1928: 310.

${ }^{489}$ De Boer, J\&B 1928: 312.

${ }^{490}$ Visser 1928, TBO: 235-236.

491 Blokpoel, TBO 1921: 186.

${ }^{492}$ Potters 1949: 1.

${ }^{493}$ Visser 1928, TBO: 236.

${ }^{494}$ Notulen bestuursvergadering vereniging Nazorg Delft d.d. 10-4-'28, GADe 102-1.

495 Visser, TBO 1928: 237.

${ }^{496}$ De Visser, TBO: 1928: 236.

497 De Boer 1926: 359.

${ }^{498}$ De Boer 1926: 358.

${ }^{499}$ De Boer, Meijers 1926: 7.

500 Kindermann 1929: 125

${ }^{501}$ Kindermann 1929: 124, 234.

502 Kindermann 1929: 302.

${ }^{503}$ Berichten, TBO 1927: 20.

${ }^{504}$ De Boer 1929: 142-143.

${ }^{505}$ Notulenboek bestuur vereniging Zwakzinnigenzorg 1927-1934: 57, GAU 369.

${ }^{506}$ Wepster 1928: 6 .

${ }^{507}$ Kindermann 1929: 301.

${ }^{508}$ Notulenboek bestuur vereniging Zwakzinnigenzorg 1927-1934: 24, GAU 369.

${ }^{509}$ Schuyt, Rapport over de Maatschappelijk Ongeschikte - en Onhandige Meisjes, GAH NA 1521925 A 39 c.

510 Jaarverslag Vereniging zwakzinnigenzorg Dordrecht 1926: 2, GADo 371: 40.

${ }^{511}$ Wepster 1928: 6.

${ }^{512}$ De Boer, Kindermann 1929: 110.

513 ibidem

514 ibidem

${ }^{515}$ Peelmans, TBO 1928: 218.

${ }^{516}$ Schuyt 1929: 109 .

${ }^{517}$ Graas 1996: 103.

${ }^{518}$ Gedenkboek omtrent zorg voor en onderwijs aan zwakzinnigen 1929: 179.

${ }^{519}$ Hoofdbestuur, TBO 1927: 64.

${ }^{520}$ Schuyt 1925, GAH NA 1521925 A 39 c.

${ }^{521}$ Bouman e.a. 1917, geciteerd in Kingma 1984: 87.

${ }^{522}$ Algemeene vergadering op 16 april 1927, het gebouw van kunsten en wetenschappen te Utrecht, TBO 1927: 132. 
${ }^{523}$ Zie paragraaf 2.4

${ }^{524}$ Algemeene vergadering op 16 april 1927, TBO 1927: 133.

525 ibidem

${ }^{526}$ Algemeene vergadering op 16 april 1927, TBO 1927: 134 .

${ }^{527}$ Algemeene vergadering op 16 april 1927, TBO 1927: 136.

${ }^{528}$ Visser, TBO 1928: 228.

${ }^{529}$ Visser, TBO 1928: 98.

${ }^{530}$ Visser, TBO 1928: 100 .

${ }^{531}$ Wepster 1928:10.

\section{Noten hoofdstuk 6}

${ }^{532}$ Van der Ploeg, z.j.: 15-16.

${ }^{533}$ De Jong 1969a: 107.

534 Beishuizen en Werkman 1980: 231.

535 De Jong 1969a: 195.

${ }^{536}$ De Rooy 1978: 76.

${ }^{537}$ Noordman 1989: 171, 198.

${ }^{538}$ Duitsland en de zorg voor minderwaardigen, TBO 1933: 168 ,

${ }^{539}$ Boek en tijdschrift, TBO 1933: 237-238.

540 Zie Mans 1998: 225-226.

541 Berichten, TBO 1934: 21.

${ }^{542} \mathrm{Fr}$. Visser, TBO 1936: 122.

${ }^{543}$ Van der Wal, TBO 1939: 78-87, 105-107.

544 Josephus Jitta e.a. 1938: 60. Zie ook Noordman 1989: 199.

${ }^{545}$ M. Ph., Fr., TRB 1933: 246 . .

${ }^{546}$ Noordman 1989: 176.

${ }^{547}$ Verslag van de R.K. Stichting ' Zwakzinnigenzorg' te Maastricht 1937: 2.

${ }^{548}$ Koenen 1933: 70.

${ }^{549}$ Mededeelingen, TRB 1934: 155-156.

550 Noordman 1989: 209.

${ }^{551}$ Blanken, TBO 1935: 242.

${ }^{552}$ Berichten, TBO 1934: 242.

553 ibidem

${ }^{554}$ Herderschêe 1934.

${ }^{555}$ Noordman 1989: 126.

${ }^{556}$ Koning, TBO 1931: 130.

${ }^{557}$ Herderschêe, TBO 1930: 126.

558 Herderschee, TSG 1933: 27.

559 Herderschêe, TSG 1933: 34 .

${ }^{560}$ Herderschee, TSG 1933: 27.

${ }^{561}$ Herderschêe, TBO 1930: 126.

562 Herderschêe 1934: 111.

${ }^{563}$ Herderschêe, TBO 1937: 50.

${ }^{564}$ Van Voorthuijsen, TBO 1930: 101.

${ }^{565}$ Van Voorthuijsen, TBO 1930: 105.

566 Opening van de vierde leergang voor B.O., TBO 1931: 233-234.

${ }^{567}$ Van Voorthuijsen, TBO 1932: 7.

${ }^{568}$ Van Voorthuijsen, TBO 1936: 57-63, 76-78.

${ }^{569}$ Van Voorthuijsen, TBO 1936: 191.

570 ibidem

571 Polderman, TBO 1934: 143. 
572 Polderman, TBO 1934: 144.

${ }^{573}$ Douglas Turner, TBO 1933: 112-118.

${ }^{574}$ Het betreft hier het onderzoek op grond waarvan in 1913 in Groot-Brittannië de Mental Deficiency Act tot stand werd gebracht. Zie hierover onder andere Van Voorthuijsen, TBO 1930: 94-108.

${ }^{575}$ Douglas Turner, TBO 1933: 113.

576 ibidem

577 Douglas Turner, TBO 1933: 114.

${ }^{578}$ Douglas Turner, TBO 1933: 115.

579 ibidem

${ }^{580}$ Zie onder andere 'De tweede kursus voor voortgezette vakstudie voor het B.L.O.', TBO 1930: 34-38, waarin Van Voorthuijsen het oorzakelijke verband tussen armoede en zwakzinnigheid bespreekt. In Van Voorthuijsen, TBO 1930: 94-108 gaat hij in op het rapport van de Wood-commissie.

${ }^{581} \mathrm{Fr}$. Visser, TBO 1936: 118-123.

${ }^{582} \mathrm{Fr}$. Visser, TBO 1936: 119.

583 ibidem

${ }^{584} \mathrm{Fr}$. Visser, TBO 1936: 120.

585 ibidem

${ }^{586} \mathrm{Fr}$. Visser, TBO 1936: 119-120.

${ }^{587} \mathrm{Fr}$. Visser, TBO 1936: 121.

${ }^{588} \mathrm{Fr}$. Visser, TBO 1936: 123.

${ }^{589}$ Herderschêe, TBO 1937: 49-50.

${ }^{590}$ Kortenhorst 1931: 9 .

591 Dercksen en Verplanke 1987: 19-20.

${ }^{592}$ Dercksen en Verplanke 1987: 22-24.

${ }^{593}$ Dercksen en Verplanke 1987: 53.

${ }^{594}$ Querido, 1933.

${ }^{595}$ Querido 1933: 21.

596 ibidem

${ }^{597}$ Querido 1933: 22.

${ }^{598}$ ibidem

599

600

Querido 1933: 42.

Querido 1933: 48.

601 Denk hierbij bijvoorbeeld aan J.H.M. Koenen en P.A.F. van der Spek

${ }^{602}$ Boek en tijdschrift, TBO: 72.

603 Josephus Jitta e.a. 1938: 230, 232.

604 Josephus Jitta e.a. 1938: 233.

605 De Boer, TBO 1932: 206-219.

606 Sijes 1990: 45.

${ }^{607}$ De commissie berekende het percentage over alle 1155 oud-leerlingen en niet alleen de 764 van wie de gegevens waren onderzocht. Dat leverde een lager percentrage op van bijna $23 \%$ van de oud-leerlingen die met de politie in aanraking was gekomen. Koning e.a. 1931: 101.

${ }^{608}$ Koning e.a. 1931: 119.

${ }^{609}$ Van Voorthuijsen, TBO 1934: 92.

${ }^{610}$ Van Voorthuijsen, TBO 1930: 101.

${ }^{611}$ Provinciale Commissie voor Zwakzinnigenzorg, Noord-Brabant, TRB 1931: 282 283.

612 Koenen 1933: 61 .

${ }^{613}$ Berichten, TBO 1934: 128.

${ }^{614}$ Notulenschrift NVNBO d.d. 9-6-1934, GAAm 1071 SPZ 1. 
${ }^{615}$ Het betreft hier een onderzoek van Schenk, 'Wangedrag bij kinderen'. Hij stelde vast, dat $7 \%$ van de strafrechtelijk behandelde zaken van jongens de betrokkene 'ernstig achterlijk' was, terwijl slechts 2 à $3 \%$ van de totale bevolking 'ernstig achterlijk' was. Zie Van Bemmelen, 1939: 68.

${ }^{616}$ Een niet nader genoemd Duits onderzoek zou dit uitwijzen. Het werd door De Boer aangehaald in een artikel in het tijdschrift voor reclassering. Zie Van Bemmelen, 1939: 70.

${ }^{617}$ Notulen NVNBO d.d. 8-10-1938.

${ }^{618} \mathrm{Fr}$. Visser, TBO 1938: 270.

619 ibidem

${ }^{620} \mathrm{Fr}$. Visser, TBO 1938: 270-281.

${ }^{621} \mathrm{Fr}$. Visser, TBO 1938: 280.

622 ibidem

${ }^{623}$ Van Bemmelen 1939: 70.

624 ibidem.

${ }^{625}$ De Boer 1939: 36.

${ }^{626}$ De Boer 1939: 35.

${ }^{627}$ De Boer 1939: 33-34.

${ }^{628}$ De Boer 1939: 34.

${ }^{629}$ De Boer 1939: 39.

${ }^{630}$ De Boer 1939: 37.

631 ibidem

${ }^{632}$ Carp 1939: 53.

${ }^{633}$ Wiersma, TBO 1940: 93.

634 Graas 1996: 106.

${ }^{635}$ Berichten, TBO 1930: 153-156.

${ }^{636}$ Berichten, TBO 1934: 65-70.

637 Berichten, TBO 1930: 63-65.

${ }^{638}$ Berichten, TBO 1931: 108-109.

${ }^{639}$ Berichten, TBO 1931: 56-57.

${ }^{640}$ Berichten, TBO 1932: 117-118.

641 Jansen, TBO 1934: 272-274.

${ }^{642}$ Opening werkinrichting voor zwakzinnige jongens te Apeldoorn, TBO 1932: 94.

${ }^{643}$ Notulen Bestuur R.K. Stichting Zwakzinnigenzorg d.d. 10-9-'35, SJB.

${ }^{644}$ Notulen 1934-1955 vereniging NABO d.d. 1-4-'35, GAZ VA 25,

${ }^{645}$ Berichten, TBO 1936: 234-236.

${ }^{646}$ V., TBO 1940: 37-38.

${ }^{647}$ Notulenschrift NVNBO d.d. 19-1-31, GAAm 1071 SPZ 1.

648 Bodaan 1927, GAR archief secretarie afd. Onderwijs, dossiers 1929, 1190-209.

${ }^{649}$ Werkinrichting voor zwakzinnigen in Rotterdam-zuid, TRB 1933: 180-182.

${ }^{650}$ Vereeniging 'Zorg voor het achterlijke kind' te Rotterdam: 1939.

651 Jaarverslag 1939 vereeniging 'Zorg en nazorg voor Zwakzinnigen, RotterdamZuid', GAR RB J 140.

${ }^{652}$ Koning e.a. $1931,68$.

653 Koning e.a. 1931: 68.

${ }^{654}$ Koning e.a. 1931: 120.

${ }^{655}$ Koning e.a. 1931: 137.

${ }^{656}$ Koning e.a. 1931: 146.

657 Leeflang, TBO 1933: 229-230.

658 Leeflang. TBO 1933: 229-231.

659 Leeflang, TBO 1935: 30-31, Leeflang, TBO 1936: 53-56, Leeflang, TBO 1940: 3839. 


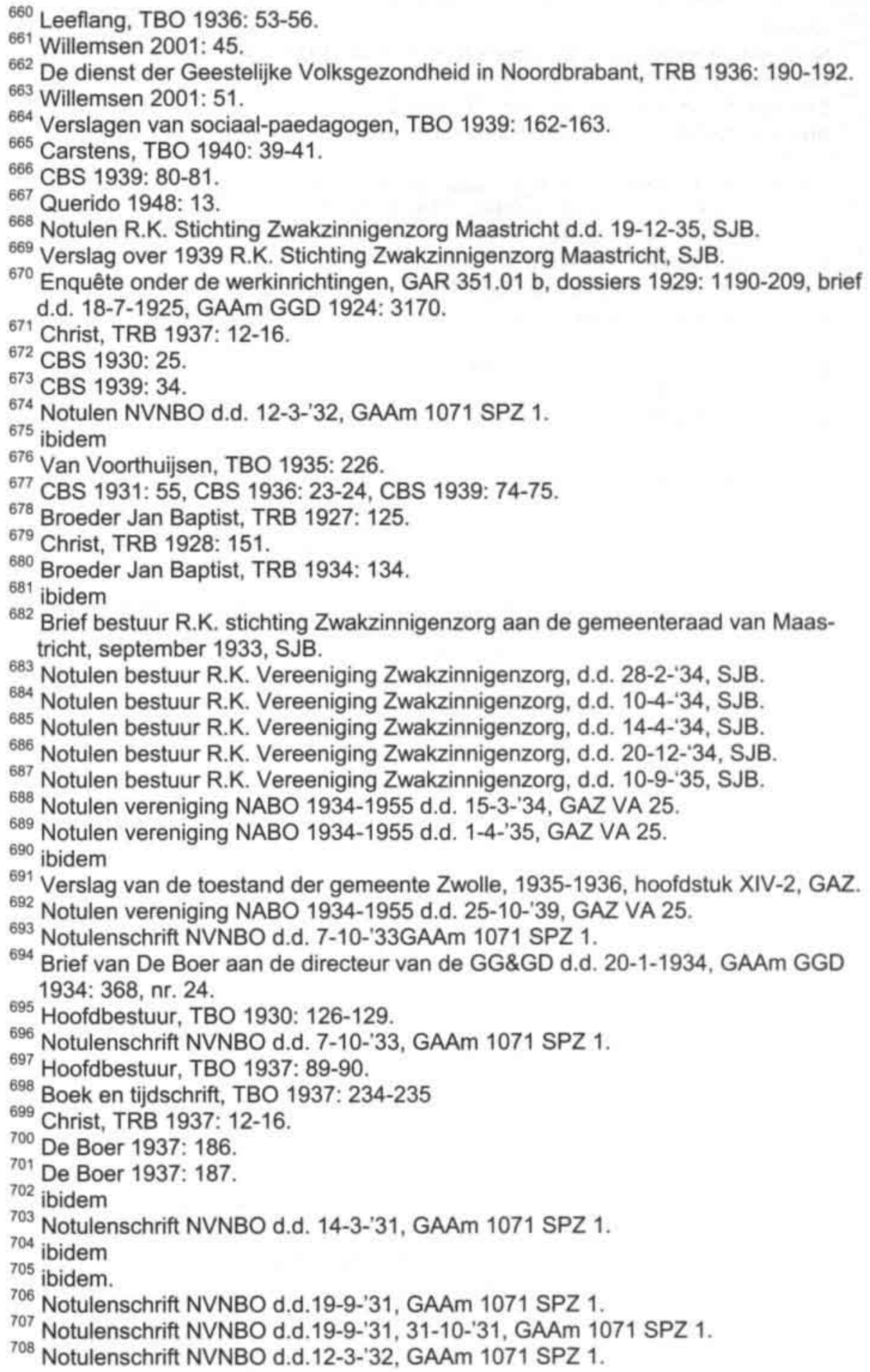


709 ibidem

${ }^{710}$ Nota van de wethouder van onderwijs, d.d. maart 1931, GAR, archief secretarie afd. Onderwijs, dossiers 1929, 1190-209.

${ }^{711}$ Een zeer belangrijke vergadering. TBO 1932: 115-116.

${ }^{712}$ Brief van NVNBO aan Nazorg Utrecht d.d. juni 1935, GAU 369 zwakzinnigenzorg inv. nr. 20.

${ }^{713}$ Chr. Buitengewoon Onderwijs, De Nazorg, TRB 1934: 260-261.

714 Officiële opening Chr. Werkinrichting, TRB 1936: 242.

${ }^{715}$ Berichten, TBO 1932: 93-94.

${ }^{716}$ Berichten, TBO 1933: 126-128.

${ }^{717}$ R.K. Landelijke Nazorgorganisatie, TRB 1935: 292-293.

${ }^{718}$ Broeder Jan Baptist, TRB 1938: 129-144.

719 ibidem

${ }^{720}$ Broeder Jan Baptist, TRB 1941: 133-137.

721 De Boer 1937: 187.

722 Notulenschrift NVNBO d.d. 14-8-'35, GAAm 1071 SPZ 1.

${ }^{723}$ Christ 1937: 48.

${ }^{724}$ Hoofdbestuur, TBO 1935: 129, v.d. Waals, TBO 1936: 82.

725 Jacobs 1937: 28.

${ }^{726}$ De Boer, Verslag van het eerste Nederlandsch Paedagogisch Congres 1926: 355

${ }^{727}$ Notulenschrift NVNBO d.d. 8-4-'33, GAAm 1071 SPZ 1.

728 ibidem

${ }^{729}$ Door de vereniging 'Schroeder van der Kolk', van oorsprong een afdeling van de 'Vereeniging Maatschappelijk Werk bij Zenuwlijders en Krankzinnigheid'. Zie hiervoor Van der Grinten 1987: 43. Gevolg hiervan was dat een eigen werkinrichting voor zwakzinnigen niet van de grond kwam. Oud-leerlingen van het BLO waren daardoor afhankelijk van de werkinrichting van Schroeder van der Kolk.

${ }^{730}$ Notulenschrift NVNBO d.d. 8-6-'35, GAAm 1071 SPZ 1.

731 ibidem

732 Notulenschrift NVNBO d.d. 14-8-'35, GAAm 1071 SPZ 1.

${ }^{733}$ De Schepper 1991: 11-12.

${ }^{734}$ Notulenschrift NVNBO d.d. 14-8-'35, GAAm 1071 SPZ 1.

735 De Boer 1937: 185, 187.

${ }^{736}$ Notulenschrift NVNBO d.d. 14-8-'35, GAAm 1071 SPZ 1.

${ }^{737}$ Notulenschrift NVNBO d.d. 29-2-'36, GAAm 1071 SPZ 1.

${ }^{738}$ Het lidmaatschap kostte fl. 50,- per jaar. Zie ook notulen NVNBO d.d. 8-6-'35, GAAm 1071 SPZ 1.

${ }^{739}$ Zie Notulenschrift NVNBO d.d. 4-7-'36, GAAm 1071 SPZ 1.

${ }^{740}$ Zie notulenschrift NVNBO d.d. 27-2-1937, GAAm 1071 SPZ 1.

${ }^{741}$ Zie onder andere Van der Grinten 1987: 59 e.v.

${ }^{742}$ Notulenschrift NVNBO d.d. 9-6-1934, GAAm 1071 SPZ 1.

743 Josephus Jitta e.a. 1938: 92.

744 De Boer 1937: 187.

745 Josephus Jitta e.a. 1938: 93-94.

746 Josephus Jitta e.a. 1938: 94.

${ }^{747}$ Brief van het bestuur van de afdeling Arnhem van de AVO aan B\&W van Arnhem, GAAr secretarie 1930-1934, $1.842 .3 \mathrm{nr} .31762$.

${ }^{748}$ Notulenschrift NVNBO d.d. 12-3-1932, GAAm 1071 SPZ 1.

${ }^{749}$ Notulenschrift NVNBO d.d. 4-2-'33, GAAm 1071 SPZ 1.

${ }^{750}$ Notulenschrift NVNBO d.d. 15-1-'38, GAAm 1071 SPZ 1.

${ }^{751}$ CBS 1930: 25-26.

${ }^{752}$ CBS 1939: 34 . 
${ }^{753}$ Notulenschrift NVNBO d.d. 27-2-'37, GAAm 1071 SPZ 1.

754 ibidem

${ }^{755}$ Josephus Jitta e.a. 1937: 96-97.

756 Josephus Jitta e.a. 1937: 96.

757 Josephus Jitta e.a. 1937: 98.

${ }^{758}$ De Rooy 1979: 18.

759 De Rooy 1979: 18.

${ }^{760}$ Detiger 1937 geciteerd in (wet) sociale werkvoorziening z.j.: 1 .

761 Josephus Jitta e.a. 1938: 109.

762 Zie onder andere notulenschrift NVNBO d.d. 12-3-1932, GAAm 1071 SPZ 1.

${ }^{763}$ Zie onder andere bestuursnotulen Stichting Zwakzinnigenzorg gevestigd te Maastricht, 14-11-'35, SJB.

${ }^{764}$ Verslag 1939 R.K. Stichting 'Zwakzinnigenzorg' te Maastricht, TBO 1939: 182.

${ }^{765}$ Schuyt, notulenschrift NVNBO d.d. 22-12-1934, GAAm 1071 SPZ 1.

${ }^{766}$ Berichten, TBO: 130.

${ }^{767}$ Notulenschrift NVNBO d.d. 1-10-1932, GAAm 1071 SPZ 1.

768 Josephus Jitta e.a. 1938: 110.

${ }^{769}$ Notulenschrift NVNBO d.d. 22-12-'34, GAAm 1071 SPZ 1.

${ }^{770}$ Zie notulenschrift NVNBO d.d. 8-10-1938, GAAm 1071 SPZ 1.

771 Notulenschrift NVNBO d.d. 31-8-1940, GAAm 1071 SPZ 1.

772 Notulenschrift NVNBO d.d. 28-8-'35, GAAm 1071 SPZ 1.

${ }_{773}$ Notulenschrift NVNBO d.d. 4-7-'36, GAAm 1071 SPZ 1.

774 Notulenschrift NVNBO d.d. 27-2-'37, GAAm 1071 SPZ 1.

775 Notulenschrift NVNBO d.d. 27-2-'37 en 5-6-'37, GAAm 1071 SPZ 1.

${ }^{776}$ Notulenschrift NVNBO d.d. 4-5-40, GAAm 1071 SPZ 1.

777 De Rooy 1979: 60-61.

${ }^{778}$ Koning, J\&B 1930: 76.

${ }^{779}$ De Rooy 1979: 61.

${ }^{780}$ Van Det, J\&B 1931: 112-117, De Boer, J\&B 1931: 179-183, De Boer, J\&B 1931:

781 217-221, Van Det, J\&B 1931: 221-225, Van Det, J\&B 1931: 279-282.

${ }^{81}$ De Boer, J\&B 1931: 221.

\section{Noten hoofdstuk 7}

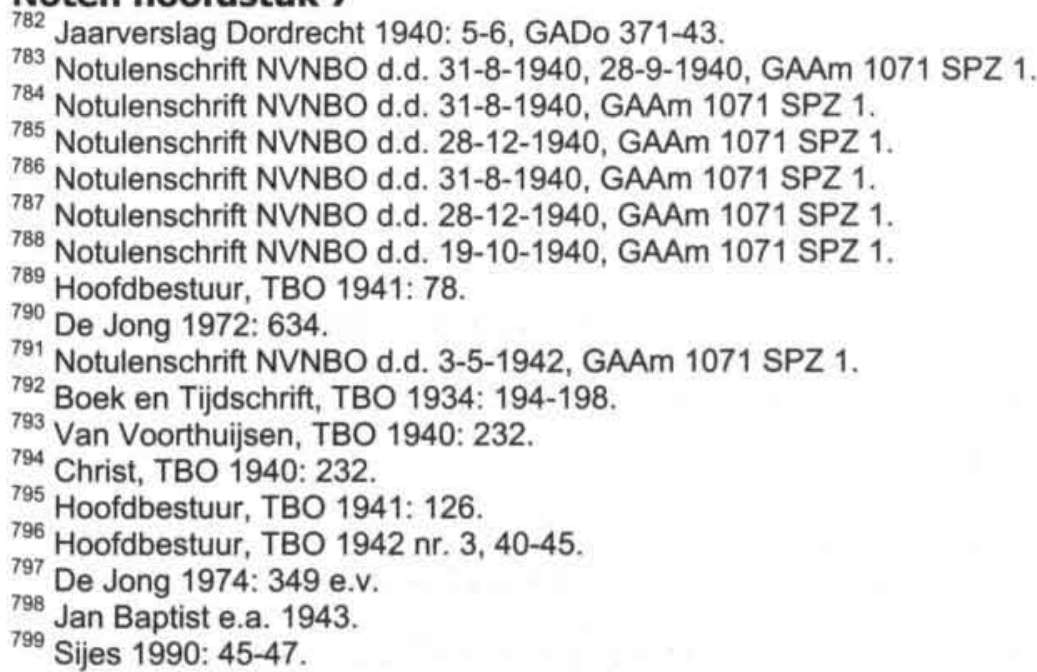


${ }^{800}$ In verband met de viucht van de Nederlandse regering sprak men niet meer van ministeries, de ministers zaten immers in Londen, maar van departementen.

${ }^{801}$ Sijes 1990: 67.

${ }^{802}$ Sijes 1990: 98.

${ }^{803}$ Notulenschrift NVNBO d.d. 3-5-1941, GAAm 1071 SPZ 1.

804 ibidem

${ }^{805}$ ibidem

806 Jaarverslag Dordrecht 1942: 1, GADo 371-43.

807 Jaarverslag Dordrecht 1943: 2, GADo 371-43.

${ }^{808}$ Sijes 1990: 58.

${ }^{809}$ Sijes 1990: 60.

810 Sijes 1990: 37-39.

811 Sijes 1990: 44.

${ }^{812}$ Sijes 1990: 76, 84.

${ }^{813}$ Sijes 1990: 113.

${ }^{814}$ Notulenschrift NVNBO d.d. 6-12-41, GAAm 1071 SPZ 1.

815 ibidem

${ }^{816}$ Van Dijk 1946: 1, GAG bibliotheek P 4591.0.

${ }^{817}$ Van Dijk 1946: 2, GAG bibliotheek P 4591.0.

${ }^{818}$ Verslag der gemeentelijke bemoeiingen betreffende de Nazorg voor de oudleerlingen der scholen voor Buitengewoon Lager Onderwijs te Rotterdam 1941: 3, GAR dossier onderwijs en volksontwikkeling, secr. Afd. onderwijs, dossiers 1942 1340/152, Van Dijk 1946: 2, GAG bibliotheek P 4591.0.

${ }^{819}$ Van Dijk 1945: 1, GAG bibliotheek P 4591.0.

820 Sijes 1990: 398.

${ }^{821}$ De Jong 1980: 64.

${ }^{822}$ Sijes 1990: 544-549, Van Dijk 1946: 2-3, GAG bibliotheek P 4591.0.

${ }^{823}$ Van Dijk 1946: 3, GAG bibliotheek P 4591.0.

${ }^{824}$ Van Voorthuijsen 1941.

${ }^{825}$ Van Voorthuijsen 1941: 8.

${ }^{826}$ Van Voorthuijsen 1941: 14

${ }^{827}$ Van Voorthuijsen 1942: 46-47.

${ }^{828}$ Van Voorthuijsen 1942: 26.

${ }^{829}$ Koning e.a. 1930: 101.

${ }^{830}$ Van Voorthuijsen 1942: 29.

${ }^{831}$ Van Voorthuijsen 1942: 30.

${ }^{832}$ Van Voorthuijsen 1942: 31.

${ }^{833}$ Van Voorthuijsen 1942: 34-35.

${ }^{834}$ Van Voorthuijsen 1942: 36.

${ }^{835}$ Van Voorthuijsen 1942: 33.

${ }^{836}$ Van Voorthuijsen 1942: 48.

${ }^{837}$ Van Voorthuijsen was niet op de hoogte van het angstvallig geheimgehouden euthanasieprogramma dat vanaf het einde van de jaren dertig aan zo'n 100.000 Duitse zwakzinnigen het leven kostte.

${ }^{838}$ Van Houte, TBO 1941: 59.

839 De Jong 1976: 253-254.

${ }^{840}$ Willemsen 2001: 61.

${ }^{841}$ Van Houte, TBO 1941: 60-61.

${ }^{842}$ Brief behorende bij schrijven van 20-9-1940, AGO Diemen.

843 ibidem

${ }^{844}$ Lijst van De Boer, omstreeks september 1941, AGO Diemen.

${ }^{845}$ Brants en Van Gennep, 1992: 23. 


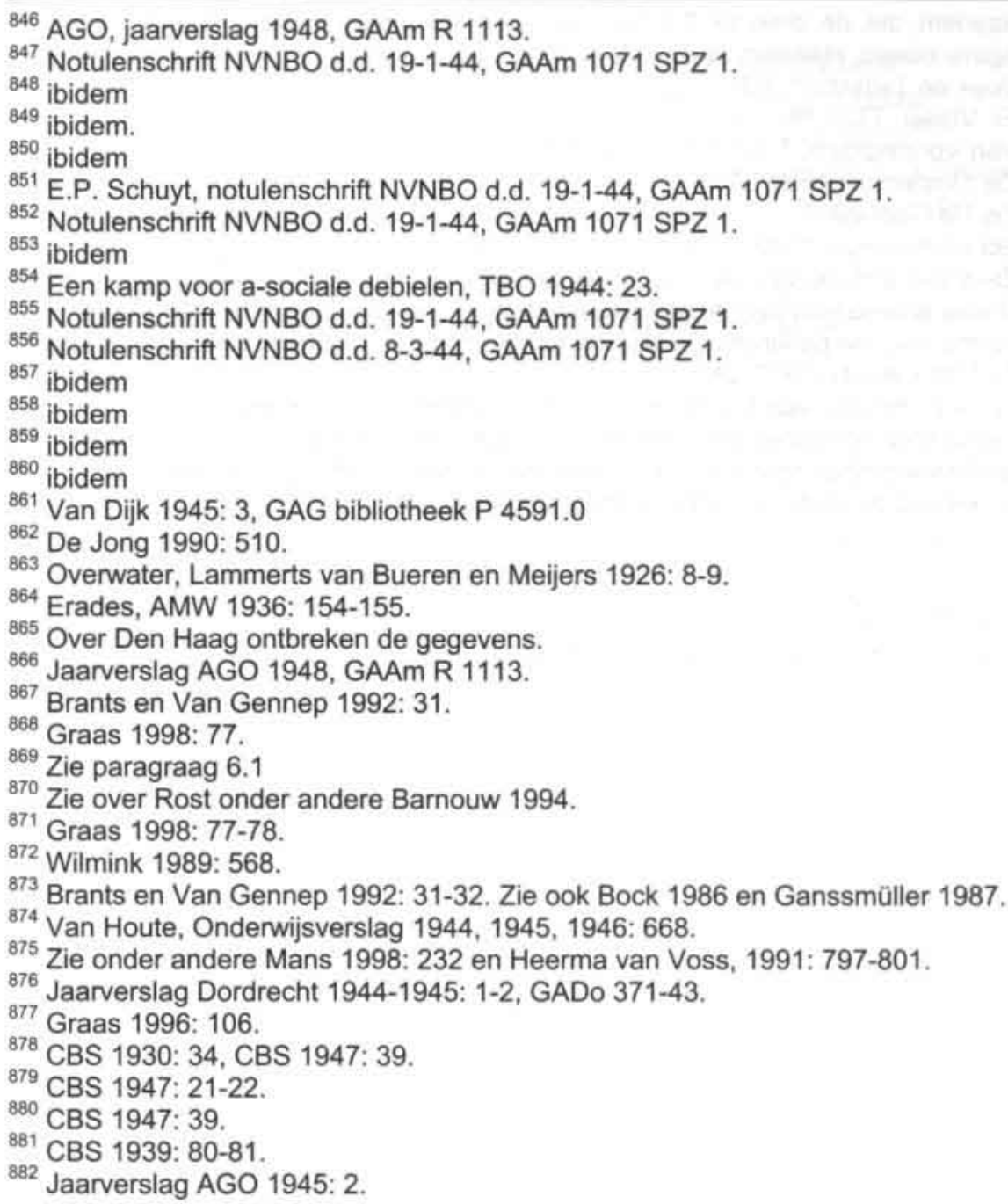

\section{Noten hoofdstuk 8}

${ }^{883}$ Rede E.P. Schuyt d.d. 25-4-1957: 2.

${ }^{884}$ Rede E.P. Schuyt d.d. 25-4-1957: 3.

${ }^{885}$ Edens en Herderschêe, TBO 1930: 142.

${ }^{886}$ De Boer, TBO 1923: 181.

${ }^{887}$ De Boer, TBO 1932: 207.

888 zie onder andere Herderschêe, TBO 1922: 170-171.

${ }^{889}$ Dat een aanzienlijk deel van de oud-leerlingen van scholen voor BLO nadat zij de school hadden verlaten niet langer als zwakzinnig konden worden geclassificeerd, blijkt ook uit later onderzoek. Zo stelde Van Oudenhoven in 1969 vast dat van alle leerlingen van een BLO-school die deze sinds 1956 hadden verlaten, er $44 \%$ niet meer zwakzinnig genoemd konden worden. Zie Van Gennep 1977: 36-37.

${ }^{890}$ Zie Schuyt, Rapport over de oud-leerlingen der scholen voor lager onderwijs te 
Haarlem, die, de jaren 1920 tot en met 1924 de school verlieten uit de $5^{\circ}$, of een lagere klasse, Haarlem 1925, GAH NA 1521925 A 39 c.

Boek en Tijdschrift, TBO 1929: 205-207.

${ }^{892} \mathrm{Fr}$. Visser, TBO 1942: 40.

${ }^{893}$ Van Voorthuijsen, TBO 1929: 274-275.

${ }^{894}$ Zie Oosterhuis 2003: 12.

${ }^{895}$ Zie De Goei 2001.

${ }^{896}$ Scheerenberger 1983: 178

897 Zie onder andere Van Gennep 1980: 38-39.

${ }^{898}$ Onder andere was dat het geval met het onderzoek dat Fernald in 1919 publiceerde naar de patiënten die zijn inrichting tussen 1890 en 1914 hadden verlaten. Zie Van Gennep 1977: 28.

899 "Voor de maatschappij luidt de definitie (...) dat men volwassenen zwakzinnig moet noemen, wanneer zij ten gevolge van intelligentiedefecten zonder hulp van buiten niet in staat zijn in eigen levensonderhoud te voorzien." Van Voorthuijsen 1926: 328. 


\section{Lijst van gebruikte afkortingen}

AGO Arbeid voor Geestelijke Onvolwaardigen, de Amsterdamse vereniging die de werkinrichtingen voor zwakzinnigen aldaar exploiteerde, later ook een tehuis en een voogdij-instelling.

A\&O Vereeniging van Onderwijzers en Artsen, werkzaam aan Inrichtingen voor Onderwijs aan Achterlijke en Zenuwzwakke Kinderen, de algemene bond van onderwijzers aan het BLO.

AVO Arbeid Voor Onvolwaardigen, landelijke instelling voor arbeidsvoorziening, met name voor lichamelijke gehandicapten.

BLO Buitengewoon Lager Onderwijs.

B.O. Buitengewoon Onderwijs

B.O.L.S. Buitengewoon Onderwijs Lagere School

B.S. Buitengewone School of Scholen.

CBS Centraal Bureau voor de Statistiek.

Chrizona Christelijke Zorg en Nazorg, de Dordtse Christelijke nazorginstelling.

GAB Gewestelijk Arbeids Bureau, tijdens de bezetting door de Duitsers ingevoerd landelijk netwerk van arbeidsbureaus, opvolgers van de arbeidsbeurzen.

GG\&GD Gemeentelijke Geneeskundige- en Gezondsheids Dienst.

G.L.O. Gewoon Lager Onderwijs.

G.O. Gewoon Onderwijs.

K.Z. Krankzinnig, krankzinnige.

1.1. leerlingen

L.O. Lager Onderwijs

M.O.B. Medisch-Opvoedkundig Bureau.

NABO Nazorg Buitengewoon Onderwijs, de Zwolse nazorginstelling. Ook: Nazorg Almelo Buitengewoon Onderwijs.

NSB Nationaal-Socialistische Bond, de Nederlandse fascistische partij.

NVNBO Nederlandsche Vereeniging Nazorg Buitengewoon Onderwijs, de in 1931 opgerichte landelijke organisatie van betrokkenen bij de nazorg.

NVV Nederlands Verbond van Vakcentrales, de sociaal-democratische vakbond.

RKBLO Rooms-Katholiek Buitengewoon Lager Onderwijs, meestal in context van het Tijdschrift voor RKBLO.

Spr. Spreker.

TBO Tijdschrift voor Buitengewoon Onderwijs, uitgegeven door O\&A.

ZENBO Zorg en Nazorg Buitengewoon Onderwijs, de Enschedese nazorginstelling.

z.z. Zwakzinnig, zwakzinnige. 


\section{Bronnen}

\section{Archieven}

Kortheidshalve gebruik ik afkortingen om de verschillende archieven aan te duiden:
GAAm: Gemeentearchief Amsterdam
GAAr Gemeentearchief Arnhem
GAB: Gemeentearchief Breda
GADe: Gemeentearchief Delft
GADo: Gemeentearchief Dordrecht
GAG: Gemeentearchief 's-Gravenhage
GAH: Gemeentearchief Haarlem
GAR: Gemeentearchief Rotterdam
GAU: Gemeentearchief Utrecht
GAV: Gemeentearchief Vlaardingen
GAZ: Gemeentearchief Zwolle

\section{Landelijk:}

Nederlandsche Vereeniging Nazorg Buitengewoon Onderwijs, GAAm archief 1071 , doos 1931-1945, GAU archief 369, 20.

\section{Plaatselijk:}

\section{Amsterdam}

Nazorg, GAAm, archief nr. 5267 (GG\&GD) 1923-1945, de nummers: 1923: 4201, $4277 ; 1924: 384,3127,3601,3170,3299,3773 ; 1925: 108,387,631,897,1065$, $1146,1350,1543,1564,1913,2454,2559 ; 1926: 1094,1157 ; 1927: 2342 ; 1934$ : $368 ; 1935: 554,3387 ; 1936: 3619$.

A.G.O., archief AGO, Diemen, GAAm R. 154.13, Q 1080, R 1113, r 154.13, gemeenteblad Amsterdam 1923: eerste blad, 1478.

\section{Armhem}

Afdeling A.V.O./ Zorg voor Zwakzinnigen, GAAr 1.842-3, 11, 12, Br 18/16.

Stichting Arnhemsche Werkinrichting voor Zwakzinnigen, GAAr Br 26/32.

Breda

Stichting 'Nazorg', GAB 100-III-18.

Delft

Vereniging 'Nazorg', GADe Archief 102-1, 2, 3.

\section{Dordrecht}

Vereniging 'Zwakzinnigenzorg', GADo Archief 6-78, Archief 371-1, 2, 6, 7, 40, 41, 42, 43, 51, Archief 199-1, Bibliotheek 87-32, 179, Dordtsche Courant d.d. 4-1-1912.

's-Gravenhage

Vereniging 'Zorg voor het Achterlijke Kind', GAG, jaarverslagen 1907, 1907, 1926. 1935, bibliotheek P 3179.0

Buitengewoon Lager Onderwijs, GAG, jaarverslagen scholen voor buitengewoon onderwijs, 1905, 1910-1912, bibliotheek P 0671.0

Nazorg Buitengewoon Lager Onderwijs, GAG, Jaarverslag 1945, bibliotheek P 4591.0

\section{Haarlem}

Gemeentelijke dienst 'Nazorg', GAH N(ieuw) A(rchief) 152, 1924 B 41, A 39 i, 1925 A 39 c, 1926 A 39 c, 1927 A 39 c, 1928 A 39 c.

'Haarlemsche werkinrichting', GAH bibliotheek 43-001 $1930 \mathrm{KQ}$.

Maastricht

Stichting 'Zwakzinnigenzorg', Stichting Jan Baptist Maastricht. 
Rotterdam

Nazorg buitengewoon onderwijs, afd. Onderwijs, GAR 351.01b, dossiers 1929: 1190209, dossiers 1942: 1340-152.

Vereeniging 'Zorg en Nazorg voor Zwakzinnigen te Rotterdam-zuid', jaarverslagen 1937, 1939, GAR RB J 140.

Utrecht

Vereniging 'Zwakzinnigenzorg', GAU archief 369, 1, 2, 7, 8, 9, 19, 20, 21, 22, 23, 24 , $25,26,27$, SA VI 126 , SA VI 232-1.835.9, A VI 233 1.835.9.

Vlaardingen

Vereniging 'Zorg voor het Achterlijke kind', GAV 11 G 25, 8 C 55, 8 C 56, 8 C 58, 8 C 59,8 C 60,8 F 25 , VII 379.

Zwolle

'Nabo', GAZ VA 25.

\section{Primaire literatuur}

\subsection{Tijdschriften}

Voor dit onderzoek heb ik een groot aantal tijdschriften doorgenomen. Het aantal artikelen dat ik heb gelezen was dermate omvangrijk dat ik alleen die artikelen hier noem, die ik in de tekst heb aangehaald. Het Tijdschrift voor Zwakzinnigenzorg, PAIS, het Tijdschrift voor Buitengewoon Onderwijs en het Tijdschrift voor R.K. BLO heb ik geheel doorgenomen vanaf hun ontstaan tot aan de eerste nummers na de bevrijding. De andere tijdschriften die ik noem heb ik alleen doorgenomen omdat er in het bronnenmateriaal naar werd verwezen. Ik geef hier de artikelen per tijdschrift weer, op alfabetische volgorde.

\subsubsection{Jeugd en beroep}

Boer, P. de, De zwakzinnige en de school voor buitengewoon onderwijs, Jeugd en beroep, jaargang $1(1928) \mathrm{nr} .3,80-84$.

Boer, P. de, Karakter- en omgangsfouten van zwakzinnigen, Jeugd en beroep, jaargang $1(1928) \mathrm{nr} .6,188-192$.

Boer, P. de, De beoordeeling der zwakzinnigen bij het van schoolgaan, Jeugd en beroep, jaargang 1 (1928) nr. 7, 224-228.

Boer, P. de, De plaatsing van zwakzinnigen in werk, Jeugd en beroep, jaargang 1 (1928) nr. 9, 310-314.

Boer, P. de, Paedagogisch-psychologische waarnemingen op school, Jeugd en Beroep, jaargang 4 (1931) nr. 6, 179-183.

Boer, P. de, De zorg voor normalen en de zorg voor de zwakzinnigen, Jeugd en Beroep, jaargang 4 (1931) nr.7/8, 217-221.

De beroepskeuze van jeugdige onvolwaardigen, Jeugd en Beroep, jaargang 3 (1930), 254.

Det, E.J. van, Paedagogisch-psychologische waarneming op school, Jeugd en beroep, jaargang 4 (1931) nr. 4, 112-117.

Det, E.J. van, Antwoord aan P. de Boer, Jeugd en beroep, jaargang 4 (1931) nr.7/8, 221-225.

Det, E.J. van, Antwoord aan P. de Boer II, Jeugd en beroep, jaargang 4 (1931) nr. 9 , 279-282.

Koning, G., Centralisatie van de nazorg voor jeugdige onvolwaardigen, Jeugd en beroep, jaargang 3 (1930) 71-79.

\subsubsection{PAIS}

Supheert, N.J.M.H. en A. van Voorthuijsen, Een geval van psychopathie, PAIS, jaargang 1 (1917) nr. 7, 97-102.

Bruijn, T., Wie helpt me?, PAIS, jaargang 1 (1917 ) nr. 10, 148-149. 
Calliber, A.J., Eenige wenschen der Christelijke Vereeniging voor achterlijke en zenuwzwakke kinderen, PAIS, jaargang 3 (1919) nr. 3, 36-38.

Haan, C. de, D. Köhler. †, PAIS, jaargang 2 (1918) nr. 4, 49-50.

Herderschêe, D., De Zwakzinnigen en de Maatschappij, PAIS, jaargang 1 (1917) nr. 11, 161-163.

Herderschêe, D., Schoon schip onder de menschheid, PAIS, jaargang 1 (1917) nr. $12,189-190$.

Scheffener, W., Vereeniging van Onderwijzers en Artsen werkzaam aan Inrichtingen voor Onderwijs aan Achterijke en Zenuwzwakke kinderen, Jaarverslag 1916, PAIS, jaargang 1 (1917) nr. 7,108-109.

Voorthuijsen, A. van, Vakopleiding van psychopathen, PAIS, jaargang 1 (1917) nr. 10, 155-156.

Wepster, A.H.D., Buitengewone School te Dordrecht, PAIS, jaargang 1 (1917) nr.10, 159-159.

\subsubsection{Psychiatrische en Neurologische Bladen}

Deventer SzN, J. van, Het Wilhelminafonds, Psychiatrische en Neurologische Bladen, jaargang 1 (1897) 211-213.

Deventer SzN, .J. van, C.H. Sissingh en H. Postma, Eene algemeene psychopathenwet als preventieve maatregel tegen anti-sociale handelingen, Psychiatrische en Neurologische Bladen, jaargang 19 (1915) 484-491.

Dupont, A. e.a., Rapport der Commissie, over de verpleging van Idioten en Imbecillen, Psychiatrische en Neurologische Bladen, jaargang 6 (1902) 448-472.

Schuurmans Stekhoven, J.H., Huize Padua te Boekel, Psychiatrische en Neurologische Bladen, jaargang 19 (1915) 554-566.

\subsubsection{Tijdschrift van den Nederlandschen Werkloosheidsraad}

Detiger, W.F., De tewerkstelling van maatschappelijk mindergeschikten, Tijdschrift van den Nederlandschen Werkloosheidsraad, derde jaargang (1920) 389-463.

\subsubsection{Tijdschrift voor Buitengewoon Onderwijs}

Algemeene vergadering op 16 april 1927 in het gebouw van kunsten en wetenschappen te Utrecht, Tijdschrift voor Buitengewoon Onderwijs, jaargang 8 (1927) nr. 6, 128-140.

Berichten, Tijdschrift voor Buitengewoon Onderwijs, jaargang 3 (1922) nr. 10, 159 160 , jaargang $8(1927) \mathrm{nr} .1,19-20$, nr. 10, 212, jaargang $9(1928) \mathrm{nr} .3,75-76$, nr. 5, 132-136, nr. 7, 189-192, nr. 8, 220, nr. 10, 274-278, jaargang 10 (1929) nr. 3, 63-65, nr. 4, 121-125, nr. 5, 149-152, jaargang 11 (1930) nr. 3, 63-65, nr. 4, 86$89, \mathrm{nr}, 6,129-130, \mathrm{nr} .7,153-156, \mathrm{nr} .11,182-183$, jaargang $12(1931) \mathrm{nr} .3,56-$ 57 , nr. 5, 108-109, nr. 8, 176-178, jaargang 13 (1932), nr. 4, 93-94, nr. 5, $117-$ 118 , , jaargang 14 (1933) nr. 6, 126-128, jaargang 15 (1934) nr. 1, 19-22, nr. 2 , $44-46$, nr. 3, 65-70, nr. 5, 128-131, nr. 10, 239-242, jaargang 16 (1935) nr. 12 , 262-267, jaargang 17 (1936) nr. 10, 209-211, nr. 11, 234-236.

Berichten en Mededeelingen, Tijdschrift voor Buitengewoon Onderwijs, jaargang 1 (1920) nr. 1, 16.

Blanken, W., De christelijke medici en de sterilisatie, Tijdschrift voor Buitengewoon Onderwijs, jaargang 15 (1935) nr. 5, 118.

Blokpoel, W.P., De Nazorg, Tijdschrift voor Buitengewoon Onderwijs, jaargang 2 (1921) nr. 12, 179-187.

Boek en Tijdschrift, Tijdschrift voor Buitengewoon Onderwijs, jaargang 10 (1929) nr. 7, 205-207, jaargang $14(1933) \mathrm{nr} .11,237-240$, jaargang $15(1934) \mathrm{nr} .3,70-72$, nr. 7/8, 173-174, jaargang 18 (1937) nr. 11, 234-235.

Boer, P. de, De Nazorg bij het Buitengewoon Onderwijs, Tijdschrift voor Buitengewoon Onderwijs, jaargang 3 (1922) nr. 2, 18-20. 
Boer, P. de, De nazorg bij het buitengewoon onderwijs, Tijdschrift voor Buitengewoon Onderwijs, jaargang 4 (1923) nr. 11, 179-183.

Boer, P. de, Vakopleiding voor Zwakzinnigen I, Tijdschrift voor Buitengewoon Onderwijs, jaargang 13 (1932) nr. 10, 206-219.

Carstens, L.C., Uit het jaarverslag van den sociaal-paedagoog, Overijssel, Tijdschrift voor Buitengewoon Onderwijs, jaargang 21 (1940) nr. 2, 39-41.

Christ, G.A.E., Federatie B.L.O. in Nederland, Tijdschrift voor Buitengewoon Onderwijs, jaargang $22(1941) \mathrm{nr} .3,79$.

De tweede kursus voor voortgezette vakstudie voor het B.L.O., Tijdschrift voor Buitengewoon Onderwijs, jaargang $11(1930) \mathrm{nr} .2$, 34-38.

Douglas Turner, F., Zwakzinnigheid en sterilisatie, Tijdschrift voor Buitengewoon Onderwijs, jaargang 15 (1933) $\mathrm{nr} .5,112-118$.

Duitsland en de zorg voor minderwaardigen, Tijdschrift voor Buitengewoon Onderwijs, jaargang 14 (1933) nr. 8, 168.

Een kamp voor a-sociale debielen, Tijdschrift voor Buitengewoon Onderwijs, jaargang 25 (1944) $\mathrm{nr} .3,23$.

Edens, J.J. en D. Herderschêe, Het aantal zwakzinnigen, Tijdschrift voor Buitengewoon Onderwijs, jaargang $5(1924) \mathrm{nr} .8,130-137$.

Edens, J.J., en D. Herderschêe, Beschouwingen over zes jaar onderzoek voor het B.O. te Amsterdam, Tijdschrift voor Buitengewoon Onderwijs, jaargang 11 (1930) nr. $7,142-146$.

Een zeer belangrijke vergadering, Tijdschrift voor Buitengewoon Onderwijs, jaargang 13 (1932) nr. 5, 115-117.

Ginkel, C.D. van, Afdeelingsvergadering op 24 Nov. 1927 te Arnhem in 'Royal', Tijdschrift voor Buitengewoon Onderwijs, jaargang 9 (1928) nr. 1, 19-20.

Ginkel, C.D. van, Vergadering gehouden op 26 Jan. 1928 door de afdeeling Arnhem, in Hotel Riche om 7.30, Tijdschrift voor Buitengewoon Onderwijs, jaargang 9 (1928) nr. 3, 74.

Grootenboer, G.M., Naar aanleiding van: 'het onderwijs aan zwakzinnigen' door Dr. A. van Voorthuijsen, Tijdschrift voor Buitengewoon Onderwijs, jaargang 8 (1927) nr. 4, 73-75.

Haan. C. de, Bezuiniging?, Tijdschrift voor Buitengewoon Onderwijs, jaargang 15 (1934) nr. 5, 121-123.

Herderschêe, D., Betrekkelijk maatschappelijk ongeschikten, Tijdschrift voor Buitengewoon Onderwijs, jaargang 3 (1922) nr. 11, 170-171.

Herderschêe, D., J.J. Edens en P. de Boer, Zwakzinnigen, Tijdschrift voor Buitengewoon Onderwijs, jaargang 5 (1924) nr. 5, 77-78.

Herderschêe, D., De oorzaken der Zwakzinnigheid, Tijdschrift voor Buitengewoon Onderwijs, jaargang 6 (1925) nr. 9a, 141-159.

Herderschêe, Het vraagstuk der frustratie, Tijdschrift voor Buitengewoon Onderwijs, jaargang $11(1930) \mathrm{nr} .6,15-126$.

Herderschêe, D., Geestelijke Orthopaedie en preventieve geneeskunde, Tijdschrift voor Buitengewoon Onderwijs, jaargang 18 (1937) nr. 3, 48-50.

Hiemstra, S., Avondscholen voor de rijpere z.z. jeugd, Tijdschrift voor Buitengewoon Onderwijs, tweede jaargang (1921) nr. 9, 133-137, nr. 10, 143-150.

Hoofdbestuur, Tijdschrift voor Buitengewoon Onderwijs, jaargang 8 (1927) nr. 3, 6169 , jaargang $9(1928) \mathrm{nr} .3$, nr. 11, 300-303, jaargang $11(1930) \mathrm{nr} .6,126-129$, jaargang $16(1935) \mathrm{nr} .6,118-130$, jaargang 18 (1937) nr. 4, 89-90, jaargang 22 (1941) nr. 3, 76-78, nr. 5, 125-128, , jaargang 23 (1942) nr. 3, 40-45.

Houte, I.C. van, Toenemende criminaliteit, Tijdschrift voor Buitengewoon Onderwijs, jaargang 22 (1941) nr. 3, 59-62.

Jansen, G., De noodzakelijkheid van werkinrichtingen, Tijdschrift voor Buitengewoon Onderwijs, jaargang 15 (1934) nr. 12, 272-274. 
Koning, G., Het biezondere van het buitengewoon onderwijs, Tijdschrift voor Buitengwoon Onderwijs, jaargang 12 (1931) nr. 6, 128-131.

Leeflang, C., Zuidh. Ver. 'Het Groene Kruis', Commissie voor Geestelike Volksgezondheid, Tijdschrift voor Buitengewoon Onderwijs, jaargang 14 (1933) nr. 11, 229-231.

Leeflang, C., Kort verslag van de arbeid van de sociaal-paedagoog van het Groene Kruis (Commissie vor de geestelijke volksgezondheid), Tijdschrift voor Buitengewoon Onderwijs, jaargang 16 (1935) nr. 2, 30-31.

Leeflang, C., Jaarverslag der Commissie voor het Misdeelde Kind, uitgebracht door den sociaal-paedagoog der Zuid-Holl. vereniging 'Het Groene Kruis', Tijdschrift voor Buitengewoon Onderwijs, jaargang 17 (1936) nr. 3, 53-56.

Leeflang, C., Uit het jaarverslag van den sociaal-paedagoog, Zuid-Holland, Tijdschrift voor Buitengewoon Onderwijs, jaargang 21 (1940) $\mathrm{nr}$. 2, 38-39.

Opening van de vierde leergang voor B.O., Tijdschrift voor Buitengewoon Onderwijs, jaargang $12(1931) \mathrm{nr} .11,231-234$.

Opening werkinrichting voor zwakzinnige jongens te Apeldoorn, Tijdschrift voor Buitengewoon Onderwijs, jaargang 13 (1932) nr. 4, 94.

Ploeg, G.J. van der, Rapport inzake de nazorg voor zwakzinnigen en lichamelijk gebrekkigen. (Delft - april 1927), Tijdschrift voor Buitengewoon Onderwijs, jaargang 8 (1927) $\mathrm{nr} .12,245-248$.

Polderman, J., Sterilisatie, Tijdschrift voor Buitengewoon Onderwijs, jaargang 15 (1934) nr. 6, 142-144.

Roos, C.G. en H. Frantsen, Nazorg, Tijdschrift voor Buitengewoon Onderwijs, jaargang $6(1925) \mathrm{nr} .10,176$.

Schreuder, A.J., Werkverruiming en Arbeidsbemiddeling voor Onvolwaardige Arbeidskrachten, Tijdschrift voor Buitengewoon Onderwijs, jaargang 9 (1928) nr. 2, 32-38.

Schreuder, A.J., De biologische ondergrond der opvoeding, Tijdschrift voor Buitengewoon Onderwijs, jaargang 11 (1930) nr. 2, 22-29.

Schreuder, A.J., Hoe P.H. Schreuder bij het B.O. kwam, Tijdschrift voor Buitengewoon Onderwijs, jaargang 16 (1935) P.H. Schreudernummer, 33-34

Schreuder, P.G., Enige opmerkingen omtrent de regeling van de nazorg, Tijdschrift voor Buitengewoon Onderwijs, jaargang 10 (1929) nr. 9, 228-233.

Schreuder, P.G., Over het maatschappelijk doel en de taak onzer scholen, Tijdschrift voor Buitengewoon Onderwijs, jaargang 9 (1928) nr. 4, 86-97.

Schreuder, P.H., Zwakzinnigen, Tijdschrift voor Buitengewoon Onderwijs, vijfde jaargang (1924) nr. 4, 61-63.

Schuyt, E.P., Zorg en nazorg ten behoeve van geestelijk en lichamelijk misdeelden I, Tijdschrift voor Buitengewoon Onderwijs, jaargang 16 (1935) nr. 12, 255-259.

Uit het Réorganisatie-Rapport van de afd. Amsterdam van het B.v.N.O., Tijdschrift voor Buitengewoon Onderwijs, jaargang 2(1921) nr.7, 100-101.

V., W.A., Opening van de werkplaats voor geestelijk onvolwaardigen van de vereniging 'Zorg en Nazorg Buitengewoon Onderwijs' (Zenbo) te Enschede, Tijdschrift voor Buitengewoon Onderwijs, jaargang 21 (1940) nr. 2, 37-38.

Verslagen van sociaal-paedagogen, Tijdschrift voor Buitengewoon Onderwijs, jaargang $20(1939) \mathrm{nr} .7 / 8,162-163$.

Visser, C., Verkort rapport van de nazorg-en arbeidsonderwijscommissie, Tijdschrift voor Buitengewoon Onderwijs, jaargang 9 (1928) nr. 4, 97-101.

Visser, C., Arbeidsonderwijs en nazorg, Tijdschrift voor Buitengewoon Onderwijs, jaargang 9 (1928) nr. 9, 228-251.

Visser, Fr., onderzoek naar gehuwde zwakzinnigen in de gemeente Utrecht, Tijdschrift voor Buitengewoon Onderwijs, jaargang 17 (1936) nr. 5, 118-123.

Visser, Fr., Criminaliteit onder zwakzinnigen, Tijdschrift voor Buitengewoon Onderwijs, jaargang 19 (1938) nr. 12, 270-281. 
Visser, Fr. , Onze jongens (na een bezoek aan een werkinrichting), Tijdschrift voor Buitengewoon Onderwijs, jaargang 23 (1942) nr. 3, 40.

Voorthuijsen, A. van, Werkinrichtingen voor laagstaande zwakzinnigen, Tijdschrift voor Buitengewoon Onderwijs, jaargang 10 (1929) nr. 11, 270-284.

Voorthuijsen, A. van, Zwakzinnigenzorg in Engeland, Tijdschrift voor Buitengewoon Onderwijs, jaargang 11 (1930) nr. 5, 94-108.

Voorthuijsen, A. van, Geestelijke volksgezondheid, Tijdschrift voor Buitengewoon Onderwijs, jaargang 13 (1932) nr. 1, 2-16.

Voorthuijsen, A. van, Verslag van den toestand van het Buitengewoon Lager Onderwijs over het jaar 1931, Tijdschrift voor Buitengewoon Onderwijs, jaargang 15 (1934) nr. 4, 74-97.

Voorthuijsen, A. van, Verslag van den Inspecteur van het Buitengewoon Lager Onderwijs over het jaar 1934, Tijdschrift voor Buitengewoon Onderwijs, jaargang 16 (1935) nr. 10, 200-215, nr. 11, 224-239.

Voorthuijsen, A. van, Zwakzinnigenzorg in Denemarken, Tijdschrift voor Buitengewoon Onderwijs, jaargang 17 (1936) nr. 3, 57-63, nr. 4, 76-78

Voorthuijsen, A. van, Verslag van het Buitengewoon Lager Onderwijs over het jaar 1935, Tijdschrift voor Buitengewoon Onderwijs, jaargang 17 (1936) nr. 10, 190 202.

Voorthuijsen, A. van, Het buitengewoon onderwijs in federatief verband, Tijdschrift voor Buitengewoon Onderwijs, jaargang 21 (1940) nr. 12, 231.

Vos, G.J., De zwakke broeder, Tijdschrift voor Buitengewoon Onderwijs, jaargang 5 (1924) nr. 9, 141-144.

Waals, P. van der, 32ste jaarverslag der vereniging van onderwijzers en artsen, werkzaam bij het buitengewoon onderwijs - 1935-1936, Tijdschrift voor Buitengewoon Onderwijs, jaargang 17 (1936) nr. 4, 81-87.

Wal, E.C. van der, Zwakzinnigheid, Tijdschrift voor Buitengewoon Onderwijs, jaargang 20 (1939) nr. 4, 78-87, nr. 5, 105-107, nr. 11, 227-235, nr. 12, 243-247.

Wepster, A.H.D., Verslag over de Werkinrichting van Zwakzinnigen te Dordrecht (Gebouw Nieuwstraat) van 6 juni 1920 - 1 mei 1923, Tijdschrift voor Buitengewoon Onderwijs, jaargang 4 (1923) nr. 10, 169-172.

Wiersma, D., Psychopathen, zwakzinnigen en de school, Tijdschrift voor Buitengewoon Onderwijs, jaargang 21 (1940) nr. 4, 90-99.

\subsubsection{Tijdschrift voor Armwezen, Maatschappelijk Werk en Kinderbescherming}

Detiger, W.F., Een centraal handelsbureau voor A.V.O. werkplaatsen, Tijdschrift voor Armwezen, Maatschappelijke Hulp en Kinderbescherming, jaargang 9 (1930) nr. 200, 2389-2392.

Duys, R. v.d., Bijzondere bemiddeling voor niet-volwaardige arbeidskrachten te Amsterdam, Tijdschrift voor Armwezen, Maatschappelijke Hulp en Kinderbescherming, jaargang 6 (1927) nr. 143, 1500-1501, jaargang 7 (1928) nr. $145,1531$.

Erades, L., Achterlijke voogdijkinderen, Tijdschrift voor Armwezen, Maatschappelijke Hulp en Kinderbescherming, jaargang 15 (1936) nr. 347, 154-155.

\subsubsection{Tijdschrift voor R.K. BLO}

Benignus, Fr. M., Naar aanleiding van het artikel R.K. Scholen of Tehuizen voor Zwakz. Kinderen (blz. 18, 2e jg.), Tijdschrift voor R.K. Buitengewoon Lager Onderwijs, jaargang 2 (1926) nr. 4, 58-61.

Bondsverslagen 1940, jaarverslag van den 1en secretaris, Tijdschrift voor R.K. Buitengewoon Lager Onderwijs, jaargang 17 (1941) nr. 5, 133-137.

Calliber, A.J., Niet Scholen óf Tehuizen maar Scholen èn Tehuizen, Tijdschrift voor R.K. Buitengewoon Lager Onderwijs, jaargang 2 (1926) nr. 2, 88-89.

Chr. Buitengewoon Onderwijs, De Nazorg, Tijdschrift voor R.K. Buitengewoon Lager Onderwijs, jaargang 10 (1934) nr. 8, 260-261. 
Christ, G.A.E., Arbeidsklassen en Werkinrichting, Tijdschrift voor R.K. Buitengewoon Lager Onderwijs, jaargang 4 (1928) nr. 8, 172-176.

Christ, G.A.E., lets betreffende werkinrichtingen (voor oud-1.I. der zwakz. scholen), Tijdschrift voor R.K. Buitengewoon Lager Onderwijs, jaargang 13 (1937) nr. 1, 12 16.

E., H., R.K. Scholen of Tehuizen voor Zwakz. Kinderen, Tijdschrift voor R.K. Buitengewoon Lager Onderwijs, jaargang 2 (1926) 18-23.

E., H., Internaten, Tijdschrift voor R.K. Buitengewoon Lager Onderwijs, jaargang 2

Florianus, frater, Verslag $10^{\circ}$ Algemene Vergadering gehouden in Utrecht, in Hôtel $\mathrm{N}$. Brabant op 20-4-'33, Tijdschrift voor R.K. Buitengewoon Lager Onderwijs, negende jaargang (1933) nr. 6, 162-166.

Het onderwijs aan zwakzinnigen, Tijdschrift voor R.K. Buitengewoon Lager Onderwijs, jaargang 8 (1932) nr. 1, 28-34.

Jan Baptist, broeder, Nazorg. Tijdschrift voor R.K. Buitengewoon Lager Onderwijs, jaargang $1(1925) \mathrm{nr} .7,109-110, \mathrm{nr} .11,164-166, \mathrm{nr} .12,177-180$.

Jan Baptist, broeder, Onderwijsverslag 1926 der R.K. Buitengewone School te Maastricht, Tijdschrift voor R.K. Buitengewoon Lager Onderwijs, jaargang 3 (1927) nr. 6, 125-126.

Jan Baptist, broeder, De Nazorg voor de oud-leerlingen der scholen voor achterlijken, Tijdschrift voor R.K. Buitengewoon Lager Onderwijs, jaargang 10 (1934) nr. 5, 134-142.

Jan Baptist, broeder, Onze ledenvergadering 21 april te Utrecht, Tijdschrift voor R.K. Buitengewoon Lager Onderwijs, jaargang 14 (1938) nr. 6, 129-144.

Medeedelingen, Tijdschrift voor R.K. Buitengewoon Lager Onderwijs, jaargang 10 (1934) nr. 5, 155-156.

M. Ph., Fr., Protest tegen de Duitsche sterilisatiewet, Tijdschrift voor R.K. Buitengewoon Lager Onderwijs, jaargang 9 (1933) nr. 9, 246.

Peelmans, J., Het onderwijs aan zwakzinnigen, Tijdschrift voor R.K. Buitengewoon Lager Onderwijs, jaargang 3 (1927) nr. 2, 112-115.

Peelmans, J., Avondschool voor Zwakzinnigen, Tijdschrift voor R.K. Buitengewoon Lager Onderwijs, jaargang 3 (1928) nr. 10, 218-220.

R.K. Landelijke Nazorg-organisatie, Tijdschrift voor R.K. Buitengewoon Lager Onderwijs, jaargang 11 (1935) nr. 11, 292-293.

School en nazorg, Tijdschrift voor R.K. Buitengewoon Lager Onderwijs, jaargang 4 (1929) nr. 12, 279, 280.

Vereeniging voor Nazorg, Tijdschrift voor RKBLO, jaargang 7 (1931) nr. 1, 27.

Voorthuijsen, A. van, Nazorg voor zwakzinnigen te Amsterdam, Tijdschrift voor R.K. Buitengewoon Lager Onderwijs, jaargang 1 (1925) nr. 9, 129-132.

Voorthuijsen, A. van, Zwakzinnigenzorg. Tijdschrift voor R.K. Buitengewoon Lager Onderwijs, jaargang $3(1927) \mathrm{nr} .1,9-12$, nr. 2, 34-37, nr. 3, 48-51.

Werkinrichting voor zwakzinnigen in Rotterdam-Zuid, Tijdschrift voor R.K. Buitengewoon Lager Onderwijs, jaargang 9 (1933) nr. 6, 180-182.

Willemsen, Th.H.H., Nog eens dagschool of internaat, Tijdschrift voor R.K. Buitengewoon Lager Onderwijs, jaargang 2 (1926) nr. 7, 109-111.

Willemsen, Th. H.H., Hoe leidt het onderwijs voor achterlijke en zwakzinnigen op voor het maatschappelijk leven, Tijdschrift voor R.K. Buitengewoon Lager Onderwijs, jaargang 3 (1927) nr. 9, 175-187.

2.1.8 Tijdschrift voor sociale geneeskunde

Herderschêe, D., De Sociale Beteekenis der Acute Infectieziekten, Tijdschrift voor Sociale Geneeskunde, jaargang 11 (1933) nr. 2, 27-33.

Herderschêe, D., Bevolkingspolitiek en Eugenese, Tijdschrift voor Sociale Geneeskunde, jaargang 11 (1933) nr. 2, 34.

\subsubsection{Tijdschrift voor ziekenverpleging}


Schuurmans Stekhoven, J.H., Een Belangrijk Rapport, Tijdschrift voor Ziekenverpleging, jaargang 34 (1924) nr. 19, 663-669.

\subsubsection{Tijdschrift voor Zwakzinnigenzorg}

Obreen, M.H., Uit de practijk, Tijdschrift voor zwakzinnigenzorg, jaargang 4 (1916) 100-101.

Schuurmans Stekhoven, J. H., De studie der bevolking van Nederland, Tijdschrift voor zwakzinnigenzorg, jaargang 1 (1913) 6-20.

Visser, Fr., Latente kracht gemobiliseerd, Tijdschrift voor Zwakzinnigenzorg, jaargang 4 (1916) nummer 3, 68-72.

\subsection{Onderwijsverslagen}

Het ministerie van Binnenlandse zaken, later van Onderwijs, Kunsten en Wetenschap bracht jaarlijks een verslag uit van de toestand van het onderwijs aan de Tweede Kamer dat in de loop der jaren onder verschillende benamingen uitkwam. Deze verslagen heb ik doorgenomen vanaf 1911-1912 tot en met 1944-1946. In de noten verwijs ik kortheidshalve naar deze verslagen onder de naam onderwijsverslag.

Verslag van den staat der hooge, middelbare en lagere scholen in het koninkrijk der Nederlanden over ...., 's-Gravenhage (Ministerie van Binnenlandse Zaken) 19111912 tot en met 1915-1916.

Verslag van de staat van het onderwijs in het Koninkrijk der Nederlanden ...'sGravenhage (Ministerie van Binnenlandse zaken) 1916-1917 tot en met 19291930.

Het onderwijs in het jaar .... 's-Gravenhage (Ministerie van Onderwijs, Kunsten en Wetenschappen) 1930 tot en met 1946.

\subsection{Afzonderlijke publicaties}

Adriani, J.H.(1928), Maatschappelijk Hulpbetoon en de Onvolwaardige Arbeidskrachten (O.A.K.) De Particuliere en Kerkelijke Instellingen, Amsterdam: De Bussy.

Huize Angela, Arbeidsopvoeding bij Meisjes, in: Jacobs, H.J. e.a (red.) (1937), Het Buitengewoon Onderwijs in Nederland, 's-Gravenhage: HAGA.

Bartels, C.J. (1916), Voogdij voor Zwakzinnigen, 's Gravenhage: Van Stockem. Bemmelen, J.M. van (1933), Voor- en nadeelen van een wettelijke regeling der sterilisatie en castratie, Rotterdam: F, van Rossen.

Bemmelen, J.M. van, Het criminologisch aspect van zwakzinnigheid (Strafbare feiten bedreven door zwakzinnigen)in: J.M. van Bemmelen (red.) (1939), Misdadigheid en Wangedrag in verband met het Verschijnsel Zwakzinnigheid, 's-Gravenhage: Martinus Nijhoff.

Bemmelen, J.M. van, Praeventieve en strafmaatregelen bij zwakzinnigen (Algemeene en speciale praeventie, overzicht van heerschende opvattingen en desiderata), in: J.M. van Bemmelen (red.) (1939), Misdadigheid en Wangedrag in verband met het Verschijnsel Zwakzinnigheid, 's-Gravenhage: Martinus Nijhoff. Bierens de Haan, P. (1925), Maatschappelijke zorg voor psychisch invalieden (van psychiatrisch standpunt), , Haarlem: H.D. Tjeenk Willink \& Zoon.

Bloois, K. de, Psychopathen-Zorg in Nederland, in: Jacobs, H.J. e.a (red.) (1937), Het Buitengewoon Onderwijs in Nederland,'s-Gravenhage: HAGA. 
Bodaan, L.[1936], Veertig jaren onderwijs aan Geestelijk Misdeelden te Rotterdam, Rotterdam: z.u..

Boer, P. de, Nazorg voor het abnormale kind, in: Verslag van het eerste Nederlandsch paedagogisch congres (1926), Groningen: J.B. Wolters, 341-359.

Boer, P. de (1928), De zorg voor Achterlijken na hun Opleiding, Amsterdam: De Bussy.

Boer, P. de en R. Hoogland [1928], Het zwakzinnigenonderwijs en de nazorg. Rapport samengesteld door $P$. de Boer, ambtenaar voor de nazorg en $R$. Hoogland, sekretaris van het bureau voor kinderbescherming, Amsterdam: de Volharding.

Boer, P. de, Het behoud van de zwakzinnigen in het gezin, in: Schreuder, P.H., G.J. Vos en D. Herderschêe (red.) (1929), Gedenkboek omtrent zorg voor en onderwijs aan zwakzinnigen uitgegeven door de Vereeniging bij haar 25-jarig bestaan herdacht 30 maart 1929, 's-Gravenhage: Vereeniging van Onderwijzers en Artsen / HAGA, 140-146.

Boer, P. de, Nazorg voor Zwakzinnigen, Jacobs, H.J. e.a (red.) (1937), Het Buitengewoon Onderwijs in Nederland, Gedenkboek, aangeboden aan Dr. A. van Voorthuysen bij zijn aftreden als inspecteur van het Buitengewoon Lager Onderwijs, 's-Gravenhage: HAGA.

Boer, P. de, Het sociologisch aspect van zwakzinnigheid I, in: J.M. van Bemmelen (red) (1939), Misdadigheid en Wangedrag in verband met het Verschijnsel Zwakzinnigheid; lezingen gehouden voor het Leidse Criminologisch Instituut 1938-39; Strafrechtelijke en Criminologische Onderzoekingen X, 's-Gravenhage: Martinus Nijhoff.

Bonger, W.A. (1928), De Onvolwaardige Arbeidskrachten in haar Sociologische Beteekenis, Amsterdam: De Bussy.

Bosman, T. (1922), Zwakzinnige kinderen, Tilburg/Antwerpen: R.K. Jongensweeshuis.

Bouman, K.H., J. Gewin en D. Herderschêe, Rapport van de Commissie tot het bestudeeren van het vraagstuk der 'After Care' (Maatschappelijke Zorg), ingesteld door het bestuur der Vereeniging voor Spraakgebrekkige en Achterlijke Kinderen te Amsterdam, in: Kingma, T. e.a. (1984), Nederlandse Vereniging voor Sociaal Pedagogische Zorg 1932-1982, Jubileumboek ter gelegenheid van het 50-jarig bestaan, 's-Gravenhage: Nederlandse Vereniging voor Sociaal Pedagogische Zorg.

Broekhuizen, L., Provinciale Steun, in: Schreuder, P.H., G.J. Vos en D. Herderschêe (red.) (1929), Gedenkboek omtrent zorg voor en onderwijs aan zwakzinnigen uitgegeven door de Vereeniging bij haar 25-jarig bestaan herdacht 30 maart 1929, 's-Gravenhage: Vereeniging van Onderwijzers en Artsen / HAGA.

Burt, C. (1936), Geestelijke onvolwaardigheid, 's-Gravenhage: HAGA.

Calliber, A.J., Het Prot.Chr. Onderwijs aan Zwakzinnigen, in: Schreuder, P.H., G.J. Vos en D. Herderschêe (red.) (1929), Gedenkboek omtrent zorg voor en onderwijs aan zwakzinnigen uitgegeven door de Vereeniging bij haar 25-jarig bestaan herdacht 30 maart 1929, 's-Gravenhage: Vereeniging van Onderwijzers en Artsen / HAGA.

Calliber, A.J., Het Prot. Chr. Onderwijs aan Zwakzinnigen, Jacobs, H.J e.a (red.) (1937), Het Buitengewoon Onderwijs in Nederland, Gedenkboek, aangeboden aan Dr. A. van Voorthuysen bij zijn aftreden als inspecteur van het Buitengewoon Lager Onderwijs, 's-Gravenhage: HAGA.

Carp. E.A.D.E. (1936), Inleiding tot de psychologie der zwakzinnigheid, Rijswijk: Nieuwvoorde.

Carp, E.A.D.E., Het criminologische aspect van zwakzinnigheid (Het verband tusschen zwakzinnigheid en voorbeschiktheid tot dissociale resp. antisociale gedragingen), in: J.M. van Bemmelen (red.) (1939), Misdadigheid en Wangedrag 
in verband met het Verschijnsel Zwakzinnigheid; lezingen gehouden voor het Leidse Criminologisch Instituut 1938-39; Strafrechtelijke en Criminologische Onderzoekingen X, 's-Gravenhage: Martinus Nijhoff.

Centraal Bureau voor de Statistiek (1930), Statistiek van het Buitengewoon Lager Onderwijs 1929, 's-Gravenhage: CBS.

Centraal Bureau voor de Statistiek (1931), Statistiek van het Buitengewoon Lager Onderwijs 1930, 's-Gravenhage: CBS.

Centraal Bureau voor de Statistiek (1935), Intelligentieverhoudingen in Nederland, Groningen / Batavia: J.B. Wolters.

Centraal Bureau voor de Statistiek (1936), Statistiek van het Buitengewoon Lager Onderwijs 1931-1934, 's-Gravenhage: CBS.

Centraal Bureau voor de Statistiek (1939), Statistiek van het Buitengewoon Lager Onderwijs 1935-1938, 's-Gravenhage: CBS.

Centraal Bureau voor de statistiek (1949), Statistiek van het buitengewoon lager onderwijs 1939-1947, 's-Gravenhage: Staatsdrukkerij- en uitgeverijbedrijf.

Centrale Vereeniging ter Behartiging van de Maatschappelijke Belangen van Zenuwen Zielszieken (1928), Amsterdam, Centrale Vereeniging ter Behartiging van de Maatschappelijke Belangen van Zenuw- en Zielszieken.

Christ, G.A.E., De Ontwikkeling van het R.K. Zwakzinnigenonderwijs, in: Schreuder, P.H., G.J. Vos en D. Herderschêe (red.) (1929), Gedenkboek omtrent zorg voor en onderwijs aan zwakzinnigen uitgegeven door de Vereeniging bij haar 25-jarig bestaan herdacht 30 maart 1929, 's-Gravenhage: Vereeniging van Onderwijzers en Artsen / HAGA.

Christ, G.A.E., Het R.K. Buitengewoon Onderwijs aan Zwakzinnigen, Jacobs, H.J e.a (red.) (1937), Het Buitengewoon Onderwijs in Nederland, Gedenkboek, aangeboden aan Dr. A. van Voorthuysen bij zijn aftreden als inspecteur van het Buitengewoon Lager Onderwijs, 's-Gravenhage: HAGA.

Commissie benoemd door Burgemeester en Wethouders der Gemeente Haarlem, ingevolge Raadsbesluit 12 Juli 1922 [1924], Rapport over Nazorg voor Zwakzinnigen, Haarlem: [gemeente Haarlem].

Detiger, W.F. e.a. [1918], De Amsterdamsche Arbeidsbeurs, haar geschiedenis, haar huidige werkwijze en haar toekomst, Amsterdam: Stadsdrukkerij.

Detiger, W.F. (1922), De vraagstukken der arbeidsmarkt, Alphen a.d. Rijn: N. Samsom.

Detiger, W.F. (1928), De Werkloosheid en de Taak der Arbeidsbeurzen ten aanzien van de Onvolwaardige Arbeidskrachten, Amsterdam: De Bussy.

Detiger, W.F., Arbeidszorg voor onvolwaardigen, in: Everts, J. (red.) (1933), Gids voor Maatschappelijk Hulpbetoon in Nederland, Zeist: J. Ploegsma.

De zorg voor de lichamelijk of geestelijk gebrekkigen, Gids van Instellingen in Nederland samengesteld op verzoek van de A.V.O. door den armenraad te Amsterdam (1928), Amsterdam: z.u..

Domisse, F. (1937), Het licht op den drempel, Rotterdam: W.L. \& J. Brusse.

Edens, J.J., De wettelijke regeling van het Onderwijs aan Zwakzinnigen, in:

Schreuder, P.H., G.J. Vos en D. Herderschêe (red.) (1929), Gedenkboek omtrent zorg voor en onderwijs aan zwakzinnigen uitgegeven door de Vereeniging bij haar 25-jarig bestaan herdacht 30 maart 1929, 's-Gravenhage: Vereeniging van Onderwijzers en Artsen / HAGA.

Egbertus, F.M., Arbeidsopvoeding op de school voor B.L.O., Jacobs, H.J. (red.) (1937), Het Buitengewoon Onderwijs in Nederland, Gedenkboek, aangeboden aan Dr. A. van Voorthuysen bij zijn aftreden als inspecteur van het Buitengewoon Lager Onderwijs, 's-Gravenhage: HAGA).

Everts, J. [1928], Uitvoerende taak van de Overheid en het Particulier Initiatief ten Opzichte van de Onvolwaardige Arbeidskrachten, Amsterdam: De Bussy. 
Everts, J. (red.) (1933), Gids voor Maatschappelijk Hulpbetoon in Nederland, Zeist: J. Ploegsma.

Fortanier, A.H.(1928), Maatschappelijk Hulpbetoon en Onvolwaardige Arbeidskrachten door de Overheid, Amsterdam: De Bussy.

Fortanier, A.H. (1928), Onvolwaardige Arbeidskrachten onder de Werkloozen en Oudere Arbeiders, Amsterdam: De Bussy.

Fortanier, A.H., De persoonlijkheid van den zwakzinnige (Driftleven), J.M. van Bemmelen (red) (1939), Misdadigheid en Wangedrag in verband met het Verschijnsel Zwakzinnigheid; lezingen gehouden voor het Leidse Criminologisch Instituut 1938-39; Strafrechtelijke en Criminologische Onderzoekingen X, 'sGravenhage: Martinus Nijhoff.

Frantsen, H.(1929), Werkinrichtingen, Schreuder, P.H., G.J. Vos en D. Herderschêe (red.), Gedenkboek omtrent zorg voor en onderwijs aan zwakzinnigen uitgegeven door de Vereeniging bij haar 25-jarig bestaan herdacht 30 maart 1929, 'sGravenhage: Vereeniging van Onderwijzers en Artsen / HAGA.

Frantsen, H. (1930), Lezing gehouden op 22 mei 1930 voor de Inspectie-vergadering Brielle, te R'dam in de Diergaarde, z.p.: z.u..

Frets, G.P.(1933), Sterilisatie, Rotterdam: F. van Rossen.

Fuldauer, $\mathrm{Ph}$., Joodsche Inrichtingen voor Buitengewoon Onderwijs, Jacobs, H.J. e.a (red.) (1937), Het Buitengewoon Onderwijs in Nederland, Gedenkboek, aangeboden aan Dr. A. van Voorthuysen bij zijn aftreden als inspecteur van het Buitengewoon Lager Onderwijs, 's-Gravenhage: HAGA.

Gedenkboek omtrent zorg voor en onderwijs aan zwakzinnigen uitgegeven door de Vereeniging bij haar 25-jarig bestaan herdacht 30 maart 1929 (1929), 'sGravenhage: Vereeniging van Onderwijzers en Artsen / HAGA.

Gids betreffende de Geestelijke Volksgezondheid (psychische hygiëne) in Nederland (1936), Amsterdam: F. van Rossen.

Graaf, A. de (1928), Uitvoerende taak van het Particulier Initiatief en de Overheid, Amsterdam: De Bussy.

Gregor, A. en E. Voigtländer (1922), Charakterstruktur verwahrloster Kinder und Jugendlicher, z.p.: Johann Ambrosius Barth.

Greve, de e.a. (1901), Rapport der Commissie, aangewezen door het Bestuur van Volksonderwijs "s-Gravenhage II" tot het instellen van een onderzoek naar het onderwijs aan achterlijke kinderen te 's-Gravenhage, 's-Gravenhage: bestuur der Afdeeling II van de Vereeniging 'Volksonderwijs'.

Grewel, F. en J. Koekebakker, Praeventieve en strafmaatregelen voor jeugdige zwakzinnigen, J.M. van Bemmelen (red) (1939), Misdadigheid en Wangedrag in verband met het Verschijnsel Zwakzinnigheid; lezingen gehouden voor het Leidse Criminologisch Instituut 1938-39; Strafrechtelijke en Criminologische Onderzoekingen X, 's-Gravenhage: Martinus Nijhoff.

Heeroma, K.H. (1946), Eenige gegevens betreffende de leerlingen van de scholen voor Buiten-gewoon Onderwijs voor Zwakzinnigen te Groningen, Groningen/Batavia: J.B. Wolters.

Herderschêe, D. (1928), De Opleiding der Achterlijken, Amsterdam: De Bussy. Herderschêe, D. (1934), Achterlijke kinderen, 's Gravenhage: HAGA.

Herderschêe, D. (1947), De geestelijke volksgezondheid en het vraagstuk der zwakzinnigheid, Amsterdam: Noord-Hollandsche Uitgevers Maatschappij.

Herwerden, M.A. van (1929), Erfelijkheid bij den mensch en eugenetiek, z.p.: Wereldbibliotheek..

Heijermans, L. (1929), Gemeentelijke Gezondheidszorg in Nederland, Amsterdam: Ontwikkeling.

Heijermans, L., e.a. [1930], RAPPORT der Commissie van Onderzoek inzake de verpleging en verzorging van zenuwzieken, krankzinnigen en maatschappelijk 
ongeschikten vanwege de gemeente Amsterdam, Amsterdam: Stadsdrukkerij Amsterdam.

Hoe zwakzinnige en achterlijke kinderen worden opgevoed en onderwezen [1940],

's-Hertogenbosch: R.K. Charitatieve Vereeniging voor Geestelijke

Volksgezondheid.

Horst, L. van der, E.A.D.E. Carp en A. Querido [1940], De beteekenis der geestelijke hygiène voor de onvolwaardigenzorg, Den Bosch: R. K. Charitatieve Vereeniging voor Geestelijke Volksgezondheid.

Houte, I. C. van, Beschermingsmaatregelen bij zwakzinnigen (Behandeling van het zwakzinnigenvraagstuk van opvoedkundige zijde), J.M. van Bemmelen (red) (1939), Misdadigheid en Wangedrag in verband met het Verschijnsel Zwakzinnigheid; lezingen gehouden voor het Leidse Criminologisch Instituut 1938-39; Strafrechtelijke en Criminologische Onderzoekingen X, 's-Gravenhage: Martinus Nijhoff.

Immig, C. e.a. (1913), Het onderwijs en ambachtsonderwijs aan zwakzinnige kinderen, rapport, uitgebracht door de commissie ter behartiging der belangen van leerlingen en oud-leerlingen der buitengewone scholen voor lager onderwijs te Rotterdam, Rotterdam: Corns. Immig \& zoon.

Inhoven, W., Der Anschluss der Hilfsschule an das wirtschaftliche Leben, Verslag van het Tweede Nederlandsch Paedagogisch Congres (1932), Groningen: J.B.Wolters, 758-770.

Jacobs, H.J., Het Arbeidsonderwijs (voor jongens), Schreuder, P.H., G.J. Vos en D. Herderschêe (red.) (1929), Gedenkboek omtrent zorg voor en onderwijs aan zwakzinnigen uitgegeven door de Vereeniging bij haar 25-jarig bestaan herdacht 30 maart 1929, 's-Gravenhage: Vereeniging van Onderwijzers en Artsen / HAGA. Jacobs, H.J., Het Zwakzinnigenonderwijs in Nederland, H.J. Jacobs e.a. (red.) (1937), Het Buitengewoon Onderwijs in Nederland, gedenkboek, aangeboden aan Dr. A. van Voorthuysen bij zijn aftreden als inspecteur van het Buitengewoon Lager Onderwijs, 's-Gravenhage: HAGA.

Jacobs, H.J., Het Openbaar Onderwijs aan Zwakzinnigen, Jacobs, H.J.e.a (red.) (1937), Het Buitengewoon Onderwijs in Nederland, Gedenkboek, aangeboden aan Dr. A. van Voorthuysen bij zijn aftreden als inspecteur van het Buitengewoon Lager Onderwijs, 's-Gravenhage: HAGA.

Jan Baptist, broeder e.a. (1943), Bond ter bevordering van het R.K. Buitengewoon Lager Onderwijs. Jaarverslag over 1942, z.p.: Bond ter bevordering van het R.K. Buitengewoon Lager Onderwijs.

Josephus Jitta, N.M. e.a. (1938), Verslag Staatscommissie inzake onvolwaardige arbeidskrachten, ingesteld bij kon. Besl. Van 12 april 1929, 's-Gravenhage: Algemeene Landsdrukkerij.

Kastein, G, Het sociologisch aspect van Zwakzinnigheid II, J.M. van Bemmelen (red) (1939), Misdadigheid en Wangedrag in verband met het Verschijnsel Zwakzinnigheid; lezingen gehouden voor het Leidse Criminologisch Instituut 1938-39; Strafrechtelijke en Criminologische Onderzoekingen X, 's-Gravenhage: Martinus Nijhoff.

Kindermann, H. (red.) (1929), Handelingen van het A. V.O. -Congres Amsterdam 8-12 october 1928, Amsterdam: M.J. Portielje.

Klootsema, J. (1896), Paedagogiek en alcoholisme; Eene ziel- zede-en onderwijskundige studie; naar aanleiding van het artikel in Vragen des Tijds jaargang 22, no. 6, door Mr. H. Goeman Borgesius, Groningen: Erven B. Van de Kamo.

Klootsema, J. (1904), Misdeelde Kinderen, inleiding tot de paedagogische pathologie en therapie, Groningen: J.B. Wolters.

Koenen, J.H.M. (1933), Zwakzinnigheid bij kinderen: haar beteekenis in paedagogische en sociaal opzicht, Waalwijk: Tielen). 
Kohlbrugge, J.H.F. (1926), Practische Sociologie deel III: de zorg voor het abnormale kind, Groningen / Den Haag: J.B. Wolters' U.M..

Koning, G. e.a. (1931), Nazorg, verslag over de nazorg voor de ontslagen leerlingen der openbare en bijzondere scholen voor buitengewoon lager onderwijs en voor de lichamelijk-gebrekkige rijpere jeugd, uitgebracht door de commissie, benoemd door burgemeester en wethouders van 's-Gravenhage, bij besluit van den 24 sten april 1928, no 96050, Groningen/'s-Gravenhage: Wolters.

Kortenhorst, C.T. (1931), Wat wil de R.K. Charitatieve Vereeniging voor Geestelijke Volksgezondheid, ['s-Hertogenbosch]: R.K. Charitatieve Vereeniging voor Geestelijke Volksgezondheid.

Kortenhorst, C.T.(z.j.), Zwakzinnigenzorg en Geestelijke Volksgezondheid, z.p.: z.u..

Leeflang, C., Vereenigingsleven, Schreuder, P.H., G.J. Vos en D. Herderschêe (red.) (1929), Gedenkboek omtrent zorg voor en onderwijs aan zwakzinnigen uitgegeven door de Vereeniging bij haar 25-jarig bestaan herdacht 30 maart 1929, 's-Gravenhage: Vereeniging van Onderwijzers en Artsen / HAGA.

Liefland, W.A. van (1940), De school voor het afwijkende kind, 's-Gravenhage: HAGA.

Linthorst, P., Kolonieverpleging, Schreuder, P.H., G.J. Vos en D. Herderschêe (red.) (1929), Gedenkboek omtrent zorg voor en onderwijs aan zwakzinnigen uitgegeven door de Vereeniging bij haar 25-jarig bestaan herdacht 30 maart 1929, 's-Gravenhage: Vereeniging van Onderwijzers en Artsen / HAGA.

Marx, K. en F. Engels (1979), Het Communistisch Manifest, Amsterdam: Pegasus.

Meinema, T. (1923), Gezinsverpleging van geesteszieken, Baarn: Hollandia.

Meijers, F.S. (1926), De Arbeidsinrichtingen te Basel en te Frankfurt a/M. vergeleken met die ten onzent, z.p.: Centrale Vereeniging ter Behartiging van de Maatschappelijke Belangen van Zenuw- en Zielszieken.

Meijers, F.S. (1928), Consultatiebureaux voor Geesteszieken, Amsterdam: De Bussy.

Meijers, F.S. (1931), De geestelijke hygiëne en hare beteekenis voor onze samenleving; Psychiatrisch Juridisch Gezelschap, verslag van bijeenkomst op 13 december 1930 te Amsterdam; no. 1, Amsterdam: Van Rossen.

Meijers, F.S. (1939), De Voor-en Nazorg van Geestelijk Hulpbehoevenden, Amsterdam: Centrale Vereeniging ter Behartiging der Maatschappelijke Belangen van Zenuw- en Zielszieken.

Nuyl, Th. W. te (1928), Plaatselijk nazorg-werk voor onvolwaardige arbeidskrachten, Deventer: Deventer Nazorg-comité 'De Hoop'.

Overwater, J., J. Lammerts van Bueren en F.S. Meijers (1926), Voogdijvoorziening voor zieke, zwakke, gebrekkige en zwakzinnige kinderen, Hoenderloo: Nederlandschen Bond tot Kinderbescherming.

Pameyer, J.H. (1928), Plaatsing in de Maatschappij van Geestelijk Onvolwaardigen, Amsterdam: De Bussy.

Ploeg, G. J. van der (z.j.), Over onderwijs aan eenvoudigen van geest, 'sGravenhage: Vereniging van Onderwijzers en Artsen werkzaam bij het Buitengewoon Onderwijs.

Potters, T.J. (1949), Rapport over de werkzaamheden en plannen van de "Stichting Nazorg", Breda: z.u..

Querido, A. (1933), Het Zeeburgerdorp, een sociaal-psychiatrische studie, Leiden I Amsterdam: H.E. Stenfert Kroese.

Querido, A. (1935), De omgang met geesteszieken in het gezin, Amsterdam: De Arbeiderspers.

Querido, A. (1937), Het onmaatschappelijke gezin, z.p.: Nederlandsche Vereeniging voor Geestelijke Volksgezondheid.

Querido, A. (1948), De nazorg voor het Buitengewoon Onderwijs te Amsterdam, plaats, taak en werkwijze, Amsterdam: GG\&GD / Stichting AGO. 
Rütte, J.L.C.G.A. le (1928), Arbeidsgeschiktheid van de Psychisch Onvolwaardige Arbeidskracht, Amsterdam: De Bussy.

Rütte, J.L.C.G.A. le (1928), Arbeidstherapie in Internaten, Amsterdam: De Bussy.

Schaik, C.H. van, Het huishoudonderwijs, Schreuder, P.H., G.J. Vos en D.

Herderschêe (red.) (1929), Gedenkboek omtrent zorg voor en onderwijs aan

zwakzinnigen uitgegeven door de Vereeniging bij haar 25-jarig bestaan herdacht

30 maart 1929, 's-Gravenhage: Vereeniging van Onderwijzers en Artsen / HAGA.

Scholz, L. en A. Gregor (1922), Anomale Kinder, Berlijn: S. Karger.

Schreuder, A.J. [1919], De wettelike regeling van het buitengewoon onderwijs,

Baarn: E.J. Bosch JBZN.

Schreuder, P.G. (1931), De wettelike regeling van het buitengewoon onderwijs,

Arnhem: G.W. van der Wiel en Co.

Schreuder, P.G., Verhoging der maatschappelike Bruikbaarheid als Doel der School, Verslag van het Tweede Nederlandsch Paedagogisch Congres (1932),

Groningen: J.B.Wolters, 770-797.

Schreuder, P.H., Voortgezette Vakstudie, Schreuder, P.H., G.J. Vos en D.

Herderschêe (red.) (1929), Gedenkboek omtrent zorg voor en onderwijs aan

zwakzinnigen uitgegeven door de Vereeniging bij haar 25-jarig bestaan herdacht 30 maart 1929, 's-Gravenhage: Vereeniging van Onderwijzers en Artsen / HAGA.

Schreuder, P.H., Nieuwe stromingen bij het onderwijs aan zwakzinnigen, Verslag van het Tweede Nederlandsch Paedagogisch Congres (1931), Groningen:

J.B.Wolters, 741-754.

Schreuder, P.H., De eerste inspecteur van het Buitengewoon Lager Onderwijs 1 Januari 1921- 1 Maart 1937, Jacobs, H.J. e.a (red.) (1937), Het Buitengewoon Onderwijs in Nederland, Gedenkboek, aangeboden aan Dr. A. van Voorthuysen bij zijn aftreden als inspecteur van het Buitengewoon Lager Onderwijs, 'sGravenhage: HAGA.

Schuyt, E.P. [1946], Nazorg voor leerlingen der B.L.O. Scholen, Rotterdam: Centrale Commissie Kinderbescherming.

Schuyt, H.A., Avondonderwijs en Avondverzorging, Schreuder, P.H., G.J. Vos en D. Herderschêe (red.) (1929), Gedenkboek omtrent zorg voor en onderwijs aan zwakzinnigen uitgegeven door de Vereeniging bij haar 25-jarig bestaan herdacht 30 maart 1929, 's-Gravenhage: Vereeniging van Onderwijzers en Artsen / HAGA.

Slot, W.L., Volwassen Zwakzinnigen, Schreuder, P.H., G.J. Vos en D. Herderschêe (red.) (1929), Gedenkboek omtrent zorg voor en onderwijs aan zwakzinnigen uitgegeven door de Vereeniging bij haar 25-jarig bestaan herdacht 30 maart 1929, 's-Gravenhage: Vereeniging van Onderwijzers en Artsen / HAGA.

Snijders Oomen, A.W.M. (z.j.), Het afwijkende kind en het huisgezin, 's Hertogenbosch: R.K. Charitatieve Vereeniging voor Geestelijke Volksgezondheid.

Spek, P.A.F. van der (1942), De psychopathenschool, 's-Hertogenbosch: R.K. Charitatieve Vereeniging voor Geestelijke Volksgezondheid.

Spek, P.A.F. van der (1943), Over de gezinsvoogdij van abnormale kinderen, 'sHertogenbosch: R.K. Charitatieve Vereeniging voor Geestelijke Volksgezondheid.

Swildens, J.J. [1918], Nazorg (after-care), z.p.: z.u..

Verdenius - de Jong Saakes, E.J. (1947), Wangedrag van debiele minderjarigen, 'sGravenhage: D.A. Daamen.

Vereeniging 'Zorg voor het achterlijke Kind' te Rotterdam 1914-1929 [1929], Rotterdam: z.u..

Vereeniging 'Zorg voor het achterlijke Kind' te Rotterdam 1914-1939 [1939], Rotterdam: z.u..

Verslagboek van het Roomsch-Katholiek nationaal jeugdcongres met tentoonstelling en den nationalen gezellendag gehouden te 's-Gravenhage 30 juli - 6 augustus 1922 (1923), 's-Hertogenbosch: L.C.G. Malmberg. 
Verslag van de Achttiende Algemene Vergadering, Geschriften van de Nederlandsche Vereeniging voor Armenzorg en Weldadigheid te Amsterdam, vol. XXXIX (1925), Haarlem: H.D. Tjeenk Willink \& Zoon.

Visscher, J.A., Maatschappelijke zorg voor geestelijk invaliden, Geschriften van de Nederlandsche Vereeniging voor Armenzorg en Weldadigheid te Amsterdam, vol. XXXVIII (1925), Haarlem: H.D. Tjeenk Willink \& Zoon.

Voorthuijsen, A. van (1925), Nazorg voor zwakzinnigen, overdruk uit het Tijdschrift voor Sociale Geneeskunde, z.p.: z.u..

Voorthuijsen, A. van, De organisatie van het onderwijs aan zwakzinnigen voor ons geheele land, Verslag van het eerste Nederlandsch paedagogisch congres (1926), Groningen: J.B. Wolters, 325-341.

Voorthuijsen, A. van (1928), Het eigen Karakter der Zwakzinnigenzorg, Amsterdam: De Bussy.

Voorthuijsen, A. van, De organisatorische ontwikkeling van het onderwijs aan zwakzinnigen in de laatste 25 jaren, Schreuder, P.H., G.J. Vos en D. Herderschêe (red.) (1929), Gedenkboek omtrent zorg voor en onderwijs aan zwakzinnigen uitgegeven door de Vereeniging bij haar 25-jarig bestaan herdacht 30 maart 1929, 's-Gravenhage: Vereeniging van Onderwijzers en Artsen / HAGA. Voorthuijsen, A. van, Zorg voor en onderwijs aan zwakzinnigen, Everts, J. (red.) (1933), Gids voor Maatschappelijk Hulpbetoon in Nederland, Zeist: J. Ploegsma. Voorthuijsen, A. van, Zorg voor en Onderwijs aan Zwakzinnigen, Vijf en twintig jaar Buitengewoon Onderwijs te Haarlem, 1909 - 1 april - 1934 (1934), Haarlem: afd. 'Haarlem en O.' van de Vereeniging van Onderwijzers en Artsen, werkzaam bij het Buitengewoon Onderwijs.

Voorthuijsen, A. van, Zorg voor onvolwaardigen in het algemeen, Instituut voor Bestuurswetenschappen der Vereeniging van Nederlandsche Gemeenten, Het Buitengewoon Lager Onderwijs (1940), 's-Gravenhage: Vereeniging van Nederlandsche Gemeenten, 1-14.

Voorthuijsen, A. van (1941), RAPPORT over een onderzoek naar het milieu der leerlingen van de Haagse scholen voor Buitengewoon Onderwijs, uitgebracht aan den secretaris-generaal van het departement van Opvoeding, Wetenschap en Cultuurbescherming, 's-Gravenhage: Algemeene Landsdrukkerij.

Vos. G.J., Karaktervorming en Zwakzinnigheid, Verslag van het eerste Nederlandsch paedagogisch congres (1926), Groningen: J.B. Wolters, 368-378.

Vos, G.J., lets over de ontwikkeling van het onderwijs en de opvoeding in de zwakzinnigenschool, Schreuder, P.H., G.J. Vos en D. Herderschêe (red.)(1929), Gedenkboek omtrent zorg voor en onderwijs aan zwakzinnigen uitgegeven door de Vereeniging bij haar 25-jarig bestaan herdacht 30 maart 1929, 's-Gravenhage: Vereeniging van Onderwijzers en Artsen / HAGA.

Waardenburg, P.J., Verantwoordelijkheid en Erfelijkheid, Verslag van het Tweede Nederlandsch Paedagogisch Congres (1931), Groningen: J.B. Wolters, 44-64.

Wart, W.F.H. van de (1921), Buitengewoon Lager Onderwijs - onderwijs aan zwakzinnigen, Groningen: P. Noordhoff.

Wepster, A.H.D. (1928), Arbeidstherapie in Externaten, Amsterdam: De Bussy. Wepster, A.H.D., Leiding na het verlaten der school (Nazorg), Schreuder, P.H., G.J. Vos en D. Herderschêe (red.) (1929), Gedenkboek omtrent zorg voor en onderwijs aan zwakzinnigen uitgegeven door de Vereeniging bij haar 25-jarig bestaan herdacht 30 maart 1929, 's-Gravenhage: Vereeniging van Onderwijzers en Artsen I HAGA.

Wenschen inzake nazorg voor Zwakzinnigen [1925], 's-Gravenhage: Vereeniging van Onderwijzers en Artsen, werkzaam aan inrichtingen voor onderwijs aan achterlijke en zenuwzwakke kinderen afdeling 's-Gravenhage:

Westerbeek van Eerten, B.J. (1920), Eugenetiek, historisch critisch overzicht, Varsseveld: A.A. van Deutekom. 
Wiersma, D., De persoonlijkheid van den Zwakzinnige (De Intelligentie), J.M. van Bemmelen (red) (1939), Misdadigheid en Wangedrag in verband met het verschijnsel Zwakzinnigheid; lezingen gehouden voor het Leidse Criminologisch Instituut 1938-39; Strafrechtelijke en Criminologische Onderzoekingen X, 'sGravenhage: Martinus Nijhoff.

Winter, H. de, Handenarbeid op de school voor buitengewoon L.O., Schreuder, P.H., G.J. Vos en D. Herderschêe (red.) (1929), Gedenkboek omtrent zorg voor en onderwijs aan zwakzinnigen uitgegeven door de Vereeniging bij haar 25-jarig bestaan herdacht 30 maart 1929, 's-Gravenhage: Vereeniging van Onderwijzers en Artsen / HAGA.

Wijhe, M. van (1902), Achterlijke Kinderen, Amsterdam: Maatschappij tot Nut van 't Algemeen.

Wijnveldt, J., Maatschappelijke zorg voor geestelijk invaliden, Geschriften van de Nederlandsche Vereeniging voor Armenzorg en Weldadigheid te Amsterdam, vol. XXXVIII (1925), Haarlem: H.D. Tjeenk Willink \& Zoon.

Ziehen, T. (1917), Die Geisteskrankheiden des Kindesalters, einschliesslich des Schwachsinns und der psychopathischen Konstitutionen, Berlijn: Reuther \& Reichard.

\section{Secundaire literatuur}

Akkermans, C., Gemeentelijke zorg voor geestelijke gezondheid, de sociaalpsychiatrische dienst van de Amsterdamse GG\&GD, 1933-1988, Maandblad Geestelijke Volksgezondheid, jaargang 56 (2001) nr. 7/8, 644-658.

Bartels, J.A.C. e.a. (red.) (1980), 75 jaar kinderwetten 1904-1980, Zwolle: Tjeenk Willink).

Barnouw, D. (1994), Rost van Tonningen, Fout tot het bittere eind, Zutphen: Walburg Pers.

Beishuizen, J. en E. Werkman (1980), De magere jaren, Nederland in de crisistijd 1929-1939, Alphen aan den Rijn, A.W. Sijthoff.

Bervoets, L., Een 'voorbeeldige' pionier, Marie Muller-Lulofs (1854-1954), B.Waaldijk, J. van der Stel en G. van der Laan (red.) (1999), Honderd jaar sociale arbeid,

Portretten en praktijken uit de geschiedenis van het maatschappelijk werk, Assen: Van Gorcum, 21-38.

Blok, A. (1993), De Bokkerijders, Roversbenden en geheime genootschappen in de Landen van Overmaas (1730-1774), Amsterdam: Prometheus.

Bock, G. (1986), Zwangssterilisation im Nationalsozialismus, Opladen: Westdeutscher Verlag.

Boekholt, P.Th.F.M. en E.P. de Booy (1987), Geschiedenis van de school in Nederland vanaf de middeleeuwen tot aan de huidige tijd, Assen/Maastricht: Van Gorcum.

Bosma, C., Speciaal onderwijs aan moeilijk lerende kinderen in de negentiende eeuw, R. de Groot, H. Menkveld, J.D. van der Ploeg en P.A. de Ruyter (red.) (1987), Handboek Orthopedagogiek, Groningen: Wolters-Noordhoff, 1017.

Bosma, C., Fokke Yntes Kingma (1813-1883), Een vergeten pionier van het speciaal onderwijs aan verstandelijk gehandicapten in Nederland, Tijdschrift voor Orthopedagogiek, jaargang 28 (1989), 348-368.

Bosma, C., Jan Klootsema (1867-1926): een pionier van het speciaal onderwijs aan verstandelijk gehandicapten in Amsterdam, Tijdschrift voor Orthopedagogiek, jaargang 29 (1990), 590-598.

Brants, L. en A. van Gennep (1992), Vijftig jaar tegendraads, een historische schets van het werk van de William Schrikker Stichting, Amsterdam: William Schrikker Stichting. 
Brants, L. (1997), 'Centrale Vereeniging ter Behartiging van de Belangen van

Zwakzinnigen', op de grens tussen zwakzinnigenzorg en psychiatrie 1910-1924, lezing Trimbosinstituut, Utrecht: z.u..

Dekker, J.J.H., The fragile relation between normality and marginality. Marginalization and institutionalization in the history of education, Paedagogica Historica, jaargang 26 (1990) nr. 2, 13-29.

Dercksen, A. en L. Verplanke (1987), Geschiedenis van de onmaatschappelijkheidsbestrijding in Nederland 1914-1970, Meppel/Amsterdam: Boom.

Donzelot, J. (1977), La police des familles, Paris: Les Éditions de Minuit.

Elias, N. (1987), Het civilisatieproces, sociogenetische en psychogenetische onderzoekingen, Utrecht: Aula.

Foucault, M. (1989), Geschiedenis van de waanzin, Meppel /Amsterdam: Boom.

Ganssmüller, C. (1987), Die Erbgesundheitspolitik des Dritten Reiches, Keulen/Wenen: Böhlau Verlag.

Gennep, A. van (1977), Debiliteit en maatschappelijke ongelijkheid, de mythe van het moeilijk lerende kind, Meppel/Amsterdam: Boom.

Gennep, A. van (1980), Naar een kritische orthopedagogiek, Meppel/Amsterdam: Boom.

Gennep, A. van (1981), Begaafdheid, een hoofdstuk uit de (ortho)pedagogische mythologie, Meppel / Amsterdam: Boom.

Gennep, A. van, Verschuivingen in de zwakzinnigenzorg, in: Doornbos, K., C. van Rijsbergen en A. van Veen (1988), Verschuivingen in orthopedagogische werkvelden, Amsterdam/ Lisse: Swets en Zeitlinger, 47-69.

Goei, L. de (2001), De psychohygiënisten, Psychiaters, cultuurkritiek en de beweging voor geestelijke volksgezondheid in Nederland, 1924-1970, Nijmegen: SUN.

Graas, D. (1996), Zorgenkinderen op school, Geschiedenis van het speciaal Onderwijs in Nederland, 1900-1950, Leuven-Apeldoorn: Garant.

Grinten, T. van der (1987), De vorming van de ambulante geestelijke gezondheidszorg, een historisch beleidsonderzoek, Baarn: Ambo.

Hamer, T. [1965], Sociaal-pedagogische zorg in het algemeen en die van Amsterdam in het bijzonder, Amsterdam: z.u..

Heerma van Voss, A.J., Querido, een levensverhaal, Maandblad Geestelijke Volksgezondheid, jaargang 46 (1991) $\mathrm{nr} .7 / 8,722-811$.

Hermand, H., 'Geplaagd en onbegrepen'. De arbeidspositie van de 'geestelijk onvolwaardigen' in het interbellum, Maandblad Geestelijke Volksgezondheid, jaargang 56 (2001) $\mathrm{nr}$. 7/8, 659-675.

Hofstee, E.J. (1987), TBR en TBS, De TBR in rechtshistorisch perspectief, Arnhem: Gouda Quint.

Idsinga, T. (1986), Zonnestraal, een nieuwe tijd lag in het verschiet, geschiedenis van een sociaal en architectonisch monument, Amsterdam: De arbeiderspers/stichting wonen.

Israëls, H. en A. Mooij (2001), Aan de Achtergracht, Honderd jaar GG \& GD Amsterdam, Amsterdam: Bert Bakker.

Jak, Th. (1988), Armen van geest, hoofdstukken uit de geschiedenis van de Nederlandse zwakzinnigenzorg, Amsterdam: Pedagogisch Adviesbureau.

Jak, Th.(1993), Huizen van Barmhartigheid, zorg voor zwakzinnigen in Nederland in de tweede helft van de negentiende eeuw, met bijzondere aandacht voor's Heeren Loo, Amersfoort: Vereniging 's Heeren Loo.

Janssen, E.F.M., De opkomst van schoolartsen in Nederland tussen 1895 en 1920 , Pedagogisch Tijdschrift, jaargang 15 (1990), 76-84.

Jong, L. de (1969), Het Koninkrijk der Nederlanden in de Tweede Wereldoorlog 1939-1945, deel I, Voorspel, Amsterdam: Rijksinstituut voor Oorlogsdocumentatie.. 
Jong, L. de (1972), Het Koninkrijk der Nederlanden in de Tweede Wereldoorlog 1939-1945, deel 4, mei '40 - maart '41, Amsterdam: Staatsuitgeverij.

Jong, L. de (1974), Het Koninkrijk der Nederlanden in de Tweede Wereldoorlog 1939-1945, deel 5, maart '41 - juli '42, 's-Gravenhage: Staatsuitgeverij.

Jong, L. de (1976), Het Koninkrijk der Nederlanden in de Tweede Wereldoorlog 1939-1945, deel 7, mei '43 - juni '44, 's-Gravenhage: Staatsuitgeverij.

Jong, L. de (1980), Het Koninkrijk der Nederlanden in de Tweede Wereldoorlog 1939-1945, deel 10a, het laatste jaar I, 's-Gravenhage: Staatsuitgeverij.

Jong, L. de (1990), De bezetting na 50 jaar, 's-Gravenhage: SDU.

L. Kanner (1977), Geschiedenis van de zwakzinnigenzorg en zwakzinnigenonderzoek, Lochem: De Tijdstroom.

Kingma, T. e.a. (1984), Nederlandse Vereniging voor Sociaal Pedagogische Zorg 1932-1982, Jubileumboek ter gelegenheid van het 50 -jarig bestaan, 's Gravenhage: Nederlandse Vereniging voor Sociaal Pedagogische Zorg.

Klijn, A. (1995), Tussen caritas en psychiatrie, lotgevallen van zwakzinnigen in Limburg 1879-1952, Hilversum: Verloren.

Koldam, W.E. van (1987), 75 jaar Vereniging Zwakzinnigenzorg te Groningen, 1913 - 1 maart - 1988, Groningen: Vereniging Zwakzinnigenzorg.

Leeuwen, J. van (1993), Meester Frantsens ideeën verwezenlijkt, de ontwikkeling van de zorg voor geestelijk gehandicapten in Vlaardingen, Vlaardingen: Herman Frantsenstichting.

Mans, I. (1998), Zin der Zotheid, vijf eeuwen cultuurgeschiedenis van zotten, onnozelen en zwakzinnigen, Amsterdam: Bert Bakker.

Noordman, J.(1989), Om de kwaliteit van het nageslacht, Eugenetica in Nederland 1900-1950, Nijmegen: SUN.

Nijnatten, C. van (1986), Moeder Justitia en haar kinderen, de ontwikkeling van het psycho-juridische complex in de kinderbescherming, Lisse: Swets \& Zeitlinger.

Oosterhuis, H. (2003), Insanity and other discomforts, a century of extramural psychiatry and mental health care in the Netherlands 1900-2000, Maastricht: bijdrage International Workshop Cultures of Psychiatry and Mental Health Care in the Twentieth Century: Comparisons and Approaches.

Querido, A. (1948), De nazorg voor het Buitengewone Onderwijs te Amsterdam, plaats, taak en werkwijze, Amsterdam: GG\&GD en AGO.

Ploeg, R. van der en R. Zinkstok (1986), Wij zijn allen werklieden, de opkomst van de moderne arbeidsmoraal in de negentiende eeuw, Baarn: Ambo.

Regt, A. de (1984), Arbeidersgezinnen en beschavingsarbeid, Ontwikkelingen in Nederland 1870-1940; een historisch-sociologische studie, Meppel/Amsterdam: Boom.

Rooy, P. de (1979), Werklozenzorg en werkloosheidsbestrijding 1917-1940, Landelijk en Amsterdams beleid, Amsterdam: Van Gennep.

Rose, N. (1985), The Psychological Complex, Psychology, Politics and Society in England 1869-1939, Londen: Routledge \& Kegan Paul.

Scheerenberger, R.C. (1983), A History of Mental Retardation, Baltimore/Londen: Paul H. Brookes Publishing Co..

Schepper, R.M. de (1991), De Pameijer Stichting (1926-1991), een geschiedenis van de sociale psychiatrie en verstandelijk-gehandicaptenzorg te Rotterdam, Rotterdam: Pameyer Stichting.

Schuursma, R. (2000), Jaren van opgang, Nederland 200-1930, z.p. (Balans).

Stel, J.C. van der (1995), Drinken, drank en dronkenschap, Vijf eeuwen drankbestrijding en alcoholhulpverlening in Nederland, Hilversum: Verloren.

Stuurman, S. (1983), Verzuiling, Kapitalisme en Patriarchaat, Nijmegen: SUN.

Sijes, B.A. (1990), De arbeidsinzet, De gedwongen arbeid van Nederlanders in Duitsland 1940-1945, 's-Gravenhage: SDU uitgeverij. 
Veld, Th. (1987), Volksonderwijs en leerplicht; een historisch sociologisch onderzoek naar het ontstaan van de nederlandse leerplicht 1860-1900, Delft: Eburon.

(wet) sociale werkvoorziening (z.j.), Rijswijk: Nationaal Overlegorgaan Sociale werkvoorziening.

Werlinder, H. (1978), Psychopathy: A History of the Concepts. Analysis of the origin and development of a family of concepts in psychopathology, Uppsala: Acta Universitatis Upsaliensis.

Willemse, T.R.M., Jan Klootsema (1867-1926), architect van de residentiële orthopedagogiek, R. de Groot, H. Menkveld, J.D. van der Ploeg en P.A. de Ruyter (red.) (1987), Handboek Orthopedagogiek, Groningen: Wolters-Noordhoff, 1026.

Willemsen, C. (2001), De belofte van het hiernumaals, Zeventig jaar ambulante geestelijke gezondheidszorg in het gewest Breda, Nijmegen: SUN.

Wilmink, A.J., prof, dr. I.C. van Houte, 6 juli 1891-17 november 1989, Tijdschrift voor Orthopedagogiek, jaargang 28 (1989), 567-568. 


\section{Persoonsregister}

André 83.

Bartels, C.J. 21, 183.

Beek, van 144, 166.

Bemmelen, M.J.M. van 128, 129.

Bierens de Haan, P. 22.

Binet 28, 44, 86, 171.

Blok, A. 15.

Bodaan, L. 95, 131, 139, 140, 159.

Boer, P. de 11, 46, 47, 48, 49, $50,51,52,53,56,58,64,65$, $66,68,69,70,71,73,74,79$, $80,82,83,84,85,86,87,88$, $89,91,99,100,101,105,106$, $107,109,110,111,126,127$, $129,130,133,134,137,138$, $139,140,141,143,144,145$, $146,147,150,151,152,153$, $154,155,156,157,163,164$, $165,166,167,168,170,171$, 173, 174, 177, 181, 185.

Bouman, K.H. 10, 45, 77, 163 , 180, 186.

Bouman, L. 34.

Boorsma 40, 42.

Bruijn, T. 45.

Burt, C. 128.

Calliber, A.J.30, 81.

Carp, E.A.D.E. 130.

Carstens, L.C. 133.

Christ, G.A.E. 142, 154.

Colijn, H. 113.

Denneboom, J. 84.

Det, E.J. van 50, 152.

Detiger, W.F. 78, 79, 125, 148, $150,154,165,166$.

Donzelot, J. 13.

Douglas Turner, F. 120, 121.

Dugdale 183.
Dijk, G.H. van 131, 157, 159, $160,164,165,166,167,168$, $170,182$.

Elias, N. 12, 14.

Fernald, W.E. 183.

Fortanier, A.H. 127.

Frantsen, H. 73, 90, 91, 99, 108, $139,170,177,180$.

Gewin, J. 41.

Goddard, H.H. 27, 44, 121, 183.

Gottschick, J. 116.

Graas, D. 9, 16.

Grootenboer, G.M. 76.

Grootjans 133.

H.E. $81,83$.

Haan, C. de 32.

Hendrik, Prins 80.

Herderschêe, D. 27, 28, 41, 44, $45,50,51,52,74,75,86,118$, $119,120,121,123,125,171$.

Heijermans, L. 50, 52, 53, 74, 78.

Hiemstra, S. 55, 63.

Houte, I.C. van 155, 162, 163 , 168.

Houten, van 24.

Jacobs, H.J. 143.

Jak, Th. 9, 16.

Jan Baptist, broeder 135.

Jeu, de 154.

Kingma, F.Y. 20, 26.

Klijn, A. 9, 16.

Klootsema, J. 19, 20, 22, 87, 129.

Koenen, J.H.M. 117, 127.

Koetsveld, van 19.

Köhler, D. 20, 26, 29, 32.

Koning, G. 151.

Kortenhorst, C.T. 123.

Kraepelin, E. 22.

Kuyper, A. 20, 27.

Leeflang, C. 5, 110, 111, 132, 133. 
Lewis, E.O. 121.

M. $\mathrm{Ph}$., frater 116.

Mans, I. 9, 16.

Mesdag, S. van 33.

Mesen, van 142.

Meijers, F.S. 34, 45, 50, 52, 53, $71,74,77,78,90,124,146$, 181.

Majoie, H.J.M. 101, 102, 134, 136, 142, 158, 172.

Marx, K. 13.

Nagtzaam 46.

Pameyer, J.H. 77, 144.

Paauw, de 147.

Pius XI, paus 116.

Ploeg, G.J. van der 28, 113, 131, 144, 145.

Polderman, J. 120.

Potters, Th. J. 94, 133, 144.

Querido, A. 78, 124, 125, 142, 145.

Rost van Tonningen, M.M. 168.

Scheer, W.M. van der 36 .

Schermerhorn 97.

Scholz, L. 88, 129.

Schuyt, E.P. 70, 71, 108, 110, $134,137,139,141,147,149$, $154,156,159,164,165,166$, $170,177$.

Schreuder, A.J. 33, 34, 75.

Schreuder, J. 40.

Schreuder, P.G. 93.

Schreuder, P.H. 34, 93, 111, 117.

Schrijver, F. 122.

Schuurmans Stekhoven. J.H. 21, $37,56,68,69$.

Simon 28, 44, 86, 171.

Slot, dr. 22.

Toledo, van 133.

Troelstra, P.J. 74.

Visser, C. 56, 64, 111.

Visser. Fr. 34, 122, 123, 128 , 173.
Voorthuijsen, A. van 22, 33, 46, $49,69,73,74,75,77,92,94$, $108,109,119,120,121,122$, $126,134,136,140,143,153$, $155,160,161,162,186$.

Vos, C.J. 110, 111.

Wepster, A.H.D. $35,36,47,73$, $80,95,101,108,112,127,139$, $141,144,145,153,157,166$, $169,170,174,177,178$,

Werkhoven, H. 93, 139, 146, 166, $170,177$.

Westerveld 153.

Wiersma, D. 130.

Willeboer 131, 153.

Willemsen, Th. 81.

Wouden, J.J.C. van der 89, 91 , 92, 95, 104, 139, 146, 170, 177. Wijhe, M. van 19, 20, 26. 


\section{Summary}

The history of Dutch extramural care for people with a minor mental handicap between 1900 en 1945 cannot be separated from the origins of special education for mentally handicapped children, of which this care was seen as a follow-up. Therefore it was called 'after-care'.

Special primary education (BLO) and after-care started in a period in history when the image of mentally handicapped people was very negative, influenced by eugenic ideas that implied, amongst others things, that the feeble-minded were naturally inclined towards crime, alcoholism and prostitution because of their genetic make-up. There was a tension between eugenics on one side, which pessimistically assumed that the unwanted behaviour of the feeble-minded was hereditary and could not be changed in one generation, and the optimistic, positivistic attitude of heo-hygienism on the other side, which believed in the power of therapy an pedagogics.

People inclined towards eugenics stated that the only way to deal with the feeble-minded was to remove them from society and possibly prevent their procreation. On the other hand, the neo-hygienists stated that the risks of feebleminded living in society could be decreased to an acceptable level by means of special education and support in society.

The first forms of aftercare were created just after 1900, when BLO-pupils started to leave school in substantial numbers. They were monitored consientiously. The right of existence of BLO depended on the question, if former BLO-pupils were capable of living independently in society or not. The first results showed, that about one-third of them were able to manage indeed. The others, however, needed support. Their former teachers in BLO tried to provide that for them. They tried to find work for them and supported them when asked. But as time progressed, more and more pupils left BLO and the task grew to big for the teachers. They no longer could give adequate support.

In 1905 a test started in The Hague with support of volunteers. In 1913 a test started in Rotterdam with supplemental education. Both tests failed. A third test was held in the town of Dordrecht. The head of the local school for BLO, Adriaan Wepster, had to deal with several former pupils who where not suited for paid employment. He started up a small special workshop in which they could do adapted work in sheltered conditions. This test succeeded. The sheltered employment, which Wepster started in 1917, would be copied all over the Netherlands.

In Amsterdam a report was published in 1917, which dealt with the question of how the support of former BLO-pupils should take shape. The conclusion of this report, that became known as the 'Aftercarereport', was that it could best be given by a professional worker, a 'civil servant for social care', who would only deal with former BLO-pupils.

This first professional worker, Pier de Boer, was appointed in June 1921. In the next eighteen months he initiated a methodology that centred around work. By means of intensive support De Boer helped his pupils to acquire and retain paid employment. 
In Haarlem, the next Dutch town that considered professional aftercare, De Boer was asked to become president of a commission thad had to advise the town council in this matter. The commision wrote the 'Haarlem aftercarereport, that further developed the methodology of aftercare. This report would become very influential and was a point of reference for aftercare in the next decades.

The Haarlem aftercarereport described the components aftercare should consist of. Its nucleuas was described as 'social care': finding jobs, support after finding a job and intervening when a former BLO-pupil was in trouble of under threat of getting into trouble.All the other parts of aftercare were derived from this core-task. When aftercare-pupils where not capable of doing paid work, then sheltered employment had to be created. In order to be able to control the activities of aftercare-pupils during evening hours, 'evening care' had to be created as well. In 1924, the aftercare in Haarlem became definite with the appointment of a civil servant for aftercare and the opening of a workshop for sheltered employment. Evening care had been taken care of at an earlier stage.

In the second half of the 1920 s another four civil servants for aftercare were appointed in different towns in the Netherlands. Six more workshops for sheltered employment were started as well. Evening care was spread out much wider because it was for the main part joined with the schools for special education.

During this period, the methodology of aftercare was further developed, in which Pier de Boer, the Amsterdam aftercare-worker, played an important role. he focused on what he called 'guidance', which he thought was necessary for former BLO-pupils, to keep their place in society. In his vision, guidance had not as primary goal to protect aftercare pupils from society. They had to learn to deal with the hardships supplied by society in order to be able to accept their modest place inside it.

Most important means of maintaining aftercare pupils in society was either doing paid work or, if this was not possible, working in a sheltered workshop. Only those who were not able to work under any circumstances were allowed to be placed inside an intramural institution.

In the 1930 s, the number of professional aftercare workers and sheltered workshops grew steadily, in spite of the problems caused by the Great Depression. This growth, however, lagged considerably behind the increase of special education in the Netherlands as a whole.

In the same period, for the first time most aftercare workers united in a national organisation, the Dutch Society for Aftercare Special Education (NVNBO). By uniting themselves, the aftercare became an important national player, especially with regards to competitive fields of action such as social psychiatry and the employment for the handicapped.

With respect to development of the methodology of aftercare, there was hardly any change in this period. Main cause for this was probably the enormous amount of energy that the aftercare workers had to put in maintaining their organisations under the difficult circumstances of the depression. In this period, eugenic thinking became more influential. For the first time, attempt were made to test eugenic propositions by means of research. 
The involvement of the Netherlands in World War II meant that aftercare workers had to do their utmost to maintain their organisations. Moreover, the dramatic deterioration of social circumstances during the German occupation led to the aftercare workers becoming very anxious that their pupils would slip into a mass-lapse. This led to the workers extending their support of (forced) residential care, on a scale that was unimaginable during the $1930 \mathrm{~s}$.

The attitude of the aftercare workers towards the national-socialistic occupation of the country was in some ways naive. It was deemed unimaginably that the fascist ideology could in any way be dangerous to the mentally handicapped. So much so, that in the early years of the occupation a national register for current and former BLO-pupils was compiled. When the occupier wanted to gain access tot this register at the beginning of 1944, the only way to avoid this was to destroy it.

The tension between neo-hygienism and eugenics with regards to the feebleminded continually played an important role in the first part of the twentieth century. The aftercare-workers showed, through their work, that the eugenicists were wrong. They proved that with proper guidance, a large proportion of the former BLO-pupils were able to function adequately in society and even contribute to the well-being of society as a whole. By doing so, the aftercare workers contributed to a change of image that existed in society about the feeble-minded in a positive way, a development that was further expanded in the years after Word War II. 


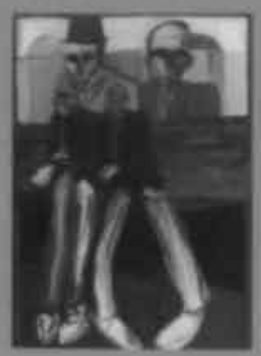

In 1917 ging in Nederland een nieuwe professionele vorm van hulpverlening van start, die zich specifiek richtte op mensen met een lichte verstandelijke handicap. Deze 'nazorg' was in de jaren voor en tijdens de tweede wereldoorlog nauw verbonden met het Buitengewoon Lager Onderwijs, dat zich op dezelfde doelgroep richtte. De nazorg zag zichzelf, zoals de naam al zegt, als een vervolg op het speciale onderwijs voor deze groep kinderen. In deze publicatie wordt het ontstaan van deze specifieke vorm van hulpverlening beschreven en het hoe en waarom van de keuzes die daarbinnen gemaakt werden. Waarom werd er, bijvoorbeeld, gekozen voor hulp in de maatschappij, in plaats van segregatie, zoals in enkele ons omringende landen gebeurde? En waarom werd zo zwaar de nadruk gelegd op het belang van het verrichten van arbeid? Deze studie geeft inzicht in de bronnen van de maatschappelijke hulp aan mensen met een verstandelijke handicap, die aanvankelijk wortelden in de filantropische hulpverlening van de negentiende eeuw maar die zich in de loop der jaren ontwikkelde tot een zelfstandige, professionele discipline die zich een plaats wist te verwerven in het brede hulpverleningsveld. Belangrijk daarbij was vooral de Amsterdamse Nazorgambtenaar Pier de Boer (1889-1945), die als pionier zowel inhoudelijk als praktisch aan de wieg van de maatschappelijke hulp aan mensen met een lichte verstandelijke handicap in Nederland heeft gestaan.

Luc Brants studeerde culturele antropologie aan de Katholieke Universiteit Nijmegen. Hij was werkzaam als begeleider van Alleenstaande Minderjarige Asielzoekers en later als coördinator van VluchtelingenWerk op een asielzoekerscentrum. Sinds eind 2003 heeft hij een eigen onderzoeksbureau en sinds mei 2004 is hij ook werkzaam als projectleider diversiteitsbeleid in de kinderopvang. Eerder publiceerde hij onder meer, met Ad van Gennep, een studie naar de geschiedenis van de Willem Schrikker Stichting, een jeugdhulpverleningsinstelling voor kinderen met een handicap. 